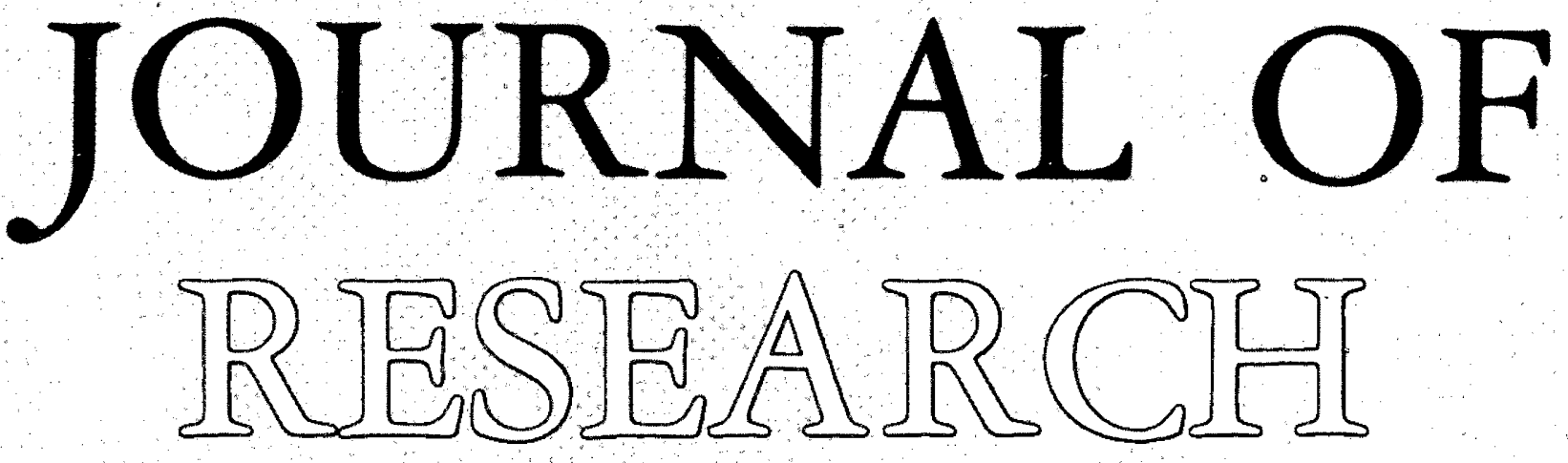

OF THE U.S. GEOLOGICAL SURVEY

Scientific notes and summaries of investigations in geology, bydrology, and related fields

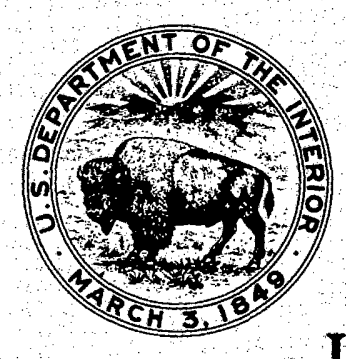

U.S. DEPARTMENT OF THE INTERIOR 


\section{UNITED STATES DEPARTMENT OF THE INTERIOR \\ ROGERS C. B. MORTON, Secretary \\ GEOLOGICAL SURVEY}

V. E. McKelvey, Director

For sale by the Superintendent of Documents, U.S. Government Printing Office, Washington, D.C., 20402. Order by SD Catalog No. JRGS. Annual subscription rate $\$ 8.50$ (plus $\$ 2.25$ for foreign mailing). Single copy $\$ 1.50$. Prices valid until July 1,1973 , at which time a price increase is scheduled. Make checks or money orders payable to the Superintendent of Documents.

Send all subscription inquiries and address changes to the Superintendent of Documents at the above address.

Purchase orders should not be sent to the U.S. Geological Survey library.

Library of Congress Card No. $72-600241$
The Journal of Research consists of six issues a year (January-February, MarchApril, May-June, July-August, SeptemberOctober, November-December) published in Washington, D.C., by the U.S. Geological Survey. It contains papers by members of the Geological Survey on geologic, hydrologic, topographic, and other scientific and technical subjects.

The Journal supersedes the short-papers chapters (B, C, and D) of the former Geological Survey Research ("Annual Review") series of professional papers. The synopsis chapter (A) of the former Geological Survey Research series will be published as a separate professional paper each year.

Correspondence and inquiries concerning the Journal (other than subscription inquiries and address changes) should be directed to the Managing Editor, Journal of Research, Publications Division, U.S. Geological Survey, Washington, D.C., 20242.

Papers for the Journal should be submitted through regular Division publication channels.

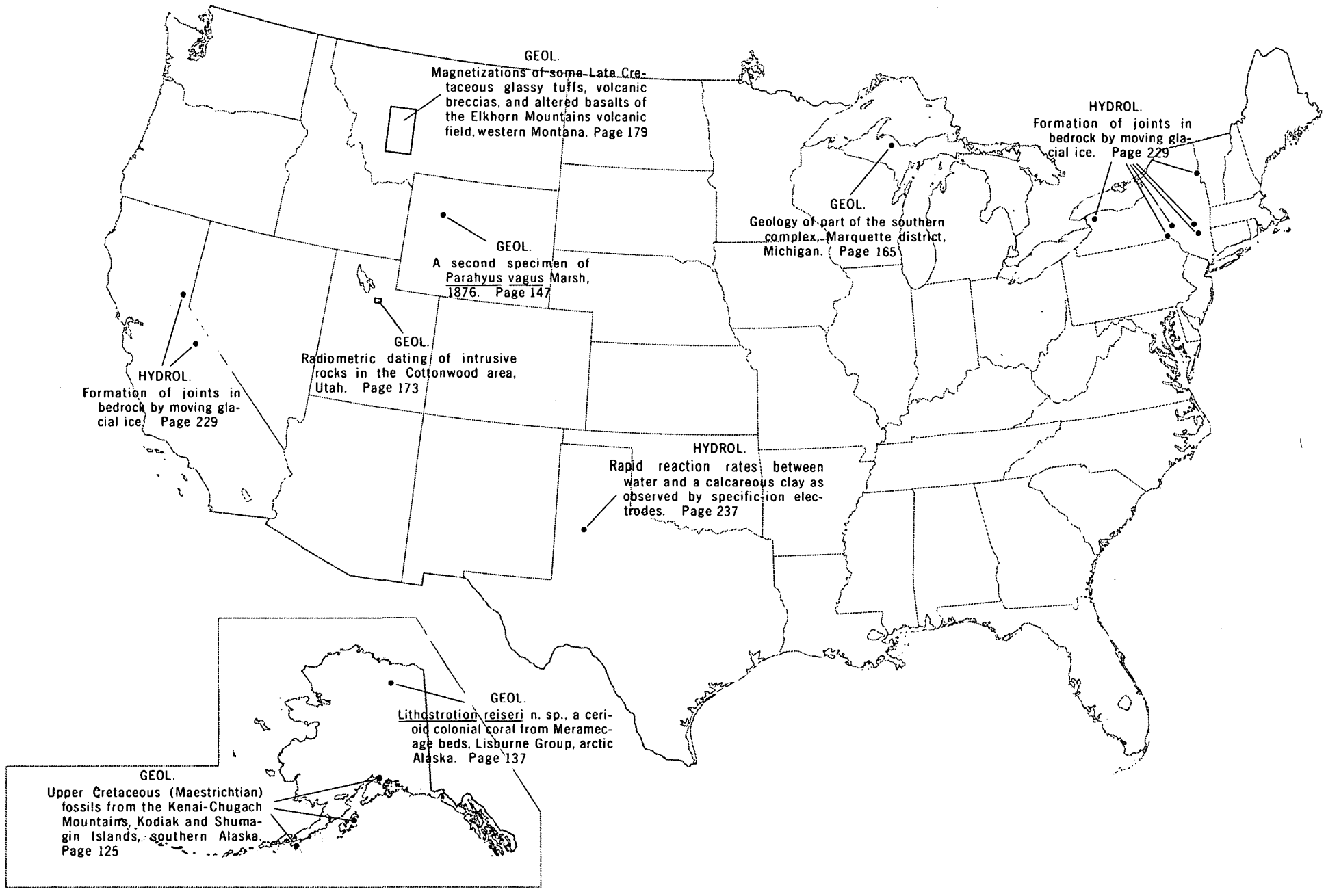

The Secretary of the Interior has determined that the publication of this periodical is necessary in the transaction of the public business required by law of this Department. Use of funds for printing this periodical has been approved by the Director of the Office of Management and Budget through February 11, 1975.

\section{GEOGRAPHIC INDEX TO ARTICLES}

[See Contents for articles concerning areas outside the United States and articles without geographic orientation] 


\title{
JOURNAL OF RESEARCH

\author{
of the
}

\author{
U.S. Geological Survey
}

Vol. 1 No. 2

Mar.-Apr. 1973

\section{CONTENTS}

Abbreviations .

\section{GEOLOGIC STUDIES}

Upper Cretaceous (Maestrichtian) fossils from the Kenai-Chugach Mountains, Kodiak and Shumagin Islands,

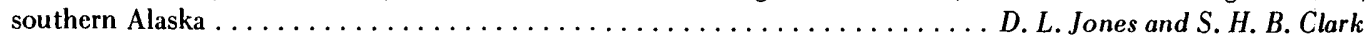
Lithostrotion reiseri n. sp., a cerioid colonial coral from Meramec-age beds, Lisburne Group, arctic Alaska . . . . . $\ldots \ldots \ldots \ldots \ldots \ldots \ldots \ldots \ldots \ldots \ldots \ldots \ldots \ldots \ldots \ldots \ldots \ldots \ldots \ldots \ldots \ldots \ldots \ldots$ Armstrong

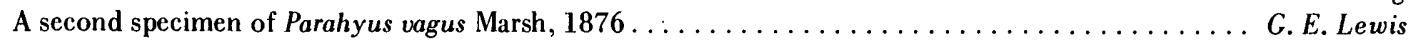

The concept of growth and maturity of ore-stage pyrite in roll-type uranium deposits $\ldots \ldots \ldots \ldots \ldots \ldots$ $\ldots \ldots \ldots \ldots \ldots \ldots \ldots \ldots \ldots \ldots \ldots \ldots \ldots \ldots \ldots \ldots \ldots \ldots \ldots \ldots$. Warren and H. C. Granger

Age and tectonic implications of some low-grade metamorphic rocks from the Yucatan Channel............ $\ldots \ldots \ldots \ldots \ldots \ldots \ldots \ldots \ldots \ldots \ldots \ldots \ldots \ldots$. G. Vedder, N. S. MacLeod, M. A. Lanphere, and W. P. Dillon

Geology of part of the southern complex, Marquette district, Michigan .....W. F. Cannon and G. C. Simmons

Radiometric dating of intrusive rocks in the Cottonwood area, Utah . . . . . . . . . . . . . . . . $\ldots \ldots \ldots \ldots \ldots \ldots \ldots \ldots \ldots \ldots \ldots \ldots$. Crittenden, Jr., J. S. Stuckless, R. W. Kistler, and T. W. Stern

Magnetizations of some Late Cretaceous glassy tuffs, volcanic breccias, and altered basalts of the Elkhorn

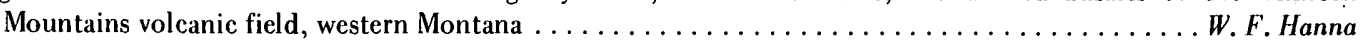

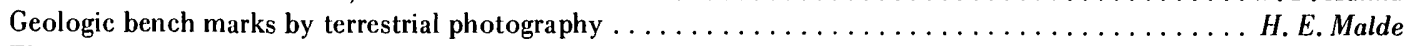

The microgravimetric determination of acid-insoluble impurities in the complete analysis of small samples of acid-soluble minerals $\ldots \ldots \ldots \ldots \ldots \ldots \ldots \ldots \ldots \ldots \ldots \ldots \ldots \ldots$ Meyrowitz

Effects of laboratory treatments on silver and other elements in native gold $\ldots \ldots \ldots \ldots \ldots$ $\ldots \ldots \ldots \ldots \ldots \ldots \ldots \ldots \ldots \ldots \ldots \ldots \ldots \ldots \ldots \ldots \ldots$. Campbell, E. L. Mosier, and J. C. Antweiler

A precautionary note on the use of mixed solvents in soxhlet extraction procedures $\ldots \ldots \ldots \ldots \ldots \ldots$ $\ldots \ldots \ldots \ldots \ldots \ldots \ldots \ldots \ldots \ldots \ldots \ldots \ldots \ldots \ldots \ldots \ldots \ldots \ldots \ldots \ldots \ldots \ldots \ldots$ Roberts and J. G. Palacas

\section{TOPOGRAPHIC STUDIES}

Photomechanical experiments in automated cartography

C. R. Gilman

\section{HYDROLOGIC STUDIES}

Formation of joints in bedrock by moving glacial ice

F. W. Trainer

Rapid reaction rates between water and a calcareous clay as observed by specific-ion electrodes $\ldots \ldots W$. W. Wood

Hydraulic sand-model studies of miscible-fluid flow J. M. Cahill 
ABBREVIATIONS

[Singular and plural forms for abbreviations of units of measure are the same]
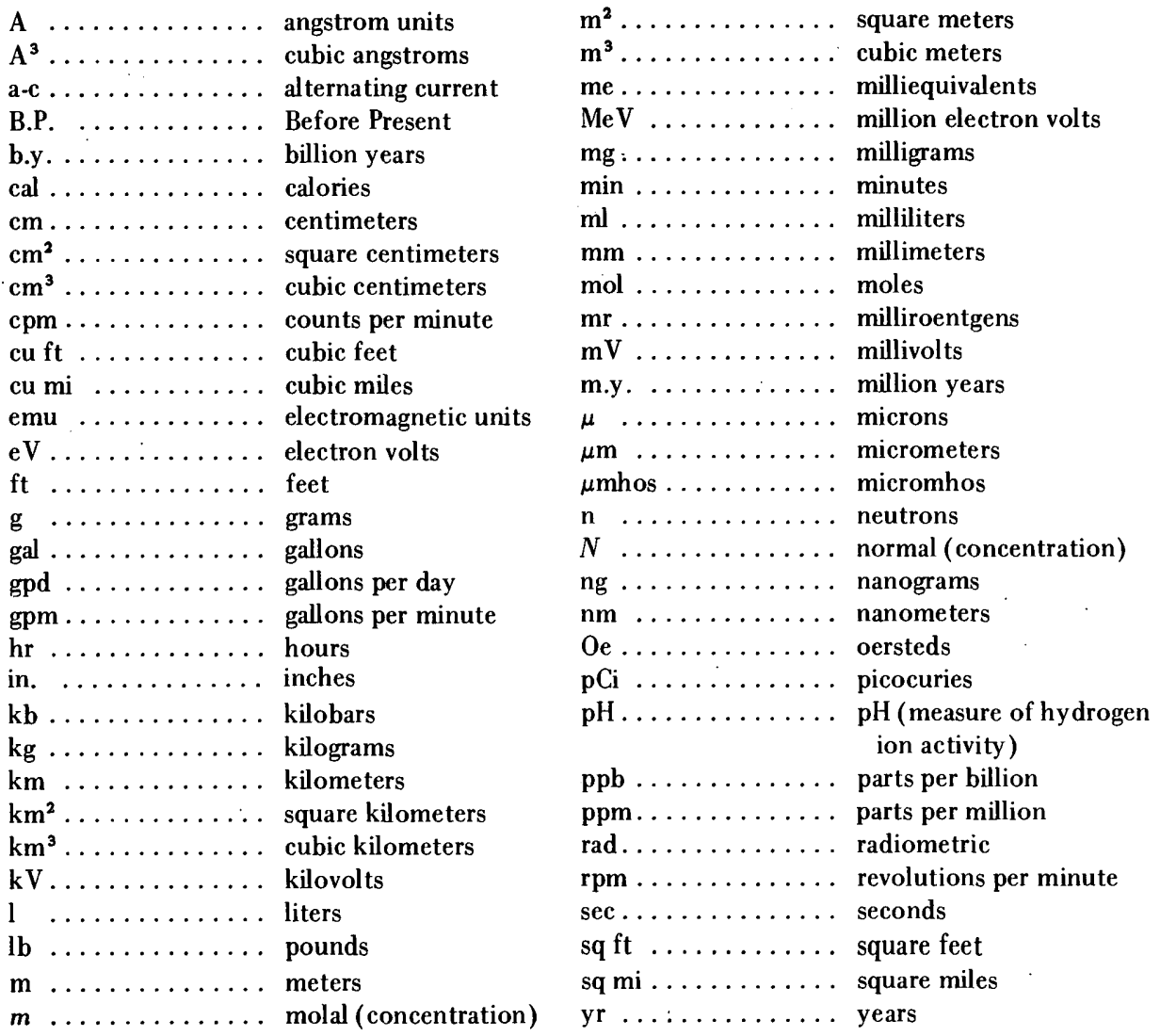


\title{
UPPER CRETACEOUS (MAESTRICHTIAN) FOSSILS FROM THE KENAI-CHUGACH MOUNTAINS, KODIAK AND SHUMAGIN ISLANDS, SOUTHERN ALASKA
}

\author{
By DAVID L. JONES and SANDRA H. B. CLARK, \\ Menlo Park, Calif.
}

\begin{abstract}
A thick sequence of highly deformed flyschlike metasandstone, slate, and argillite crops out in southern Alaska in the Kenai-Chugach Mountains and on Kodiak and the Shumagin Islands to the southwest. These poorly fossiliferous rocks have long been considered Cretaceous in age because of scattered occurrences of fragmentary shells of Inoceramus. Mainly on the basis of new fossil collections, the age of some of these rocks can now be firmly established as Late Cretaceous (Maestrichtian); the critical fossil is Inoceramus kusiroensis Nagao and Matsumoto. Inoceramus kusiroensis also occurs in the much more fossiliferous and only slightly deformed Matanuska Formation that forms a parallel belt north of the Chugach Mountains. On the basis of faunal, lithologic, and bedding characteristics, the Matanuska Formation is the shelf equivalent of the deepwater, trench, or continental-rise deposits of the Kenai-Chugach Mountains and islands to the southwest. "Inoceramya concentrica" Ulrich occurs with Inoceramus kusiroensis and is Maestrichtian in age, not Early Jurassic as E. O. Ulich suggested in 1910. The syntypes of $I$. concentrica are refigured and a lectotype is designated.
\end{abstract}

A thick sequence of Mesozoic metasandstone, slate, and argillite is exposed in an arcuate belt near the Pacific Coast in southern Alaska (fig. 1). These rocks, which are many thousands of feet thick, complexly deformed, and poorly fossiliferous, have long been considered to be Cretaceous, but firm evidence for their age has hiterto not been published. The purpose of this report is to describe and illustrate Upper Cretaceous fossils, mainly collected within the past 2 or 3 years, that permit close dating of some of these rocks. Descriptions of fossil localities are given in table 1 on page 135.

\section{REGIONAL GEOLOGY}

Sedimentary rocks of the Chugach and Kenai Mountains in southern Alaska and islands along the strike to the southwest include the Valdez Group, named for exposures near Valdez in Prince William Sound (Schrader, 1900; Moffit, 1954), similar rocks (Valdez? Group) widely and well exposed near Anchorage (Clark, 1972a, b), the Kodiak Formation of Kodiak Island (Moore, 1969), and the Shumagin Formation of Burk (1965) of the Shumagin Islands and Sanak Island (Moore, 1972). These formations are grossly similar in lithology, bedding characteristics, age, and depositional environment. They differ markedly from nearby highly fossiliferous and only slightly deformed Cretaceous rocks that occur to the north in the Wrangell Mountains, Talkeetna Mountains, Matanuska Valley, and Alaska Peninsula.

Despite the general similarity of rocks and structures in the Kenai-Chugach Mountains and on islands to the southwest, there is no name in general use that embraces the rocks in all these localities. This lack, together with the recent proliferation of local formational names and uncertainties in correlation, makes discussion of the entire belt cumbersome. Payne (1955) included the rocks of the Kenai and Chugach Mountains and Kodiak Island in the Chugach Mountains geosyncline. Similar rocks from the Shumagin Islands were placed in the Shumagin Shelf unit. Moore (1972) referred to these rocks as "Cretaceous trench sediments," which they may be, but general use of a genetic term such as "trench" seems unwarranted. Berg and others (1972) have referred to these rocks as the "Chugach terrane," here accepted as the most useful informal name applicable to the entire belt of highly deformed upper Mesozoic rocks of coastal southern Alaska.

On the basis of detailed mapping in the Chugach Mountains near Anchorage, Clark (1972b) subdivided the upper Mesozoic rocks into a heterogeneous assemblage of metavolcanic and metaclastic rocks of presumed Late Jurassic and (or) Cretaceous age named the McHugh Complex and a structurally lower sparsely fossiliferous flysch deposit termed the Valdez(?) Group (fig. 2).

Rocks of the Valdez(?) Group comprise very thick sequences of rhythmically interbedded metasandstone (mostly metagraywacke) and argillite that alternate with thick, massive beds of metasandstone and rare beds of conglomeratic argillite. Small-scale sedimentary structures in these rocks include graded bedding, small-scale crossbedding, flame structures, convolute laminations, and disturbed bedding. Sole markings are difficult to observe because of shearing along the base of the beds, altheugh on the Shumagin Islands where deformation is less intense, sole markings are abundant and well preserved (Moore, 1972). 


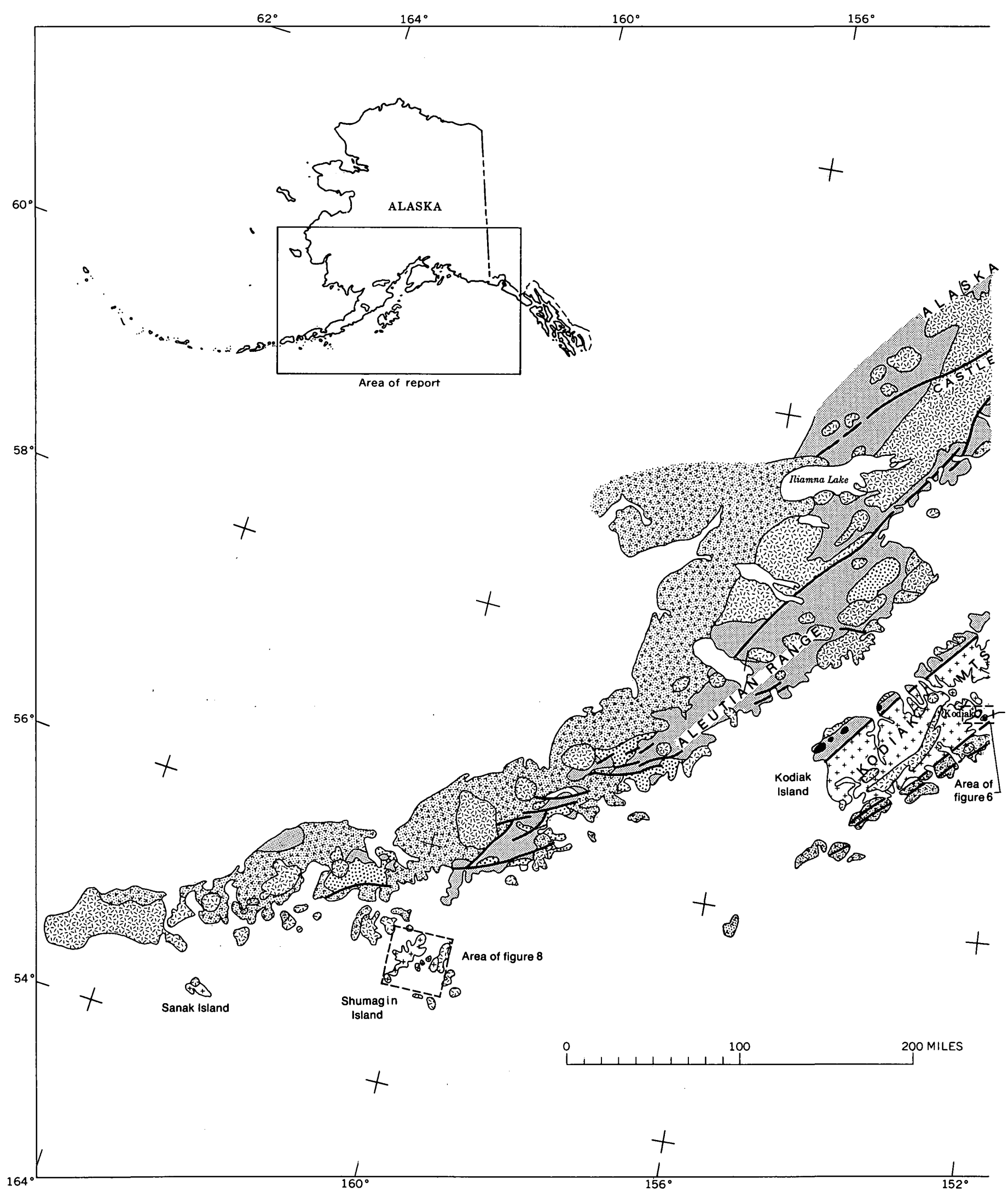

Figure 1.-Map of southern Alaska showing distribution of major geologic elements (modified from King, 1969), fossil localities discussed in the text, and locations of figures 2,6 , and 8 . 


$152^{\circ} \quad 148^{\circ} \quad 144^{\circ} \quad 140^{\circ}$
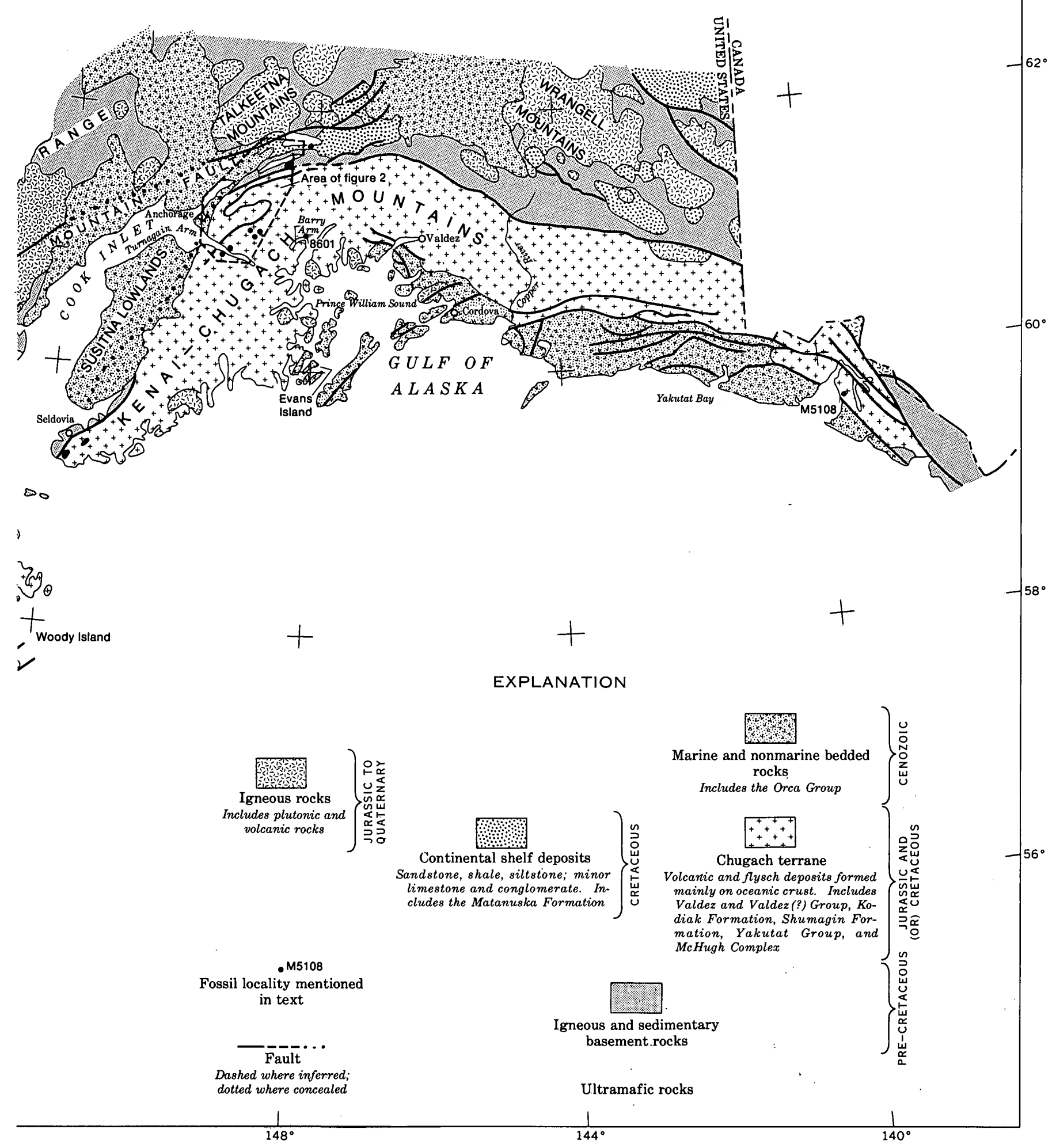

Figure 1. 


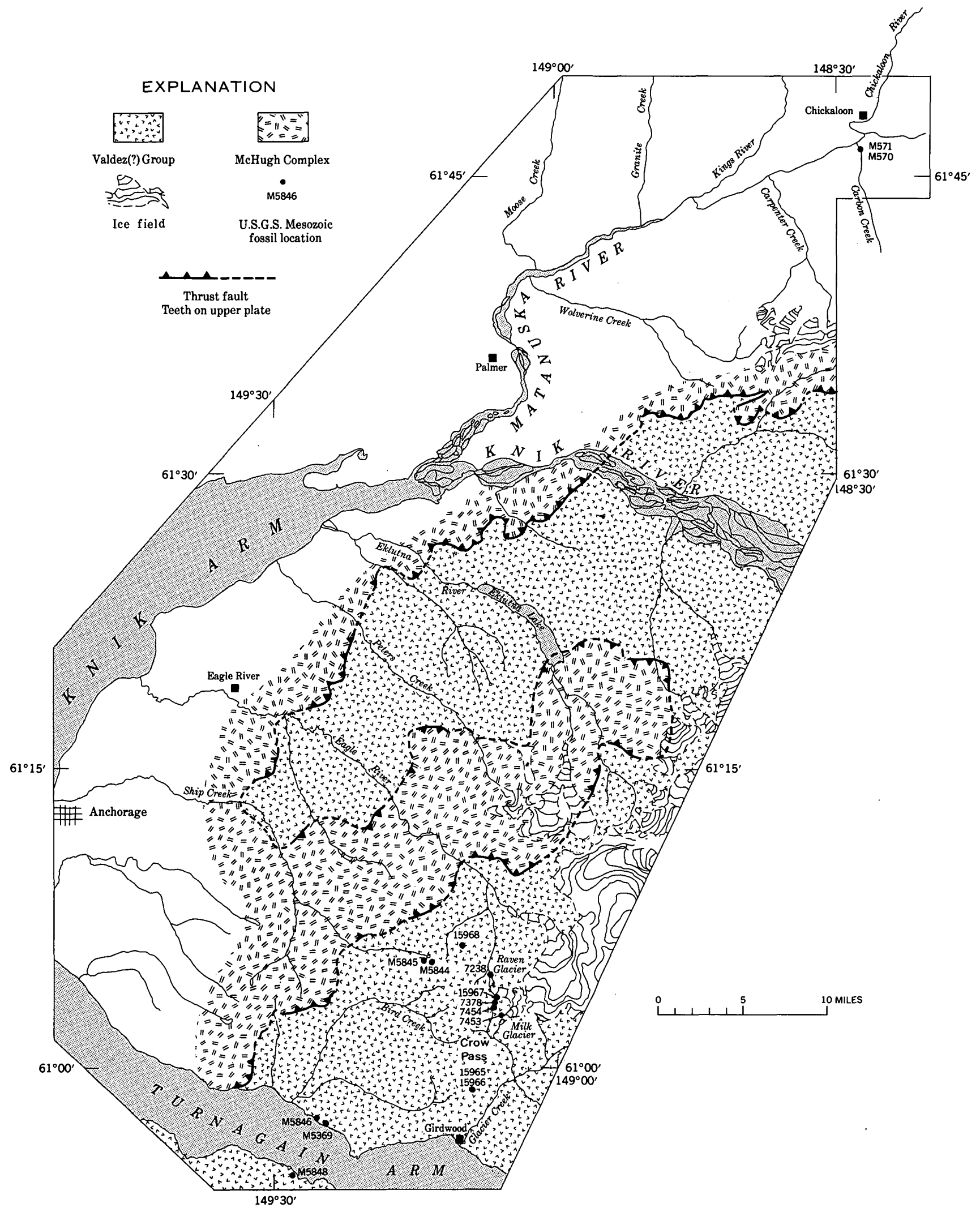

Figure 2.-Map of Anchorage-Turnagain Arm area, showing distribution of the Valdez(?) Group, McHugh Complex, and location of fossil localities described in text. 
Fossils are very scarce in the Valdez(?) Group and related rocks, and many stratigraphic sequences thousands of feet thick fail to show even traces of organisms. In a few places bedding surfaces are covered with fossil "hash" composed of broken fragments and rare but nearly complete specimens of Inoceramus. Although these fossils have been known for many years (Martin, 1926; Park, 1933; Imlay and Reeside, 1954), it has only been within the past few years that specimens well-enough preserved to permit reliable identification have been found. The Valdez(?) Group near Anchorage is highly deformed, and the rocks have been metamorphosed to lower greenschist facies. Tight similar folds predominate with welldeveloped axial-plane slaty cleavage. The folds generally trend north-northeast and axial surfaces dip steeply northwest or southeast. In some areas the rocks are phyllitic and have undergone two periods of folding, for previously formed cleavage or schistosity is itself folded around steeply plunging axes.

Such highly deformed rocks offer poor opportunity for finding fossils as they tend to part along planes of cleavage or schistosity and not along bedding planes where the fossils are concentrated.

\section{FOSSILS FROM THE CHUGACH TERRANE OF SOUTHERN ALASKA}

The first molluscan fossils discovered in rocks of the Chugach Mountains in southern Alaska and correlative strata to the southwest were found by W. H. Dall in 1895 and described by E. O. Ulrich in 1910 (1910, p. 51, 134, 135; pls. $12,13)$ as Inoceramya concentrica Ulrich, genus and species new. Specimens obtained from Woody Island near Kodiak were believed by Ulrich $(1910$, p. 432$)$ to be a link between late Paleozoic Posidonomya (= Posidonia) and Cretaceous Inoceramus. Because of this presumed evolutionary relation, he suggested an Early Jurassic age.

Since Dall's original discovery of fossils on Woody Island, specimens of Inoceramus have been found near Girdwood on the north side of Turnagain Arm (fig. 2) and on Barry Arm (fig. 1) in the Port Wells district north of Prince William Sound. Concerning the fossils from these three localities, Imlay and Reeside (1954, p. 228) stated, "Curiously, these three areas contain identical species of Inoceramus characterized by bearing radial markings." They also pointed out that on the same slab as the type of Inoceramya concentrica, but not figured by Ulrich, is the radially ribbed species that occurs at Turnagain Arm. Imlay and Reeside (1954, p. 228) believed that both $I$. concentrica and the radially ribbed forms could be matched with Upper Cretaceous species that occur in Utah and Wyoming in the zone of Scaphites binneyi, suggesting a stratigraphic position corresponding to the upper Coniacian or lower Santonian. Following a review of Cretaceous fossils from southern Alaska, Jones (1967, p. 15) questioned this age assignment that was based on comparison with species in another faunal province because similar species were not known to occur in nearby fossiliferous Coniacian strata of the Matanuska Formation, nor had they been recognized in any of the more fossiliferous Cretaceous deposits in Alaska or elsewhere along the Pacific Coast of North America.

Since that time, much better preserved fossils have been found in the Chugach Mountains, identical fossils have been found in the Matanuska Formation, and a Late Cretaceous (Maestrichtian) age can be assigned with considerable confidence. The critical species is Inoceramus kusiroensis Nagao and Matsumoto, previously described from Upper Cretaceous strata of Japan and northeastern U.S.S.R.

Another fossil cited by Imlay and Reeside (1954, p. 228) in support of a Late Cretaceous age for rocks of the Chugach Mountains is a comatulid crinoid found on the west side of Evans Island in the western part of Prince William Sound. According to Plafker (oral commun., 1971), strata on Evans Island belong to the Orca Group, of early Tertiary age. Imlay and Reeside pointed out that this fossil has a long range (Jurassic to Holocene) thus it obviously contributes nothing to solution of the problem of the age of the Mesozoic rocks.

Inoceramus kusiroensis was first described by $\mathrm{Nagao}$ and Matsumoto (1940, p. 56, pl. 22, fig. 4) from Upper Cretaceous deposits of Hokkaido, Japan. The characteristic ornamentation of this species is concentric rings and narrow, sharp radial ribs. The concentric rings are widely spaced in early growth stages, closely spaced during midgrowth stages, and widely spaced again in mature stages $(1940$, p. 56). Radial ribs appear only at midgrowth stage, at about the time of change from widely to narrowly spaced concentric ribs.

The Alaskan specimens show close similarities to the holotype of $I$. kusiroensis, although on some the early concentric ribs are much more widely spaced (fig. $3, h$ ). In this regard, the Alaskan forms are nearly identical to a specimen of I. kusiroensis from the Koryak Range of northeast U.S.S.R. figured by Vereshchagin and others (1965, pl. 63, fig. 2; see fig. $4, e$ of this report for a copy of their photograph). Because Alaskan specimens also show quite a wide range in variation in strength of early concentric ribbing, this minor difference from the holotype is not considered to be significant.

Radial ribs are well developed on the Alaskan specimens, and the reticulate pattern produced by the intersection of the concentric and radial ornamentation is sufficiently distinctive to permit identification of fragments. Some specimens have radial ribs that are relatively broad folds (fig. $4, g$ ) rather than sharp, narrow ribs. Some of these broader structures may be secondary features formed by deformation of the shell.

A remarkable specimen from Woody Island (USGS Mesozoic loc. M5963) shows that at a mature growth stage, peculiar fingerlike projections develop along the ventral margin. Four fingers are clearly shown on fig. 5 , but the total number cannot be observed because of the fragmentary nature of this specimen. The purpose of this unusual feature is unknown, but possibly the fingers supported mantle flaps or folds that aided in maintaining buoyancy. Another kind of inoceramid is 

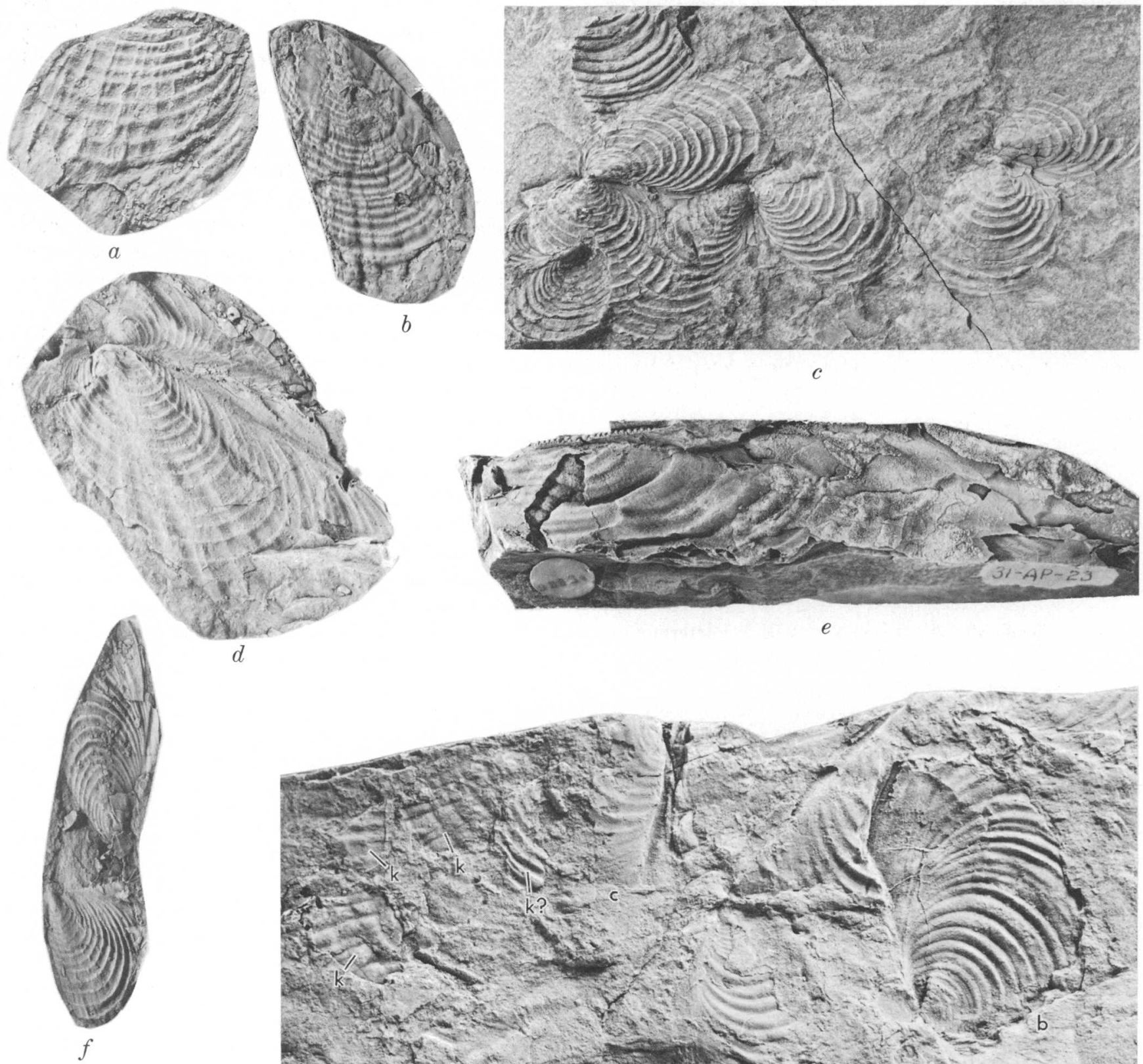

$c$
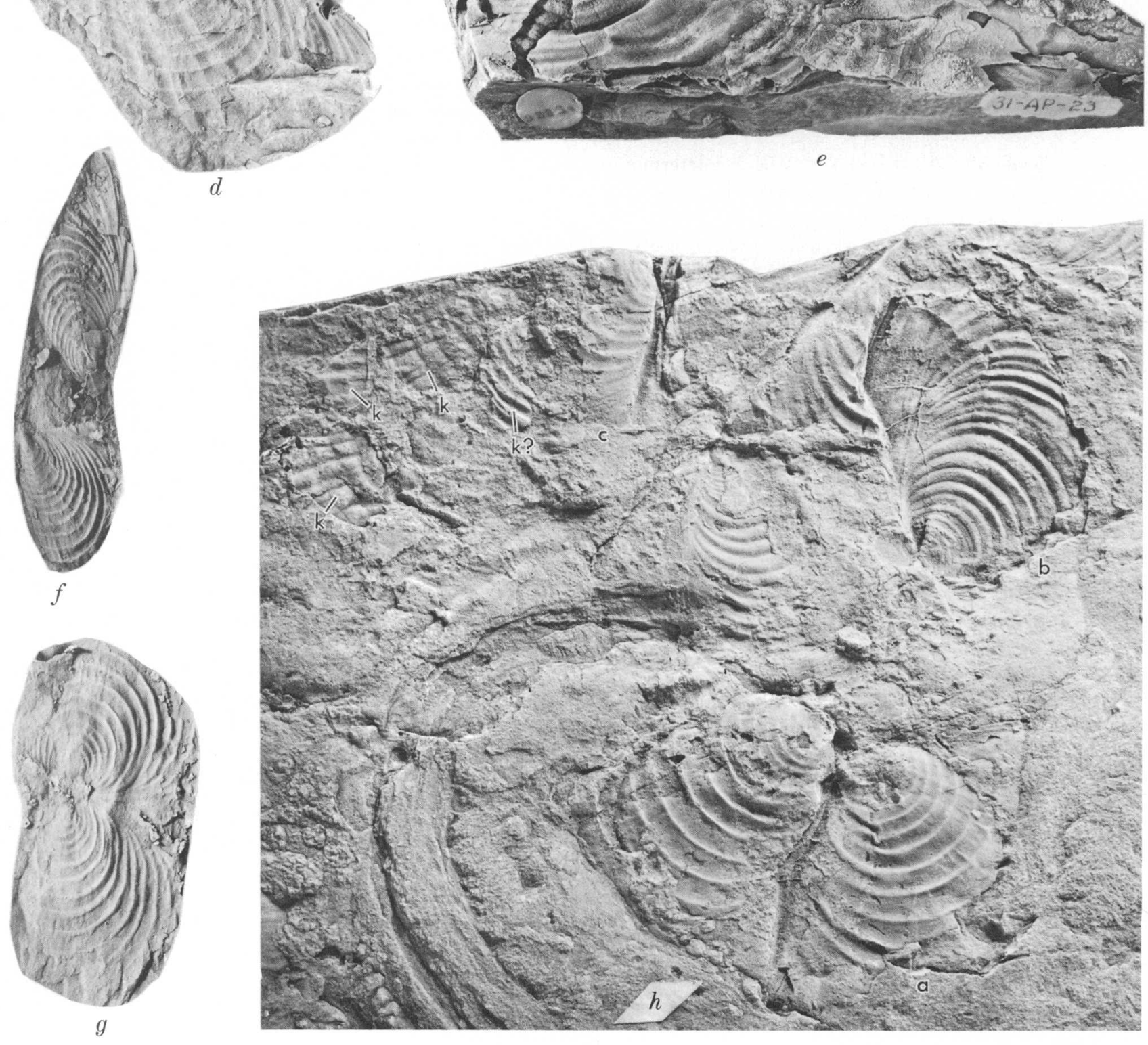

Figure 3. 
associated with I. kusiroensis in a few localities in the Chugach Mountains and on Woody Island. This is Inoceramya concentrica Ulrich $(1910$, p. 134), the syntypes of which are refigured on figure $3, h$. At least six fragmentary specimens are exposed on the type slab; Ulrich figured three of them (these are labeled on figure $3, h$ as a, b, c). Because a holotype was not specified by Ulrich, we designated as lectotype of Inoceramya concentrica the bivalved fragment labeled a.

This specimen shows well-developed concentric ribs that are separated by nearly flat, broad, interrib areas. Spacing between ribs increases with growth, attaining a maximum of about 4 $\mathrm{mm}$. Faint radial striae are visible between ribs on the preserved anterior parts of the valves. Concentric ribs become faint on the flattened posterodorsal part of the valves. Anterior and ventral margins and hinge plate are not preserved.

The other syntypes differ somewhat from the lectotype. Specimen b shows well-preserved concentric rings that are more closely spaced than on the lectotype and become more closely spaced with growth. Specimen $\mathrm{c}$ is a well-preserved umbonal fragment that shows the ligament pits. Several other fragments found near specimen c, that may or may not belong with this specimen, show the reticulate rib pattern of $I$. kusiroensis; these are labeled $\mathrm{k}$ on figure $3, h$. The umbonal part may also be of this species, but a positive determination is not possible. In any case, it is not clear that these syntypes belong to the same species as the lectotype.

The status of the genus Inoceramya is questionable, and its differentiation from Inoceramus sensu lato is in doubt.

Figure 3.-Photographs of Inoceramus kusiroensis Nagao and Matsumoto and of $I$. concentrica Ulrich. Natural size.

a-g. Inoceramus kusiroensis $\mathrm{Nagao}$ and Matsumoto.

a. Fragment of right valve, USNM 18344lb from USGS Mesozoic loc. M5369, showing reticulate pattern of ornamentation. This specimen is on the same large slab as that of figure $4, f$. Rubber cast.

b. Left valve, USNM 183645 from USGS Mesozoic loc. M571 (Matanuska Formation), showing well-developed radial ribs.

c. Slab, USNM 183646 from USGS Mesozoic loc. M570 (Matanuska Formation). Juvenile specimens that lack well-developed radial ribs.

d. Left valve and umbo of right valve, USNM 183647 from USGS Mesozoic loc. 7378. Rubber cast.

c. Crushed left valve, USNM 183648a from USGS Mesozoic loc. 1.5966, showing ligament pits on hinge.

$f$. Left and right valves, USNM 183648b from USGS Mesozoic loc. 15966. Note similarity to specimens from Matanuska Formation shown in this figure, $c$. Rubber cast.

g. Left and right valves, USNM 183649 from USGS Mesozoic loc. M5369. Note close similarity to Inoceramya concentrica, $h$ of this figure, which has more widely spaced concentric ribs. Rubber cast.

h. Inoceramya concentrica Ulrich.

Type slab, USNM 30210, from Woody Island. Syntypes figured by Ulrich are labeled a, b, and c. Specimen $a$ is herein designated as the lectotype of $I$. concentrica. Fragments of Inoceramus kusiroensis are indicated by $k$.
According to Ulrich (1910) and Cox $(1969$, p. N317) the main characters that separate Inoceramya from Inoceramus are: lack of prismatic shell, ligament pits that are small and numerous and decrease in size toward the ends of the hinge margin, presence of an internal riblike swelling that extends obliquely backward from the umbo, regular concentric ribs that are absent from the posterodorsal region, and nonprotruding umbones located near the middle of the hinge margin. Of these features, the lack of prismatic shell is due to nonpreservation, and only the regular concentric ornamentation can be accredited assuredly to Inoceramya concentrica. The other features are not displayed by the lectotype and may indeed be characteristics of another species.

The type locality of Inoceramya concentrica was not precisely located in the original report, although on the basis of a drawing of the islands in Kodiak harbor (Emerson, 1910, p. 52, fig. 12) and a brief description of the locality (p. 51), it is apparent that the fossils were obtained from the northwest shore of Woody Island. A detailed search of the entire island by the writers resulted in discovery of three Inoceramusbearing fossil localities, all on the northwest shore. This is the only place on the island where the metamorphic grade is relatively low and where the top surfaces of beds are well exposed. The position of our new localities is shown on figure 6. In addition to the Inoceramus shells, tubes of Terebellina palachei Ulrich and trace fossils are fairly common in these exposures, and most of the forms described by Ulrich can be found. The strike of the beds is approximately parallel to the shoreline, and only a small stratigraphic interval is exposed there. Hence, our localities must lie nearly at the same stratigraphic horizon as Ulrich's original specimens.

Unfortunately, no well-preserved specimens of Inoceramya concentrica were found that shed more light on the nature of this poorly known form. Several specimens were found with well-developed concentric ribs, but these could be either $I$. concentrica or Inoceramus kusiroensis. A large specimen of the latter from USGS Mesozoic loc. M5963 is illustrated in figure 5.

\section{AGE, CORRELATION, AND DEPOSITIONAL ENVIRONMENT}

Inoceramus kusiroensis occurs in Hokkaido, Japan, in association with $I$. shikotanensis Nagao and Matsumoto, a guide fossil to the Japanese upper Hetonaian (K6ß) substage (Matsumoto, 1.954, p. 37; 1959, pl. 8), which is correlated by Japanese paleontologists with the lower part of the Maestrichtian Stage of Europe. A comparable age seems warranted for the Chugach specimens.

Inoceramus kusiroensis is locally abundant in the Matanuska Formation in the lower Matanuska Valley (see identifications by Jones in Grantz, 1964, p. 124). The best fossils are from USGS Mesozoic localities 6692, M570, M571, M584, M585, and M589 (see Grantz, 1.964, p. 1.25 and fig. 2 for location of these collections) in the upper part of the Matanuska 

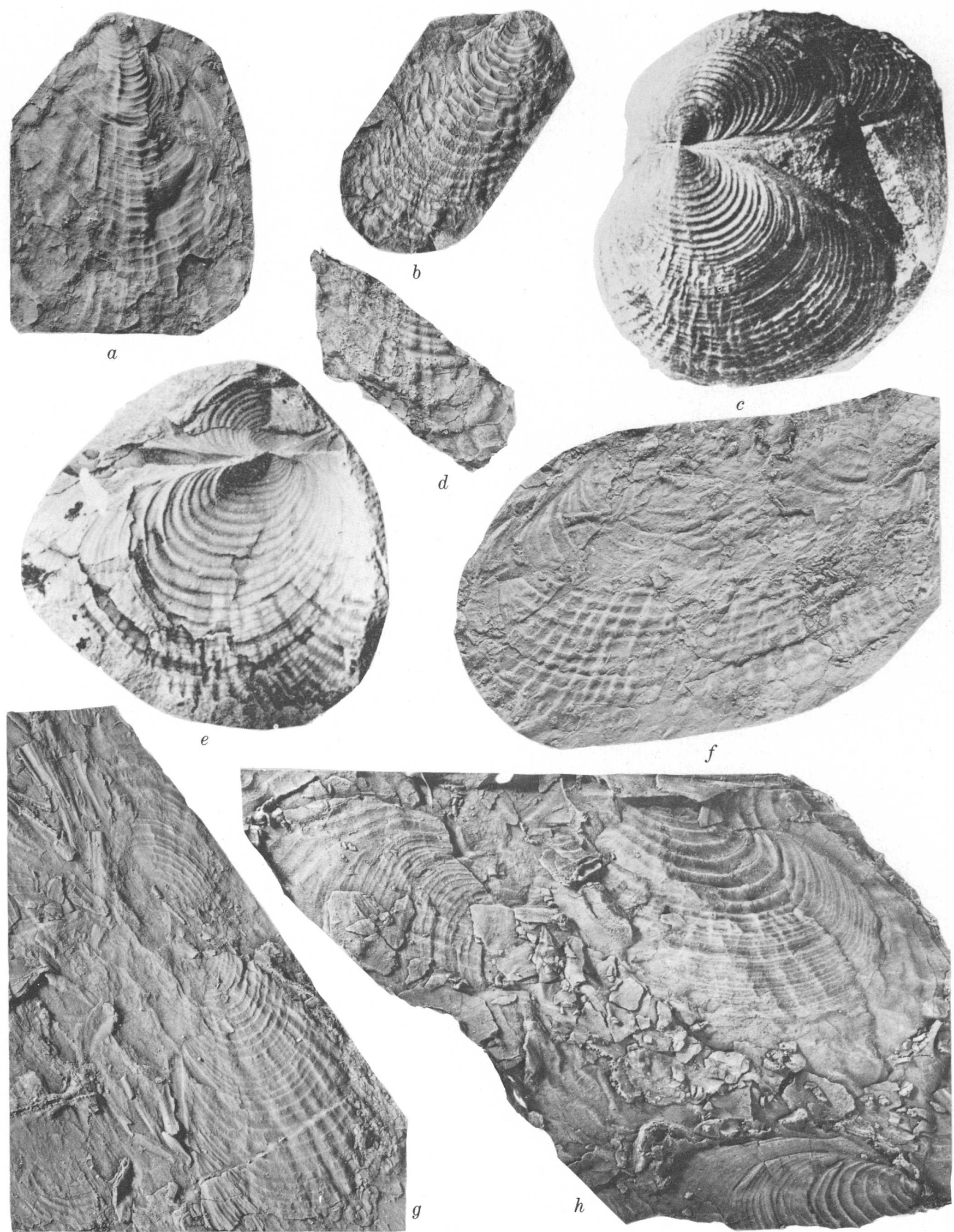

$f$

Figure 4. 
Formation, as determined by Grantz; some occur with ammonites of the Pachydiscus kamishakensis zone of late Campanian and Maestrichtian age.

The Matanuska Formation is relatively fossiliferous, and locally contains abundant specimens of ammonites and Inoceramus (Jones, 1963, 1967). It thus contrasts markedly with the poorly fossiliferous flysch deposits of the Chugach terrane, which have yielded no molluscan fossils except for the Inoceramus described in this report. The Matanuska Formation probably accumulated on a narrow, unstable continental shelf where depths of water were mainly in the neritic to upper bathyal zones (Grantz, 1964, p. 122; Jones and others, 1971; Berg and others, 1972). The rocks of the Chugach terrane lying to the south apparently formed in much deeper water, perhaps on a continental rise or in a trench at the margin of the continent (Payne, 1955; Moore, 1972; Berg and others, 1972). This postulated environment is supported not only by the lack of shallow-water fossils but also by the character of bedding and sedimentary structures, which are typical of deepwater deposits (Burk, 1965; Plafker and MacNeil, 1966; Moore, 1972; Clark, 1972a, b).

The presence of Inoceramus kusiroensis in both the shallowwater deposits of the Matanuska Formation and the deepwater deposits of the Chugach Mountains raises a question as to the environmental conditions under which this organism lived. It seems doubtful that this species, alone among the Late Cretaceous marine mollusks of southern Alaska, actually could inhabit such a wide ecological niche. It seems more likely that

Figure 4.--Photographs of Inoceramus kusiroensis Nagao and Matsumoto and of Inoceramus cf. I. kusiroensis. Natural size.

$a, c-h ;$ Inoceramus kusiroensis Nagao and Matsumoto.

a. Left valve, USNM 183639 from USGS Mesozoic loc. M5369. Concentric ribs are evenly spaced throughout in constrast to most specimens that have narrowly spaced ribs in midgrowth stages. Rubber cast.

c. Holotype, Hk. 7271a. Reproduced from Nagao and Matsumoto, 1940 , pl. 22 , fig. 4 .

d. Fragment of left(?) valve, USNM 183640 from USGS Mesozoic loc. M571 (Matanuska Formation), showing reticulate ornamentation. Rubber cast.

e. Left valve and part of right valve, from Koryak Range, northeastern U.S.S.R. Reproduced from Vereshchagin and others, 1965, pl. 63 , fig. 2 .

f. Fragment of large specimen, USNM 18364la from USGS Mesozoic loc. M5369, showing well-developed reticulate ornamentation. Rubber cast.

g. Right and left valves, USNM 183642 from USGS Mesozoic loc. M5846. Note very coarse radial ribs. Rubber cast.

h. Slab, USNM 183643 from USGS Mesozoic loc. M5846. Note very coarse concentric rings on the two specimens on the right-hand part of slab. Rubber cast.

b. Inoceramus cf. I. kusiroensis.

USNM 183644 from USGS Mesozoic loc. M5868, Shumagin Islands. Radial ribs are not as strongly developed on Shumagin Islands specimens as on most forms from the Chugach Mountains and Woody Island.

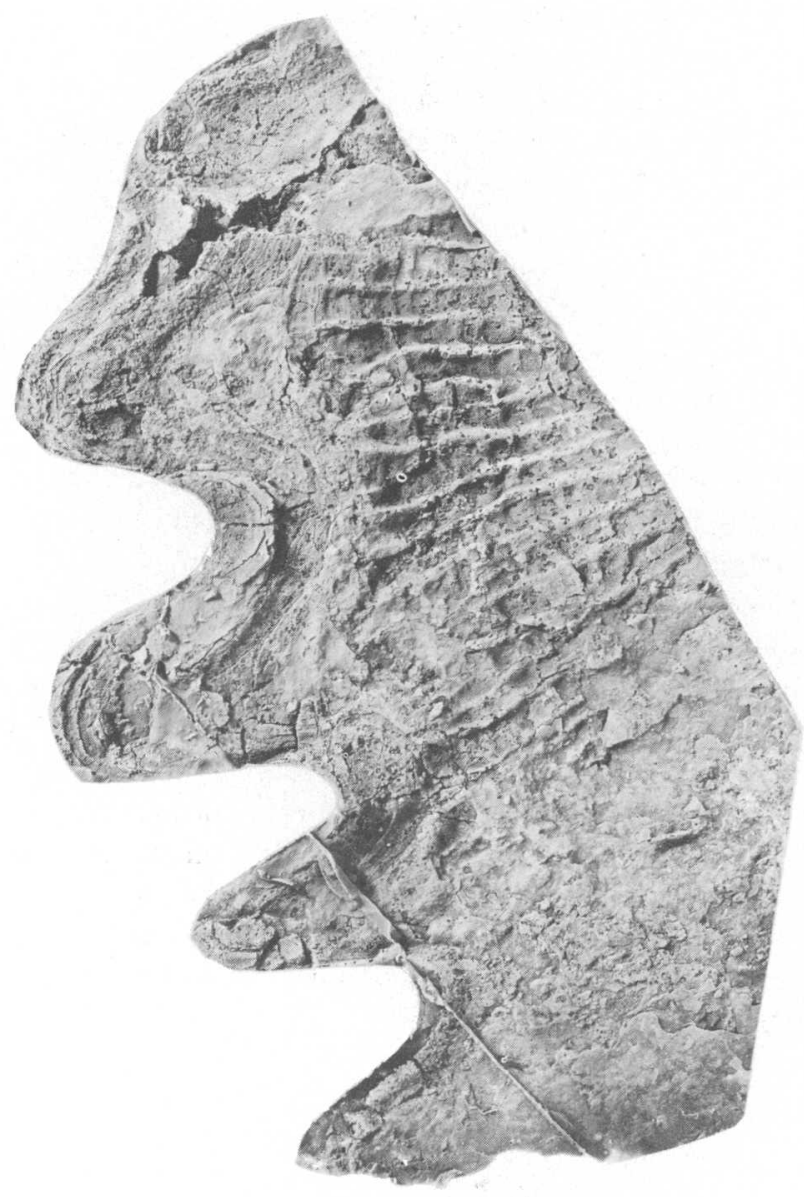

Figure 5.-Inoceramus kusiroensis, USNM 185747 from USGS Mesozoic loc. M5963, Woody Island. Note strong radial ribs and development of fingerlike projections on ventral margin.

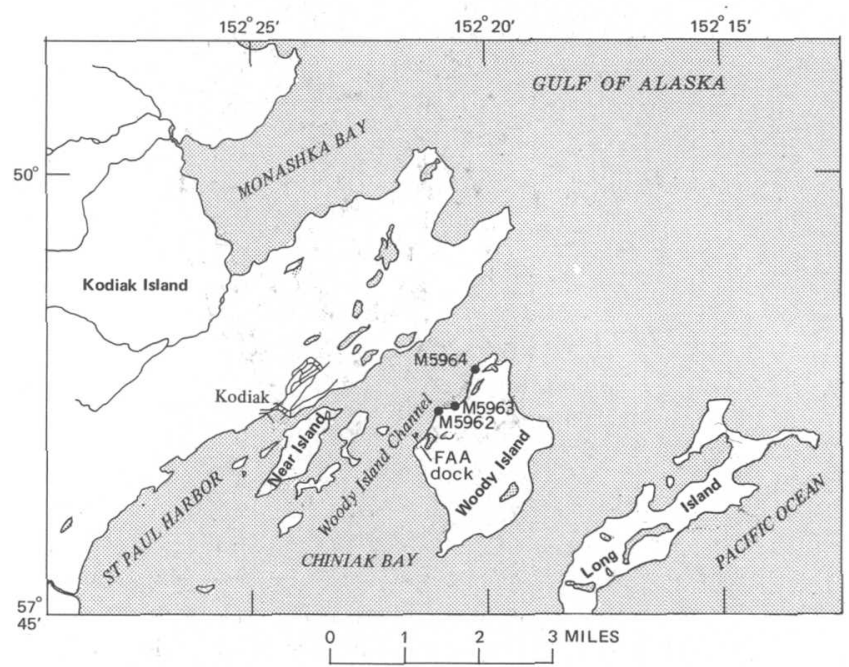

Figure 6.-Map showing fossil localities on Woody Island. 
the Inoceramus shells were transported from shallow water where they lived, to deep water, where they became entombed in the sediment. But if this is so, why were only the Inoceramus transported, and not shells of ammonites and other forms that are so common in the Matanuska Formation but totally unknown from the Chugach rocks? And what was the mode of transportation that carried these thin-shelled, fragile mollusks without breaking them into small fragments?

A possible explanation for the distribution of Inoceramus kusiroensis in both shallow-water and deepwater deposits is that it had a pseudoplanktonic habit (Hayami, 1969) and lived suspended in the near-surface waters, perhaps attached to drifting seaweed. Upon death the shells would settle to the bottom and accumulate on bedding planes. A number of specimens show both valves still together, but spread open and lying flat along the bedding plane (fig. 7; fig. 4, g). These specimens have not been carried far by bottom currents; otherwise the two valves, which lack hinge teeth, would have been separated.

If this interpretation of a pseudoplanktonic habit is correct, the presence of $I$. kusiroensis provides no direct information about the environment of deposition of the enclosing sediments. As this species does appear to be more abundant in the deeper water deposits than in the shelf deposits, it may have flourished well offshore.

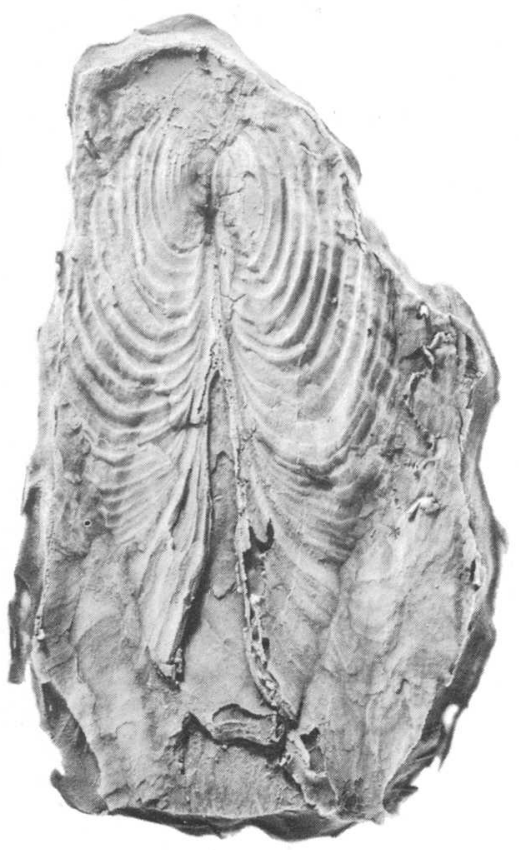

Figure 7.-Inoceramus kusiroensis, USNM 183650, from USGS Mesozoic locality 15965 (fig. 2). Rubber cast. Left and right valves of nearly complete specimen spread open along bedding plane in black argillite. The two valves, which lack hinge teeth, could not have been carried to the burial site by strong bottom currents without disarticulation.
Specimens of Inoceramus are locally abundant on the Shumagin Islands to the southwest, particularly on Nagai Island (fig. 8). Some of these closely resemble I. kusiroensis, except that radial ribs are not as strongly developed (see fig. 4 , $b$ ). The significance of this difference is not known; it may be

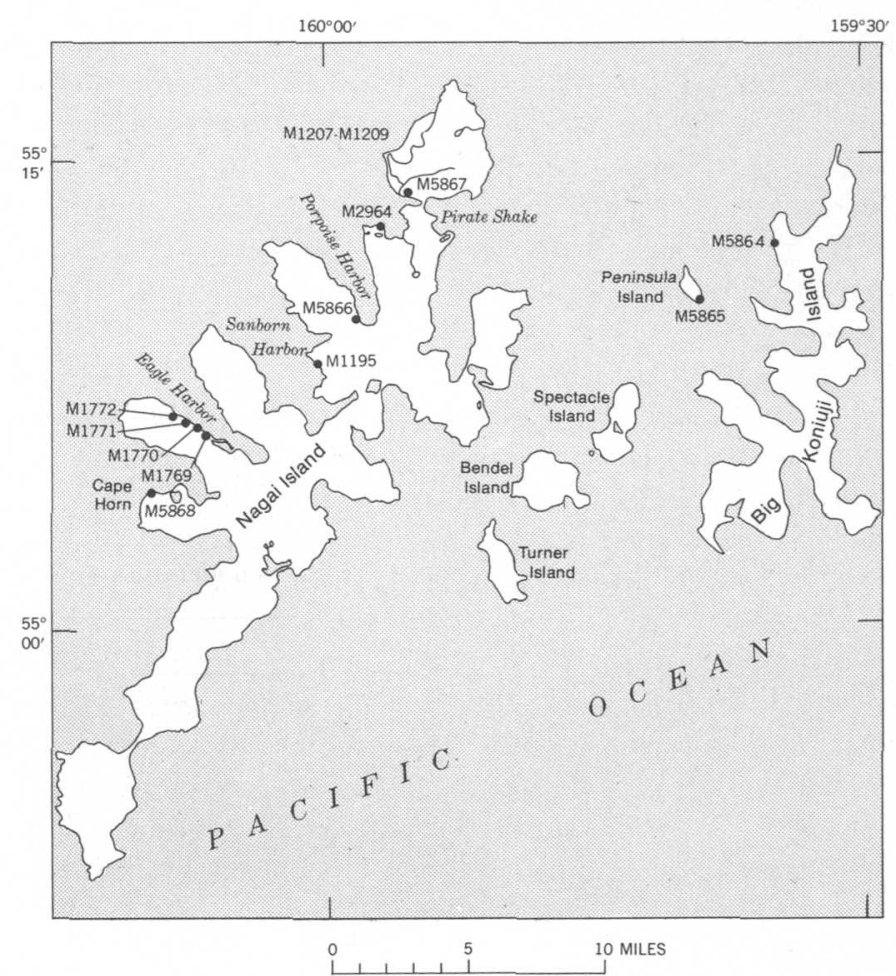

Figure 8.-Map of Shumagin Islands, showing fossil locations.

normal variation in a slightly younger or older subspecies, or it might be related to somewhat different ecological conditions. In any case, the Shumagin Islands rocks appear to be grossly similar in age to those of the Valdez Group and related rocks near Anchorage.

The Valdez Group and related rocks of the Chugach terrane in southern Alaska are similar in lithological character to rocks exposed in the Chugach Mountains east of the Copper River (Yakutat Group) as pointed out by Plafker and MacNeil (1966, p. B63-B64). They are also grossly similar to rocks in southeastern Alaska on Baranof and Chichagof Islands (Sitka Graywacke of Loney and others, 1963, 1964). As both the Yakutat Group and the Sitka Graywacke contain Buchia of earliest Cretaceous (Berriasian) age, they are in part much older than any of the Inoceramus kusiroensis-bearing rocks identified in southern Alaska. Some of the rocks of the Yakutat Group, however, are nearly contemporaneous with these Maestrichtian rocks, as Plafker and Perkins have found Inoceramus schmidti of Campanian age in Yakutat Bay (USGS Mesozoic loc. M5108). This fossil is well known from the 
Matanuska Formation (Jones, 1963), where it occurs in a faunal zone directly below that containing Inoceramus kusiroensis. Because of this close proximity in age, and judged by the great thickness of rocks involved in both the Yakutat and the Valdez Group and related rocks, it seems reasonable to suppose that they are, in part, coeval, even though an exact equivalency cannot be demonstrated on a faunal basis.

The absence of older fossils from the Chugach terrane of southern Alaska is surprising in view of the fairly large number and wide distribution of the known fossil localities. The same Maestrichtian fossils occur near the northwestern boundary of the belt (Turnagain Arm), near the southeastern boundary (Woody Island), and also near the center of the belt (Barry Arm). Such a wide distribution suggests that if older rocks are present at all, they may be very limited in extent.

Table 1.-Description of Upper Cretaceous fossil localities referred to in text

\begin{tabular}{ccc}
\hline U.S. Geol & Field & $\begin{array}{c}\text { Collector, year of collection, } \\
\text { description of locality, } \\
\text { Survey } \\
\text { Mesozoic }\end{array}$ \\
loc. No. & No. & and fossil identifications
\end{tabular}

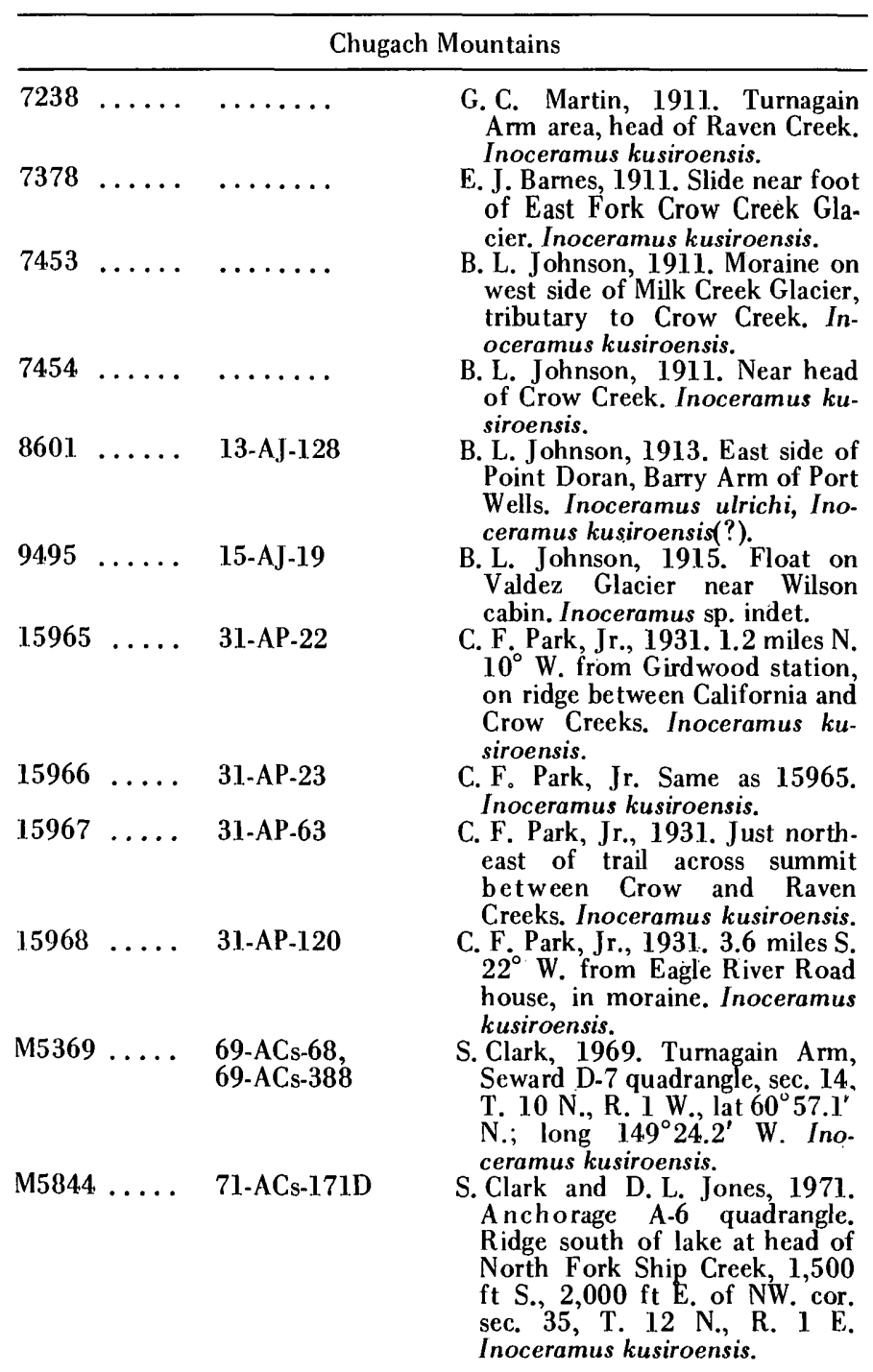

Table 1.-Description of Upper Cretaceous fossil localities referred to in text-Continued

\begin{tabular}{ccc}
\hline $\begin{array}{c}\text { U.S. Geol. } \\
\text { Survey } \\
\text { Mesozoic } \\
\text { loc. No. }\end{array}$ & $\begin{array}{c}\text { Field } \\
\text { No. }\end{array}$ & $\begin{array}{c}\text { Collector, year of collection, } \\
\text { description of locality, } \\
\text { and fossil identifications }\end{array}$ \\
\hline
\end{tabular}

\begin{tabular}{|c|c|c|}
\hline M5845 . . . & 71-ACs- 175 & $\begin{array}{l}\text { S. Clark and D. L. Jones, } 1971 . \\
\text { Anch orage A-6 quadrangle. } \\
\text { Ridge south of lake at head of } \\
\text { North Fork Ship Creek, 2,000 } \\
\text { ft S., } 250 \mathrm{ft} \text { E. of NW. cor. sec. } \\
35 \text {, T. } 12 \text { N., R. I E. Inocera- } \\
\text { mus cf. I. kusiroensis. }\end{array}$ \\
\hline M5846 .... & 71-ACs-328 & $\begin{array}{l}\text { S. Clark and G. R. Winkler, } 1971 . \\
\text { North shore of Turnagain Arm, } \\
\text { Anchorage Highway, } 2,000 \mathrm{ft} \\
\text { S., } 400 \mathrm{ft} \text { W. of NE. cor. sec. } \\
15, \text { T. } 10 \text { N., R. } 1 \mathrm{~W} \text {. Inocera- } \\
\text { mus kusiroensis. }\end{array}$ \\
\hline M5848 . . & 71-ACs-2033 & $\begin{array}{l}\text { S. Clark, M. E. Yount, and P.S. } \\
\text { Morse, } 1971 . \text { Seward D-7 quad- } \\
\text { rangle. South shore of Turn- } \\
\text { again Arm, Hope Highway east } \\
\text { of Sunset Creek, 1,500 ft N., } \\
2,800 \mathrm{ft} \text { E. of SW. cor. sec. 33, } \\
\text { T. } 10 \mathrm{~N} \text {., R. } 1 \text { W. Inoceramus } \\
\text { kusiroensis. }\end{array}$ \\
\hline
\end{tabular}

Kodiak and Shumagin Islands

$\begin{array}{lll}\text { USNM } 30210 & \ldots \ldots & \text { W. H. Dall, 1895. Woody Island }\end{array}$ near Kodiak, on shore facing Chiniak Bay. "Inoceramya concentrica" (= Inoceramus ulrichi Jones and Clark) and Inocera-

M1195 .... 134-A1-3

mus kusiroensis

C. A. Burk, 1961.' Shumagin Islands, Sanborn Harbor, lat $55^{\circ} 8.5^{\prime} \mathrm{N}$.; long $160^{\circ} 0.5^{\prime} \mathrm{W}$. Inoceramus cf. I. kusiroensis.

M1207 ... 135-A4-5 $\quad$ C. A. Burk, 1958-61. West of

M1209 .... 135-A4-15 Pirate Shake, Nagai Island. Inoceramus cf. I. kusiroensis.

M1770 .... 62-AGz-9

ceramus cf. T. kusiroensis.
Arthur Grantz, 1962. Shumagin Islands, Nagai Island, Eagle Harbor lat $55^{\circ} 6.4^{\prime} \quad \mathrm{N}$.; long $160^{3} 7.3^{\prime}$ W. Inoceramus ef. $I$. kusiroensis.

M1771 ... 62-AGz-10

kusiroensis.

Arthur Grantz, 1962. Shumagin Islands, Nagai Island, Eagle Harbor lat $55^{\circ} 6.6^{\prime}$ N.; long $160^{8} 7.7^{\prime} \mathrm{W}$. Inoceramus of. $I$. kusiroensis.

$\mathrm{M} 1772 \ldots .6 \quad 62-\mathrm{AGz}-11$

Arthur Grantz, 1962. Shumagin Islands, Nagai Island, Eagle Harbor lat $55^{\circ} 6.6^{\prime}$ N.; long $160^{6} 7.9^{\prime} \mathrm{W}$. Inoceramus ef. I. kusiroensis.

M2964 .... 16098-19

Standard Oil Company of Calif. ornia, year unknown. Nagai Island, lat $55^{\circ} 12.8^{\prime} \mathrm{N}$.; long $159^{\circ} 56.7^{\prime}$ W., Northeast shore of eastern point at Porpoise Harbor. Inoceramus :cf. I. ku-

siroensis.
J. C. Moore, 1969-1970. Big

M5864 .... N-140F Koniuji Island, northeastern peninsula, 2.1 miles N. $38^{\circ} 30^{\prime}$ W. of triangulation station Koniuji. Inoceramus cf. $1 . \mathrm{ku}$ siroensis and Inoceramus sp.

M5867 .... N-115E
J. C. Moore, 1969-1970. Nagai Island, south side of stream east of Porpoise Rocks, 2.5 miles N. $50^{\circ} 30 \mathrm{~W}$. of triangulation station Wreck. Inoceramus of. $I$. kusiroensis. 
Table 1.-Description of Upper Cretaceous fossil localities referred to in text-Continued

\begin{tabular}{|c|c|c|}
\hline $\begin{array}{l}\text { U.S. Geol. } \\
\text { Survey } \\
\text { Mesozoic } \\
\text { loc. No. }\end{array}$ & $\begin{array}{c}\text { Field } \\
\text { No. }\end{array}$ & $\begin{array}{l}\text { Collector, year of collection, } \\
\text { description of locality, } \\
\text { and fossil identifications }\end{array}$ \\
\hline \multicolumn{3}{|c|}{ Kodiak and Shumagin Islands-Continued } \\
\hline M5868 & $\mathrm{N}-8 \mathrm{~A}$ & $\begin{array}{l}\text { J. C. Moore, 1969-1970. Nagai } \\
\text { Island, Cape Horn. Inoceramus } \\
\text { cf I. kusiroensis. }\end{array}$ \\
\hline M5962 & 72 Acs 489 & 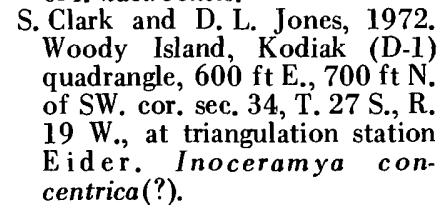 \\
\hline 'M5963 ..... & $72 A$ cs 490 & $\begin{array}{l}\text { S. Clark and D. L. Jones, } 1972 . \\
\text { Woody Island, Kodiak (D-1) } \\
\text { quadrangle, } 1,700 \mathrm{ft} \mathrm{E} ., 1,000 \mathrm{ft} \\
\mathrm{N} . \text { of SW. cor sec. } 34, \mathrm{~T} .27 \mathrm{~S} \text {, } \\
\mathrm{R} .19 \mathrm{~W} \text {. Inoceramya con- } \\
\text { centrica(?), Inoceramus kusiro- } \\
\text { ensis. }\end{array}$ \\
\hline M5964 ..... & $72 \operatorname{Acs} 492$ & $\begin{array}{l}\text { S. Clark and D. L. Jones, Woody } \\
\text { Island, Kodiak (D-1) quad- } \\
\text { rangle, } 3,200 \mathrm{ft} E ., 3,650 \mathrm{ft} \mathrm{N} \text {. } \\
\text { of SW. cor. sec. } 34, \mathrm{~T} .27 \mathrm{~S} ., \mathrm{R} . \\
19 \text { W.I. kusiroensis(?). }\end{array}$ \\
\hline
\end{tabular}

\begin{tabular}{|c|c|c|}
\hline \multicolumn{3}{|c|}{ Location of Inoceramus schmidti from Yakutat Group } \\
\hline M5108 ..... & 68-APs-72E & $\begin{array}{l}\text { G. Plafker and M. Perkins, } 1968 \\
\text { and } 1969 \text {. Yakutat } 1: 250,000 \\
\text { quadrangle, SE1/4 sec. 23, T. } 25 \\
\text { S., R. 35 E., above Rasmussen } \\
\text { Glacier. Yakutat Group. }\end{array}$ \\
\hline
\end{tabular}

Location of figured specimens from Matanuska Valley

\begin{tabular}{|c|c|c|}
\hline M570 ..... & 59-AGz-M35 & $\begin{array}{l}\text { D. L. Jones and Arthur Grantz, } \\
1959 \text { Carbon Creek, lat } \\
61^{\circ} 46^{\prime} 20^{\prime \prime} \mathrm{N} \text {.; long } 148^{\circ} 27^{\prime} 35^{\prime \prime} \\
\text { W. Matanuska Formation, Ino- } \\
\text { ceramus kusiroensis. }\end{array}$ \\
\hline M571. & 59-AGz-M36A & $\begin{array}{l}\text { D. L. Jones and Arthur Grantz, } \\
1959 \text { Carbon Creek, lat on } \\
61^{\circ} 46^{\prime}, 15^{\prime \prime} \mathrm{N} \text {.; long } 148^{\circ} 27^{\prime} 30^{\prime \prime} \\
\text { W. Matanuska Formation, Ino- } \\
\text { ceramus kusiroensis. }\end{array}$ \\
\hline
\end{tabular}

\section{REFERENCES CITED}

Berg, H. C., Jones, D. L., and Richter, D. H., 1972, Gravina-Nutzotin belt-Tectonic significance of an upper Mesozoic sedimentary and volcanic sequence in southern and southeastern Alaska, in Geological Survey Research 1972: U.S. Geol. Survey Prof. Paper 800-D, p. D1-D24.

Burk, C. A., 1965, Geology of the Alaska Peninsula-Island arc and continental margin: Geol. Soc. America Mem. 99, pt. 1, 250 p.

Clark, S. H. B., 1972a, Reconnaissance bedrock geologic map of the Chugach Mountains near Anchorage, Alaska: U.S. Geol. Survey Misc. Inv. Field Studies Map MF-350. [In press]

_ 1972b, The McHugh Complex of south-central Alaska: U.S. Geol. Survey Bull. .1372-D.

Cox, L. R., 1969, Family Inoceramidae, in Moore, R. C., ed., Treatise on Invertebrate Paleontology, pt. N. v. 1, Mollusca 6: Boulder, Colo., and Lawrence, Kans., Geol. Soc. America (and Kansas Univ. Press), p. N314-N321.

Emerson, B. K., 1910, Notes on the stratigraphy and igneous rocks, in Harriman Alaska series, v. 4, Geology and Paleontology, p. 11-56.
Grantz, Arthur, 1964, Stratigraphic reconnaissance of the Matanuska Formation in the Matanuska Valley, Alaska: U.S. Geol. Survey Bull. 1181-I, p. I1-I33.

Hayami, Itaru, 1969, Notes on Mesozoic "planktonic" bivalves: Jour. Geology [Japan], v. 75, no. 7, p. 375-385 [English abs. p. 385].

Imlay, R. W., and Reeside, J. B., Jr., 1954, Correlation of the Cretaceous Formations of Greenland and Alaska: Geol. Soc. America Bull., v. 65, p. 223-246.

Jones, D. L., 1963, Upper Cretaceous (Campanian and Maestrichtian) ammonites from southern Alaska: U.S. Geol. Survey Prof. Paper 432,53 p. [1964]

- 1967, Cretaceous ammonites from the lower part of the Matanuska Formation, southern Alaska: U.S. Geol. Survey Prof. Paper $547,49 \mathrm{p}$.

Jones, D. L., MacKevett, E. M., Jr., and Plafker, George, 1971, Speculations on late Mesozoic tectonic history of part of southern Alaska: Am. Assoc. Petroleum Geologists, Second Internat. Symposium on Arctic Geology, Program Abs., p. 30.

King, P. B., compiler, 1969, Tectonic map of North America: U.S. Geol. Survey, scale 1:5,000,000.

Loney, R. A., Berg, H. C., Pomeroy, J.S., and Brew, D. A., 1963, Reconnaissance geologic map of Chichagof Island and northwestern Baranof Island, Alaska: U.S. Geol. Survey Misc. Geol. Inv. Map I-388, scale 1:250,000,

Loney, R. A., Pomeroy, J. S., Brew, D. A., and Muffler, L. J. P., 1964, Reconnaissance geologic map of Baranof and Kruzof Islands, Alaska: U.S. Geol. Survey Misc. Geol. Inv. Map I-411, scale $1: 250,000$.

Martin, G. C., 1926, The Mesozoic stratigraphy of Alaska: U.S. Geol. Survey Bull. 776, $493 \mathrm{p}$.

Matsumoto, Tatsuro, 1954, The Cretaceous system in the Japanese Islands: Tokyo, Japan, Japanese Soc. Promotion Sci. Research, $324 \cdot \mathrm{p}$.

1959, Zonation of Upper Cretaceous in Japan: Kyushu Univ. Fac. Sci. Mem., ser. D, Geology, v. 9, no. 2, p.55-93.

Moffit, F. H., 1954, Geology of the Prince William Sound region, Alaska: U.S. Geol. Survey Bull. 989-E, p. 225-310.

Moorc, C. W., 1969, New formations on Kodiak and adjacent islands, Alaska, in Changes in stratigraphic nomenclature by the U.S. Geological Survey, 1967: U.S. Geol. Survey Bull. 1274-A p. A27-A35.

Moore, J. C., 1972, 'Uplifted trench sediments-southwest Alaska-Bering Shelf edge: Science, v. 175, no. 4026, p. 1103-11.05.

Nagao, Tukumi, and Matsumoto, Tatsuro, 1940, A monograph of the Cretaceous Inoceramus of Japan, pt. 2: Hokkaido Univ., Fac. Sci., Jour., ser. 4, v. 6 , no. 1 , p. $1-64$.

Park, C. F., Jr., 1.933, The Gird wood district, Alaska: U.S. Geol. Survey Bull. 849-G, p. $381-424$.

Payne, T. G., (compiler), 1955, Mesozoic and Cenozoic tectonic elements of Alaska: U.S. Geol. Survey Misc. Geol. Inv. Map 1.84, scale $1: 5,000,000$.

Plafker, George, and MacNeil, F. S., 1966, Stratigraphic significance of Terrtiary fossils from the Orea Group in the Prince William Sound region, Alaska, in Geological Survey Research 1966: U.S. Geol. Survey Prof. Paper,550-B, p. B62-B68.

Schrader, F. C., 1900, A reconnaissance of a part of Prince William Sound and the Copper River district, Alaska, in 1898: U.S. Geol. Survey 20th Ann. Rept.; pt. 7, p. 408-410, 413.

Ulich, E. O., 1910, Fossils and age of the Yakutat Formation, in Harriman Alaska Series, v. 4, Geology and Paleontology, p. $125-146$.

Vereshchagin, V. N., Kinasov, V. P., Paraketsov, K. V., and Terekhova, G. P., 1965, Polevoi Átlas, Melovoi fauni Severo-Vostoka S.S.S.R.: Magadan, Gosudarst. Proizvodst. Geol. Dom. RSFSR, ServeroVostoch. Geol. Upravlenie, 66 p. [In Russian] 


\title{
LITHOSTROTION REISERI N. SP., A CERIOID COLONIAL CORAL FROM MERAMEC-AGE BEDS, LISBURNE GROUP, ARCTIC ALASKA
}

\author{
By AUGUStUS K. ARMStRONG, Menlo Park, Calif.
}

\begin{abstract}
Lithostrotion reiseri n. sp. is a cerioid, colonial coral, index fossil for microfossil zones 12-13 (Meramec) in the Lisburne Group in the central and eastern Brooks Range, arctic Alaska.
\end{abstract}

The studies of the Carboniferous biostratigraphy and the rugose colonial corals of arctic Alaska (fig. 1) (Armstrong, 1.970b, 1972a, 1972b; Armstrong and others, 1971; Mamet and Armstrong, 1972) have resulted in the description and delineation of the stratigraphic ranges of a number of species of cerioid lithostrotionoids (fig. 2). The genera are Lithostrotionella, Thysanophyllum, and Sciophyllum, each of which is characterized by major and minor septa that are discontinuous in the dissepimentarium. The genus Lithostrotion Fleming, whose major and minor septa are continuous through the dissepimentarium, is represented by five species of fasiculate Lithostrotion, subgenus Siphonodendron, and only one known species of cerioid Lithostrotion Fleming. Lithostrotion reiseri n. sp. is of interest not only because it is cerioid, but also because it can be readily recognized in the field by its continuous major and minor septa. In the area of its known occurrence in the central and eastern Brooks Range, it is an index fossil to zones 12-13 (Meramec) of the Lisburne Group (fig. 3).

The stratigraphic distribution of Lithostrotion reiseri $n$. sp. together with other known species of colonial rugose corals and B. L. Mamet's microfossil zonation in the Lisburne Group are shown in figure 2 .

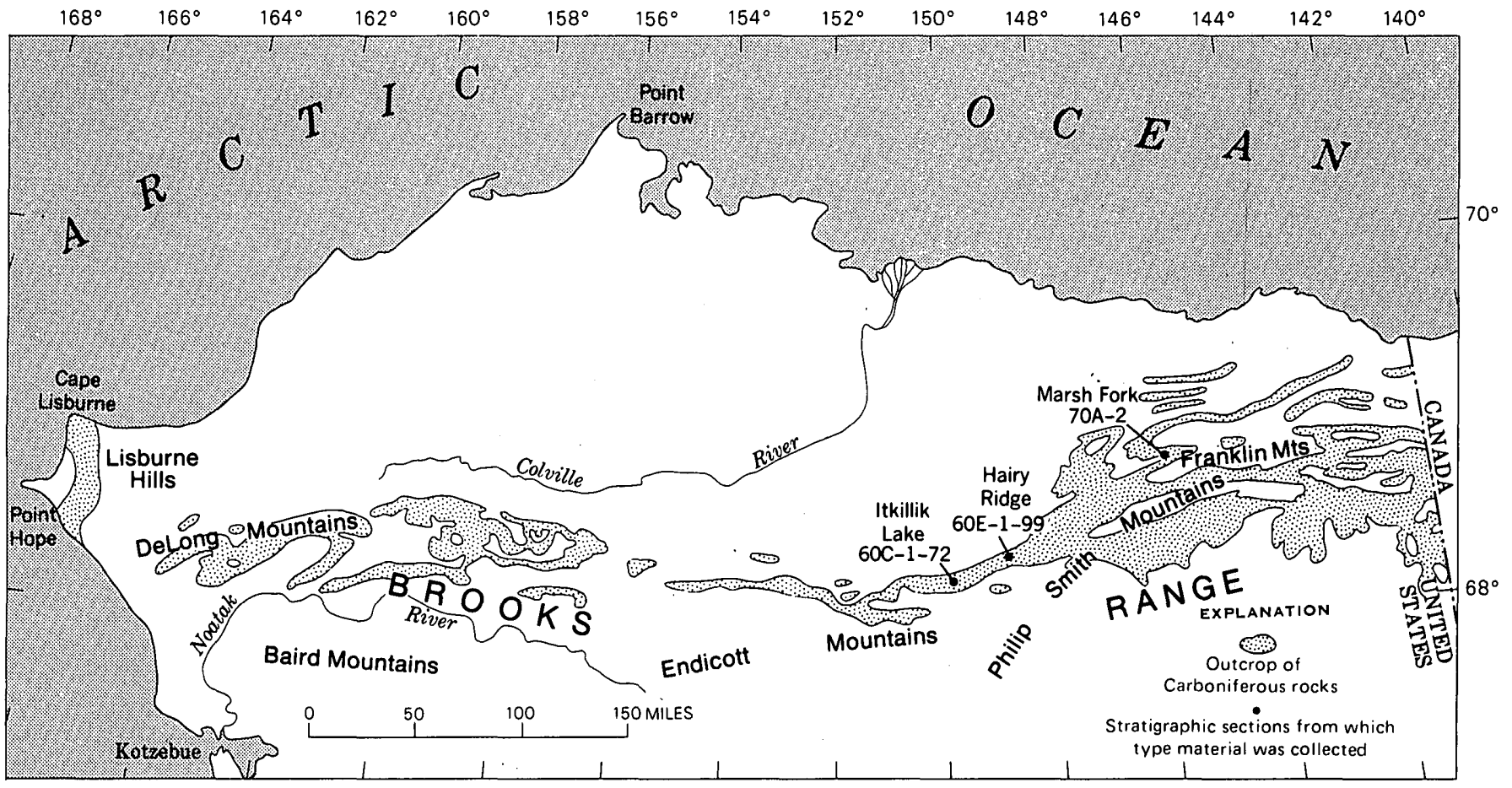

Figure 1.-Map of arctic Alaska, showing generalized locations of Carboniferous rock outcrops and of the type material for Lithostrotion reiseri $\mathrm{n}$. sp. 


\begin{tabular}{|c|c|c|c|c|c|c|c|c|c|c|c|c|c|c|c|c|}
\hline \multicolumn{14}{|c|}{ M I S S I S S I P P I A N } & \multicolumn{2}{|c|}{\begin{tabular}{|l} 
PENNSYL- \\
VANIAN \\
\end{tabular}} & System \\
\hline \multirow{2}{*}{\multicolumn{3}{|c|}{$\begin{array}{l}\text { Lower } \\
\text { Osage } \\
\end{array}$}} & \multicolumn{11}{|c|}{ Upper } & \multirow{4}{*}{\begin{tabular}{|c|} 
Lower \\
Morrow \\
20 \\
\end{tabular}} & \multirow{4}{*}{\begin{tabular}{|c|c|} 
Middle & \\
Atoka & \\
& \\
21 &
\end{tabular}} & Series \\
\hline & & & \multicolumn{6}{|c|}{ Meramec } & \multicolumn{5}{|c|}{ Chester } & & & Provincial Series \\
\hline \multicolumn{3}{|c|}{$\begin{array}{cc}\text { Burling- } \\
\text { ton } \\
\text { Limestone }\end{array} \quad \begin{array}{c}\text { Keokuk } \\
\text { Limestone }\end{array}$} & \multicolumn{3}{|c|}{$\begin{array}{c}\text { Salem } \\
\text { Limestone }\end{array}$} & \multicolumn{3}{|c|}{$\begin{array}{cc}\text { Ste } \\
\text { Lt. Louis } & \begin{array}{c}\text { Genevieve } \\
\text { Limestone } \\
\text { Limestone } \\
\text { Type section }\end{array}\end{array}$} & \multicolumn{4}{|c|}{ 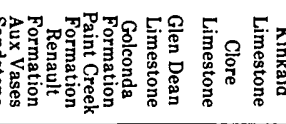 } & \multirow{2}{*}{ E्] } & & & Midcontinent formations \\
\hline 7 & 8 & 9 & 10 & 11 & 12 & 13 & 14 & 15 & $16_{\mathrm{i}}$ & $16_{\mathrm{s}}$ & 17 & 18 & & & & Mamet's microfossil zones \\
\hline & \multirow{21}{*}{ : } & & & & & & & & & & & & & & & Diphyphyllum venosum Armstrong \\
\hline & & & & & & & & & & & & & & & & Lithostrotion reiseri Armstrong \\
\hline & & & & & & & & & & & & & & & & Lithostrotion (S.) dutroi Armstrong \\
\hline & & & & & & & & & & & & & & & & Lithostrotionella pennsylvanica (Shimer) \\
\hline & & & & & & & & & & & & & & & & Lithostrotionella niakensis Armstrong \\
\hline & & & & & & & & & & & & & & & & Lithostrotionella banffensis (Warren) S.L. \\
\hline & & & & & & & & & & & & & & & & Diphyphyllum klawockensis Armstrong \\
\hline & & & & & & & & & & & & & & & & Lithostrotion (S.) sinuosum (Kelly) \\
\hline & & & & & & & & & & & & & & & & Lithostrotion (S.) warreni Nelson \\
\hline & & & & & & & & & & & & & & & & Sciophyllum alaskensis Armstrong \\
\hline & & & & & & & & & & & & & & & & Lithostrotionella mclareni (Sutherland) \\
\hline & & & & & & & & & & & & & & & & Thysanophyllum astraeiforme (Warren) \\
\hline & & & & & & & & & & & & & & & & Thysanophyllum orientale Thomson \\
\hline & & & & & & & & & & & & & & & & Sciophyllum lambarti Harker and Mclaren \\
\hline & & & & & & & & & & & & & & & & Lithostrotionella birdi Armstrong \\
\hline & & & & & & & & & & & & & & & & Lithostrotion (S.) lisburnensis Armstrong \\
\hline & & & & & & & & & & & & & & & & Diphyphyllum nasorakensis Armstrong \\
\hline & & & & & & & & & & & & & & & & Lithostrotionella aff $L$. mclareni (Sutherland) \\
\hline & & & & & & & & & & & & & & & & Lithostrotion (S.) ignekensis Armstrong \\
\hline & & & & & & & & & & & & & & & & Lithostrotionella wahooensis Armstrong \\
\hline & & & & & & & & & & & & & & & & Corwenia jagoensis Armstrong \\
\hline
\end{tabular}

Figure 2.-Stratigraphic distribution of Lithostrotion reiserin. sp. and other species of lithostrotionoids in The Lisburne Group. Zones are based on B. L. Mamet's microfossil-assemblage zones.

Kelly (1942) recognized that all the cerioid corals studied to that date which were considered to be Lithostrotion Fleming from the western United States and Canada, had discontinuous major septa in the dissepimentarium and were, in fact, Lithostrotionella Yabe and Hayasaka. Subsequent studies by Armstrong (1962, 1970a, 1970b, 1972a, 1972b), Sutherland (1958), Nelson (1960), Bamber (1966), Macqueen and Bamber (1967, 1968), Sando, Mamet, and Dutro (1969), Stensaas and Langenheim (1.960), Langenheim and Tischler (1.960), Sando (1960, 1963, 1969), Easton, Sanders, Knight, and Miller (1958), Bowsher (1961), Easton and Gutschick (1953), and Parks (1951) have failed to reveal cerioid corals from the North American Mississippian that can be placed without equivocation in the genus Lithostrotion. Lambe (1901) described a form, Lithostrotion macouni, which has small corallites about 2 to $3 \mathrm{~mm}$ in diameter, in which the majority of septa are continuous. Sutherland (1958, p. 94) believed the species to be a true Lithostrotion, but Nelson (1960, p. 122) stated, "The species is questionably referred to Lithostrotion because of the sublonsdaleoid dissepimentarium which some- times develops." Armstrong (1970b) reexamined the syntype and considered the species to be Lithostrotionella.

Lithostrotion-type corallites are common in many species of corals that have cerioid coralla, but they are found in association with corallites in the same corallum that have differing generic morphology. An individual corallite may even display at different levels in the corallum the traits of the genera Lithostrotionella Yabe and Hayasaka and Thysanophyllum Thomson. Species of the Lisburne Group that have generic polymorphism in the corallites of the coralla are Lithostrotionella mclareni (Sutherland), Lithostrotionella birdi Armstrong, Lithostrotionella niakensis Armstrong, and Sciophyllum lambarti Harker and McLaren. Within the first three of these species, generally, the majority of the corallites have the characteristics of the genus Lithostrotion. These three species also display some corallites that have continuous major and minor septa through the dissepimentarium. Other corallites have the morphology of Thysanophyllum.

Lithostrotion reiseri $\mathrm{n}$. sp., in contrast to all other known species of cerioid Mississippian corals in western North Amer- 


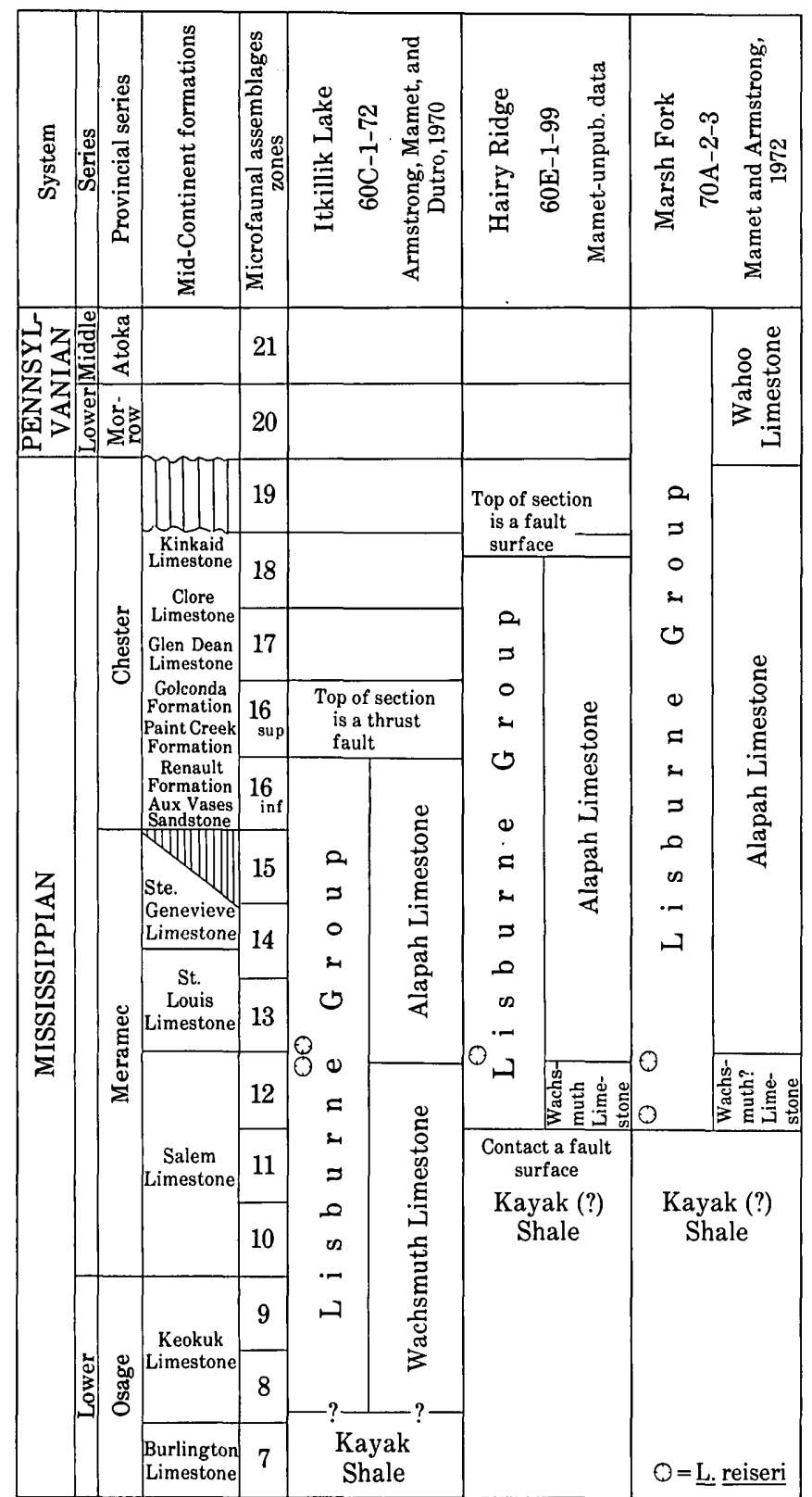

Figure 3.-Correlation chart for sections $60 \mathrm{C}-1-72$, Itkillik Lake; 60E-1-99, Hairy Ridge; and 70 A-2, Marsh Fork. ica, has corallites with continuous septa in the dissepimentarium in all the corallites of the corallum. The corallites average about $7 \mathrm{~mm}$ in diameter and are relatively uniform in their internal structures. The corallite diameters and the number of major septa in Lithostrotion reiseri n. sp. are shown on figure 4 .

Acknowledgments.-I wish to express my appreciation to Hillard Reiser, the party chief during the summers of 1969 , 1970, and 1971, for his generosity in supporting my coral collecting and stratigraphic studies of the Lisburne Group. I wish to thank the Naval Arctic Research Laboratory (Barrow), Office of Naval Research, for their logistical support of field work in the summers of 1969-1971. Large collections of corals, Foraminifera, and thin sections used in this study were collected by Shell Oil Co. geologists in 1959-1964. The collections I made in 1964 while employed by the company were given to the U.S. Geological Survey. Appreciation is extended to R. C. McAdams and G. E. Burton, vice presidents of Shell Oil Co. Dr. Bernard L. Mamet, of the Université de Montreal, kindly examined all the petrographic thin sections and made the microfossil and zone determinations used in this study. The photographs were made by Kenji Sakamoto, and the thin sections were made by Robert Shely and R. W. Hershiser, all of the U.S. Geological Survey.

\section{SYSTEMATIC PALEONTOLOGY}

\section{Phylum COELENTERATA}

\section{Class ANTHOZOA}

Order RUGOSA Milne-Edwards and Haime, 1850

Family LITHOSTROTIONIDAE d'Orbigny, 1851

\section{Genus LITHOSTROTION Fleming, 1828}

\section{Lithostrotion reiseri $\mathbf{n}$. sp.}

Figures 5-7

Material.-The material and specimens available for study are shown in Table 1.

Description.-The holotype USNM 161095 (fig. $5 a, b, d, e$; $6 b, c)$ is a cerioid corallum. In transverse section, corallites are

Table 1.-Description of materials and specimens available for study

\begin{tabular}{|c|c|c|c|c|c|c|}
\hline \multirow{2}{*}{$\begin{array}{l}\text { Strati- } \\
\text { graphic } \\
\text { section } \\
\text { No. }\end{array}$} & \multirow{2}{*}{$\begin{array}{l}\text { USNM } \\
\text { No. }\end{array}$} & \multirow{2}{*}{$\begin{array}{l}\text { Size of } \\
\text { corallite } \\
\text { fragment } \\
\text { collected } \\
(\mathrm{cm})\end{array}$} & \multicolumn{4}{|c|}{ Quantity and type of thin sections and number of corallites } \\
\hline & & & Transverse & Corallites & Longitudinal & Corallites \\
\hline $60 \mathrm{C}-25+22 \mathrm{~B}$ & 161095 . & 9 by 9 by 12 & 6 & 1.90 & 6 & 45 \\
\hline $60 \mathrm{C}-28$ & 161091. & 7 by 7 by 10 & 4 & 140 & 2 & 25 \\
\hline $60 \mathrm{C}-29 \mathrm{~A}$ & 161092 . & 7 by 7 by 10 & i. & 35 & 3 & 27 \\
\hline $60 \mathrm{C}-29 \mathrm{~B}$ & 161093. & 7 by 7 by 1.0 & 1 & 18 & 2 & 20 \\
\hline $60 \mathrm{E}-67+2$ & 161094 . & 5 by 8 by 9 & 2 & 55 & 3 & 25 \\
\hline $70 \mathrm{~A}-2+1220 \mathrm{D}$ & 161096 . & 8 by 9 by 10 & 1 & 95 & 1 & 15 \\
\hline $70 \mathrm{~A}-2+1220 \mathrm{~F}$ & 161097. & 8 by 10 by 10 & 1 & 77 & 1 & 14 \\
\hline
\end{tabular}



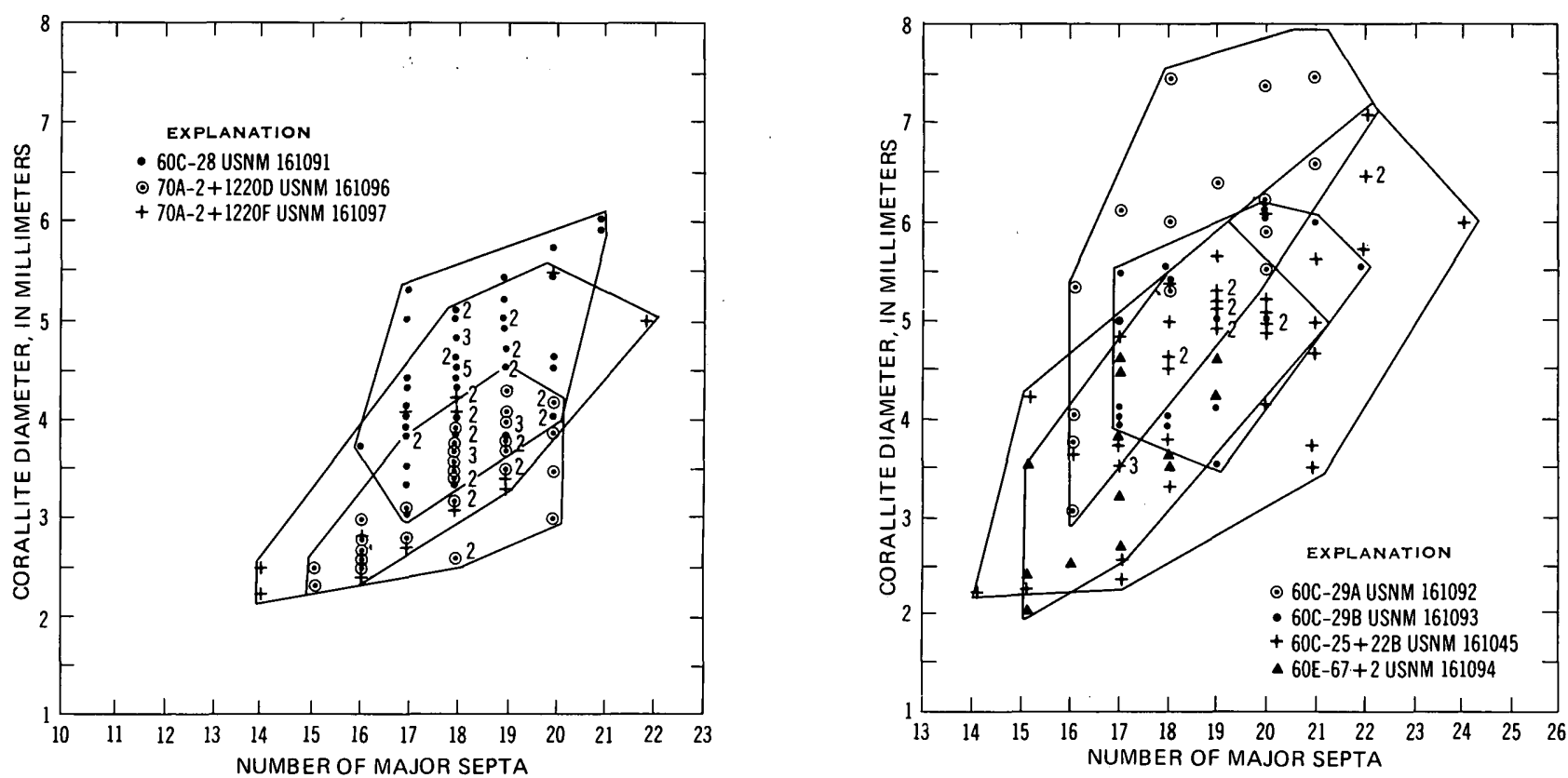

Figure 4.-Graphs showing corallite diameter and number of major septa in Lithostrotion reiseri n. sp. Each unnumbered symbol represents a single corallite; if more than one corallite shows the same diameter and number of septa, the number of similar corallites is shown.

2.2 to $7.2 \mathrm{~mm}$ in diameter and have 14 to 24 long major septa that are continuous through the dissepimentarium. The dissepiments are 0.03 to $0.05 \mathrm{~mm}$ wide in the dissepimentarium. Within the tabularium, the major septa are dilated, 0.25 to $0.35 \mathrm{~mm}$ thick at the tabularium wall, and taper gradually to their distal ends. Minor septa are well developed, long, and continuous through the dissepimentarium and extend 0.2 to $0.35 \mathrm{~mm}$ into the tabularium. The counter septa and, in some specimens, the cardinal septa are continuous with the columella, which is formed by the dilation of the axial end of the counter septum. Other major septa are generally withdrawn from the axial region, except as ridges on the upper surfaces of the tabulae, where the major septa fuse with the columella. The columella is oval in shape and may be from $0.6 \mathrm{~mm}$ long and $0.3 \mathrm{~mm}$ wide to $1.4 \mathrm{~mm}$ long and $0.8 \mathrm{~mm}$ wide.

The dissepiments are arranged in a herringbone pattern. Microstructure is well preserved. The common corallite wall is about $0.2 \mathrm{~mm}$ thick, has a dark central band about 0.02 to $0.03 \mathrm{~mm}$ thick, is formed of calcite deposited at right angles to the wall (fig. $5 e$ ), and can be described as fibrous. The major and minor septa have a very different microstructure from the walls, and the junction of the septa with the wall is distinct. The septal microstructure has been altered by the growth of calcite grains but appears to have been trabecular. Longitudinal thin sections (figs. $5 d, 6 c$ ) show that the tabulae and dissepiments are thin, only about 0.02 to $0.03 \mathrm{~mm}$ thick, and formed by interlocking calcite crystals less than $5 \mu$ in size.

In transverse section, the dissepimentarium is formed by three to six rows of globose dissepiments typically 0.5 by $0.5 \mathrm{~mm}$ as seen in longitudinal sections. The tabulae are generally incomplete and can be divided into an inner and outer series of tabellae. The series next to the dissepiments may be flat or have a slope of $35^{\circ}$, and the inner series has a slope of $15^{\circ}$ to $25^{\circ}$ (figs. $5 d ; 6 b, c$ ). The columella is well developed and persistent. The inner tabellae generally are not strongly arched upwards near the columella.

Paratype USNM 161091 (fig. $6 d, e, f$ ) differs from the holotype by having corallites that show less variation in size, 3 to $6 \mathrm{~mm}$ in diameter with 16 to 21 major septa. Again, all the major and minor septa are continuous through the dissepimentarium. Paratypes USNM 1.61092 and 161093 are very similar to the holotype (fig. $5 c$; fig. $6 a$; fig. $7 c, d$ ). Paratype USNM 161094 (fig. $7 b$ ) is also similar to the holotype except that the major septa are not so strongly dilated in the tabularium.

The specimens USNM 161096 and 161097 (fig. $7 c, d$, and $a$, $g$, respectively) from the Franklin Mountains are characterized by weakly dilated septa and corallites of smaller diameter than those of the holotype.

Remarks.-Lithostrotion reiseri n. sp. shows close affinities to a group of Eurasian cerioid Lithostrotion. The Scottish species L. clavaticum Thomson as described by Hill (1939, p. 178) is very similar to the arctic species. L. clavaticum in

Figure 5.-Lithostrotion reiseri $\mathrm{n}$. sp., all from Itkillik Lake section, $60 \mathrm{C}-1-72$.

a transverse section; $b$, longitudinal section, $\times 3$, holotype, USNM 161095 .

$c$, transverse section, $X 3$, paratype, USNM 161093.

$d$, longitudinal section; $e$, transverse section, $\times 9$, holotype, USNM 161095. 

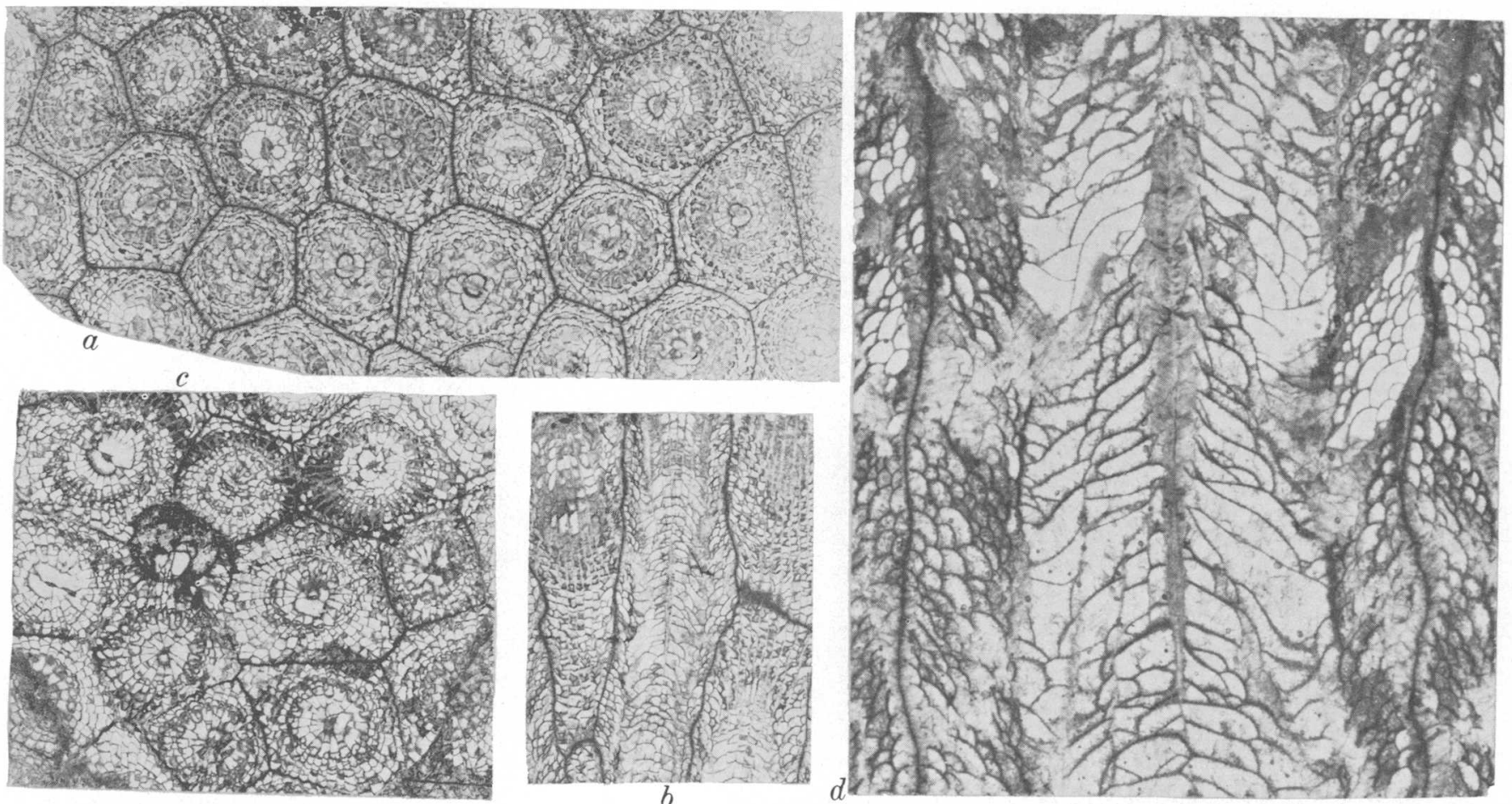

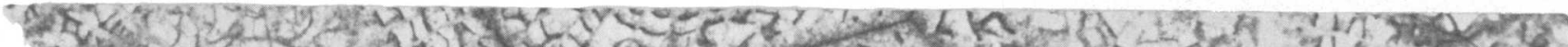

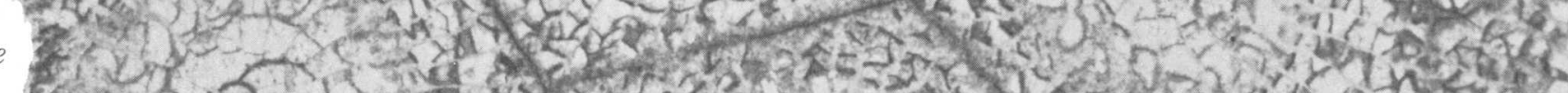

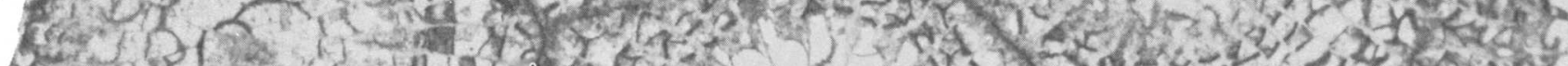

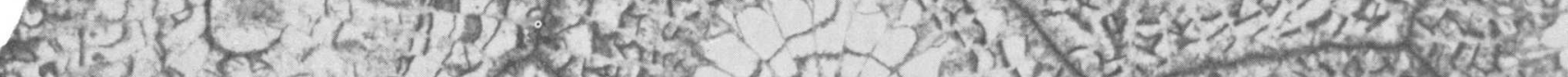

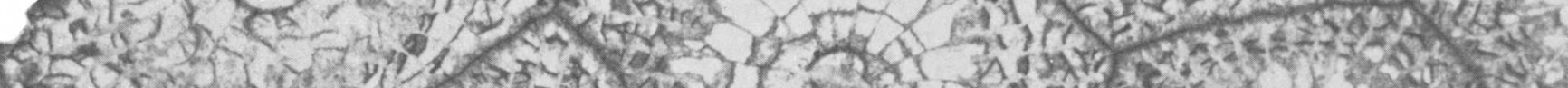

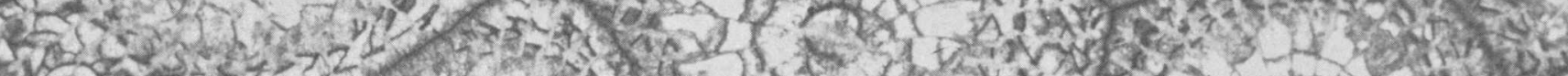

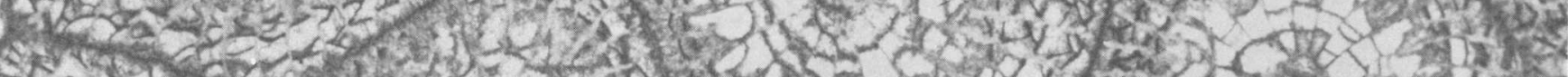

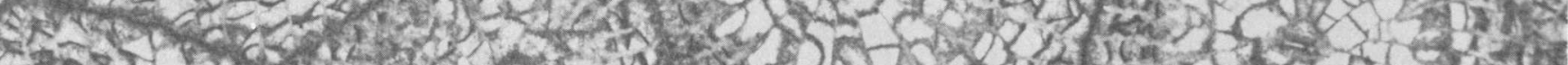

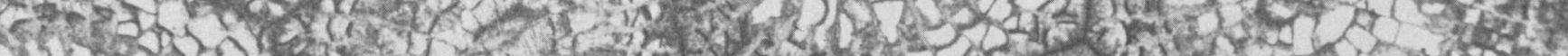

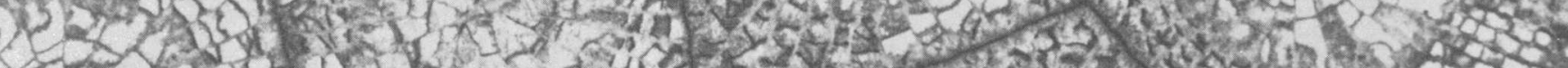

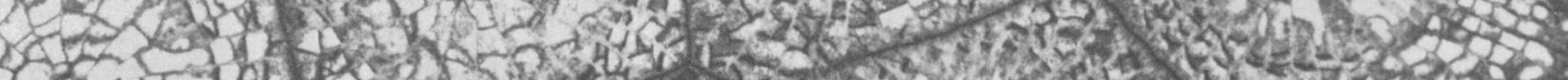

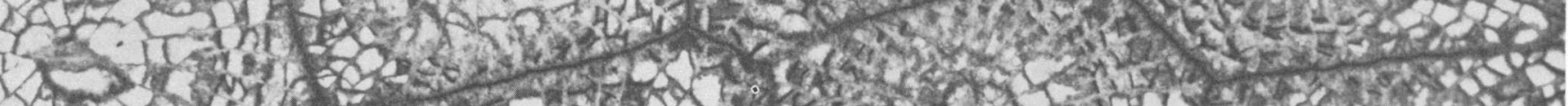

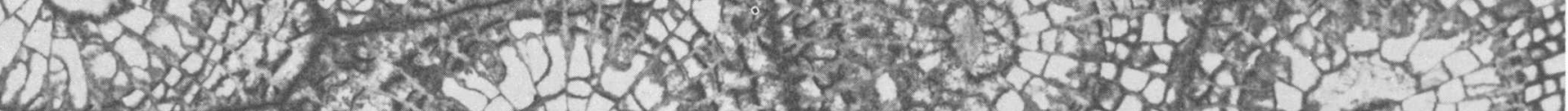

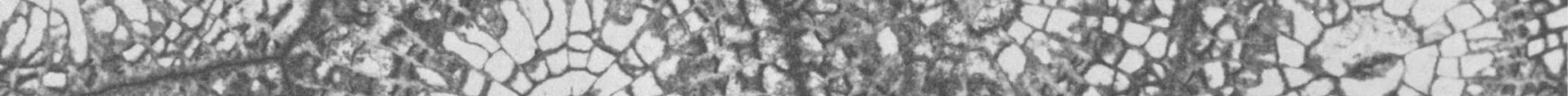

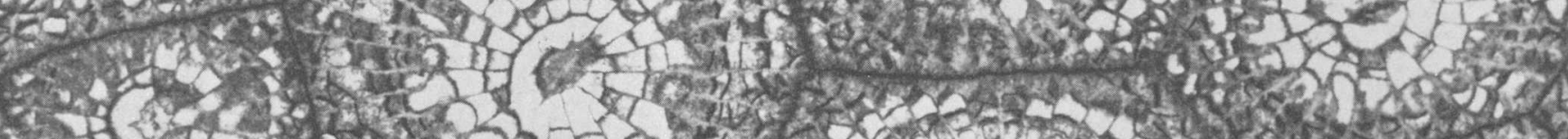

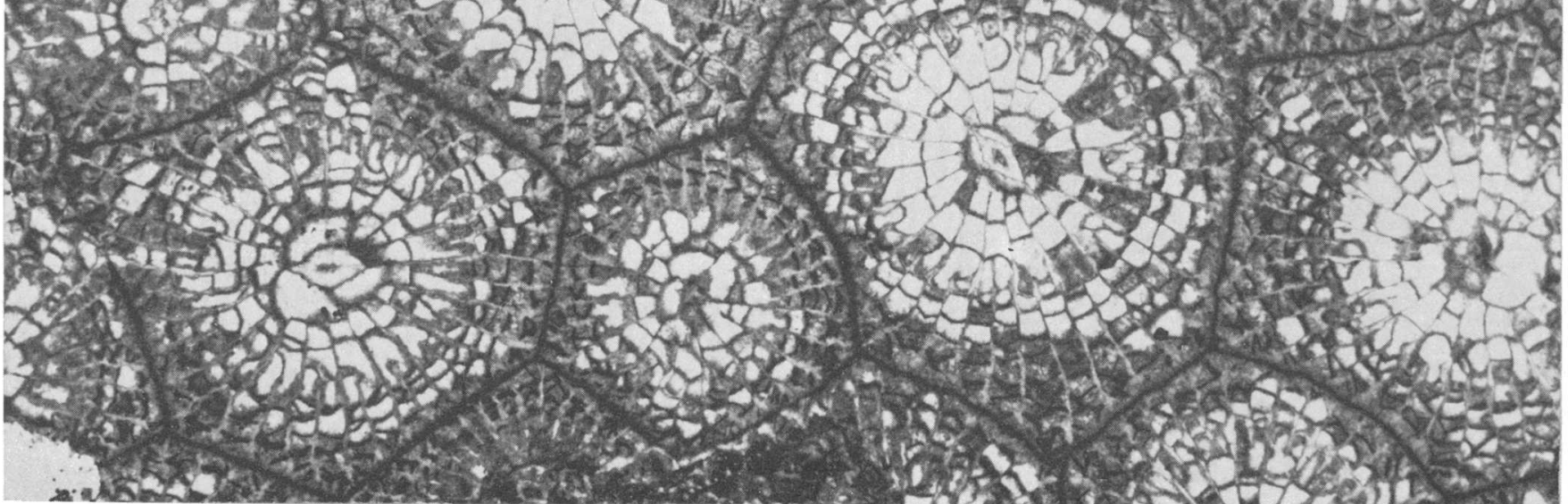

Figure 5. 

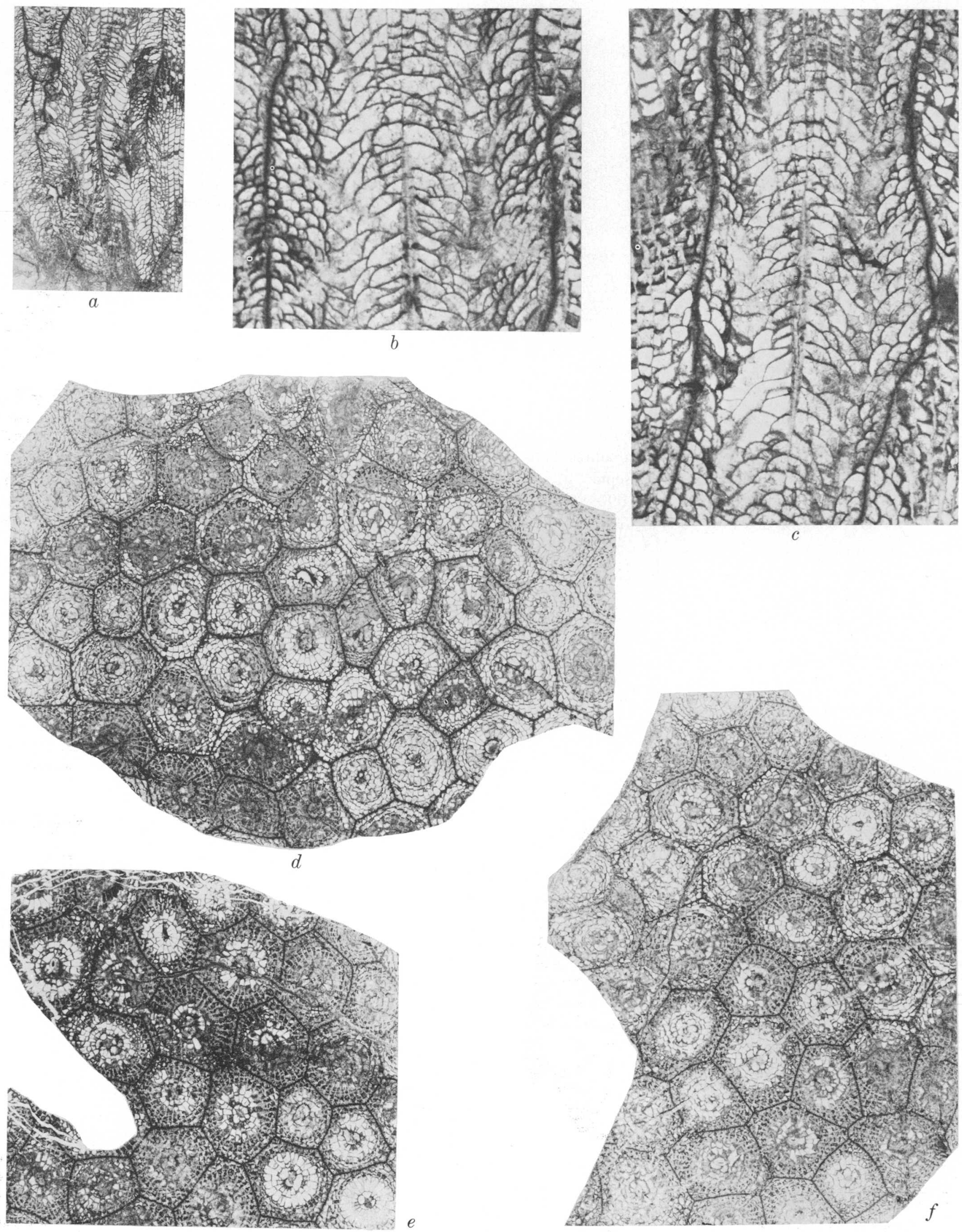

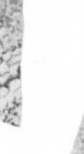

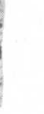

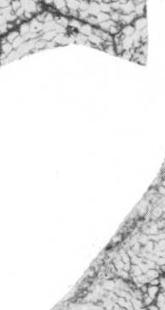

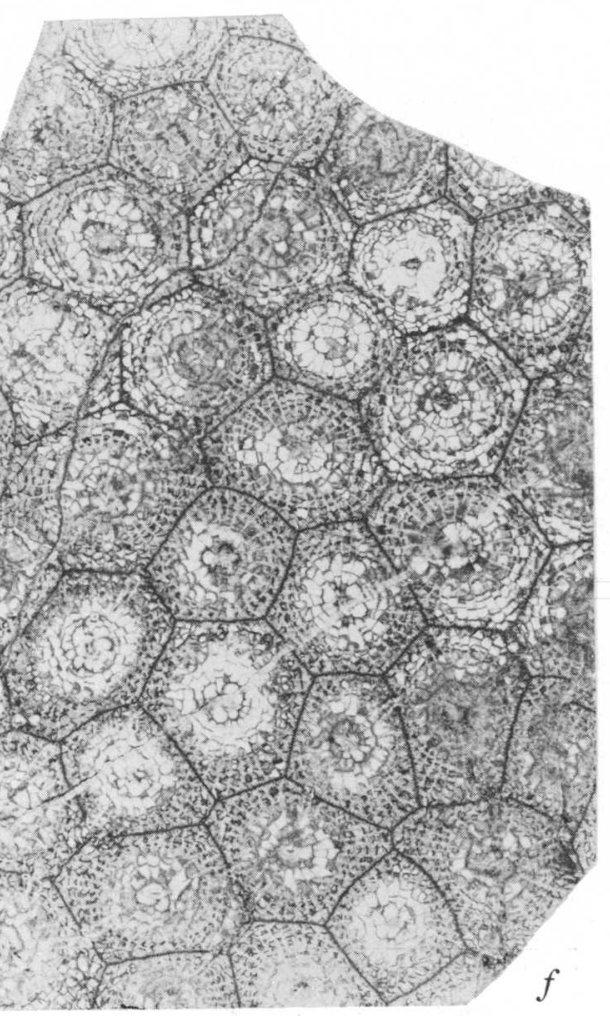

Figure 6. 
Figure 6.-Lithostrotion reiseri $\mathrm{n}$. sp., all from Itkillik Lake section, 60C-1-72.

$a$, longitudinal section, $\times 3$, paratype, USNM 161093.

$b, c$, longitudinal sections, $\times 9$, holotype, USNM 161095 .

$d, e, f$, transverse sections, $\times 3$, paratype, USNM 161091.

contrast to $L$. reiseri has longer major septa and generally complete tabulae. Yü (1933, p. 89-93) described two species of lower Carboniferous corals from China that are also close to L. reiseri. They have similar corallite diameters, but Lithostrotion portlocki Edwards and Haime, var. depasophylloides Yü has only 14 to 15 long major septa and a wider dissepimentarium. Lithostrotion planocystatum $\mathrm{Y} \ddot{\mathrm{u}}$ also has only 13 to 15 major septa, a much wider dissepimentarium, and longer septa. Lithostrotion basaltiforme (Phillips) from the Russian Platform as described by Dobroljubova (1958, pl. 28, figs. $2 \mathrm{a}-2 \mathrm{~b})$ shows only a few traits similar to $L$. reiseri. The immature and smaller corallites in the Russian form are somewhat similar in form to the mature corallites in $L$. reiseri. The Russian specimen typically has larger corallites that are 11 to $16 \mathrm{~mm}$ in diameter with 22 to 26 major septa.

Occurrence.-The holotype USNM 161095 was collected 970 feet below the top of the Itkillik Lake section 60C-1-72 (fig. 8). Paratype USNM 161091 was collected at 1,190 feet, and specimens USNM 1.61 .092 and 1.61093 were collected at 1,220 feet below the top of the same section. All four of the specimens occur in carbonates that contain a large Foraminifera fauna of Meramec (zone 12-13) age (Armstrong and others, 1970). Shell Oil Co.'s stratigraphic section of the Lisburne Group, "Hairy Ridge, 60E-1-99," measured by Richard Emmons, is about 30 miles northeast of the Itkillik Lake section, near the Sagavanirktok River (fig. 9), and has yielded paratype USNM 161094. This specimen was collected about 2,070 feet below the top of the Lisburne Group in limestones that have a rich microfauna of Meramec (zone 12.13) age. Paratypes USNM 161096 and 161097 were collected 1,220 feet above the base of section 70A-2 (Mamet and Armstrong, 1972) in zone 12-13 of the Wachsmuth(?) Limestone. This section is near the junction of Marsh Fork and the Canning River in the Franklin Mountains (fig. 10).

The specimens available for study have been found only in beds associated with a microfauna of Meramec age (zone 12-13). The species has not been found west of the İtkillik River. Extensive coral collections that J. Thomas Dutro and I made from the Lisburne Group of the DeLong Mountains and the Lisburne Hills do not contain Lithostrotion reiseri n. sp.

\section{REFERENCES CITED}

Armstrong, A. K., 1962, Stratigraphy and paleontology of the Mississippian system in southwestern New Mexico and adjacent southeastern Arizona: New Mexico Bur. Mines and Mineral Resources Mem. 8, 99 p., 12 pls. 1970a, Mississippian rugose corals, Peratrovich Formation, west coast of Prince of Wales Island, southeastern Alaska: U.S. Geol. Survey Prof. Paper 534, 43 p., 13 pls., 30 figs.

$1970 \mathrm{~b}$, Carbonate facies and the lithostrotionid corals of the Mississippian Kogruk Formation, DeLong Mountains, northwestern Alaska: U.S. Geol. Survey Prof. Paper 664, 38 p., 1.4 pls., 37 figs.

1972a, Biostratigraphy of Mississippian lithostrotionoid corals, Lisburne Group, Arctic Alaska: U.S. Geol. Survey Prof. Paper 743-A, $28 \mathrm{p}$.

1972b, Pennsylvania carbonates, paleoecology and colonial corals, north flank, eastern Brooks Range, Arctic Alaska: U.S. Geol. Survey Prof. Paper 747. [In press]

Armstrong, A. K., Mamet, B. L., and Dutro, J. T., Jr., 1970, Foraminiferal zonation and carbonate facies of the Mississippian and Pennsylvanian Lisburne Group, central and eastern Brooks Range, Alaska: Am. Assoc. Petroleum Geologists Bull., v. 54, no. 5, p. $687-698,4$ figs.

1971, Lisburne Group, Cape Lewis-Niak Creek, northwestern Alaska, in Geological Survey Research 1971: U.S. Geol. Survey Prof. Paper 750-B, p. B23-B34, 9 figs.

Bamber, E. W., 1966, Type lithostrotionid corals from the Mississippian of western Canada: Canada Geol. Survey Bull. 135, 28 p., 6 pls.

Bowsher, A. L., 1961, The stratigraphic occurrence of some Lower Mississippian corals from New Mexico and Missouri: Jour. Palcontology, v. 35, no. 5, p. 955-962.

Dobroljubova, T. A., 1958, Nizhnekamennogol'nye kolonial'nye chetyrokhluchevye korally Russkoi platformy [Lower Carboniferous colonial tetracorals of the Russian Platform]: Akad. Nauk SSSR Paleont. Inst. Trudy, v. 70, 216 p., 38 pls., 34 figs.

Easton, W. H., and Gutschick, R. C., 1953, Corals from the Redwall limestone (Mississippian) of Arizona: Southern California Acad. Sci. Bull., v. 52, pt. 1, p. 1-27.

Easton, W. H., Sanders, J. E., Knight, J. B., and Miller, A. K., 1958, Mississippian fauna in northwestern Sonora, Mexico: Smithsonian Misc. Colln., v. 119, no. 3, 87 p.

Hill, Dorothy, 1939, A monograph on the Carboniferous rugose corals of Scotland, pt. 2: Palaeontographical Soc. London, 213 p., 11 pls.

Kelly, W. A., 1942, Lithostrotiontidae in the Rocky Mountains: Jour. Paleontology, v. 16, no. 3, p. 351-361, pls. 50, 51, 1 text fig.

Lambe, L. M., 1901, A revision of the genera and species of Canadian Paleozoic corals; the Madreporaria Aporosa and the Madreporaria Rugosa: Canada Geol. Survey, Contr. Canadian Palacontology, v. 4, pt. 2, p. 97-197.

Langenheim, R. L., Jr., and Tischler, Herbert, 1960, Mississippian and Devonian paleontology and stratigraphy, Quartz Spring area, Inyo County, California: California Univ. Pubs. Geol. Sci., v. 38, no. 2, p. 89-150.

Macqueen, R. W., and Bamber, E.W., 1967, Stratigraphy of Banff Formation and lower Rundle Group (Mississippian), sou thwestern Alberta: Canada Geol. Survey Paper 67-47, 37 p., 3 pls., 9 figs.

- 1968, Stratigraphy and facies relationships of the Upper Mississippian Mount Head Formation, Rocky Mountains and foothills, southwestern Alberta: Canadian Petroleum Geology Bull., v. 16, no. 3, p. 225-287, 11 figs.

Mamet, B. L., and Armstrong, A. K., 1972, Lisburne Group, Franklin and Romanzof Mountains, northeastern Alaska, in Geological Survey Research 1972: U.S. Geol. Survey Prof. Paper 800-C, p. C127-C144.

Nelson, S. J., 1960, Mississippian lithostrotionid zones of the southern Canadian Rocky Mountains: Jour. Paleontology, v. 34, no. 1, p. 107-125, pls. 21-25, 3 text figs.

Parks, J. M., 1951, Corals from the Brazer Formation (Mississippian) of northern Utah: Jour. Paleontology, v. 25, no. 2, p. 1.71-1.86, pls. 29-33, 3 text figs. 

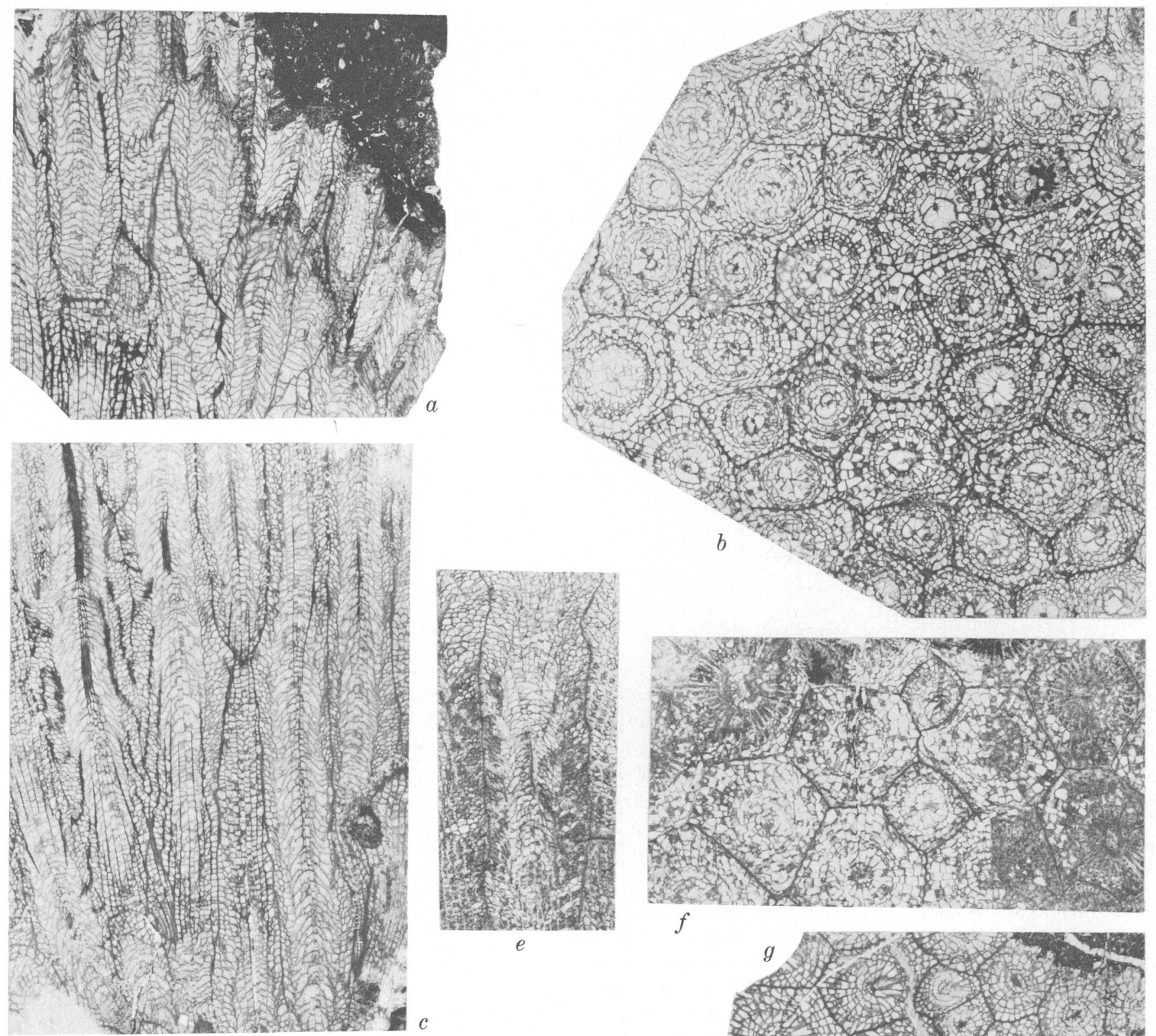

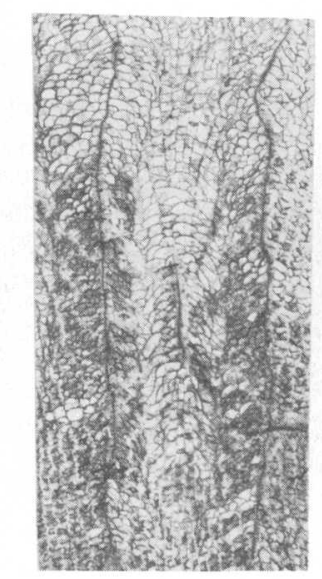

$e$

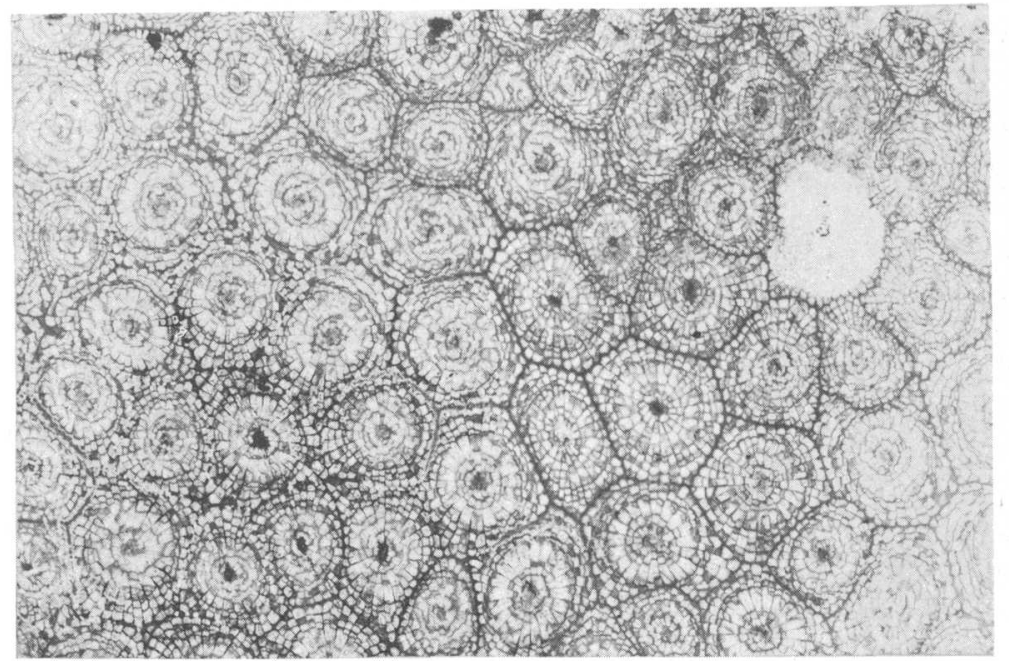

Figure 7.

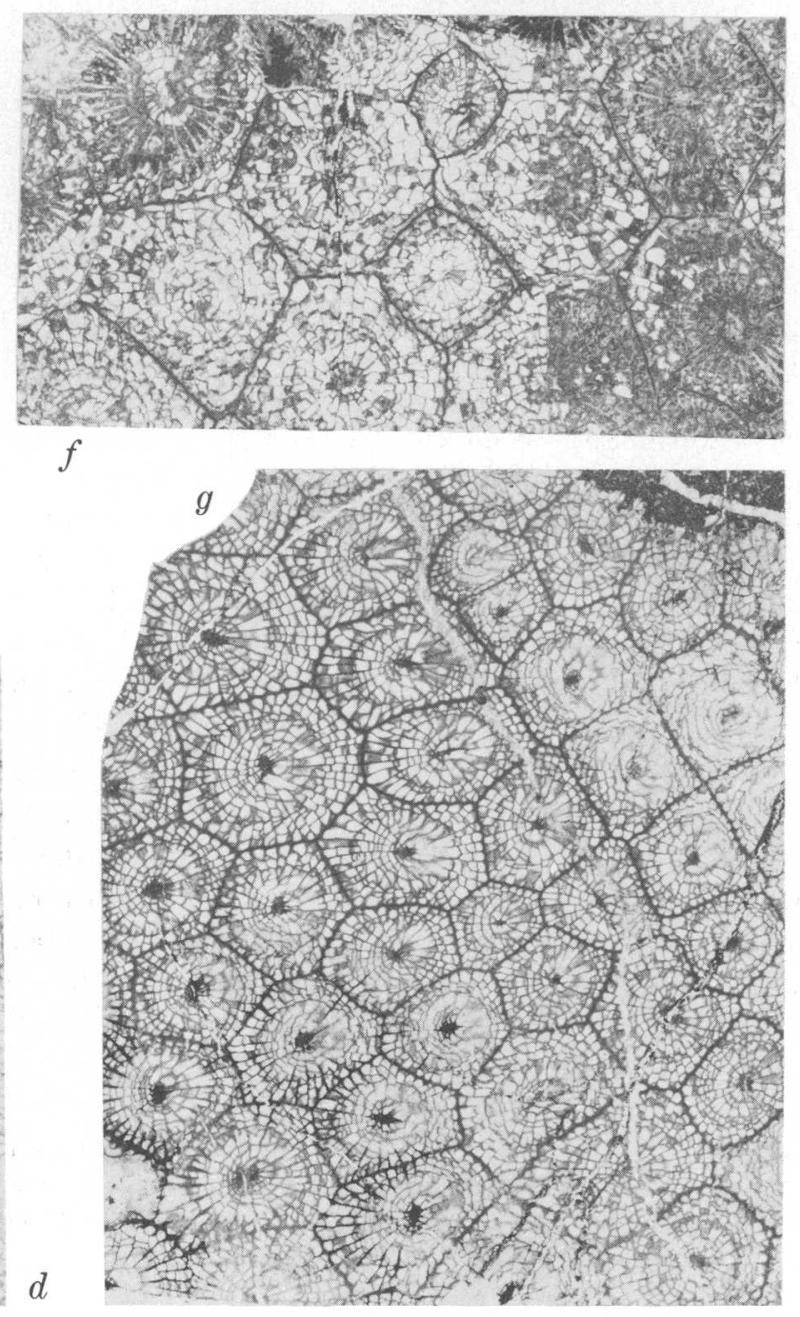




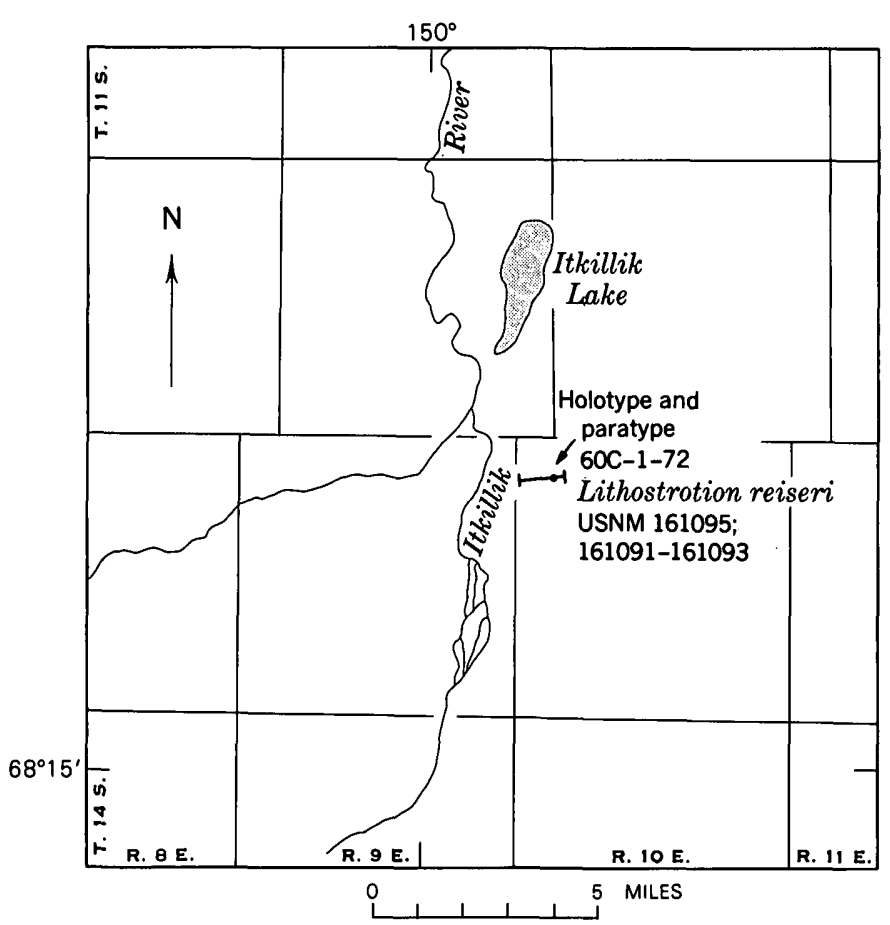

Figure 8.-Map of Itkillik Lake section 60C-1-72, showing collection localities of the holotype and paratypes of Lithostrotion reiseri n. sp.

Sando, W. J., 1960, Corals from well cores of Madison group, Williston basin [Montana]: U.S. Geol. Survey Bull. 1071-F, p. 157-190 [1.961].

1963, New species of colonial rugose corals from the Mississippian of northern Arizona: Jour. Paleontology, v. 37, no. 5, p. 1074-1079, pls. $145,146$.

— 1.969, Corals, in McKee, E. D., and Gutschick, R. C., eds., History of Redwall Limestone in northern Arizona: Geol. Soc. America Mem. 114, p. 257-342, pls. 29-40.

Sando, W. J., Mamet, B. L., and Dutro, J. T., Jr., 1969, Carboniferous megafaunal and microfaunal zonation in the northern Cordillera of the United States: U.S. Geol. Survey Prof. Paper 613-E, 29 p., 7 figs.

Stensaas, L. J., and Langenheim, R. L., Jr., 1960, Rugose corals from the Lower Mississippian Joana Limestone of Nevada: Jour. Paleontology, v. 34, no. 1, p. 179-188, 10 figs.

Sutherland, P. K., 1958, Carboniferous stratigraphy and rugose coral faunas of northeastern British Columbia: Canada Geol. Survey Mem. 295,177 p., 33 pls., 4 figs.

Yii, C. C., 1933, Lower Carboniferous corals of China: China Geol. Survey, Palaeontologica Sinica, ser. B, v. 12, pt. 3, 211 p., 24 pls.

Figure 7.-Lithostrotion reiseri n. sp. $a, c, d, g$, from Marsh Fork section $70 \mathrm{~A}-2$; $b$, from Hairy Ridge section $60 \mathrm{E}-1.99$; and $e, f$, from Itkillik Lake section 60C-1-72.

$a, g$, longitudinal and transverse sections, $\times 3$, paratypes, USNM 161097.

$b$, transverse section, $\times 3$, paratype, USNM 161.094 .

$c, d$, longitudinal and transverse thin sections, $\times 3$, paratype, USNM 161096.

$e, f$, longitudinal and transverse thin sections, $\times 3$, paratype, USNM 161092.

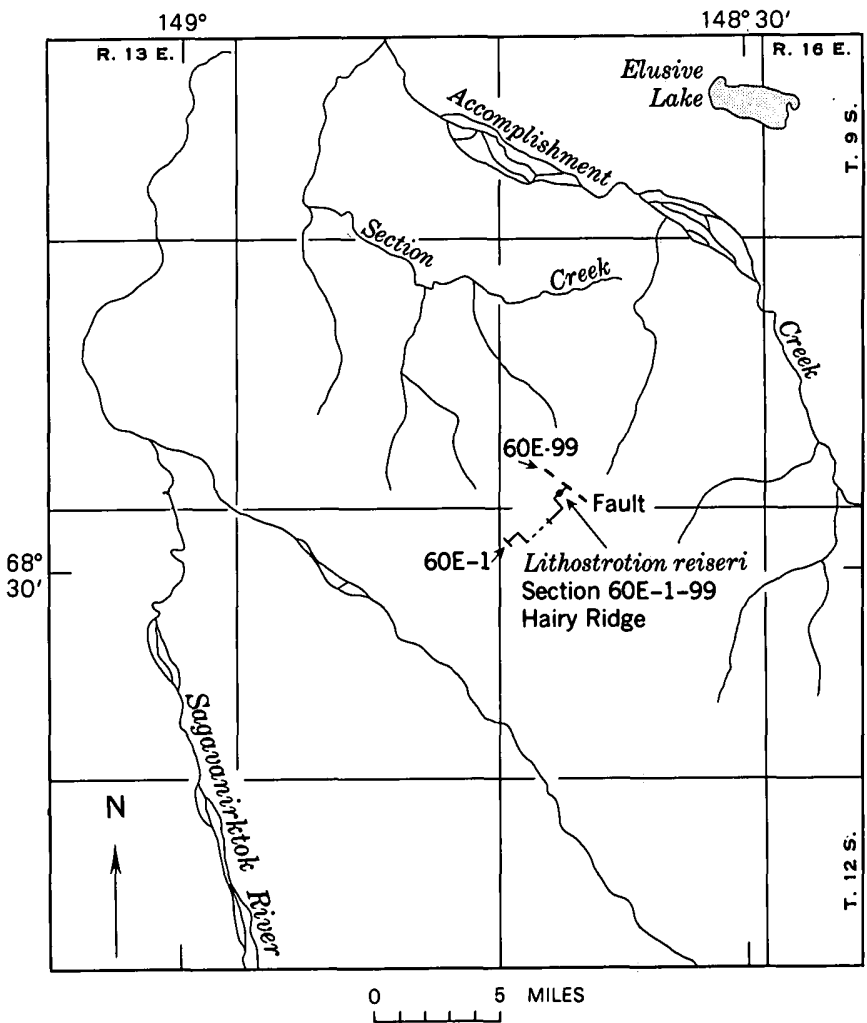

Figure 9.-Map of Hairy Ridge section 60E-1.99, showing collection localities of the paratypes of Lithostrotion reiseri n. sp.

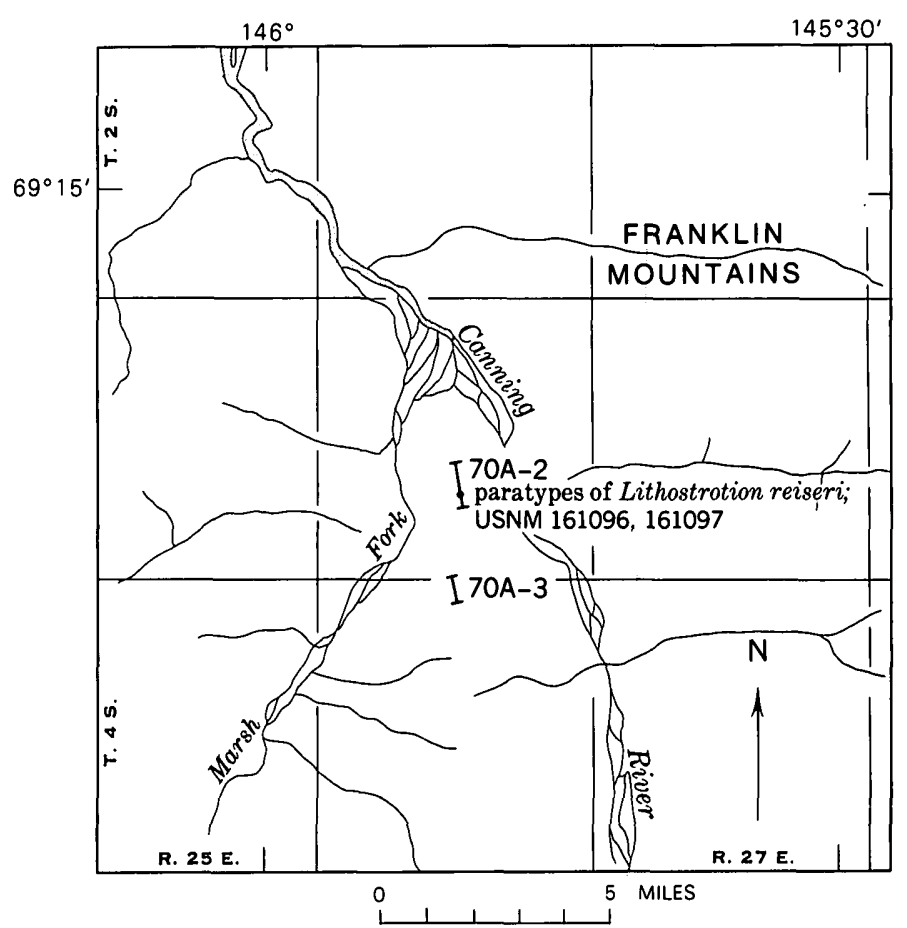

Figure 10.-Map of Marsh Fork section 70A-2, showing collection localities of paratypes of Lithostrotion reiseri n. sp. 



\title{
A SECOND SPECIMEN OF PARAHYUS VAGUS MARSH, 1876
}

\author{
By G. EDWARD LEWIS, Denver, Colo.
}

\begin{abstract}
The occurrence of the second known specimen of Parahyus vagus, from the Tepee Trail Formation, Wyoming, is recorded. As the first specimen was reported from the lower Eocene, this second occurrence casts doubt on the supposed age ranges of both Parahyus and the Tepee Trail.
\end{abstract}

\section{PALEONTOLOGY}

In 1876 (p. 402), Marsh named and described Parahyus vagus, a palaeodont artiodactyl hoofed animal very remotely related to the swine, on the basis of a right mandibular ramal fragment with alveolus of $\mathrm{P}_{2}$, root-stump of $/ \mathrm{C}, \mathrm{P}_{3-4}$, and $M_{1-3}$ (Yale Peabody Museum No. 10972) "from the lower Eocene of Wyoming." The purpose of the present report is to record the discovery of the second known specimen of Parahyus. It adds nothing to our knowledge of the morphology of the genus because the entire specimen consists of a left mandibular ramal fragment with $\mathrm{P}_{3-4} \mathrm{M}_{1-3}$ (fig. 1) but no skull or other parts of the skeleton. It is a mirror image of all but the anteriormost, toothless portion of the type of $P$. vagus. The specimen was found by J. D. Love in 1.936, collected by me at his request in 1938, and, with pertinent field records, added to the collections of the Yale Peabody Museum where it has since been mislaid or lost and so the specimen is not available to me for comparisons and measurements at this time. Fortunately, I had duplicate photographic prints that have been used for the illustrations in figure 1 of this report.

\section{STRATIGRAPHY AND AGE}

I am indebted to J. D. Love for the opportunity to record the discovery of this rare specimen, and for the following information about the locality (oral commun., June 8, 1972): the specimen was found in 1936 in the type section of the Tepee Trail Formation (Love, 1939, p. 74), T. 44 N., R. 104 W., Fremont County, Wyo., on the top of the high river cliffs on the east side of East Fork of the Wind River, 10 feet 8 inches above the base of unit 30 as described in the published type section.

The holotype was collected by J. Heisey for Marsh in 1876, and the tray label reads "Lower Eocene Washakie?, Cory- phodon zone, Wyoming, Bitter Creek Station." This usage of the stratigraphic name "Washakie" is the correct, original usage of Hayden (1869, p. 90, with the spelling "Washakee"), who later (1877, p. 181-183) stated that he "named the Washakie $* * *$ which is probably the same as *** the Wasatch." The usage of Wood and others $(1941$, p. 36, pl. 1) is a misuse of Hayden's name. No other specimen positively referable to this genus has ever been described.

Love $(1939$, p. 78$)$ "provisionally correlated *** the Tepee Trail formation *** with at least part of the Uinta formation of Upper Eocene age" but stated that "on the basis of the few fragmentary fossils, specific age determinations and long-range correlations are not justified". Wood and others (1941, p. 33, pl. 1.) and most writers since 1941 have listed the Tepee Trail as upper Eocene equivalent to the Uinta without the careful reservation of Love's original description. In the field, while the Tepee Trail specimen was still largely in the enclosing rock with the dentition only partly visible, and with the provisional upper Eocene stratigraphic position in mind, I had guessed that the specimen might be referable to the characteristic late Eocene genus Achaenodon. When, after Love's report (1939) had gone to press, the Tepee Trail specimen was prepared for study and identification, it cast doubt on the provisional upper Eocene correlation of the Tepee Trail, and also on the supposed lower Eocene stratigraphic position of the type of Parahyus vagus, because it was clear that the Tepee Trail specimen could only be a Parahyus, very close morphologically to the genotype.

Gazin, in his review of the Eocene Artiodactyla (1.955, p. $38,42-43)$ argued that (1) he "cannot believe *** the type ${ }^{* *}$ described by Marsh as coming from the Lower Eocene of Wyoming" really came from lower Eocene rocks because "Parahyus vagus is clearly and in every respect at a stage of development intermediate between Bridger Helohyus lentus and *** Uinta B Achaenodon insolens. (2) Moreover, during an intensive field program $* * *$ no further evidence has been discovered of such a form in the" lower Eocene, but (3) he added that "Parahyus vagus is apparently, though not necessarily, too advanced for Bridger $D^{* * *}$." His first observation is good professional opinion and fully correct, but not a conclusive argument for relative stratigraphic position; all faunas, including today's living animals, show contem- 

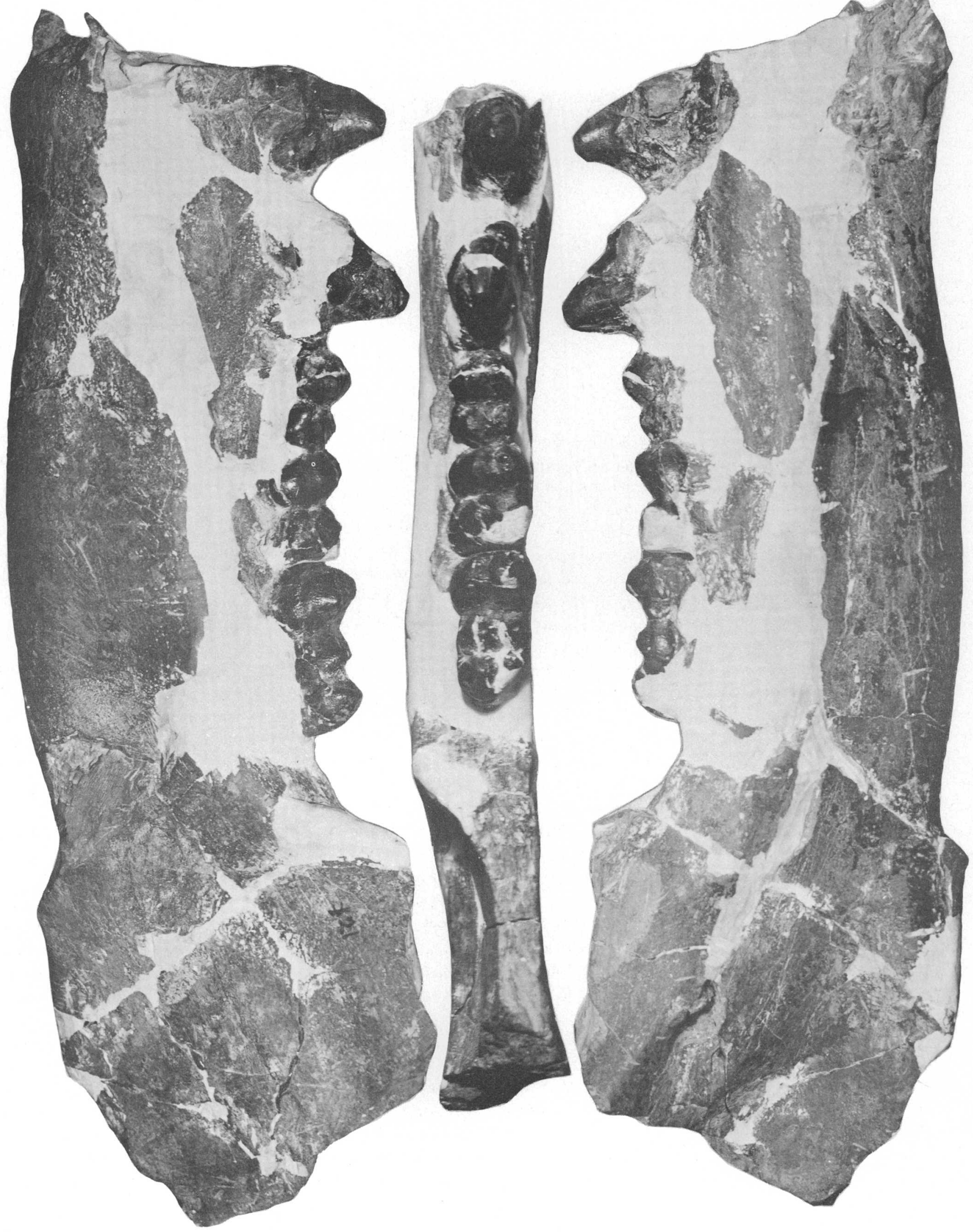

Figure 1. 
Figure 1.-Fragment of left mandibular ramus of Parahyus vagus, about natural size. Left, labial-buccal view; center, occlusal view; right, lingual view.

porary morphologically primitive and advanced genera. His second observation is correct negative evidence but even more inconclusive because for the 97 years preceding the present report, more intensive field programs in richly fossiliferous middle and upper Eocene rocks have failed to report the positive evidence of upper or middle Eocene specimens of Parahyus. His third observation speculates that Parahyus might occur in rocks of middle Eocene stratigraphic position; I would concur in this speculation. But Marsh's information is all the direct evidence we have had to the present time.

It seems impossible that the Tepee Trail Formation could be lower Eocene, whether or not the type of Parahyus vagus did in fact come from lower Eocene rocks: underlying the Tepee Trail is the Aycross Formation, which has yielded vertebrate fossils of middle Eocene (Bridger fauna) age according to Love (1939, p. 70, 73). Possibly the Tepee Trail and its Parahyus vagus are either of post-Aycross middle Eocene age or of late Eocene age as suggested by Love.
The stratigraphic and age ranges of Parahyus are still moot, but Love's specimen of Parahyus vagus establishes an upper stratigraphic limit for this genus above the lower Eocene. The radiometric age range may not be great: J.D. Obradovich has stated (oral commun., June 15, 1972) that the Tepee Trail cannot be younger than 46 m.y. B.P., so only 3 m.y. separates it from the Wasatch Formation.

\section{REFERENCES CITED}

Gazin, C. L., 1955, A review of the upper Eocene Artiodactyla of North America: Smithsonian Misc. Colln., v. 128, no. 8, 96 p.

Hayden, F. V., 1869, Preliminary field report [third annual] of the United States Geological Survey of Colorado and New Mexico: Washington, U.S. Govt. Printing Office, 155 p.

1877 , Notes on some artesian borings along the line of the Union Pacific Railroad in Wyoming Territory: U.S. Geol. and Geog. Survey Terr. Bull. 3, p. 181-185.

Love, J. D., 1939, Geology along the southern margin of the Absaroka Range, Wyoming: Geol. Soc. America Spec. Paper 20, $134 \mathrm{p}$.

Marsh, O. C., 1876, Notice of new Tertiary mammals, V: Am. Jour. Sci., ser. 3, v. 12, p. 401-404.

Wood, H. E., 2d, Chaney, R. W., Clark, John, Colbert, E. H., Jepsen, G. L., Reeside, J. B., Jr., and Stock, Chester, 1941, Nomenclature and correlation of the North American continental Tertiary: Geo' Soc. America Bull., v. 52, no. 1, p. 1-48. 



\title{
THE CONCEPT OF GROWTH AND MATURITY OF ORE-STAGE PYRITE IN ROLL-TYPE URANIUM DEPOSITS
}

\author{
By C. G. WARREN ${ }^{1}$ and H. C. GRANGER, \\ Fort Collins, Colo., Denver, Colo.
}

\begin{abstract}
Roll-type uranium deposits contain both ore-stage pyrite and preore or diagenetic pyrite that was present in the host rock before the deposits began to form. Ore-stage pyrite forms as the result of redistribution and accretion from the preore pyrite. Accretion of the ore-stage pyrite seems to be governed by natural laws that limit its concentration to only a few times the concentration of the preore pyrite. Accumulations of ore-stage pyrite build up along the leading edge of a supergene oxidation zone which spreads through the host rocks, literally pushing the ore deposits ahead of it. The ore-stage pyrite probably progresses much as a wave that first grows to a nearly fixed amplitude and thereafter is steadily maintained as the mature deposit continues to advance.
\end{abstract}

Roll-type uranium deposits have now been recognized and studied for more than a decade but, although much is known about their size, shape, geologic setting, element distribution, and mineralogy, some aspects of their genesis remain unknown or clouded in controversy. Pyrite and sparse marcasite are always associated with the uranium minerals in these deposits, and it is the chemical and (or) isotopic behavior of iron and sulfur that have yielded the most definitive information about the depositional geochemistry and genesis of roll-type deposits. In this paper we examine some additional implications that are provided by the distribution pattern of the sulfide minerals, which will hereafter be referred to collectively as pyrite.

A concept of maturity followed by a steady-state process in the genesis of roll-type uranium deposits has been developed through a series of earlier papers (Granger and Warren, 1969; Warren, 1971, 1972) but may have been inadequately explained and justified. One purpose of this paper, therefore, is to show how the pyrite accumulations associated with rolltype deposits might have evolved. The exact chemical or biogenic reactions involved do not have to be specified, because this concept deals largely with the quantitative efficiency of the process and not with details of the process itself.

Roll-type uranium deposits now constitute one of the world's principal resources of uranium ore and are known to

\footnotetext{
' Colorado State University.
}

occur in Wyoming (Harshman, 1962, 1966, 1970; Armstrong, 1970; Melin, 1964, 1969; King and Austin, 1966; Davis, 1969; Bailey, 1969), Texas (Eargle and Weeks, 1968; Harshman, 1970), New Mexico (Shawe and Granger, 1965), and at several places in the Soviet Union (Germanov, 1960; Lisitsyn and Kuznetsova, 1967; Kholodov and others, 1961; Kashirtseva, 1964). Although rather thorough descriptions and speculation regarding the genesis of the deposits are included in the cited reports, it may be well to review, briefly, the salient features common to most of the deposits.

\section{GENERAL DESCRIPTION OF DEPOSITS}

With very few exceptions (Kholodov and others, 1.961) the host rocks are gently dipping, permeable, fluvial sandstone strata underlain and overlain by less permeable strata (fig. 1). Where unaltered, they typically contain small quantities of organic matter that may range from finely disseminated kerogenlike material to coaly tree limbs, trunks, and other fragmental plant fossils. At least some of the deposits of the U.S.S.R. are said to be in strata that contain petroleum or petroleum residues.

Before the deposits began to develop, the host rocks invariably contained from a few tenths percent to 2 percent disseminated pyrite. This pyrite is presumed to have formed during diagenesis by biogenic bacterial reduction of sulfate to sulfide species. Indeed, only a biogenic process seems adequate

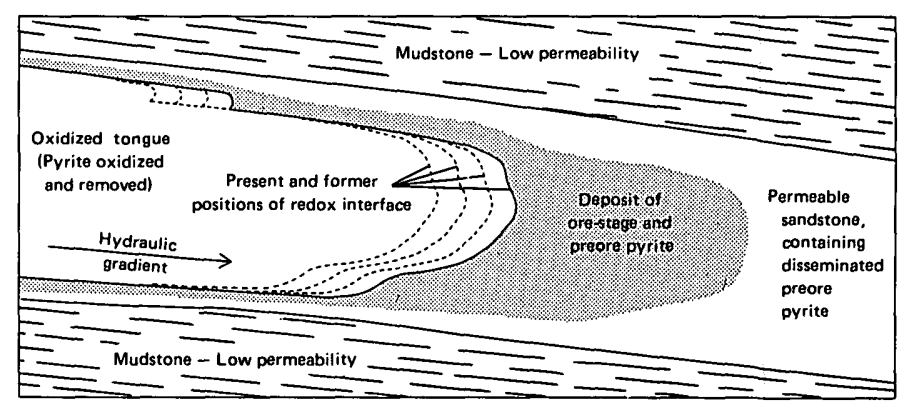

Figure 1.-Some characteristics of a roll-type deposit. 
to explain thoroughly disseminated sulfide minerals produced solely at low temperature during diagenesis of a sedimentary rock. Although this pyrite may make up only a small part of the unaltered host rock, its importance to the processes that form roll-type uranium deposits should not be underestimated.

The uranium deposits are all closely associated with an altered zone within the host rocks. This is typically a large, irregular tongue-shaped mass in which most of the original pyrite has been destroyed by oxidation. The "base" or updip part of the tongue is now exposed at the surface or can be inferred to have once cropped out-a characteristic that establishes an inferential relation between the oxidized rock and oxygen-rich meteoric waters.

An envelope of anomalously pyritic rock virtually encloses each oxidized tongue like a huge sack (fig. 1). This envelope can range in thickness from a few inches along the upper and lower surfaces of the tongue to 200 feet along the bordering edges of the tongue. Much of the pyritic envelope is also uraniferous, and uranium ore bodies are distributed within the thicker parts of the envelope along the margins or "front" of each tongue, where the surface of the tongue-the redox interface-rolls sharply across the layers of stratification.

Oxidation of the host rock within the tongue (in terms of the oxidation of pyrite) was presumably caused by an extension of the weathering process to considerable depth through downward percolation of oxygen-bearing meteoric water. Orestage minerals in the envelope surrounding the tongue are believed to have migrated in these waters by means of a continuous cyclic process of dissolving and then reforming a short distance down the hydraulic gradient. The prevailing opinion is that the ore body accumulated and migrated along the leading edges of the tongue as it expanded into the host rocks.

Most tongues are only a few feet to a few tens of feet thick, but they can have an areal extent measurable in square miles. If we assume that the oxidized rock within the tongue once contained pyrite commensurate with the unoxidized, nonuraniferous host rock which contains even the smallest amounts of pyrite, it is obvious that vast amounts of pyrite have been removed from the oxidized tongue. In most places, even near and in uranium ore bodies, the richest representative samples from the pyritic envelope contain only a few times more pyrite than the pristine unoxidized host rock well away from the tongue, and in many places the added secondary pyrite is nearly imperceptible. Definitive data, admittedly, are scanty for rock at some distance from uranium deposits, and there is little reliable information to indicate whether all parts of the roll front (the rounded margins of the tongue) are anomalously pyritic. For this reason we shall direct our appraisal principally to the pyrite associated with the uranium deposits, although presumably pyrite elsewhere along the oxidized envelope follows the same geochemical pattern of genesis and distribution.

The altered tongue once contained more than enough pyrite to account for all the ore-stage pyrite now present; however, the same relation may not hold for other ore-stage components such as uranium and selenium. An intrinsic source within the host rocks seems to be a reasonable assumption for pyrite, but an extrinsic source may provide a better explanation for some of the other ore-stage minerals. The genesis of ore components other than pyrite and related sulfide minerals, however, is not within the scope of this paper.

If the pyrite redistribution process was heterogeneous, varying widely in type or efficiency of reactions from place to place, we might expect to see enormous concentrations of pyrite at some places, contrasted with virtually no anomalous concentration elsewhere. Some controlling mechanism must have operated during redistribution of the pyrite to permit a severalfold concentration but prevent the accumulations from building up until the pore spaces were blocked. The occurrence of generally low-grade accumulations of pyrite along the roll front indicates that only a part of the pyrite removed from the oxidized tongue has been redeposited.

\section{MATURITY AND THE STEADY-STATE CONCEPT}

The assumption is, then, that the ore-stage pyrite in the envelope was derived either solely or largely by a redistribution process, while the grade remained fairly constant and seemingly showed no correlation to the size of the oxidized zone; it seems probable that the deposits of ore-stage pyrite first built up to a somewhat uniform size and grade and then continued to move in advance of the oxidized tongue without undergoing significant changes. This implies that throughout most of its active history the advance of the oxidized tongue continually destroyed and lost an amount of pyrite equal to the diagenetic pyrite but figuratively pushed a "bow wave" of redistributed pyrite ahead of it. The distance over which pyrite is anomalously concentrated can be thought of as a cycle. Accordingly, a fundamental concept of roll-type ore formation was proposed by Warren (1971): when the pyrite being oxidized and lost to redeposition in each cycle is equal to the pyrite already present in the rock, the amount of sulfide sulfur in the deposit neither increases nor decreases, but remains constant, cycle after cycle and over extended distances and periods of time. When a deposit first begins to accumulate, the pyrite lost in each cycle must be less than the pyrite originally present in the rock. Although the proportion of pyrite destroyed and lost in each cycle may not change, larger and larger actual quantities of pyrite are lost as the deposit grows in size. When the lost pyrite equals the original pyrite, the deposit may be said to be mature and will maintain this steady state no matter how far it moves. If the efficiency of transfer and redeposition of pyrite remains constant, maturity is inevitable. It is this principle that we will examine further. Speculation on the mechanism(s) of pyrite redistribution must then be compatible with these findings.

We continue to discuss the deposits as if pyrite being oxidized at the roll front were the only source of components for the reconstituted pyrite. The steady-state concept can 
apply, however, even if the oxidizing solutions should introduce components which can recombine as pyrite. When maturity is reached, in this situation, the total loss of components from oxidized rock must include an amount equal to both the preore pyrite and the introduced material.

Figure 2 illustrates what happens when pyrite is oxidized at the redox interface and some fraction of it is repeatedly

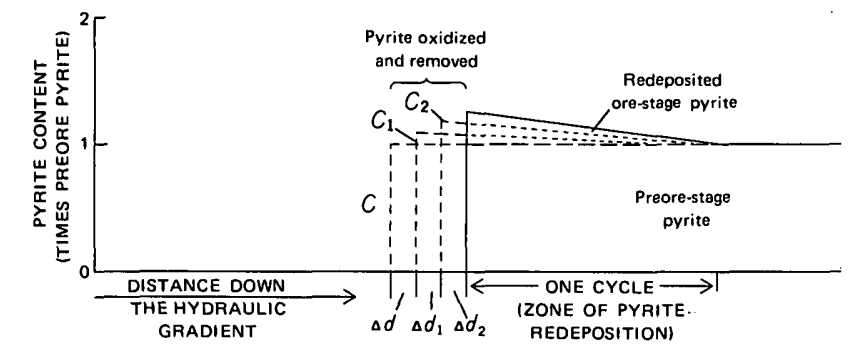

Figure 2.-Graph depicting initial growth stages of ore-stage pyrite in a roll-type deposit. Refer to text for explanation.

transported and redeposited in the ore zone. It depicts the early stages of a process that is 50-percent efficient; that is, as the pyrite is oxidized over a distance $\Delta d$, half of it is redeposited and half is lost. Losses can occur either if some components of pyrite become oxidized and lag behind in the oxidized zone or if they become soluble and are swept out of the system. Presumably, the rate at which pyrite is redeposited is a function of the concentrations, in solution, of the active components of pyrite. These concentrations should be greatest just beyond the redox interface and continually diminish as deposition proceeds. Hence, at the inception of a roll, the first pyrite oxidized can be represented graphically (fig. 2) by the rectangle whose area is $C \Delta d$; almost simultaneously, the first pyrite-redeposited becomes the flat-lying triangle with vertical leg, $C_{1}$. The next tiny advance of the redox interface causes the oxidation of the preore pyrite in $C \Delta d_{1}$, and also a little of the ore-stage pyrite deposited during the previous step. The pyrite redeposited as a result of the $d_{1}$ advance of the redox interface can be represented by the quadrilateral with one side equal to $C_{2}$, and which directly overlies the triangular area representing pyrite deposited in the previous step.

At each step the amount of ore-stage pyrite oxidized increases slightly, and the amount of pyrite redeposited increases correspondingly. Concurrently, the pyrite lost during each step increases, and eventually (fig. $3 A$ ) the amount of pyrite lost is virtually equal to the preore pyrite being oxidized. The deposit can then be said to have attained maturity. Subsequently, as the redox interface continues further, the amount of ore-stage pyrite oxidized equals the amount of ore-stage pyrite being redeposited. The mature deposit can be said to move according to a steady-state process. As ore-stage pyrite is removed from one part of the deposit, it is continually replenished by deposition in other parts of the deposit. We are, of course, speaking of equivalent
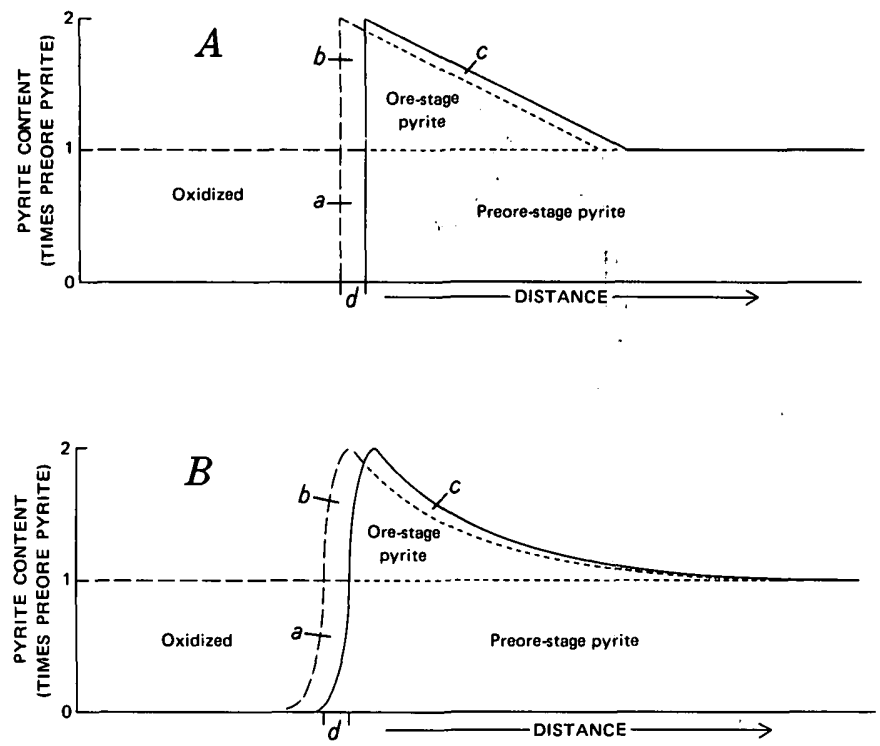

Figure 3.-Graphs depicting ore-stage pyrite cycle in a mature roll-type deposit. Arbitrary efficiency of redeposition is $\mathbf{5 0}$ percent. Area $a$, preore pyrite oxidized but not redeposited; area $b$, ore-stage pyrite oxidized; area $c$, redeposited pyrite; area $b=$ area $c . A$, Representation that must follow from growth pattern depicted schematically by figure 2. $B$, More probable idealized pattern at maturity where pyrite redeposited is related to concentration of components remaining in solution. Efficiency of the process is the ratio between total pyrite redeposited and total pyrite oxidized.

$$
\begin{aligned}
\text { Efficiency } & =\frac{c}{a+b}, \text { Substituting } b \text { for } c, \\
& =\frac{b}{a+b}, \text { or } \\
& =\frac{\text { Maximum ore-stage pyrite }}{\text { Maximum total pyrite }}
\end{aligned}
$$

amounts of oxidized pyrite and transported pyrite, it being immaterial to the process whether a molecule deposited as ore-stage pyrite was previously derived from ore-stage pyrite or preore pyrite.

Efficiency-the ratio of pyrite continually being redeposited to the pyrite dissolved-is a function of the processes involved. If the process is 50-percent efficient, as shown in figures 2 and 3 , the maximum (preore plus ore-stage) pyrite content at maturity is double the preore pyrite concentration. If twothirds of the oxidized pyrite is reprecipitated, a maximum pyrite content three times the preore pyrite content is maintained. If the efficiency is 75 percent, the pyrite buildup is fourfold, and so on. This can be represented by the formula:

$$
P_{\mathrm{t}}=P_{\mathrm{p}} /(1-f)
$$

where

$P_{\mathrm{p}}$ is the preore pyrite content, $f$, or efficiency, is the fraction of pyrite redeposited relative to that dissolved in each cycle, and

$P_{\mathrm{t}}$ is the total pyrite concentration at the redox interface. 
The formula merely says that, after maturity is achieved and as the pyrite is continuously dissolved at the redox interface, some fraction of that pyrite will be continuously and commensurately redeposited in advance of the interface. That fraction is $f$ and the amount redeposited is $f P_{t}$. The pattern of redistribution of the ore-stage pyrite is immaterial. Derivation of the same formula from a variety of hypothetical patterns of pyrite distribution can be proved mathematically; the principle is shown graphically in figure 2 . If the efficiency of the process of dissolution and redeposition remains constant and if the amount of pyrite being dissolved minus the pyrite being redeposited is equal to the preore pyrite, the requirements for a steady-state system are satisfied.

A simplified graphic presentation like figure 2 does not accurately represent the natural situation. For example, figure 2 suggests that the rate of redeposition decreases with distance from the oxidation front. Figure 2 is probably a reasonably valid representation, because the amount of pyrite redeposited is expected to be proportional to the concentration of components remaining in solution. Continued increments as shown in figure 2 ultimately result in a state of maturity that can be represented as in figure $3 A$. This straight-line graphic approach necessitates that the rate of redeposition at maturity (fig. $3 A$ ), however, remain constant from the redox interface nearly to the tail of the deposit. Such constant rate throughout the deposit, though chemically possible, is obviously improbable, because it implies some significant change in the type, or order, of geochemical reaction between inception (fig. 2) and maturity (fig. $3 A$ ). Neither does the distribution indicated in figure $3 A$ faithfully mimic the pattern of pyrite concentrations actually observed in the deposits. In natural occurrences, the graphed shape of the pyrite concentrations plotted across roll-type deposits is invariably uneven, but such a curve, when smoothed, tends to look much like figure $3 B$. This configuration suggests an exponential or inversely proportional decrease in deposition across the deposits. Nearly all chemical precipitations occur by either first-order or second-order processes and would be expected to produce just such a distribution from: a dynamic system as proposed for roll-type ore genesis.

If we imagine each ore-stage sulfur increment as having a curved upper surface in figure 2 , the generation of figure $3 B$ at maturity is easily visualized. We chose, as first approximations, the representations shown in figures 2 and $3 A$ because they can-be more readily manipulated geometrically.

The approach to maturity is asymptotic, but for all practical purposes maturity is reached when the redox interface has traveled a relatively short distance. If the process involved has an efficiency of 50 percent, virtual (say, 95 percent) maturity is reached in a distance of three cycles; if it has an 80-percent efficiency, maturity is approximately completed only after the front travels nearly eight cycles. This is illustrated in figure 4, which shows curves generated by the maximum ore-stage pyrite contents during growth to maturity; each curve represents a different efficiency. The greater the efficiency, the

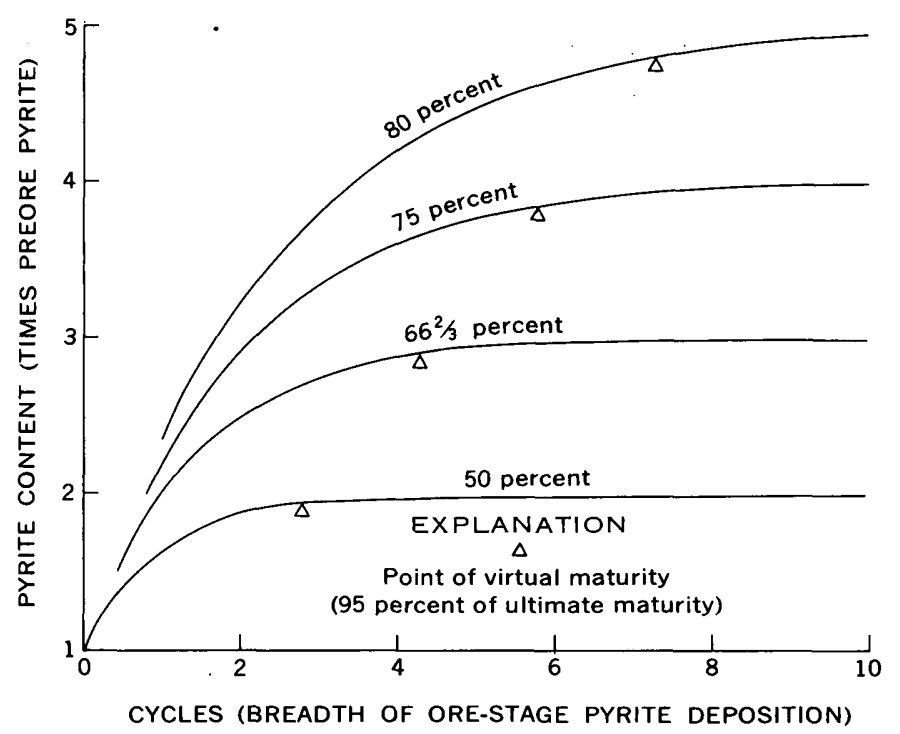

Figure 4.-Growth curves for maximum pyrite content at various efficiencies of redeposition of ore-stage pyrite.

longer the time required for the process to attain maturity. The natural distribution of preore pyrite is never perfectly uniform (fig. 5). Redistribution during the roll-forming process tends to compensate for these variations, however. Any given concentration of pyrite in a deposit must be maintained by a complementary amount of preore pyrite; the effects of local, unusually high or unusually low concentrations of preore pyrite are lost within a few cycles as the redox interface advances, and the amount of ore-stage pyrite is governed by the average preore pyrite content. Highly efficient processes take longer than less efficient processes do to adjust completely to a local fluctuation in the preore pyrite content (fig. 4). On the other hand, the highly efficient process results in the more regular distribution of ore-stage pyrite because it averages the effects of fluctuations in the preore pyrite content over a longer distance. Broad-scale fluctuations in the preore pyrite content, of course, result in correspondingly broad-scale fluctuations in the amount and distributions of ore-stage pyrite.

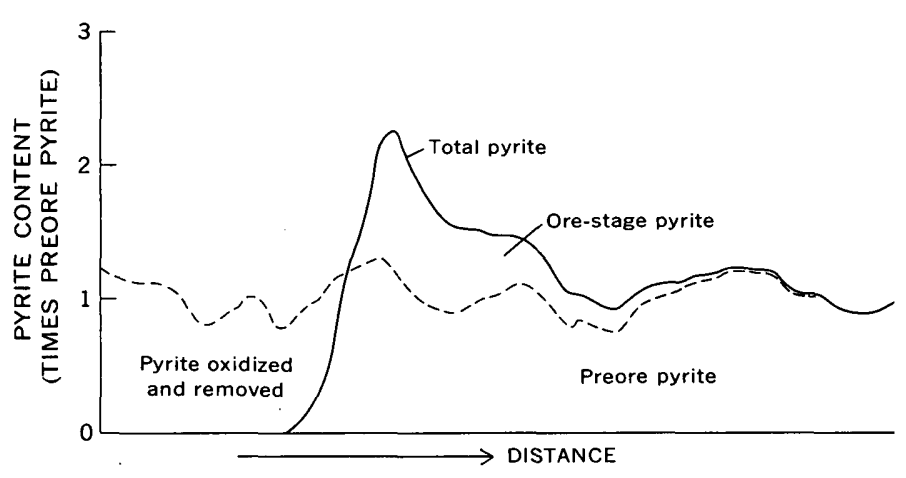

Figure 5.-Typical pyrite distribution in a roll-type deposit showing irregularities that can result from uneven distribution of preore pyrite. 
The maximum concentrations of pyrite in the rolls are generally, but not always, just in advance of the redox interface. Presumably, the pyrite content that might be expectable at a given place in a deposit can vary owing to previously existing, greater-than-normal accumulations of preore pyrite or to some unspecified factor which enhanced ore-stage pyrite deposition at that point. Such expectable irregularities do not constitute a valid objection to the steady-state concept.

Ideally, the efficiency of the redepositional process is a parameter of the particular system involved. If, for example, the system entails oxidation of pyrite sulfur to an active sulfur species which then disproportionates (Granger and Warren, 1969) in such a way that exactly half the sulfur is reconverted to a sulfide, the total pyrite at the redox interface in a mature deposit should, ideally, be twice the preore pyrite content. Other chemical processes of disproportionation could produce equally distinctive earmarks of the exact process involved. Whether or not such definite limitations can be placed on natural systems by use of less precise field and analy tical data is not yet known.

If the concept of maturity and steady state is valid with regard to the amount and distribution of total ore-stage sulfide sulfur, then the concept should also be applicable to each isotope of sulfur. The results of applying the concept should be no more susceptible to local variations in isotopic composition of the preore pyrite than to the quantity of pyrite. Patterns of isotope distribution should grow, mature, and then continue as part of a steady-state process much as the total sulfide content changes, but perhaps at a different initial rate of growth. This idea, more thoroughly explored by Warren (1972), is mentioned here because regularities of sulfur isotope distribution known to occur in some roll-type deposits (King and Austin, 1966; Austin, 1970) are compatible with a steady-state process.

\section{SUMMARY}

In summary, the accumulation of ore-stage pyrite in a roll-type deposit is largely, or entirely, a process of continuous redistribution. The process starts by dissolution of pyrite that is already present in the rock and reprecipitation of a part of it in advance of the point of dissolution, or at redox interface. The ratio of the amount reprecipitated to the amount dissolved can be called the efficiency of the reaction and is a positive function of the maximum pyrite accumulations. The reprecipitated pyrite steadily accumulates until the amount lost in each cycle is equal to the amount initially present in the rock. At this time the deposit has reached maturity and the accumulated pyrite moves along in advance of the redox interface as a continuous wave, neither significantly increasing nor decreasing in size so long as the other parameters remain unchanged. The principal reason that large, rich accumulations of ore-stage pyrite are rarely, if ever, seen in these deposits seems to be that only an extremely efficient process would permit more than a few-fold compounding of the original preore pyrite content.

\section{REFERENCES CITED}

Armstrong, F. C., 1970, Geologic factors controlling uranium resources in the Gas Hills district, Wyoming: Wyoming Geol. Assoc. Guidebook, 22d Ann. Field Conf., p. 31-44.

Austin, S. R., 1970, Some patterns of sulfur isotope distribution in uranium deposits: Wyoming Geol. Assoc. Earth Sci. Bull., p. 5-22.

Bailey, R. V., 1969, Uranium deposits in the Great Divide BasinCrooks Gap Area, Fremont and Sweetwater Counties, Wyoming, in Wyoming Uranium Issue, Contribution to Geology, Univ. of Wyoming, v. 8 , no. 2 , pt. 1, p. 105-120.

Davis, J. F., 1969, Uranium deposits of the Powder River Basin, in Wyoming Uranium Issue, Contributions to Geology, Univ. of Wyoming, v. 8, no. 2, pt. 1, p. 131-141.

Eargle, D. H., and Weeks, A. M. D., 1968, Factors in the formation of uranium deposits, Coastal Plain of Texas: South Texas Geol. Soc. Bull., v. 9, no. 3, p. 1-11.

Germanov, A. N., 1960, Main:genetic features of some infiltration-type hydrothermal uranium deposits: Akad. Nauk SSSR Izv. Ser. Geol., no. 8, p. 60-71. [English translation]

Granger, H. C., and Warren C. G., 1969, Unstable sulfur compounds and the origin of roll-type uranium deposits: Econ. Geology, v. 64, no. 2 , p. $160-171$.

Harshman, E. N., 1962, Alteration as a guide to uranium ore, Shirley Basin, Wyoming: Art. 122 in U.S. Geol. Survey Prof. Paper 450-D, p. D8-D10.

_ 1966, Genetic implications of some elements associated with uranium deposits, Shirley Basin, Wyoming, in Geological Survey Research 1966: U.S. Geol. Survey Prof. Paper 550-C, p. C167-C173.

1970, Uranium ore rolls in the United States: Uranium Exploration Geology, Internat: Atomic Energy Agency, Vienna, Austria, p: 219-232.

Kashirtseva, M. F., 1964, Mineral and geochemical zonation of infiltration uranium ores: Soviet Geology, no. 10, p. 5]-65. [English translation ]

Kholodov, V. N., Lisitsyn, A. K., Komarova, G. V., and Kondrat'yeva, I. A., 1961, Epigene zoning of uranium mineralization in petroliferous carbonate rocks: Akad. Nauk SSSR Izv., Ser. Geol., no. 11, p. 43-56.

King, J. W., and Austin, S. R., 1966, Some characteristics of roll-type uranium deposits at Gas Hills, Wyoming: Mining Eng., v. 18, no. 5, p. $73-80$.

Lisitsyn, 'A. K., and Kuznetsova, E. C., 1967, Role of microorganisms in development of geochemical reduction barriers where limonitization bedded zones wedge-out: Akad. Nauk SSSR Izv. Ser. Geol., no. 1, p. 31-44. [English translation, Internat. Geology Rev., v. 9, no. 9, p. 1180-1191, 1967]

Melin, R. E., 1964, Description and origin of uranium deposits in Shirley Basin, Wyoming: Econ. Geology, v. 59, no. 5, p. 835-849. 1969, Uranium deposits in Shirley Basin, Wyoming, in Wyoming Uranium Issue: Wyoming Univ. Contr. Geology, v. 8, no. 2, pt. 1, p. 1.3.3-149.

Shawe, D. R., and Granger, H. C., 1.965, Uranium ore rolls-An analysis: Econ. Geology, v. 60, no. 2, p. 240-250.

Warren, C. G., 1971, A method for discriminating between biogenic and chemical origins of the ore-stage pyrite in a roll-type uranium deposit: Econ. Geology, v. 66, no. 6, p. 919-928.

1972, The use of sulfur isotopes as a clue to the genetic geochemistry of a roll-type uranium deposit: Econ. Geology, v. 67, no. 6, p. $759-767$. 


\title{
AGE AND TECTONIC IMPLICATIONS OF SOME LOW-GRADE METAMORPHIC ROCKS FROM THE YUCATAN CHANNEL
}

\author{
By J. G. VEDDER, N. S. MacLEOD, M. A. LANPHERE; and \\ W. P. DILLON, Menlo Park, Calif.; Woods Hole, Mass.
}

\begin{abstract}
Phyllite and marble dredged from the lower part of the continental slope between Cuba and the Yucatan Peninsula seem to support the contention that a pre-early Tertiary metamorphic belt extends from the western Greater Antilles into northern Central America. The minimum K-Ar ages derived from the samples suggest that the metamorphic event was pre-Late Cretaceous, and evaluation of the K-Ar data implies that this metamorphic event is not older than Late Jurassic. Greater antiquity, however, is inferred from structural and stratigraphic relations in British Honduras, where the latest regional metamorphic event was post-Early Permian and pre-Middle Jurassic. Rifting and extension related to plate motions along the British Honduras-Quintana Roo margin through Mesozoic and earliest Cenozoic time presumably would preclude extensive regional metamorphism, permitting only limited development of schistose rocks there during that interval. The timing of metamorphic events in western Cuba is uncertain, but a pre-Middle Jurassic episode possibly is reflected in the phyllite and marble terranes of Isla de Piños and Sierra de Trinidad. Local incipient metamorphism of Early and Middle Jurassic strata in the Sierra de los Órganos may have resulted from severe tectonism that began in Late Cretaceous time and diminished in the Eocene.
\end{abstract}

During the U.S. Geological Survey-International Decade of Ocean Exploration (USGS-IDOE) Leg 2 study of the east continental margin of the Yucatan Peninsula in June and July 1.971., dredge samples were taken to determine the age and composition of sea floor outcrops in the region where geophysical data were being acquired (Vedder and others, 1.971.). Two dredge hauls (fig. 1), one $94 \mathrm{~km}$ southwest of Cabo San Antonio, Cuba, the other $85 \mathrm{~km}$ southeast of Punta Molas, Isla de Cozumel, Mexico, yielded abundant low-grade metamorphic rocks from near the base of the continental slope. These rocks are critical to the interpretation of the structural evolution of the Yucatan Channel and the continental margin southwest of it. Unfortunately, precise stratigraphic correlation and radiometric age of the dredged samples cannot be resolved at present, and the relationship of these rocks to similar metamorphic terranes in northern Central America and Cuba is conjectural.

\section{GEOLOGIC SETTING}

Yucatan region

The Yucatan Peninsula is underlain by crystalline basement rocks that are Paleozoic in age in central Guatemala and southern British Honduras (Kesler, 1971), perhaps older in adjacent areas. This basement is overlain by late Paleozoic clastic sedimentary rocks that are partly metamorphosed and by unmetamorphosed Mesozoic and Cenozoic rocks composed mainly of carbonates. Several episodes of igneous intrusion and tectonism have deformed these strata, and two folding events, one Paleozoic and the other Mesozoic, have been recognized throughout northern Central America (Dengo, 1969). In the northern part of the peninsula, pre-MiddleJurassic felsic metaporphyry was penetrated in Yucatan 1 well beneath more than $3,000 \mathrm{~m}$ of Cretaceous and Tertiary anhydrite and limestone and about $400 \mathrm{~m}$ of Jurassic red beds (Bass and Zartman, 1.969; Viniegra, 1971). Similar rocks were drilled in Yucatan 2 well beneath a slightly thinner sedimentary sequence. Andesite of probable pre-Cretaceous age underlies Turonian(?) and younger carbonates and evaporites in wells near Mérida (Mina, 1966; Bryant and others, 1969).

In the Maya Mountains of British Honduras, the oldest exposed sedimentary rocks are marine shale, sandstone, and limestone of late Paleozoic age that are locally metamorphosed (Dixon, 1956). These deformed clastic rocks are locally interlayered with felsic volcanic porphyry and are cut by granitic intrusive bodies that are assigned an age range of Pennsylvanian to Triassic (Bateson and Hall, 1971; Hall and Bateson, 1972; Bateson, 1972). The absence of latest Paleozoic and early Mesozoic strata suggests that the region was positive during that time interval.

Another cycle of sedimentation began throughout northern Central America during Late Jurassic to Early Cretaceous time with limited deposition of thin, discontinuous successions of Jurassic red beds followed by thicker sequences of Cretaceous shallow-water marine sediments. Widespread deposition of shallow-water carbonates, evaporites, and clastic strata continued in broader, deeper basins in Late Cretaceous and early 


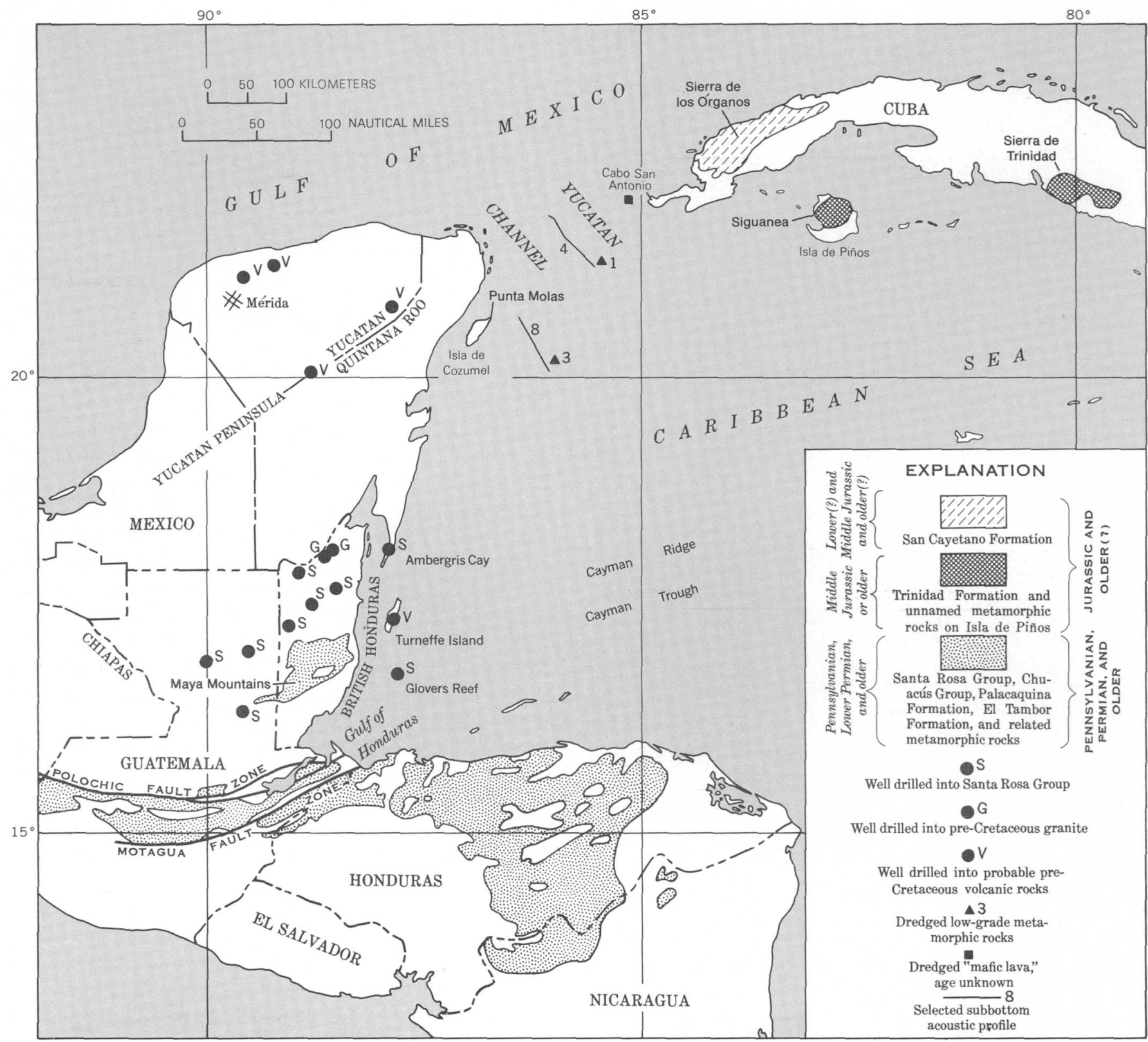

Figure 1.-Generalized map showing the distribution of low-grade metamorphic rocks, related sedimentary rocks, and drilled igneous rocks in northern Central America and western Cuba. Modified from Dengo (1969) and Khudoley and Meyerhoff (1971).

Tertiary time, during which plutonic intrusions locally were emplaced in the southeastern part of Guatemala (Williams and McBirney, 1969; Clemons and Long, 1971). Relatively thin, slightly deformed carbonate platform deposits constitute the bulk of the Tertiary strata on the northeastern part of the Yucatan Peninsula, where all the series except Oligocene are represented in the stratigraphic succession (Flores, 1952).

Northeast-trending normal faults cut the Tertiary section in northwestern British Honduras and Quintana Roo (Alvarez, 1954), and a similar set of faults along the continental margin is postulated by Dengo and Bohnenberger (1969) and Dillon and Vedder (1972). A possibly older set of faults, on which there may have been recurrent movement, displaces the Paleozoic and Mesozoic sequences of the Maya Mountains. These faults trend eastward in the western part of the mountains, but some curve northeast as they approach the coast (Dixon, 1956). A major east-trending zone of faults (Motagua-Polochic system) in central Guatemala apparently extends eastward into the Cayman Ridge and Trough. This fault zone seems to separate widespread phyllite and schist of the greenschist facies on the south from mildly metamorphosed and unmetamorphosed strata in the Maya Moun- 
tains (Dengo, 1969). The belt of rocks between the bounding faults of the zone consists in large part of pre-Pennsylvanian schist and gneiss (Kesler, 1971) and contains elongate bodies of serpentinite that probably were intruded in Late Cretaceous time.

\section{Western Cuba}

The age of the so-called basement complex of western Cuba is unknown. Metamorphosed sedimentary rocks exposed on Isla de Piños are unconformably overlain by marine pyroclastics of Albian to Cenomanian age (Kuman and Gavilán; 1965); somewhat similar pre-Upper Cretaceous metamorphic rocks underlie much of the Sierra de Trinidad (Hill, 1959). Hatten (1967) believes that both sequences are Paleozoic, but Khudoley (1.967) and Kuman and Gavilán (1965) correlate them with the Jurassic San Cayetano Formation and Viñales Limestone of the Sierra de los Organos. The San Cayetano is composed of a thick, repetitious succession of beds of marine and nonmarine quartzose sandstone, siltstone, and shale that are locally mildly metamorphosed and that contain a Bathonian and Callovian marine fauna in the upper part (Hatten, 1967; Meyerhoff and others, 1969; Hatten and Meyerhoff., 1.970). Volcanic detritus is absent. The formation is intruded by serpentinite, primarily along faults; and it may be partly equivalent in age to the evaporite deposits in the Punta Alegre Formation on the Cuban north coast (Meyerhoff and Hatten, 1968). The San Cayetano is overlain by a Late Jurassic clastic and carbonate sequence, which in turn is overlain by a succession of pelagic carbonate units of Cretaceous age (Khudoley and Meyerhoff, 1971).

From Albian through Turonian time, gentle folding interrupted normal deposition, volcanic activity ceased in the west-central part of the island, and dioritic rocks probably began to be emplaced in central and eastern Cuba near the end of this time interval. At the end of Cretaceous time, orogenic activity intensified and during the earliest Tertiary culminated with the formation of nappe structures and the intrusion of granitic plutons (Meyerhoff and others, 1969; Meyerhoff in Khudoley and Meyerhoff, 1971). By the end of Eocene time, large-scale faulting and folding had diminished in western Cuba; younger Tertiary rocks are only slightly deformed.

\section{Continental margin east of Yucatan Peninsula}

Little is known about the geology of the sea floor in the segment of continental margin that extends southwestward from Cabo San Antonio, Cuba, into the Gulf of Honduras. Subbottom reflection profiles show that narrow, sedimentdamming ridges extend southward from the Yucatan Channel to British Honduras to form a pattern of linear structures that are alined approximately parallel to the edge of the continent (Baie, 1970; Vedder and others, 1971; Dillon and Vedder, 1972). Parts of two subbottom acoustic profiles (fig. 2) illustrate one of these well-defined ridges of acoustic base- ment. Large northeast-trending faults are assumed to bound individual blocks but are not discernible on the original profiles. The slightly deformed reflectors in the basins that lie shoreward of the ridge are inferred to be in a carbonatedominated sedimentary sequence that includes strata of both Cretaceous and Tertiary age similar to that in basins offshore from British Honduras (Dillon and Vedder, 1.972). The age range of the thin wedges of sediment that flank the seaward side of the ridge in both profiles is not certain, but foraminifers dredged from this slope indicate that some of it is mid-Tertiary. Quaternary deposits, chiefly pelagic, presumably mantle most of the older rocks.

\section{DREDGED METAMORPHIC ROCKS}

\section{Station 1}

Numerous angular pieces of rock, primarily phyllite and marble, were dredged at station 1 (lat $21^{\circ} 13.2^{\prime} \mathrm{N}$.; long $83^{\circ} 31.0^{\prime} \mathrm{W}$.). They average about $5 \mathrm{~cm}$ in maximum dimension; the largest fragment is about $25 \mathrm{~cm}$ long. Many have fresh surfaces as though broken from outcrops, although some are weathered and partly manganese coated. The haul was made up the steep part of the slope (fig. 2, profile 4) in a depth range of 2,715-2,490 m. A large amount of Pleistocene(?) and Holocene pteropod-globigerine ooze in the dredged sample may be from the thin wedge of bedded sediment over the acoustic basement on the slope about $2-3$ $\mathrm{km}$ south of the dredge site shown on profile 4 (fig. 2). The steep slopes and peaks of acoustic basement are assumed to be underlain chiefly by metamorphic rocks similar to those recovered in the haul, although intrusive igneous rocks and serpentinite bodies probably are present in adjacent areas.

The largest pieces of rock from station 1 are angular fragments of marble that typically are streaked with irregular dark and light bands. The dark bands consist of laminated dark-gray fine-grained impure limestone that are as much as 1 $\mathrm{cm}$ thick; the laminae are parallel in some fragments but are tightly folded in others. The light bands are veins of white coarsely crystalline limestone that disrupt both the dark layers and the folds. Thin lenses and laminae of phyllite, 1.-8 mm thick, are interlayered with the dark-gray limestone.

Three typical phyllite fragments from station 1 were studied in thin section. These rocks represent the greenschist facies (quartz-albite-muscovite-chlorite or quartz-albite-biotitemuscovite assemblage) and presumably were derived from mudstone or siltstone and silty limestone. The first consists of quartz, albite, chlorite, muscovite, and biotite, with accessory calcite, sphene, zircon, hydrous iron oxides, and opaque minerals. It has well-developed bands of quartzo-feldspathic and micaceous layers that are shear folded into tight, almost isoclinal, microfolds with sheared limbs. The amplitude of the larger folds averages about $1 \mathrm{~cm}$, but fold limbs and crests are highly crenulated. Most quartz and albite grains are less than $0.05 \mathrm{~mm}$ in diameter. They recrystallized after deformation, as 


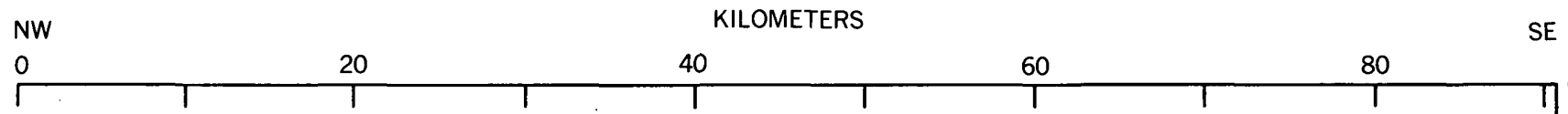

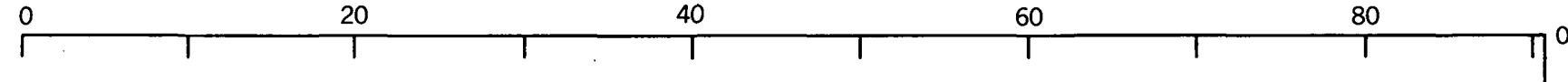

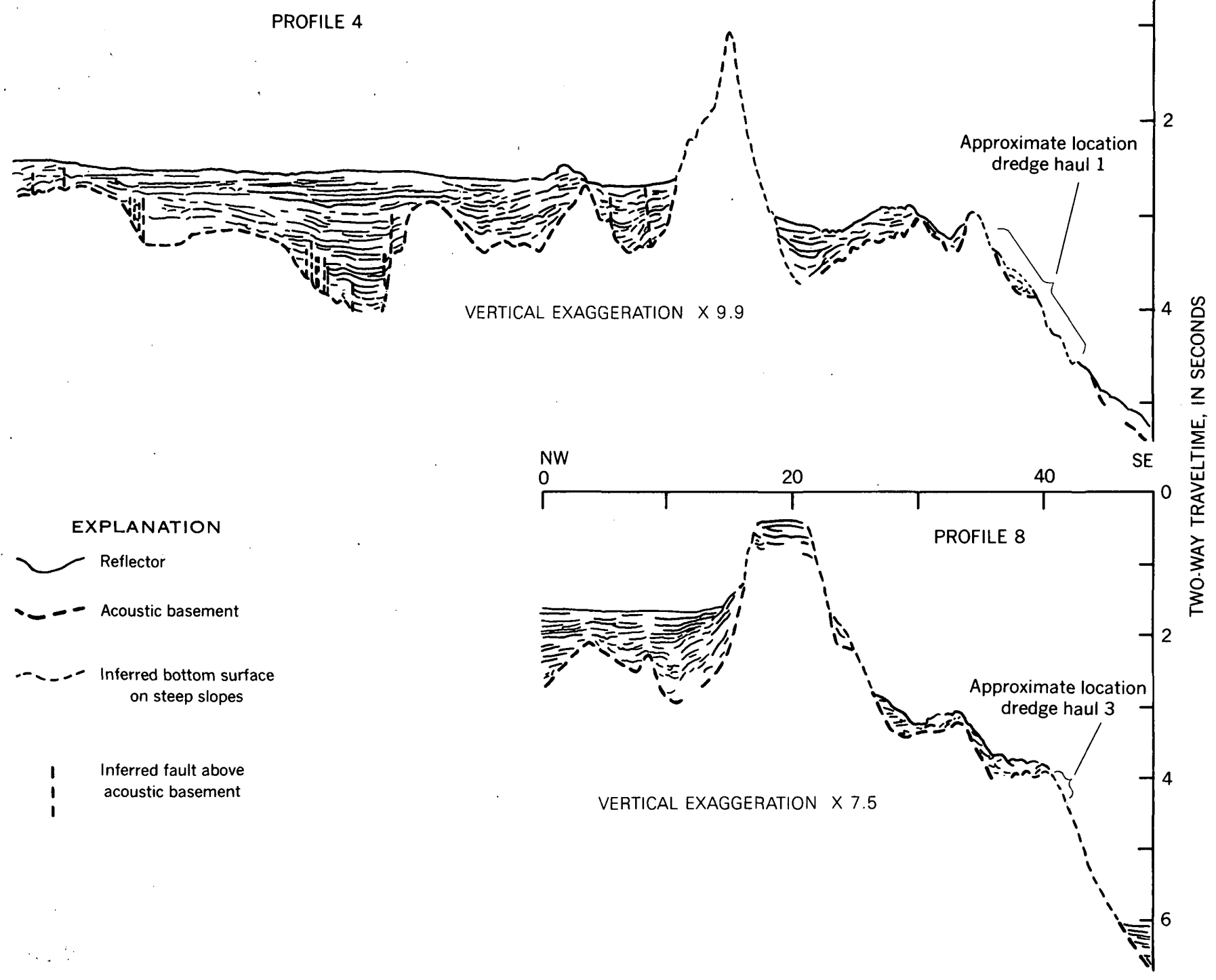

Figure 2.-Interpreted subbottom acoustic profiles showing the relation of dredge hauls to exposures of acoustic basement and to position on the continental slope. The profiles and dredge stations are numbered to agree with those of the original survey (Vedder and others, 1972).

shown by their mosaic texture and lack of strain or preferred orientation. A few larger quartz ovoids as much as $0.3 \mathrm{~mm}$ long are highly strained but are recrystallized at their margins to a granoblastic mosaic of unstrained quartz. Rhombs of calcite and plates of muscovite, chlorite, and biotite are scattered through the quartzo-feldspathic layers. The micaceous layers interleaved between the quartzo-feldspathic layers are typically $0.1 \mathrm{~mm}$ thick and are composed of chlorite, muscovite, and biotite, with lesser quartz and albite.

The second sample of phyllitic rock consists of muscovite, quartz, albite, and chlorite with accessory calcite, sphene, rutile, and apatite. It has a very well developed foliation and poorly developed crenulation lineation. The surfaces of fragments have a pronounced sheen produced by minute mica flakes. Small (1 by $5 \mathrm{~mm})$ to microscopic $(0.1 \mathrm{~mm})$ ovoid porphyroblasts of albite and quartz and discontinuous quartzo-feldspathic layers constitute a small proportion of the rock.

The third sample is a phyllitic marble that consists of calcite, quartz, muscovite, and chlorite, with accessory sphene and epidote. Unlike the other phyllite samples, it contains no detectable albite. Calcite makes up 80-90 percent of the sample and occurs as lenses of minute grains that have a mosaic texture and layers of interleaved elongate grains 
$0.1-0.3 \mathrm{~mm}$ wide and as much as $0.5 \mathrm{~mm}$ long. Slightly strained quartz grains are generally scattered throughout the calcite but show greater concentrations along some foliation planes, where they occur with muscovite and chlorite in addition to calcite.

A single small piece of highly sheared serpentinite was collected from dredge station 1 and was identified by petrographic and X-ray methods. Its occurrence is supporting evidence for a southwestward continuation of the Cuban ultramafic belt, which in turn may be related to similar intrusive zones that were most active during latest Cretaceous and earliest Tertiary time in the circum-Caribbean region (Dengo, 1969; MacGillavry, 1970). Small, perhaps older, serpentinite bodies occur in a northwest-trending zone through the north-central part of Isla de Piños (Kuman and Gavilán, 1.965; Khudoley and Meyerhoff, 1971), where they intrude phyllite and schist that may correlate with the metamorphic rocks from both dredge stations. Mafic lava(?) of unknown age reported from a Russian dredge haul about $20 \mathrm{~km}$ west of Cabo San Antonio (Khudoley and Meyerhoff, 1971) possibly is related to Cretaceous diabasic rocks that are exposed in western Cuba (unit $\mathrm{vCr}_{2}$, Khudoley and others, 1963).

\section{Station 3}

The haul from station 3 (lat $20^{\circ} 10.5^{\prime} \mathrm{N}$.; long $86^{\circ} 03.6 \mathrm{~W}$.) consists of numerous angular fragments of phyllite and a few small pieces of schist pebble conglomerate that were dredged in the depth range of $3,090-2,920 \mathrm{~m}$. The phyllite fragments range in length from a few millimeters to $21 \mathrm{~cm}$. Most have weathered surfaces coated with manganese oxide and seem to be from submarine scree derived from the top of the steep lower slope (fig. 2, profile 8); a few large fragments with freshly broken surfaces may have been torn from outcrops during dredging. Pleistocene and Holocene pteropod-globigerine ooze constitutes the remainder of the haul and is assumed to represent a thin cover of sediment on the metamorphic rocks. The pebble-conglomerate fragments may be slumped material from thicker sediment accumulations that lie between the steep lower slope and the high basement ridge, but the precise relations are uncertain, as the dredge site is $1-2 \mathrm{~km}$ north of the profile. The matrix of the conglomerate contains Lepidocyclina sp. and other smaller foraminifers that suggest deposition during late Eocene to early Miocene time, possibly Oligocene, and a water depth much shallower than that at the site today if the fossils are not displaced. Reflectors atop the high-standing basement ridge may indicate the presence of ancient coral reefs that were drowned by subsidence of the continental margin (Vedder and others, 1971.).

The quartz-albite-muscovite-chlorite assemblage in the phyllite samples from station 3 indicates that the rocks represent the greenschist facies. The phyllite probably was derived from siltstone or silty sandstone, and the abundant calcite in one sample suggests that some of the original sediment may have been rich in carbonate.
All phyllite samples examined from station 3 have a well-developed foliation, and a few also have a weakly developed lineation produced by intersection of the principal foliation with a later shear foliation that is oriented $30^{\circ}-60^{\circ}$ oblique to the principal foliation. The foliation surfaces have a silky sheen imparted by parallel muscovite plates that are barely visible to the unaided eye. Most samples show segregation layering with quartzo-feldspathic layers $1-5 \mathrm{~mm}$ thick between the micaceous layers.

Two samples studied in thin section consist of quartz, albite, muscovite, and chlorite; a third contains the same minerals plus abundant calcite. Accessory and secondary minerals include apatite, biotite, sphene, rutile, zircon, opaque minerals, and hydrous iron oxide. Quartzo-feldspathic bands make up about half of each sample, although in the calcite-bearing phyllite the segregation into quartzo-feldspathic and micaceous bands is poorly defined. Some quartzo-feldspathic layers are devoid of muscovite and chlorite; others contain abundant chlorite. Quartz and albite in these layers are highly strained, and the quartz shows a preferred orientation. Grain size is mostly less than $0.2 \mathrm{~mm}$, but some irregular albite crystals and strained quartz ovoids are as large as 1 by $2 \mathrm{~mm}$. Larger quartz grains contain small fluid inclusions. The chlorite occurs as parallel crystals scattered with quartz and albite through the micaceous layers, whereas the muscovite is principally confined to $0.1-0.2-\mathrm{mm}$-thick bands consisting almost entirely of interleaved muscovite crystals. Some muscovite and chlorite is alined along secondary shear surfaces. Biotite occurs in minute amounts interleaved with chlorite. Disrupted albite grains and strongly undulatory quartz ovoids with irregular boundaries indicate additional shearing during or after crystallization.

\section{POTASSIUM-ARGON AGE MEASUREMENTS}

It was not possible to separate pure muscovite or biotite from the dredged samples, for these minerals are too fine grained and intricately intergrown with chlorite. The concentrate of sheet-structure minerals from station 1. was split into three fractions by use of magnetic techniques; the least magnetic fraction, "muscovite," and most magnetic fraction, "chlorite," were analyzed. Inasmuch as the quantity of material in the sheet-structure mineral concentrate from station 3 was too small to split into separate fractions, the total chlorite-muscovite-biotite mixture, "biotite," was analyzed. X-ray diffraction patterns and the relatively low $\mathrm{K}_{2} \mathrm{O}$ content indicate that chlorite is equal to or more abundant than mica in all three analyzed samples.

Argon measurements by isotope-dilution methods were made using equipment and techniques previously described (Dalrymple and Lanphere, 1969). Potassium content was measured by flame photometry using a lithium internal standard. The plus-or-minus value assigned to each age measurement (table 1) is an estimate of the standard deviation of analytical precision, using the method of Cox and Dalrymple (1967), together with an estimate of accuracy 
Table 1.-Analytical data and potassium-argon ages for samples dredged from stations 1 and 2

[Constants used: $\mathrm{K}^{40} \lambda \epsilon=0.585 \times 10^{-10} \mathrm{yr}^{-1} ; \mathrm{K}^{40} \lambda \beta=4.72 \times 10^{-10} \mathrm{yr}^{-1}$. Abundance: $\mathrm{K}^{40}=1.19 \times 10^{-4}$ atom percent. Analysts: $\mathrm{L}$. B. Schlocker, potassium measurements; J. C. Von Essen, argon measurements and age calculations]

\begin{tabular}{|c|c|c|c|c|c|}
\hline $\begin{array}{l}\text { Sample } \\
\text { No. }\end{array}$ & Mineral & $\begin{array}{c}\mathrm{K}_{2} \mathrm{O} \text { content }{ }^{1} \\
\text { (percent) }\end{array}$ & $\begin{array}{c}\text { Radiogenic } \\
\text { argon } \\
\left(10^{-10} \text { moles } / g\right)\end{array}$ & $\frac{\mathrm{Ar}^{40} \text { radiogenic }}{\mathrm{Ar}^{40} \text { total }}$ & $\begin{array}{c}\text { Calculated } \\
\text { age } \\
\text { (m.y.) }\end{array}$ \\
\hline 1. . & "Muscovite" & $4.73,4.75(4.74)$ & 6.638 & 0.81 & $92.5 \pm 2.8$ \\
\hline $2 \ldots$ & "Chlorite" & $2.77,2.78(2.78)$ & 3.074 & .63 & $73.5 \pm 2.3$ \\
\hline $3 \ldots$ & "Biotite" & $1.373,1.377(1.375)$ & 1.223 & .54 & $59.3 \pm 2.0$ \\
\hline
\end{tabular}

${ }^{1}$ Percentage values in parentheses are averages.

based on evaluation of the uncertainties in the isotope composition and concentration of the $\mathrm{Ar}^{38}$ tracer and concentrations of the flame photometer standards.

The three potassium-argon ages (table 1) are not in agreement, and the two fractions from station 1 differ by much more than the uncertainty of the individual measurements. The age of $92.5 \mathrm{~m}$.y. for the "muscovite" fraction from station 1 is interpreted as a minimum age for the development of the mineral assemblage.

A maximum age for the time of metamorphic recrystallization can be inferred from a plot of the results for station 1 on an age-versus- $\mathrm{K}_{2} \mathrm{O}$ diagram in which it is assumed that the two fractions define a mixing line that can be extrapolated to a "pure" muscovite end member and that all the chlorite is derived from muscovite. This construction results in inferred ages of $134 \mathrm{~m} . \mathrm{y}$. and $154 \mathrm{~m} . \mathrm{y}$. for $\mathrm{K}_{2} \mathrm{O}$ contents of 9 and 11 percent, respectively. As it is unlikely that the "pure" muscovite contains more than 11 percent $\mathrm{K}_{2} \mathrm{O}$, an inferred maximum age of metamorphism is about $155 \mathrm{~m}$.y. This age is Late Jurassic on most compilations of the geologic time scale, but the inferred maximum age of metamorphism could be as young as Early Cretaceous, depending on the $\mathrm{K}_{2} \mathrm{O}$ content of the "pure" muscovite. The age of $59.3 \mathrm{~m} . \mathrm{y}$. for the sample from station 3 is a minimum value for the metamorphic event in which the mineral assemblage was produced.

In summary, the potassium-argon results indicate minimum ages of 92.5 and $59.3 \mathrm{~m} . \mathrm{y}$. for the metamorphism of the phyllites at stations 1 and 3 , respectively. Evidence for possible systematic loss of $\mathrm{Ar}^{40}$ suggests that these phyllites were more likely produced by older metamorphism, perhaps during mid-Mesozoic time.

\section{REGIONAL DISTRIBUTION OF LOW-GRADE METAMORPHIC ROCKS}

Low-grade metamorphic rocks, chiefly phyllite and schist, are common in pre-Cretaceous terranes throughout the western Greater Antilles and northern Central America (fig. 1) (Dengo, 1969; Meyerhoff and others, 1969; Khudoley, 1967; Williams and McBirney, 1969; McBirney and Bass, 1969; Khudoley and Meyerhoff, 1971). In the Maya Mountains of southern British Honduras, a thick sequence of locally metamorphosed sedimentary rocks has been assigned a Pennsylvanian to Late Permian age. Dixon (1956) called the metamorphosed part of the sequence the Maya Series and separated it from shales and sandstones that he assigned to the Macal Series. Dengo (1969) provisionally accepted this interpretation and correlated the metamorphic rocks with the Chuacús Group (McBirney, 1963) in Guatemala and Chiapas, Mexico. Later detailed work by Kesler and others (1971), Bateson and Hall (1971), and Bateson (1972) has demonstrated that the Maya and Macal Series are coeval in part and that they correlate with the Santa Rosa Group of Pennsylvanian and Permian age in Guatemala (Bohnenberger, 1966). Precise correlation with the metamorphic rocks of the Palacaguina Formation in southern Guatemala and Honduras, south of the Motagua-Polochic fault system, is uncertain (Dengo, 1969).

Muscovite phyllite that presumably is equivalent to that exposed in the Maya Mountains was penetrated below about $2,218 \mathrm{~m}$ in the Gulf-Shell Basil Jones 1 well on Ambergris Cay about $111 \mathrm{~km}$ northeast of the northeasternmost outcrops in British Honduras (fig. 1). The Shell Oil Co. Glover well at the south end of Glovers Reef also penetrated rocks that may correlate with the Santa Rosa Group. Here $182 \mathrm{~m}$ of shale and phyllite was drilled below Eocene and Upper Cretaceous strata in the depth interval 777-959 m. On Turneffe Island, the Shell Oil Co. Turneffe well did not recover phyllite but drilled into pre-Upper Cretaceous extrusive andesitic(?) volcanic rocks at $1,692 \mathrm{~m}$ that may be related to the rhyolitic Bladen Volcanic Member of the Santa Rosa Group (Bateson and Hall, 1971; Hall and Bateson, 1972) but are more likely to represent younger intermediate to mafic rocks in the Antillean geosynclinal belt.

Muscovite phyllite and schist with intercalated limestone and marble from Isla de Piños, Cuba, have been described by Rutten (1934), Page and McAllister (1944), Kuman and Gavilán (1965), and Tijomirov (1967). J. E. McAllister (oral commun., 1971) briefly examined a few hand specimens from the dredge hauls and remarked that they closely resemble rocks from the Siguanea district. Kuman and Gavilán correlate the unfossiliferous succession on the island with the San Cayetano Formation and Vinales Limestone of Jurassic age in western Cuba; Hatten (1967) disagrees with this comparison 
and assigns it to the Paleozoic. Similar low-grade metamorphic rocks are exposed in the Sierra de Trinidad in central Cuba and perhaps in eastern Oriente Province in the Sierra Maestra in southeastern Cuba (Palmer, 1945; Hill, 1959; Khudoley, 1967; Skvor, 1.969; Khudoley and Meyerhoff, 1971).

The abundance of phyllite and marble fragments dredged from near the base of the slope suggests that the basement ridges are composed primarily of low-grade metamorphic rocks, although intrusive igneous rocks and serpentinite bodies are presumed to be present. The wide distribution of similar metamorphic rocks both in western Cuba and northern Central America indicates that a broad, fragmented belt of low-grade metamorphic rocks may underlie the margin of the northwestern Caribbean. It is unlikely that these mildly metamorphosed sedimentary terranes developed from rocks of the same age, and the evidence for suggesting that the metamorphic event was everywhere the same age is lacking.

\section{SUMMARY AND CONCLUSIONS}

In northern Central America, two major episodes of tectonism that could have produced regional metamorphism followed the deposition of the late Paleozoic Santa Rosa Group. The first event included wide-ranging deformation by north-south compression, intrusion by granitic plutons, and uplift of large segments of "nuclear Central America" sometime during the interval between Early Permian and Middle or Late Triassic time. This event was followed by extensional tectonics that formed the ancestral Gulf of Honduras in Late Jurassic through Early Cretaceous time. A second significant orogenic event developed through Late Cretaceous and earliest Tertiary time and seems to have affected the entire western Caribbean. Concurrently, the rocks of the Sierras of northern Central America were intensely folded and thrust northward, strike-slip movement may have begun along the MotaguaPolochic fault system, and granitic intrusions were again emplaced. At the same time, mobilization of serpentinite occurred around the Caribbean margins, and a new set of plate movements was initiated that resulted in continued extensional faulting and subsidence at the eastern continental margin of the Yucatan Peninsula.

In Cuba, the sequence of pre-Cretaceous events is more obscure. The depositional age of the phyllites and marbles of the Sierra de Trinidad and Isla de Piños is uncertain, and the latest metamorphic episode there can be established only as pre-mid-Cretaceous on stratigraphic evidence. The age and provenance of the San Cayetano Formation are critical in the interpretation of the tectonic history of western Cuba, yet the unfossiliferous lower part of the succession can be designated only Middle Jurassic or older, and the source terrane is unknown. The correlation of the metamorphic rocks on Isla de Piños with the sedimentary rocks of the San Cayetano Formation and Viñales Limestone is tenuous at best; the alternative age assignment of the island rocks to the Paleozoic may be correct. Perhaps the phyllites of Sierra de Trinidad and Isla de Piños are equivalent to those of the Santa Rosa Group, as Murray (1961) implies in his discussion of a Paleozoic fold belt between northern Central America and western Cuba. The presence of serpentinite at station 1. suggests a southwestward continuation of the Antillean ultramafic belt and further supports the inferred link.

Although the potassium-argon measurements are inadequate for precise age determination, the dredged phyllite samples indicate a pre-Tertiary metamorphic event, and evaluation of the data suggests that this event is not as old as the Late Permian to Late Triassic orogeny in northern Central America. Isotope ages on muscovite schist from Isla de Piños reported by Meyerhoff, Khudoley, and Hatten (1969), 73 $\pm 4,76 \pm 2$, and $78 \pm 4$ m.y., indicate a metamorphic event that occurred before the end of Cretaceous time. These workers imply that the dates may be rejuvenescent as a result of degassing during an Eocene(?) thermal event and that, on the basis of stratigraphic evidence, the metamorphism was pre-Campanian.

Structural and stratigraphic interpretations seem to favor the Late Permian to Late Triassic orogenic episode as the cause of metamorphism in the Yucatan Channel. If the phyllite samples from the dredge stations and Isla de Piños correlate with the Pennsylvanian and Early Permian Santa Rosa Group, then their metamorphism predates continental rifting, and a broad distribution of similar rocks through the submerged continental remnants in the western Caribbean is to be expected. Alternatively, the San Cayetano Formation and the metamorphic rocks of Isla de Piños and Sierra de Trinidad may be equivalent and entirely of Early and Middle Jurassic age. If they are, the corresponding dredged phyllites would not correlate with the subsurface and outcrop occurrences of strikingly similar older rocks in British Honduras but would reflect a post-Middle Jurassic metamorphic event. The central Yucatan Basin apparently opened progressively southwestward by sphenochasmic rifting that began in Late Triassic or Early Jurassic time and continued through the Cretaceous (Dillon and Vedder, 1972). Extensional tectonics along the eastern continental margin of the Yucatan Peninsula during Late Jurassic through Late Cretaceous time seem to preclude regional metamorphism of preexisting continental terranes in the Yucatan Channel within the same time interval.

\section{ACKNOWLEDGMENTS}

Identification of Foraminifera and their age assignment were provided expeditiously by Ruth Todd and K. N. Sachs. L. B. Schlocker made the potassium measurements, and J.C. Von Essen did the argon measurements and calculations. H. C. MacGillavry, of the University of Amsterdam, and G.W. Moore and R.A. Loney read the manuscript and offered pertinent suggestions for its improvement. We are grateful for the assistance of the scientific party and the crew of the Unitedgeo I during the cruise. 


\section{REFERENCES CITED}

Alvarez, Manuel, Jr., 1954, Exploración geológica preliminar del Rio Hondo, Quintana Roo: Asoc. Mexicana Geólogos Petroleros Bol., v. 6, p. 207-213.

Baie, L. F., 1970, Possible structural link between Yucatan and Cuba: Am. Assoc. Petroleum Geologists Bull., v. 54, p. 2204-2207.

Bass, M. N., and Zartman, R. E., 1969, The basement of Yucatan Peninsula: EOS (Am. Geophys. Union Trans.), v. 50, no. 4, p. 313.

Bateson, J. H., 1972, New interpretation of geology of Maya Mountains, British Honduras: Am. Assoc. Petroleum Geologists Bull., v. 56, p. 956-963.

Bateson, J. H., and Hall, I. H. S., 1971, Revised geologic nomenclature for pre-Cretaceous rocks of British Honduras: Am. Assoc. Petroleum Geologists Bull., v. 55, p. 529-530.

Bohnenberger, O. H., 1966, Nomenclatura de las capas Santa Rosa en Guatemala: Inst. Centroamericano Inv. y Technología Indus. Pub. Geol., no. 1, p. 47-51.

Bryant, W. R., Meyerhoff, A. A., Brown, N. K., Jr., Furrer, M. A., Pyle, T. A., and Antoine, J.W., 1969, Escarpments, reef trends, and diapiric structures, eastern Gulf of Mexico: Am. Assoc. Petroleum Geologists, v. 53, p. 2506-2542.

Clemons, R. E., and Long, L. E., 1971, Petrologic and isotopic study of the Chiquimula pluton, southeastern Guatemala: Geol. Soc. America Bull., v. 82, no. 10, p. 2729-2740.

Cox, Allan, and Dalrymple, G. B., 1967, Statistical analysis of geomagnetic reversal data and the precision of potassium-argon dating: Jour. Geophys. Research, v. 72, no. 10, p. 2603-2614.

Dalrymple, G. B., and Lanphere, M. A., 1969, Potassium-argon datingPrinciples, techniques and applications to geochronology: San Francisco, Calif., W. H. Freeman and Co., 258 p.

Dengo, G., 1969, Problems of tectonic relations between Central America and the Caribbean: Gulf Coast Assoc. Geol. Soc. Trans., v. 19, p. $311-320$.

Dengo, G., and Bohnenberger, O. H., 1969, Structural development of northern Central America: Am. Assoc. Petroleum Geologists Mem. 11, p. 203-220.

Dillon, W. P., and Vedder, J. G., 1972, Structure and development of the continental margin of British Honduras: Geol. Soc. America Abs. with Programs, v. 4, no. 7, p. 488.

Dixon, C. G., 1956, Geology of southern British Honduras, with notes on adjacent areas: Belize Govt. Printer, 85 p.

Evernden, J. F., and Kistler, R. W., 1970, Chronology of emplacement of Mesozoic complexes in California and western Nevada: U.S. Geol. Survey Prof. Paper 623, 42 p.

Flores, G., 1952, Geology of northern British Honduras: Am. Assoc. Petroleum Geologists Bull., v. 36, p. 404-409.

Hall, I. H. S., and Bateson, J. H., 1972, Late Paleozoic lavas in Maya Mountains, British Honduras, and their possible regional significance: Am. Assoc. Petroleum Geologists Bull., v. 56, p. 950-953.

Hatten, C. W., 1967, Principal features of Cuban geology: Am. Assoc. Petroleum Geologists Bull., v. 51, p. 780-789.

Hatten, C. W., and Meyerhoff, A. A., 1970, The Caribbean area: a case of destruction and regeneration of a continent: Geol. Soc. America Bull., v. 81, p. 1855-1862.

Hill, P. A., 1959, Geology and structure of the northwest Trinidad Mountains, Las Villas Province, Cuba: Geol. Soc. America Bull., v.
70 , p. $1459-1478$

Kesler, S. E., 1971, Nature of ancestral orogenic zone in nuclear Central America: Am. Assoc. Petroleum Geologists Bull., v. 55, p. 2116-2129.

Kesler, S. E., Bateson, J. H., Josey, W. L., Cramer, G. H., and Simmons, W. A., 1971, Mesoscopic structural homogeneity of Maya Series and Macal Series, Mountain Pine Ridge, British Honduras: Am. Assoc. Petroleum Geologists Bull., v. 55, no. 1, p. 97-103.

Khudoley, K. M., 1967, Principal features of Cuban geology: Am. Assoc. Petroleum Geologists Bull., v. 51, p. 668-677.

Khudoley, K. M., and Meyerhoff, A. A., 1971, Paleogeography and geologic history of Greater Antilles: Geol. Soc. America Mem. 129, $199 \mathrm{p}$.

Khudoley [Judoley], K. M., Krasnor, V. I., Novojasky, I. P., and Skriabina, E., eds., 1963, Mapa de Yacimientos minerales de Cuba: Cuba Inst. Recursos Minerales, 4 sheets, 1:500,000. [1965]

Kuman, V.E., and Gavilán, R. R., 1965, Geología de Isla de Piños: Nuestra Industria-Rev. Tecnológica, v. 3, no. 4, p. 20-38.

McBirney, A. R., 1963, Geology of a part of the central Guatemala Cordillera: California Univ. Pubs. Geol. Sci., v. 38, no. 4, p. $177-242$.

McBirney, A. R., and Bass, M. N., 1969, Structural relations of pre-Mesozoic rocks of northern Central America: Am. Assoc. Petroleum Geologists Mem. 11, p. 269-280.

MacGillavry, H. J., 1970, Geological history of the Caribbean: Koninkl Nederlandse Akad. Wetensch. Proc., ser. B, v. 73, no. 1, p. 64-96.

Meyerhoff, A. A., and Hatten, C. W., 1968, Diapiric structures in central Cuba: Am. Assoc. Petroleum Geologists Mem. 8, p. 315-357.

Meyerhoff, A. A., Khudoley, K. M., and Hatten, C. W., 1969, Geologic significance of radiometric dates from Cuba: Am. Assoc. Petroleum Geologists Bull., v. 53, p. 2494-2500.

Mina V., Federico, 1966, Petroleum developments in Mexico in 1965: Am. Assoc. Petroleum Geologists Bull., v. 50, p. 1553-1563.

Murray, G. E., 1961, Geology of the Atlantic and Gulf coastal province of North America: New York, Harper and Bros., 692 p.

Page, L. R., and McAllister, J. F., 1944, Tungsten deposits, Isla de Piños, Cuba: U.S. Geol. Survey Bull. 935-D, p. 177-246.

Palmer, R. H., 1945, Outline of the geology of Cuba: Jour. Geology, v. 53 , no. 1, p. $1-34$.

Rutten, L. M. R., 1934, Geology of Isla de Piños, Cuba: Koninkl. Akad. Wetensch. Amsterdam, Sec. Sci. Proc., v. 37, no. 7, p. 401-406.

Skvor, Vladimir, 1969, The Caribbean area: a case of destruction and regeneration of a continent: Geol. Soc. America Bull., v. 80, p. 961-968.

Tijomirov, I. N., 1967, Formaciones magmaticas de Cuba y algunas particularidades de su metalogenia: Nuestra Industria-Rev. Technológica, v. 5, no. 4, p. 13-22 [1968]

Vedder, J. G., and others, 1971, USGS-IDOE Leg 2: Geotimes, v. 16, p. 10-12.

Vedder, J. G., and others, 1972, Acoustic reflection profiles-East margin, Yucatan Peninsula: U.S. Geol Survey Rept. USGS-GD. 70-003, 33 p.; available only from U.S. Dept. Commerce Natl. Tech. Inf. Service, Springfield, Va. 22151, as Rept. PB2-0795.

Viniegra, O.F., 1971, Age and evolution of salt basins of southeastern Mexico: Am. Assoc. Petroleum Geologists Bull., v. 55, p. 478-494.

Williams, H., and McBirney, A. R., 1969, Volcanic history of Honduras: California Univ. Pubs. Geol. Sci., v. 85, 101 p. 


\title{
GEOLOGY OF PART OF THE SOUTHERN COMPLEX, MARQUETTE DISTRICT, MICHIGAN
}

\author{
By W. F. CANNON and GEORGE C. SIMMONS, \\ Washington, D.C., Denver, Colo. \\ Work done in cooperation with the Geological Survey Division, \\ Michigan Department of Natural Resources
}

\begin{abstract}
The southern complex, south of the Marquette synclinorium in the Marquette district of Michigan, is dominantly granitic. The granitic parts of the complex have $\mathrm{Rb}-\mathrm{Sr}$ ages of about $2.5 \mathrm{~b}$.y. and are classed as of Precambrian $\mathrm{W}$ age. The rocks are divided into two major units: (1) Bell Creek Gneiss consisting mostly of coarse megacrystic granitic rocks and lesser amounts of mafic gneiss and metasedimentary rocks in layers concordant to the foliation of the granitic gneiss, and (2) Compeau Creek Gneiss, previously described to the east, which is mostly medium-grained granitic gneiss and lesser amounts of massive granitic rocks and locally abundant xenoliths of mafic and metasedimentary rocks. Compeau Creek Gneiss intrudes Bell Creek Gneiss throughout the area. Mafic and metasedimentary rocks in the Bell Creek Gneiss are interpreted as remnants of a greenstone belt. The granitic parts of the Bell Creek Gneiss are of problematic origin. Their composition suggests a magmatic origin, but they do not intrude any rocks with which they are in contact; they form concordant layers in all observed places. Granitic parts of the Compeau Creek Gneiss are suspected to be highly altered and partly melted sedimentary rocks. The mafic parts are probably xenoliths of mafic rocks from the Bell Creek Gneiss.
\end{abstract}

The Marquette district is in the Northern Peninsula of Michigan (fig. 1), and has been famous as a producer of iron ore during the past 120 years. Because of its economic importance, the district has been extensively studied, and the literature describing the iron-bearing formation and the rocks folded with it in the Marquette synclinorium is voluminous. Rocks south of the synclinorium, in what has become known as the southern complex, have received less attention', and the extant literature presents a confusing and contradictory account of the geology. Recent detailed mapping by the U.S. Geological Survey provides significant data for the geologic interpretation of this area.

This paper describes the lithology, distribution, and age of rocks of part of the southern complex underlying about 110 sq mi within the Ishpeming, Greenwood, and Republic 71/2minute quadrangles, and introduces a new stratigraphic name for a major gneiss unit. The origin of many of the rock types is

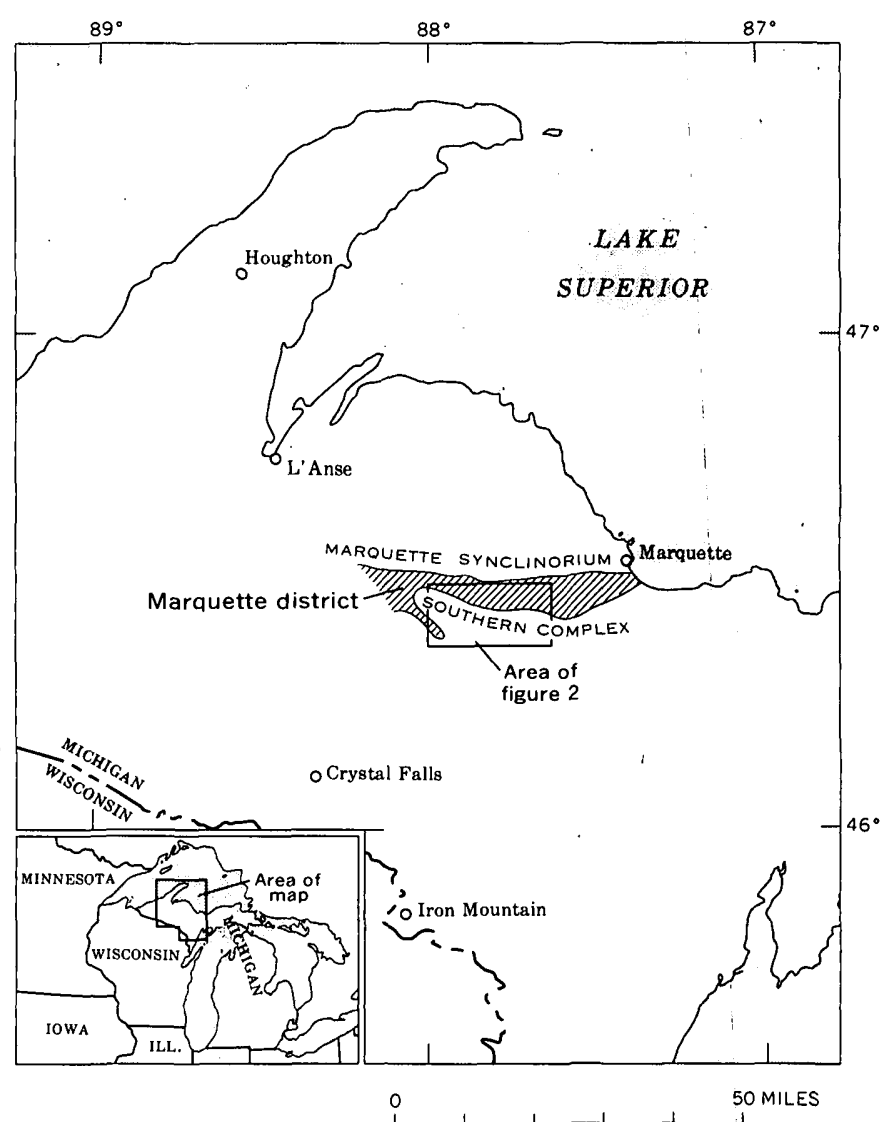

Figure 1.-Map showing the location of the Marquette district, Marquette synclinorium (diagonal pattern), and the southern complex.

problematical, is still under study, and is mentioned only briefly.

\section{PREVIOUS WORK}

A variety of stratigraphic names has been used for rocks in 


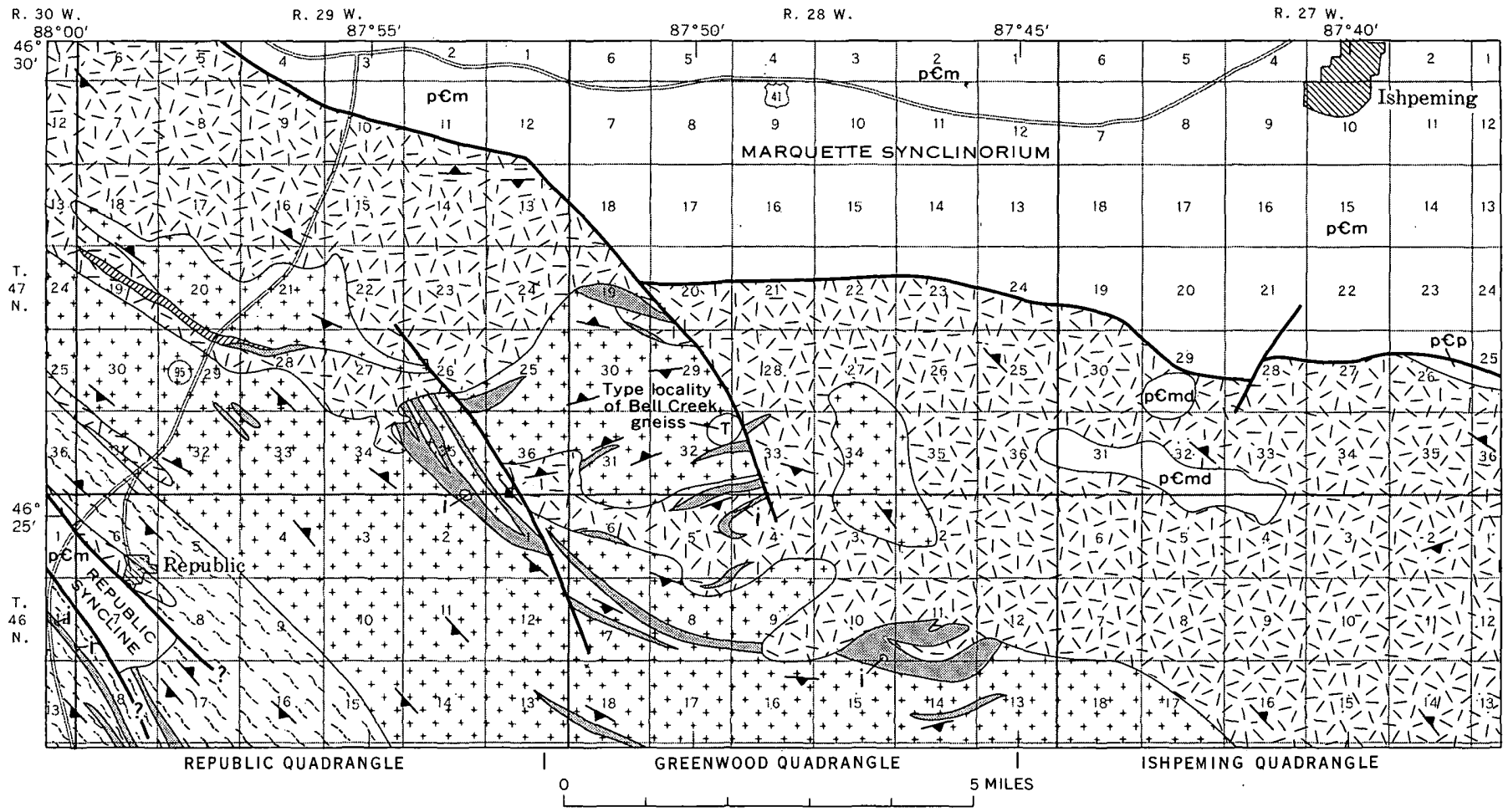

Figure 2.-Generalized geologic map of the southern complex in the Republic, Greenwood, and Ishpeming 71/2-minute quadrangles, Michigan.

the Marquette district. Rocks presently called Precambrian W have also been called "Archean" and lower Precambrian. The Marquette Range Supergroup (Precambrian X) has been called middle Precambrian, Animikie Series, and Huronian. In this report, the terms in quotation marks are those used by the author to which reference is made.

The name "southern complex" was introduced by Van Hise and Bayley (1897) for the crystalline rocks south of the Marquette synclinorium; although they did not map the area, they published the first detailed petrographic descriptions of the rocks, which they considered "Archean." Lamey (1931, $1933,1934,1935)$ disagreed with Van Hise and Bayley and presented evidence for a "post-Huronian" age (post-Marquette Range Supergroup of present usage) for the granitic rocks. In response to Lamey's work, Dickey (1936) reasserted an "Archean" age for these rocks and described relations indicating two ages of "Archean" granite. Later, Dickey (1938) changed his opinion and adopted a "post-lower Huronianpre-middle Huronian" age for the southern complex (postChocolay Group-pre-Menominee Group of present usage), on the basis of intrusive relations with supposed "lower Huronian" rocks in northern Dickinson County. Snelgrove, Seaman, and Ayres (1944) described intrusive relations near Republic and concluded that the granitic rocks of the southern complex were entirely "post-Huronian." James $(1955,1958)$ reasserted a "lower Precambrian" age for the granitic rocks because they are intruded by diabase dikes that are older than the Precambrian X Penokean orogeny. Dickey's earlier interpretation
(1936) was invalidated because his "lower Huronian" rocks were reassigned a "lower Precambrian" age (Dickinson Group). Taylor (1967) studied structures in the western part of the area discussed in this paper, proposed a sequence of multiple intrusion and deformation, and suggested that a major part of the southern complex is of "post-Animikie" age. Gair and Thaden (1968) described in detail part of the southern complex near the east end of the Marquette Range and presented evidence indicating a "lower Precambrian" age. Zainuddin (1971) described the petrology of granitic rocks near Republic and devised a tripartite division based on lithology. Although his division is similar to ours, the relative ages that he suggested are the reverse of those which we propose later in this paper. He suggested that a major part of the southern complex is "post-Animikie," but this is refuted by radiometric dates by Woolsey (1971), which show that all major granitic units in our map area are of Precambrian $W$ age.

\section{GENERAL GEOLOGY}

The rocks of the southern complex are chiefly granitic gneisses and lesser amounts of mafic gneiss, massive granitic rocks, migmatite, and highly metamorphosed rocks of probable metasedimentary origin. Our mapping has defined two major units whose distribution is shown in figure 2: (1) an older unit, here named the Bell Creek Gneiss, and (2) the Compeau Creek Cneiss, a unit first described by Gair and Thaden (1968) near the east end of the Marquette Range. 


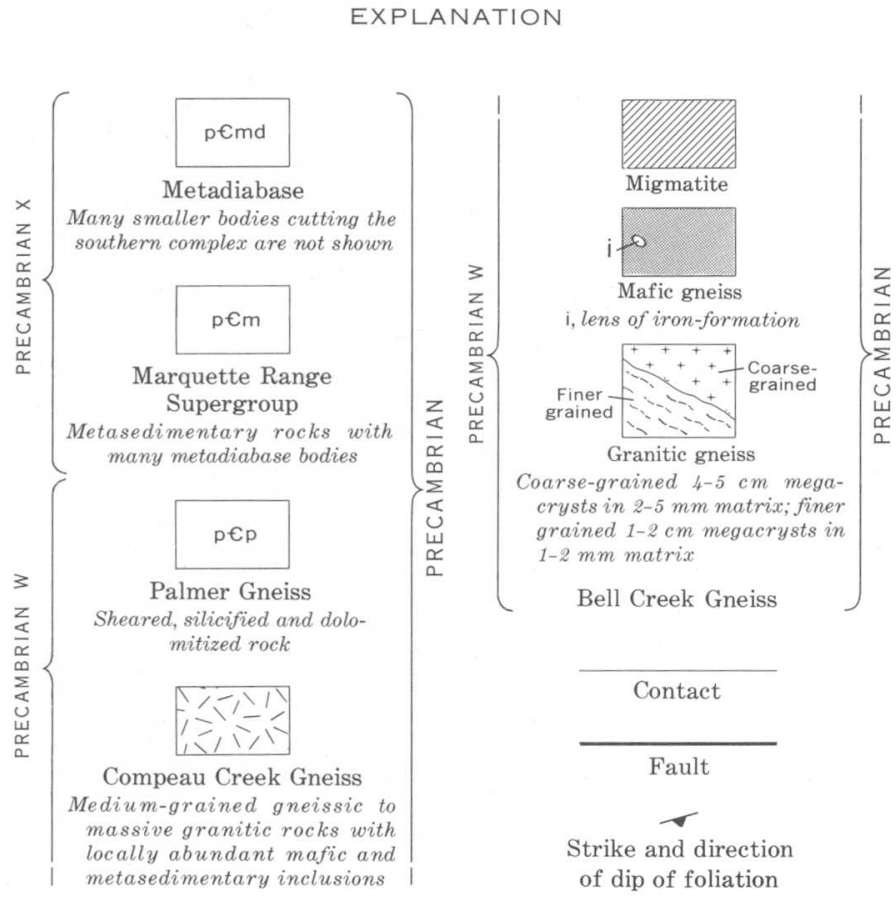

Figure 2.

The Bell Creek Gneiss consists largely of very coarse grained megacrystic ${ }^{1}$ granitic rocks, mostly of adamellite composition, and lesser amounts of mafic gneiss containing lenses of iron-formation. Migmatite forms a small part of the Bell Creek Gneiss in the Republic quadrangle.

The Compeau Creek Gneiss consists mostly of foliated granodiorite and tonalite containing locally abundant inclusions of amphibolitic gneiss; gneisses of adamellite and monzonitic composition, and granite, are less common. The Compeau Creek Gneiss truncates units of the Bell Creek Gneiss in many places. Figure 3, for example, shows crosscutting relationships near the type locality of the Bell Creek Gneiss where megacryst foliation in the Bell Creek granitic gneiss is truncated by a dike of Compeau Creek granitic gneiss. The granitic rocks of the southern complex lack crosscutting relations with the rocks of the Marquette Range Supergroup, which are folded in the Marquette synclinorium, but like the Marquette Range Supergroup, they are cut by dikes of metadiabase which are older than the late Precambrian X Penokean orogeny. Thus, the formation of the southern complex must likewise predate the Penokean orogeny. Because there are no other thermal events in Precambrian $X$ time to which the rocks of the southern complex can be related, they must have formed during one or more Precambrian W orogenies.

The southern complex was deeply eroded and probably peneplaned before the deposition of the Marquette Range

\footnotetext{
${ }^{1}$ Because the origin of these rocks is undetermined, the term "megacryst" is used for those grains in an inequigranular rock that are distinctly larger than grains of the groundmass. Terms such as "phenocryst" and "porphyroblast," that imply an origin, are avoided.
}

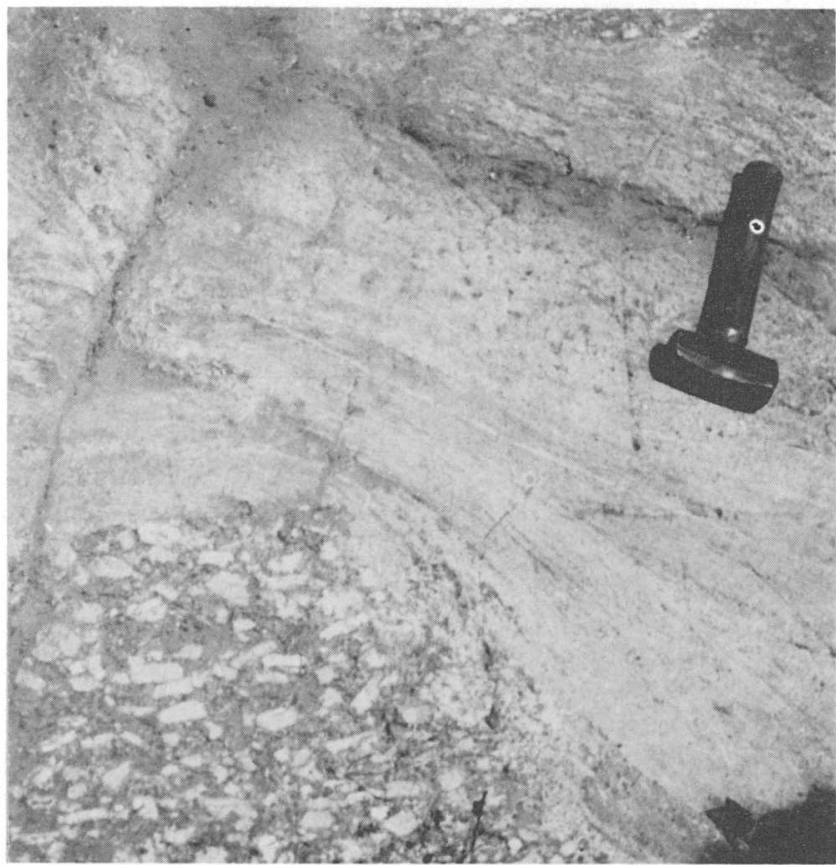

Figure 3.-Dike of Compeau Creek Gneiss (finer grained) cutting foliation of Bell Creek Gneiss (coarser grained rock in lower left). Outcrop at type locality of Bell Creek Gneiss, NW1/4, sec. 32, T. 47 N., R. 28 W. Hammer about 10 inches long.

Supergroup. Before being folded in the Marquette synclinorium and Republic syncline, the Marquette Range Supergroup unconformably overlay the southern complex but is now in fault contact with it in most of the area.

The southern complex is cut by mafic dike rocks of probably two Precambrian X ages (both sets of rocks having been metamorphosed by the late Precambrian X Penokean orogeny) and by nonmetamorphosed diabase dikes of Keweenawan age.

Pegmatite dikes, which are most abundant in the southern complex near Republic, are similar both texturally and mineralogically to pegmatites that cut Precambrian $\mathrm{X}$ rocks in the Republic syncline and are believed to be the only Precambrian $\mathrm{X}$ granitic rocks in the complex. They are rare and form only a small part of the southern complex.

Although the southern complex predates the Penokean orogeny, it was little affected by that orogeny; all folds in the complex, and most of the mineralogic features, are the result of one or more Precambrian W orogenies. Folds in the gneissic rocks are cut by metadiabase dikes which are older than the Penokean orogeny but are not folded, indicating that no Penokean folding of the gneissic rocks occurred. Some sheared zones and locally penetrative shear foliation, most conspicuous near Republic, may have formed during the Penokean orogeny. Mineral assemblages in the Precambrian W rocks are unrelated to the isograds of Penokean regional metamorphism defined from Precambrian X rocks by James (1955). Assemblages in Precambrian $W$ rocks generally indicate meta- 
morphism more intense than the Penokean metamorphism. Retrograde metamorphism of the high-grade Precambrian W assemblages was minimal during the Penokean metamorphism, probably because of a scarcity of water, which prevented rehydration of the largely dehydrated Precambrian W assemblages.

\section{BELL CREEK GNEISS}

The rocks here named Bell Creek Gneiss are a layered sequence of coarse-grained megacrystic granitic gneiss and concordant layers, some 1,000 feet or more thick, of mostly moderately to weakly foliated mafic gneiss. At several localities, lenses of highly metamorphosed iron-formation are within the mafic gneiss. Near Republic is a belt 3-4 miles wide of finer grained megacrystic granite. Thin layers, most only a few feet thick, are rare but widely distributed and consist of fineto medium-grained granite and rarely of biotitic or hornblendic quartzite. The Bell Creek also includes one conspicuous unit of migmatite. The Bell Creek Gneiss is named for Bell Creek in the Greenwood quadrangle, and the type locality is in secs. 32 and 33, T. 47, N., R. $28 \mathrm{~W}$., where most phases of the gneiss are well exposed along the valley of Bell Creek and in artificial exposures along a recently constructed pipeline.

Granitic gneiss.-The most abundant rock type in the Bell Creek Gneiss is coarse-grained granitic gneiss, a very distinctive rock consisting of large pink megacrysts of microcline microperthite, typically 4-5 cm long, set in a coarse matrix of quartz, feldspar, and biotite with an average grain size of $2-5 \mathrm{~mm}$ (fig. 4). Pink, white, and gray are common colors for both weathered and fresh surfaces. The megacrysts are commonly carlsbad twins and are generally moderately to strongly alined, which imparts a distinctly gneissic appearance. Layers 1 to 5 feet thick are apparent in some outcrops because of variations in the abundance of megacrysts. The composition of the groundmass is uniform, regardless of the concentration of the megacrysts, and the layers are parallel to the gneissic structure (alinement of the megacrysts).

The mineralogic and chemical compositions are relatively homogeneous, as indicated by the proportions of quartz, plagioclase, and potassium feldspar plotted in figure $5 \mathrm{~A}$ and the chemical analyses in table 1 . The rock is predominantly adamellite with lesser amounts of granodiorite and granite; tonalite is rare.

A finer grained phase of this rock occurs in a belt 3 to 4 . miles wide in the southwest corner of the mapped area (fig. 2); the belt trends parallel to the northwest strike of the regional foliation and appears to be a concordant body in the coarser grained gneiss. The northeast contact of this unit is gradational; the grain size gradually increases across a zone roughly a few hundred feet wide in which the finer grained rocks pass into typical coarse-grained granitic gneiss. The southwest contact of this unit is southwest of the map area; here, also, reconnaissance indicates that the finer grained rocks pass into typical coarse-grained granitic gneiss. In hand specimen, the

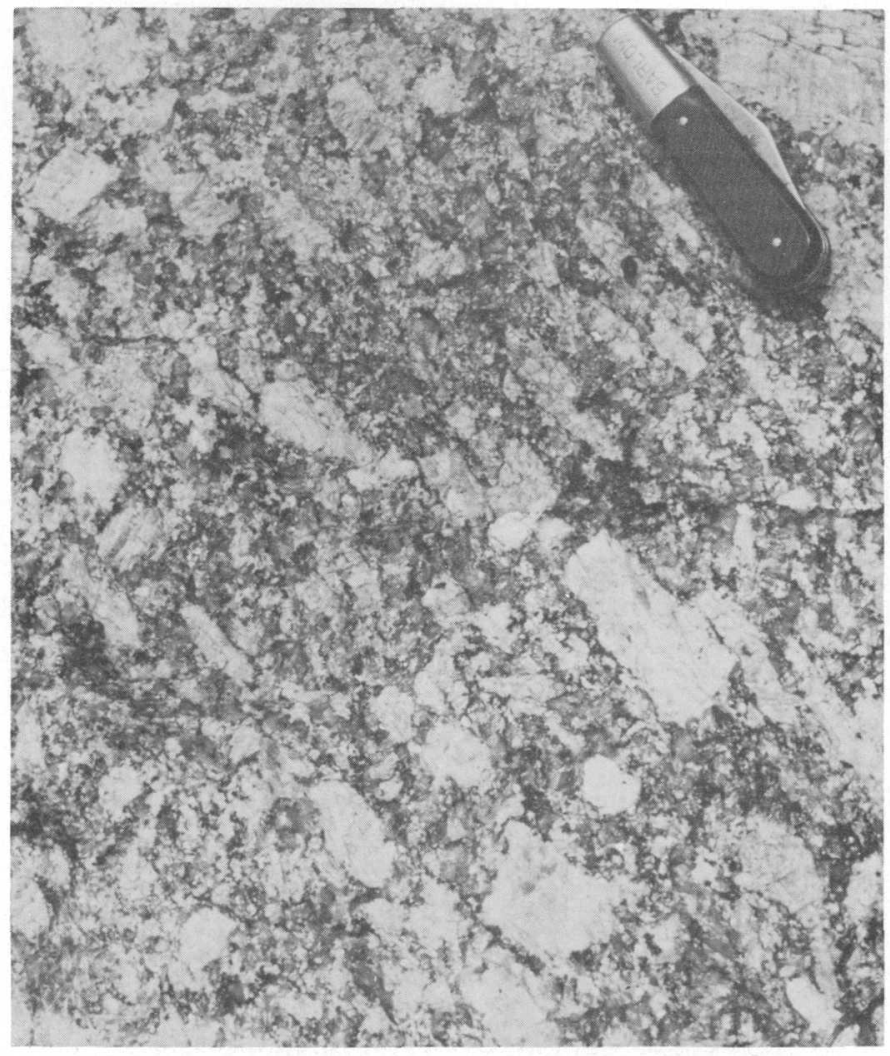

Figure 4.-Granitic phase of Bell Creek Gneiss at type locality in pipeline cut 100 feet west of Marquette County Road 478; $500 \mathrm{ft} \mathrm{S}$, $2,000 \mathrm{ft} \mathrm{W.,} \mathrm{NE} \mathrm{cor.} \mathrm{sec.} 32$, T. 47 N., R. 28 W.

rock is mineralogically identical to the coarser grained variety and is texturally similar, except for the diminished size of all components. Microcline megacrysts are $1-2 \mathrm{~cm}$ long, and groundmass grains are about $1-2 \mathrm{~mm}$.

Mafic gneiss.-Layers of mafic gneiss of mappable extent are common and widely distributed throughout the granitic gneiss. They occur parallel to the foliation of the granitic gneiss, and intrusion of one rock by the other has not been found. The most common mafic gneiss is black to dark green and chiefly consists of plagioclase and hornblende, and, locally, clinopyroxene. In outcrop, the clinopyroxene is generally distinguishable from hornblende by its somewhat golden-weathering surface which is distinct from the black hornblende. The texture is characteristically granoblastic, with little preferred orientation of grains, and is distinct from the relict diabasic texture of younger mafic rocks. Equant grains $1 \mathrm{~mm}$ across are typical. In hand specimen, the rock is either massive or compositionally layered, but at outcrop scale some compositional layering can always be found, even where the rock is largely massive. In a few places, the rock contains elongated ellipsoidal structures suggestive of stretched pillows.

Mafic rocks, in masses too small to show on figure 2, are widely distributed throughout the Bell Creek Gneiss. The relative age of these rocks is commonly difficult to determine, but it is clear that these rocks are of several different ages and 

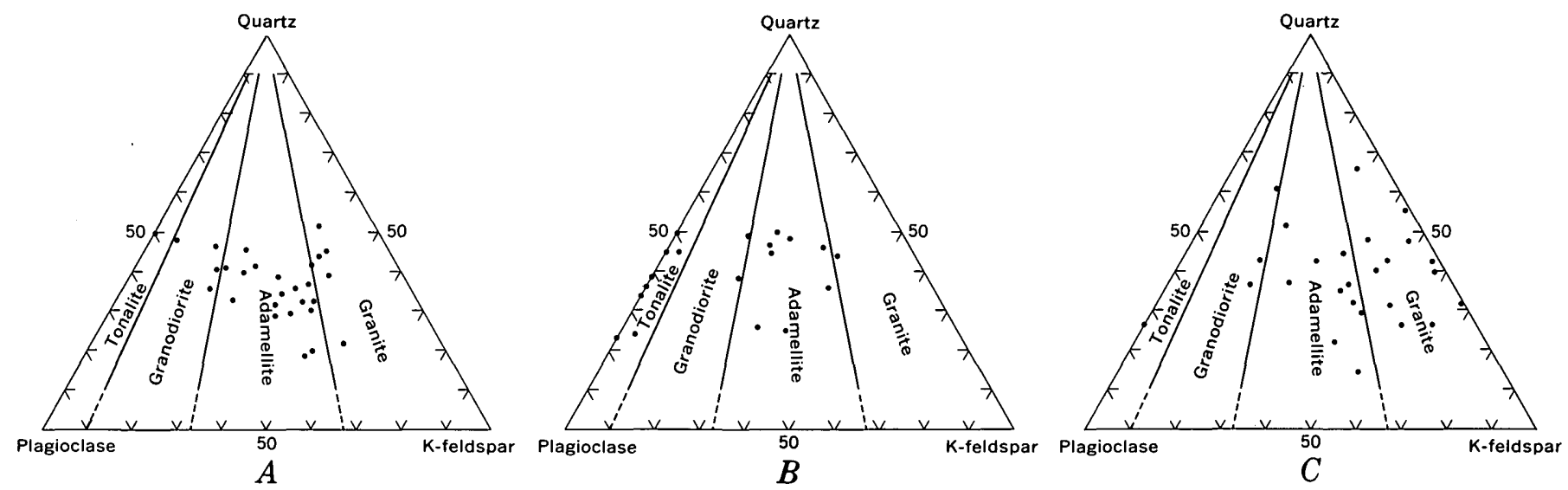

Figure 5.-Ternary diagrams showing the relative modal proportions of quartz, plagioclase (mostly oligoclase), and potassium feldspar in granitic gneiss of the Bell Creek Gneiss $(A)$, granitic gneiss of the Compeau Creek Gneiss $(B)$, and massive granitic rocks of the Compeau Creek Gneiss $(C)$.

Table 1.-Chemical analyses of rocks from the southern complex, Marquette district, Michigan [Method used was a single-solution procedure described by Shapiro (1967)]

\begin{tabular}{|c|c|c|c|c|c|c|c|c|c|c|c|}
\hline Field No. & GS-1-71. & GS-2-71 & GS-3-71 & GS-35-71 & GS-36-71 & GS-38-71 & GS-40-71 & GS-41.71 & GS-43-71 & GS-44-71 & GS-45-71 \\
\hline $\mathrm{SiO}_{2}$ & 74.2 & 73.4 & 74.0 & 74.9 & 75.1 . & 74.5 & 49.3 & 47.1 & 71.2 & 51.0 & 75.7 \\
\hline $\mathrm{Al}_{2} \mathrm{O}_{3}$ & 13.7 & 13.7 & 13.5 & 12.4 & 12.9 & 13.7 & 15.8 & 13.7 & 14.0 & 15.7 & 13.3 \\
\hline $\mathrm{Fe}_{2} \mathrm{O}_{3}$ & .50 & .50 & .50 & .40 & .18 & .30 & 1.2 & 2.0 & .30 & 1.2 & .40 \\
\hline $\mathrm{FeO}$. & 1.4 & 1.6 & 1.8 & 1.4 & .32 & .84 & 10.2 & 11.4 & 2.4 & 10.9 & .68 \\
\hline $\mathrm{MgO}$ & .42 & .51 & .39 & .60 & .24 & .60 & 6.4 & 8.9 & 1.2 & 8.5 & .21 \\
\hline $\mathrm{CaO}$ & 1.1 & 1.5 & 1.1 & 1.7 & .12 & 1.8 & 12.1 & 11.9 & 3.9 & 1.6 & .16 \\
\hline $\mathrm{Na}_{2} \mathrm{O}$ & 2.6 & 2.9 & 2.6 & 2.4 & 2.0 & 3.5 & 2.4 & 1.3 & 4.1 & .70 & 2.2 \\
\hline $\mathrm{K}_{2} \mathrm{O}$ & 5.4 & 4.7 & 4.8 & 5.0 & 7.0 & 4.5 & .53 & .50 & 1.2 & 4.1 & 6.1 \\
\hline $\mathrm{H}_{2} \mathrm{O}+$ & .84 & .83 & .40 & .78 & .47 & .71 & 1.6 & $1.4^{\circ}$ & .86 & 4.0 & .71 \\
\hline $\mathrm{H}_{2} \mathrm{O}-$ & .09 & .09 & .65 & .04 & .01 & .09 & .03 & .03 & .02 & .12 & .05 \\
\hline $\mathrm{TiO}_{2}$ & .24 & .28 & .29 & .15 & .03 & .09 & .89 & .93 & .38 & 2.2 & .07 \\
\hline $\mathrm{P}_{2} \mathrm{O}_{5}$ & .06 & .06 & .10 & .17 & .00 & .00 & .08 & .06 & .24 & .12 & .01. \\
\hline $\mathrm{MnO}$ & .05 & .05 & .05 & .07 & .06 & .05 & .18 & .22 & .41 & .04 & .19 \\
\hline $\mathrm{CO}_{2}$ & .06 & .02 & .26 & .22 & .15 & .10 & .10 & .09 & .14 & .06 & .08 \\
\hline Sum & 101 & 100 & 100 & 100 & 99 & 101 & 101. & 100 & 100 & 100 & 100 \\
\hline
\end{tabular}

Locations of samples:

GS-1-71. Bell Creek Gneiss, bridge abutment on north side of Middle Branch, Escanaba River, 2,200 ft S., 1,550 ft W., NE cor. sec. 13, T. 46 N., R. 28 W.

GS-2-71. Bell Creek Gneiss, $560 \mathrm{ft} \mathrm{S.,} 0 \mathrm{ft}$ W., NE cor. sec. 18, T. 46 N., R. 27 W. (on section line of secs. 17 and 18).

GS-3-71. Bell Creek Gneiss, type locality on pipeline $100 \mathrm{ft}$ W. of Marquette County Road 478, $500 \mathrm{ft} \mathrm{S.,} \mathrm{2,000} \mathrm{ft} \mathrm{W.,} \mathrm{NE} \mathrm{cor.} \mathrm{sec.}$ 32, T. 47 N., R. 28 W.

GS-35-71. Compeau Creek Gneiss, granitic phase, 2,000 ft S., 2,080 ft E., NW cor. sec. 1, T. 46 N., R. 27 W.

GS-36-71. Compeau Creek Gneiss, Granitic phase, $400 \mathrm{ft} \mathrm{S.,} 2,060$ ft W., NE cor. sec. 3; T. 46 N., R. 27 W.

are in part younger than the large mafic gneiss masses shown on figure 2.

Iron-formation.-At several localities are lenses of highly metamorphosed iron-formation (see fig. 2) in mafic gneiss. The iron-formation consists of grunerite, iron-rich orthopyroxene and clinopyroxene, garnet, magnetite, and quartz in various
GS-38-71. Compeau Creek Gneiss (weakly foliated gneiss), 1,760 ft S., 2,540 ft E., NW cor. sec. 14, T. 46 N., R. 27 W.

GS-40-71. Compeau Creek Gneiss, amphibole gneiss, 1,640 ft N., $2,000 \mathrm{ft}$ E., SW cor. sec. 15, T. 46 N., R. 27 W.

GS-41-71. Compeau Creek Gneiss, amphibole gneiss, 1,500 ft N., $1,550 \mathrm{ft}$ W., SE cor. sec. 15, T. 46 N., R. 27 W.

GS-43-71. Compeau Creek Gneiss, 2,300 ft S., 2,200 ft E., SW cor. sec. 10, T. 46 N., R. $27 \mathrm{~W}$.

GS-44-71. Compeau Creek Gneiss, amphibole gneiss, $1,300 \mathrm{ft} \mathrm{N}$., $2,550 \mathrm{ft}$ W., SE cor. sec. 30, T. 47 N., R. 27 W.

GS-45-71. Compeau Creek Gneiss, garnetiferous granodiorite, 2,550 ft N., 650 ft E., SW cor. sec. 29, T. 47 N., R. 27 W.

combinations. The average grain size is $1 \mathrm{~mm}$. Most ironformation is layered; the layers are $1.2-1$ inch thick. The iron-formation is pale brown or green on fresh surfaces and weathers buff. Layers of nearly pure quartz are common, and although coarse grained now, they were probably originally chert. Magnetite content is generally less than 1.0 percent, but 
may be as much as 30 percent. Although the iron-formation units are generally small, being at most about 100 feet thick and probably no more than a few thousand feet long, some are reflected as northwest-trending positive magnetic anomalies on aeromagnetic maps (Case and Gair, 1965). Other northwesttrending anomalies over the southern complex may be caused by unexposed units of iron-formation.

Migmatite.--In the Republic quadrangle, a layer of migmatite lies between the Bell Creek granitic gneiss on the north and the Compeau Creek Gneiss on the south. The migmatite layer is nearly 1,000 feet in maximum thickness and has been mapped for about 3 miles along the strike. It terminates to the northwest in a poorly exposed area where it strikes directly into the Compeau Creek Gneiss; to the southeast it pinches out between Bell Creek granitic and mafic gneiss (fig. 2). The unit consists of conspicuously layered rocks, the layers typically $1-2$ feet thick and composed of light- to dark-gray quartzo-feldspathic gneiss with variable amounts of mafic minerals, mostly biotite. These layers are interlayered with pink to white, gneissic to massive granitic gneiss of the Compeau Creek Gneiss. The migmatite is believed to have originally been a unit of metasedimentary rocks within the Bell Creek Gneiss which was later migmatized during emplacement of the Compeau Creek Gneiss.

Other lithologies.-A very small volume of the Bell Creek Gneiss consists of layers of biotitic and hornblendic quartzite and fine- to medium-grained granitic rocks. These occur as layers as much as a few feet thick which are parallel to the foliation of granitic or mafic gneiss.

\section{COMPEAU CREEK GNEISS}

The Compeau Creek Gneiss was named and described by Gair and Thaden (1968) from its type locality in the northern complex, north of the Marquette synclinorium. Although there is no surface continuity between gneisses on opposite sides of the synclinorium, the gneisses were correlated on the basis of lithologic and structural similarities, and Gair and Thaden mapped the Compeau Creek Gneiss in both the northern and southern complexes near the east end of the Marquette Range. Later, Gair (1968) mapped the Compeau Creek Gneiss westward in the southern complex to the east boundary of the area discussed in this paper, and the same rocks crop out in a large part of our map area. In addition to the large areas shown in figure 2, Compeau Creek Gneiss occurs as bodies too small to be shown, which intrude the Bell Creek Gneiss at many other localities.

Massive and gneissic granitic rocks.-Most of the Compeau Creek Gneiss consists of granitic rocks which vary from gneissic to massive. They are distinct from the granitic gneiss of the Bell Creek Gneiss in their finer grain size, tendency toward more sodic composition, and common intermingling of rock types on outcrop scale. The rocks in the Compeau Creek are mostly equigranular and medium grained. Crystals larger than a few millimeters in diameter occur mostly with peg- matitic clots and veins, or more rarely as individual roughly euhedral microcline megacrysts as much as 2 inches long. Modal compositions are shown in figures $5 B$ and $C$, and chemical analyses appear in table 1 . Gneissic rocks are more abundant than massive rocks and are mostly tonalite and adamellite in composition, with lesser amounts of granodiorite and granite (fig. $5 B$ ). The massive rocks are chiefly granite and adamellite (fig. $5 C$ ). Layering is best shown by biotitic layers and schlieren, or in some cases by alinement of biotite, chlorite, and biotite-garnet and chlorite-garnet clots. These clots are generally about $0.5 \mathrm{~cm}$ in diameter and consist of randomly oriented biotite flakes; some clots contain cores of one or more fragments of anhedral garnet. In many areas, the massive granitic rocks contain abundant layers and xenoliths of older gneissic rocks of probable metasedimentary origin.

Amphibolite.-Small bodies of amphibolite are common within the Compeau Creek granitic gneiss. Most are represented by a single outcrop or parts of an outcrop, and many are clearly xenoliths. All are too small to be represented on figure 2 .

The rocks are typically light to dark green and, at most places, are conspicuously gneissic (fig. 6A). They consist mostly of hornblende and plagioclase with minor amounts, usually less than 5 percent, of quartz. They commonly show a strong preferred orientation of $c$-axes of hornblende, and some are compositionally layered on a scale of a few inches. In places they are feldspathized by reaction with Compeau Creek granitic rocks (fig. $6 B$ ).

\section{STRUCTURE}

The most conspicuous structural feature of the Bell Creek Gneiss is the west to northwest trend of lithologic units and foliation. Emplacement of Compeau Creek granitic rocks obscured earlier structures of the Bell Creek Gneiss in much of the area, but the distribution of foliation-plane attitudes of the Bell Creek and trends of units suggests a northwest-plunging antiform. Immediately west of our map area, reconnaissance mapping by Taylor (1967), involving the tracing of migmatitic and granitic units, indicates closure on this northwest-plunging structure. The emplacement of the Compeau Creek Gneiss occurred, at least in part, independently of the structures in the Bell Creek Gneiss, but offshoots and satellitic bodies from the main mass of Compeau Creek Gneiss are commonly elongated parallel to the regional trend of the Bell Creek Gneiss. Foliation in the Compeau Creek Gneiss is also mostly west and northwest, but much of the unit is largely structureless, and no large-scale structures are evident.

\section{AGE}

The age of the southern complex has been debated for many years. Although many authors have favored a post-Marquette Range Supergroup age for at least part of the complex, their evidence is equivocal. Our observations agree with relations 

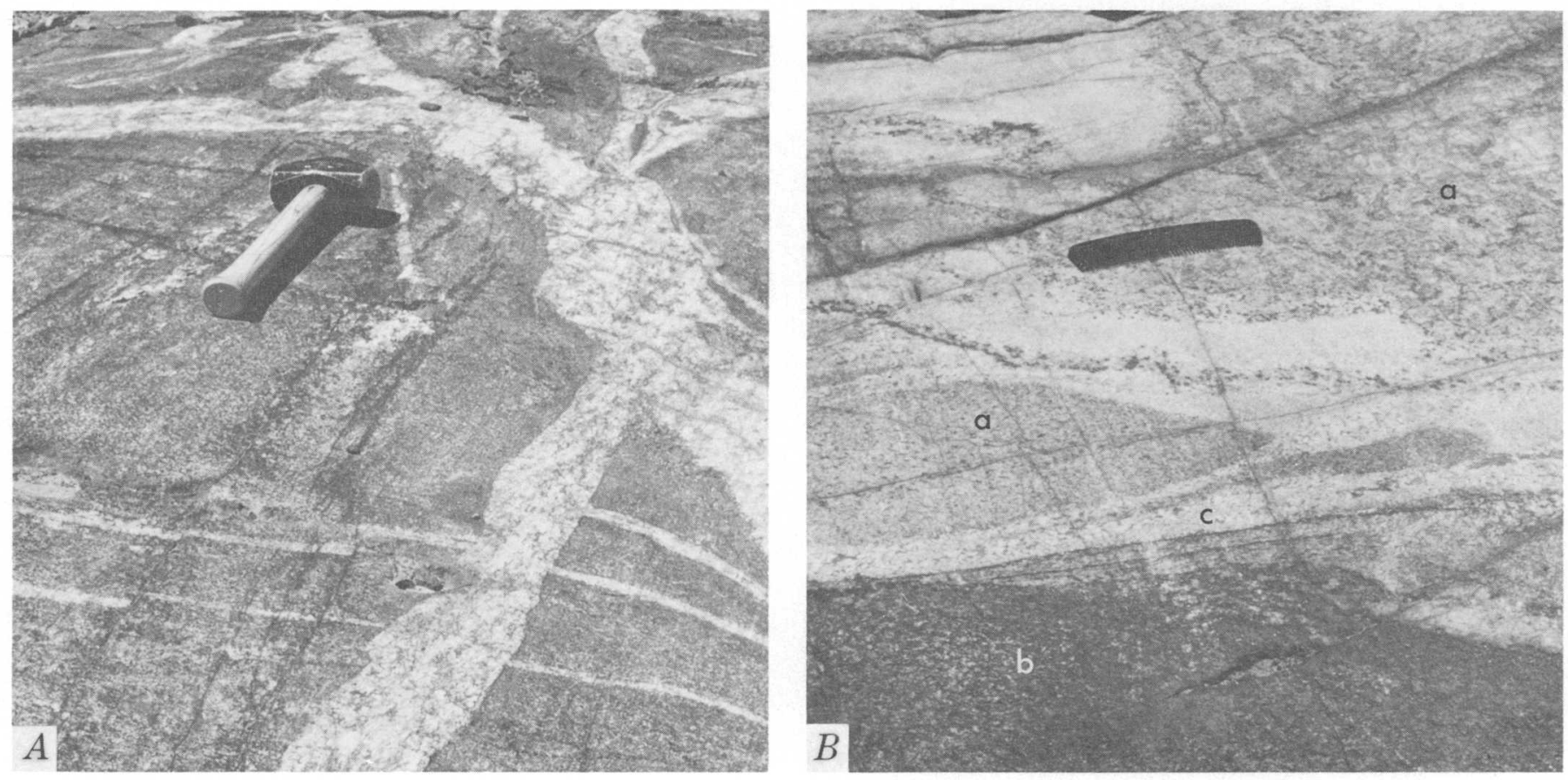

Figure 6.-Compeau Creek Gneiss.

A. Amphibolite cut by dikes of granitic pegmatite; $2,400 \mathrm{ft}$ N., $500 \mathrm{ft}$ W., SE cor. sec. 9, T. 46 N., R. 27 W.

B. Chloritic, biotitic, and hornblendic gneiss (a), presumably derived from amphibolite (b), at the time of emplacement of granitic pegmatite (c); 2,400 ft N., $500 \mathrm{ft}$ W., SE cor. sec. 9, T. 46 N., R. $27 \mathrm{~W}$.

presented by James $(1955$, 1958) and Gair and Thaden (1968). In our opinion, the general lack of crosscutting relationships of the granitic rocks of the southern complex to rocks of the Marquette Range Supergroup (a few pegmatites cut the Marquette Range Supergroup as well as the southern complex) and the presence of pre-Penokean diabase dikes cutting all major units of the southern complex are persuasive arguments for a Precambrian W age for the complex. This view is supported by radiometric ages from Woolsey (1971) who reported a whole-rock $\mathrm{Rb}-\mathrm{Sr}$ age of $2,494 \pm 179 \mathrm{~m} . \mathrm{y}$. for 10 samples of granitic rocks from in or near our map area. Although this age is very slightly younger than the 2.5-b.y. dividing line between Precambrian $W$ and $X$ time, we feel that a Precambrian $W$ age for the rocks is justified. On an isochron plot, Woolsey's data show excessive scatter, beyond experimental error, and the initial $\mathrm{Sr}^{87} / \mathrm{Sr}^{86}$ ratio of 0.7097 is unusually high for granitic rocks of this age. Minerals from these rocks give much younger ages of 1,620 to 1,760 m.y., indicating a strong thermal event at this time. Some opensystem behavior of the total rock systems during this younger event could well have lowered the primary isochron age, as suggested by the scatter and initial ratio, and it is very likely that the granitic rocks are 2,500 m.y. old or older (Precambrian W).

In areas about 30 miles to the south, Aldrich, Davis, and James (1965) dated similar, and probably in part correlative, rocks at 2,700 m.y. We consider that the Precambrian W age for all major units in the southern complex in our map area is now established beyond reasonable doubt.

The absolute time difference between the Bell Creek and Compeau Creek Gneiss is unknown. The 2,494-m.y. isochron (Woolsey, 1971) was derived using samples from both Bell Creek and Compeau Creek Gneisses. The Bell Creek Gneiss appears to have been isotopically homogeneous at the time of Compeau Creek emplacement, but this does not preclude the possibility that it is an older rock whose age was reset by thermal activity related to the Compeau Creek Gneiss.

\section{ORIGIN}

Bell Creek Gneiss.-The origin of the Bell Creek Gneiss is obscured by later metamorphism and deformation. Precambrian W metamorphism attained at least upper amphibolite facies, and Penokean metamorphism ranged from biotite to sillimanite grade in this area. At some places the parent material for the present rock units seems well established. The metamorphosed iron-formations are almost certainly reconstituted iron-rich precipitates of subaqueous origin. The mafic gneiss units with which they are invariably associated are, by implication, also of subaqueous origin. These units together are believed to be remnants of a Precambrian $W$ greenstone terrane.

The origin of Bell Creek granitic gneiss presents a major problem. The clustering of modal compositions near a likely cotectic minimum, as shown in figure 5, suggests an igneous origin. These rocks are not easily interpreted as intrusive rocks, 
however, because they do not appear to intrude any of the units with which they are in contact. In spite of being complexly interlayered with mafic gneiss and other rock types in some areas, the granitic gneiss nowhere clearly truncates or breaches other units and contains no rock bodies which can be clearly assigned a xenolithic origin. The origin is largely an open question, but structural relationships indicate that an origin other than an intrusive igneous rock must be given serious consideration.

Compeau Creek Gneiss.-Gair and Thaden (1968) expressed little doubt that the granitic parts of the Compeau Creek Gneiss are of magmatic origin. Our work supports their findings. The complex and widespread intrusion of the granitic rocks into older rocks of the Bell Creek Gneiss, local feldspathization of older rocks near contacts with Compeau Creek granitic gneiss, and widespread pegmatitic phases in the granitic rocks all suggest a magmatic origin.

Figure 5 shows an interesting variation in modal compositions between massive and gneissic granitic rocks. Although a distinction based on the presence or lack of gneissic structure is not necessarily significant in terms of magmatic evolution, the differences shown in figure 5 suggest that the two are at least in part related in the Compeau Creek Gneiss. We suggest that the gneissic rocks, which tend to be sodic, may be the residue of partially melted sedimentary rocks whose initial composition was more sodic than the composition of the cotectic minimum in the quartz-albite-orthoclase system. The partial melting of such rocks would produce a magma more potassic than the original bulk composition, and a crystalline residue, now preserved as the gneissic rocks, which would become progressively more sodic as melting progressed. The massive rocks, which tend to be potassic, may be the crystallization products of the anatectic magma. This mechanism alone does not explain the highly potassic compositions of some of the massive rocks, but these compositions may be the result of fractional crystallization.

The origin of the schlieren and amphibolitic septa is open to question. Some amphibolite units seem to be clearly xenoliths of Bell Creek mafic gneiss. Others, that bear less resemblance to Bell Creek mafic gneiss, may be more highly altered Bell Creek Gneiss or remnants of some other unknown mafic rock. Many xenoliths are well banded, and their composition sug. gests a sedimentary origin. At one place in the Ishpeming quadrangle, a conglomerate layer a little more than an inch thick occurs in granitic gneiss; the layer contains abundant quartz clasts and a few pebbles, as much as 1 inch in diameter, of quartzite and ferruginous quartzite.

\section{REFERENCES CITED}

Aldrich, L. T., Davis, G. L., and James, H. L., 1965, Ages of minerals from metamorphic and igneous rocks near Iron Mountain, Michigan: Jour. Petrology, v. 6, pt. 3, p. 445-472.

Case, J. E., and Gair, J. E., 1965, Aeromagnetic map of parts of Marquette, Dickinson, Baraga, Alger, and Schoolcraft Counties, Michigan, and its geologic interpretation: U.S. Geol. Survey Geophys. Inv. Map GP-467, 3 sheets.

Dickey, R. M., 1936, The granitic sequence in the southern complex of upper Michigan: Jour. Geology, v. 44, no. 3, p. 317-340.

1938, The Ford River granite of the southern complex of upper Michigan: Jour. Geology, v. 46, no. 3, pt. 1, p. 321-335.

Gair, J. E., 1968, Preliminary geologic map of the Palmer 71/2-minute quadrangle, Marquette County, Michigan: U.S. Geol. Survey openfile map, scale 1:1.2,000.

Gair, J. E., and Thaden, R. E., 1968, Geology of the Marquette and Sands quadrangles, Marquette County, Michigan: U.S. Geol. Survey Prof. Paper 397, $77 \mathrm{p}$.

James, H. L., 1955, Zones of regional metamorphism in the Precambrian of northern Michigan: Geol. Soc. America Bull., v. 66, no. 12 , pt. 1, p. 1455-1488.

1958, Stratigraphy of pre-Keweenawan rocks in parts of northern Michigan: U.S. Geol. Survey Prof. Paper 314-C, p. 27-44.

Lamey, C. A., 1931, Granite intrusions in the Huronian formations of northern Michigan: Jour. Geology, v. 39, no. 3, p. 288-295.

1933, The intrusive relations of the Republic granite: Jour. Geology, v. 41, no. 5, p. 487-500.

1934, Some metamorphic effects of the Republic granite: Jour. Geology, v. 42, no. 3, p. 248-263.

1935, The Palmer gneiss: Geol. Soc. America Bull., v. 46, no. 7, p. $1137-1162$.

Shapiro, Leonard, 1967, Rapid analysis of rocks and minerals by a single-solution method, in Geological Survey Research 1967: U.S. Geol. Survey Prof. Paper 575-B, p. B187-B191.

Snelgrove, A. K. Seaman, W. A., and Ayres, V. L., 1944, Strategic minerals investigations, Marquette and Baraga Counties [Mich.], 1943: Michigan Geol. Survey Prog. Rept. 10,69 p.

Taylor, W. E. G., 1967, The geology of the lower Precambrian rocks of the Champion area of upper Michigan: Northwestern Univ. Rept. 13 (Natl. Aeronautics and Space Admin. Research Grant NGR 14-007-27), 34 p.

Van Hise, C. R., and Bayley, W. S., 1897, The Marquette iron-bearing district of Michigan: U.S. Geol. Survey Mon. 28, $608 \mathrm{p}$.

Woolsey, L. L., 1971, A Rb-Sr geochronological study of the Republic metamorphic node, Republic, Michigan: Lawrence, Univ. Kansas, M.S. thesis.

Zainuddin, S. M., 1971, Petrology of the granitic rocks in the vicinity of Republic Trough in the Upper Peninsula of Michigan: East Lansing, Michigan State Univ. Ph. D. dissert., 76 p. 


\title{
RADIOMETRIC DATING OF INTRUSIVE ROCKS IN THE COTTONWOOD AREA, UTAH
}

\author{
By M. D. CRITTENDEN, JR., J. S. STUCKLESS ${ }^{1}$, R. W. KISTLER; \\ and T. W. STERN, Menlo Park, Calif.; Washington, D.C.
}

\begin{abstract}
Recently completed fission-track and K-Ar dating of zircon, sphene, apatite, muscovite, biotite, and hornblende indicate that the Clayton Peak stock was intruded 37-41 m.y. ago, the Alta stock about 32-33 m.y. ago, and the Little Cottonwood stock between 24 and $31 \mathrm{~m} . \mathrm{y}$. ago. $\mathrm{Pb}-\alpha$ ages on zircon, though showing the same sequence, are about twice as great and are inferred to represent a partial mixing of inherited Precambrian zircons. Acceptance of a middle Tertiary age for the Little Cottonwood stock requires revision of earlier interpretations that it could be as old as Late Cretaceous. K-Ar dates also indicate that the Keetley Volcanics are 32 to $35 \mathrm{~m} . \mathrm{y}$. old, and a single date of $37.3 \mathrm{~m} . \mathrm{y}$. was obtained on the Traverse Volcanics, suggesting that they are more closely related to volcanic activity in the adjoining Oquirrh Mountains.
\end{abstract}

The Cottonwood area is in north-central Utah, about 20 miles airline southeast of Salt Lake City (fig. 1). The area is bounded on the west by the Wasatch fault, a normal fault, which separates it from the Salt Lake Valley. On the east it adjoins the Park City mining district, and the series of igneous rocks considered here extend from one area to the other.

The Cottonwood area lies at the intersection of two of the major tectonic elements of northern Utah (fig. 1), the west-trending Uinta arch (Crittenden, 1964) and the northtrending belt of folds and thrusts of the Sevier orogenic belt (Armstrong, 1968). The interaction of these two elements has long been regarded as significant in localizing the intrusive rocks and the associated ore deposits (Butler and others, 1911; Calkins and Butler, 1943; Tooker, 1971).

The major intrusive bodies of the Cotton wood area comprise three stocks alined in an east-west direction roughly along the Uinta arch; they are, from east to west, the Clayton Peak, Alta, and Little Cottonwood stocks (fig. 1) (Boutwell, 1912; Calkins and Butler, 1943). These bodies form a coherent sequence in both age and composition, being oldest on the east and youngest on the west, and ranging from moderately mafic quartz diorite (Clayton Peak) to quartz monzonite (Little Cottonwood). The central Alta stock intrudes the Clayton Peak, but the Little Cottonwood stock is not in contact with either of the others. All are coarse-grained holocrystalline

\footnotetext{
${ }^{1}$ Present address: Northern Illinois University, DeKalb, III. 60115
}

plutonic rocks. In this respect, they differ markedly from the porphyries of the adjoining Park City district, most of which have an aphanitic or fine- to medium-grained groundmass like those that characterize many other mining districts of western Utah. Recent mapping in the Cottonwood area (Crittenden, 1965; Baker and others, 1966; Bromfield and others, 1970) has shown that each of the western stocks (Alta and Little Cottonwood) contains a younger, porphyritic, and generally more silicic phase (fig. 1). Though each appears to intrude the enclosing nonporphyritic phase, radiometric dating does not reveal a significant difference in age.

\section{RADIOMETRIC DATING}

Attempts to date the intrusive rocks of the Cottonwood area were begun by E. S. Larsen, Jr., of the U.S. Geological Survey, soon after the lead-alpha method was devised, and preliminary results were reported by Crittenden, Sharp, and Calkins (1.952) and by Jaffe and others $(1959$, p. 75$)$. Improvements in the technique for lead analysis (Rose and Stern, 1960, p. 1243) resulted in new determinations on the original samples, and these later measurements (reported here) supersede those by Jaffe. Table 1 summarizes these $\mathrm{Pb}-\alpha$ ages, together with $\mathrm{K}-\mathrm{Ar}$ ages on biotite, muscovite, and hornblende, and recently completed fission-track ages on zircon, sphene, and apatite. Analytical and sample localities are included in tables 2, 3, and 4.

Argon analyses were made using standard isotope dilution techniques (Dalrymple and Lanphere, 1969) and a Nier-type 6 -inch radius, $60^{\circ}$-sector mass spectrometer. The errors shown as plus-or-minus ( \pm ) values range from 2 to 4 percent of the calculated ages and are assigned on the basis of experience with duplicate analyses and uncertainties in individual analyses.

The techniques of fission-track analysis are described by Naeser and McKee (1970) for zircon and apatite and by Stuckless and Sheridan (1971) for sphene. The decay constant used in these calculations was $6.85 \times 10^{-17} \mathrm{yr}^{-1}$. The " \pm " after a determination on a single grain or a population of apatites represents one standard deviation based on the number of 

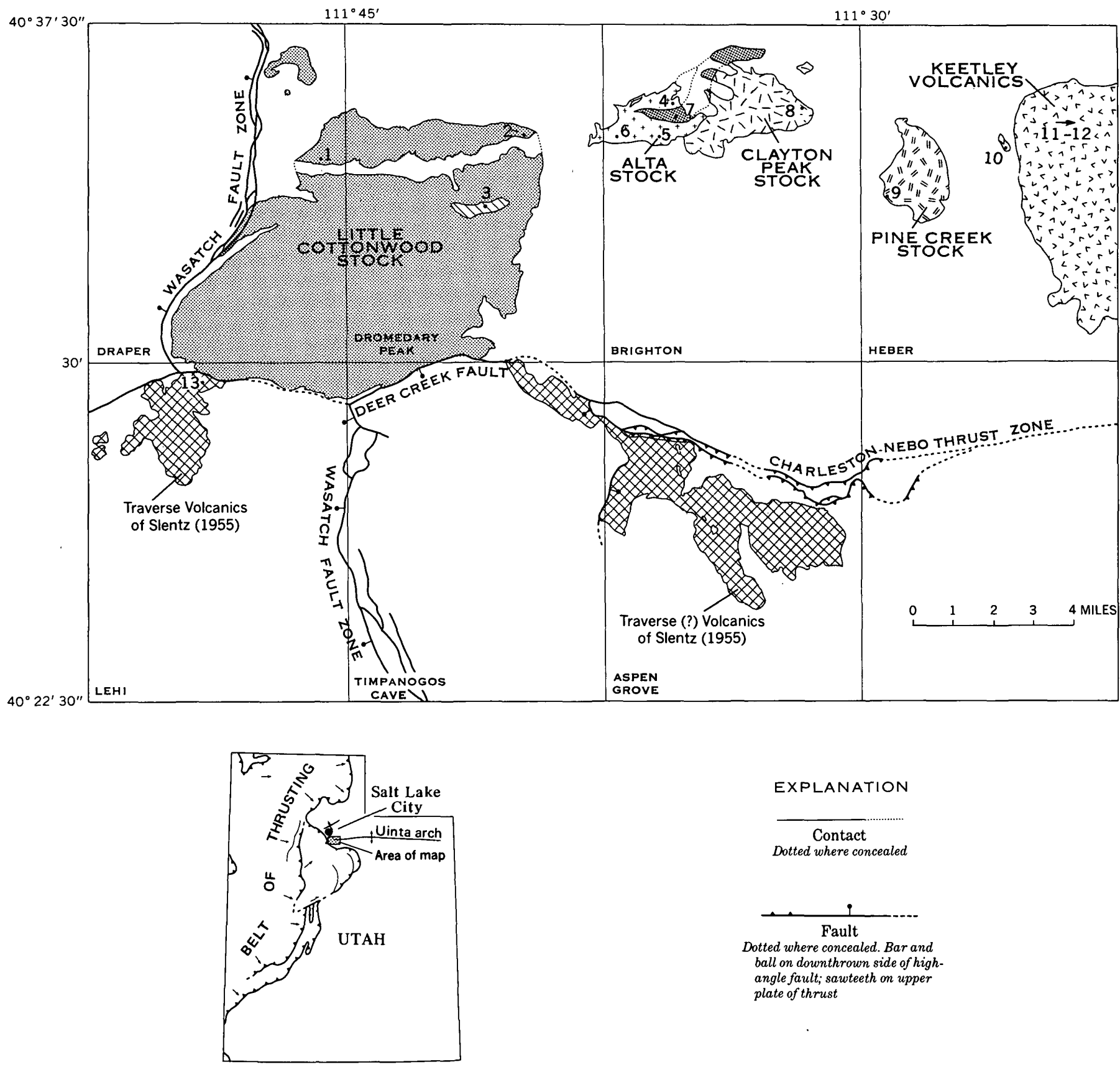

Figure 1.-Map showing regional setting of Cottonwood area, Utah. Numbers refer to sample localities listed in table 1.

fossil, induced, and standard tracks counted. The " \pm " assigned to an average mineral age is twice the standard error of the mean.

\section{INTERPRETATION AND DISCUSSION}

The $\mathrm{Pb}-\alpha$ ages (tables 1 and 2) are consistent with the relative age relations determined from field mapping but (except for thorite from the Clayton Peak stock) are nearly twice as high as the ages obtained by other methods. The close agreement of ages for each intrusive body by the K-Ar dates on muscovite, biotite, and hornblende and by fission-track dates on zircon, sphene, and apatite suggests that the $\mathrm{Pb}-\alpha$ ages do not represent the time of crystallization. This inference is supported also by the $\mathrm{Pb}-\alpha$ ages of 200 to 270 m.y. obtained for the Pine Creek stock (LSH-4 and 4a), whose relations to other porphyritic rocks of the Park City district strongly suggest a Tertiary age.

The zircons in samples LSH-1, 2, and 3 appear almost identical optically, but each sample contains zircons of two 
Table 1.-Summary of radiometric dates, in millions of years

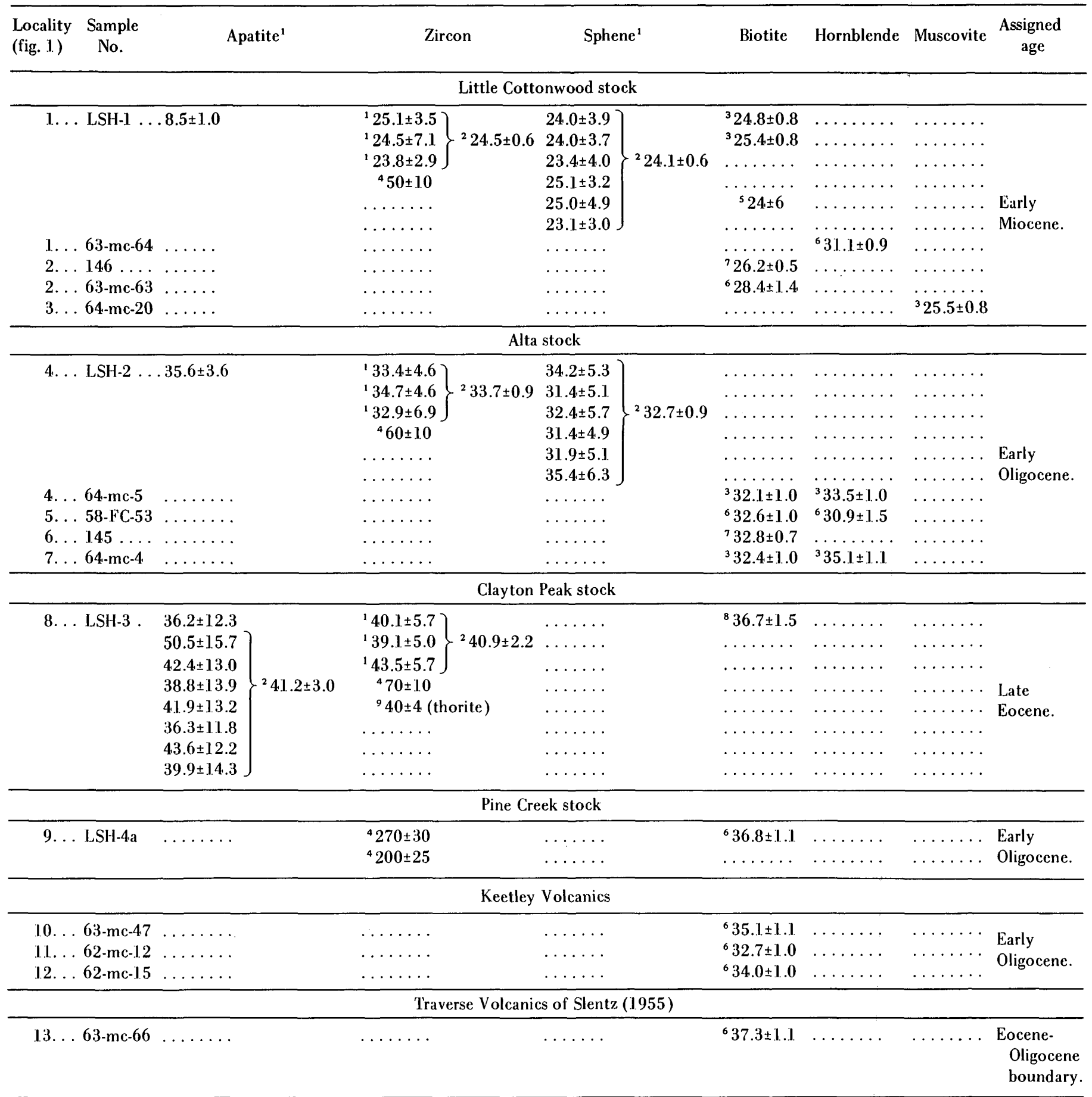

${ }^{1}$ Fission track (J. S. Stuckless, this report).

${ }^{2}$ Average.

${ }^{3} \mathrm{~K}-\operatorname{Ar}$ (J. C. Engels, this report).

${ }^{4} \mathrm{~Pb}-\alpha$ (T. W. Stern, this report).

${ }^{5} \mathrm{Rb}-\mathrm{Sr}$ (Aldrich, 1.961).

distinct shapes. Both kinds are generally euhedral, but in one the $c$ direction is greater than $a$ and $b$, whereas the other form is roughly equidimensional. The proportions of the two forms are different from sample to sample. In LSH-3 the equi-
${ }^{6} \mathrm{~K}-\operatorname{Ar}$ (R. W. Kistler, this report).

${ }^{7} \mathrm{~K}$-Ar (Armstrong, 1963).

${ }^{8} \mathrm{~K}-\mathrm{Ar}$ (J. D. Obradovich, this report).

${ }^{9} \mathrm{~Pb}-\alpha$ (Jaffe and others, 1959).

dimensional form is most abundant; in LSH-2 the elongate form makes up slightly more than half the zircon; in LSH-1. the elongate form strongly predominates. Stern, Phair, and Newell (1971) noted a similar bimodal distribution of zircons 
Table 2.-Lead-alpha analytical data

\begin{tabular}{llccc}
\hline $\begin{array}{l}\text { Sample } \\
\text { No. }\end{array}$ & Mineral & $\alpha /$ mg-hr & $\begin{array}{c}\text { Lead } \\
(\mathrm{ppm})\end{array}$ & $\begin{array}{c}\text { Calculated age } \\
\text { (m.y.) }\end{array}$ \\
\hline LSH-1 . . . . & Zircon & 517 & ${ }^{2} 10.2$ & $50 \pm 10$ \\
LSH-2 . . . . . . do. . & 308 & ${ }^{2} 6.9$ & $60 \pm 10$ \\
LSH-3 . . . . . do. . & 218 & ${ }^{2} 6.0$ & $70 \pm 10$ \\
LSH-3 . . . & Thorite & 5,795 & 115 & 40 \\
LSH-4 . . . & Zircon & 120 & ${ }^{2} 13.3$ & $270 \pm 30$ \\
LSH-4a . . . . . do. & 126 & ${ }^{2} 10.0$ & $200 \pm 25$
\end{tabular}

${ }^{1}$ The lead-alpha age was calculated from the following equations:

$$
t=\mathrm{C} \mathrm{Pb} / \alpha,
$$

where $t$ is the calculated age in millions of years, $\mathrm{C}$ is a constant based upon the $\mathrm{U} / \mathrm{Th}$ ratio, $\mathrm{Pb}$ is the lead content in parts per million, and $\alpha$ is the alpha counts per milligram per hour.

$$
T=t-1 / 2 k t^{2},
$$

where $T$ is the age in millions of years corrected for decay of uranium and thorium, and $k$ is a decay constant based upon the $\mathrm{U} / \mathrm{Th}$ ratio. These constants were used for zircon:

\section{Assumed Th/U ratio}

1.0

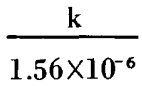

Age is rounded off to nearest $10 \mathrm{~m} . \mathrm{y}$. The error quoted here is that resulting only from uncertainties in analytical techniques.

${ }^{2}$ Lead determinations by Charles Annell and Harold Westley. All values are average of duplicate determinations.

${ }^{3} \mathrm{Jaffe}$ and others (1959).

Table 3.-Potassium-argon analy tical data

[ $\mathrm{K}$ determinations by H. C. Whitehead and L. B. Schlocker, using flame photometry and a lithium internal standard. Constants used for $\mathrm{K}^{40}$ are $\lambda_{\epsilon}=0.585 \times 10^{-10} \mathrm{yr}^{-1}$, $\lambda_{\beta}=4.72 \times 10^{-10} \mathrm{yr}^{-1}$, and atomic abundance of

\begin{tabular}{|c|c|c|c|c|c|}
\hline \multirow{2}{*}{$\begin{array}{l}\text { Sample } \\
\text { No. }\end{array}$} & \multirow{2}{*}{ Mineral } & \multirow{2}{*}{$\begin{array}{c}\mathrm{K}_{2} \mathrm{O} \\
\text { (percent) }\end{array}$} & \multirow{2}{*}{$\begin{array}{l}\mathrm{Ar}^{40} \mathrm{rad} \\
(\text { moles/g) }\end{array}$} & \multirow{2}{*}{$\frac{\mathrm{Ar}^{40} \mathrm{rad}}{\mathrm{Ar}^{40} \text { total }}$} & \multirow{2}{*}{$\begin{array}{c}\text { Age } \\
\text { (m.y.) }\end{array}$} \\
\hline & & & & & \\
\hline \multirow[t]{2}{*}{ LSH-1. } & Biotite & 6.96 & $2.570 \times 10^{-10}$ & 0.73 & 24. \\
\hline & ..ddo. & & $2.629 \times 10^{-10}$ & .87 & \\
\hline $3-\mathrm{m}$ & Hornblende & .961 & $4.448 \times 10^{-11}$ & .62 & \\
\hline & & 9.01 & & .54 & \\
\hline 64-n & Muse & 10.24 & $3.880 \times 10^{-10}$ & .78 & 0.8 \\
\hline \multirow[t]{2}{*}{ 64-mc-5 } & Biotite & 9.15 & $4.376 \times 10^{-10}$ & .47 & \\
\hline & Hornl & .531 & $2.650 \times 10^{-11}$ & .53 & \\
\hline \multirow[t]{2}{*}{ 58-FC-53 } & Biotite & 8.54 & $10^{-10}$ & .70 & \pm 1.0 \\
\hline & Hornble & .55 & 2.55 & .27 & \\
\hline \multirow[t]{2}{*}{ 64-mc-4 } & Biotite & 8.59 & 4.14 & .88 & $32.4 \pm 1.0$ \\
\hline & Horn & .487 & & .47 & 1.1 \\
\hline $\mathrm{SH}$ & Biotite & 8.13 & $10^{-10}$ & .90 & $36.7 \pm 1.5$ \\
\hline LSH-4a . & . . do. . & 5.01 & $0^{-10}$ & .73 & $36.8 \pm 1.1$ \\
\hline 63-mc-47 & ..do. & 7.81 & $4.079 \times 10^{-10}$ & .85 & $35.1 \pm 1.1$ \\
\hline $62-\mathrm{mc}-12$ & . .do. . . & 7.92 & $3.847 \times 10^{-10}$ & .86 & $32.7 \pm 1.0$ \\
\hline $62-m c-15$ & . . do. . . & 7.48 & $3.791 \times 10^{-10}$ & .77 & $34.0 \pm 1.0$ \\
\hline $63-m c-66$ & . do & 5.85 & $3.262 \times 10^{-10}$ & .89 & $37.3 \pm 1.1$ \\
\hline
\end{tabular}
$\left.\mathrm{K}^{40}=1.19 \times 10^{-4} \mathrm{moles} / \mathrm{mole}\right]$

\begin{tabular}{|c|c|c|c|}
\hline \multirow[b]{2}{*}{$\begin{array}{l}\text { Locality No. } \\
\text { (fig. 1) }\end{array}$} & \multirow[b]{2}{*}{ Sample No. } & \multicolumn{2}{|r|}{ Location } \\
\hline & & $\begin{array}{l}\text { Lat (N.) } \\
\text { Long (W.) }\end{array}$ & Specific \\
\hline & $\begin{array}{l}\text { LSH-1 and } \\
63-\mathrm{mc}-64 .\end{array}$ & $\begin{array}{r}40^{\circ} 34^{\prime} 22.8^{\prime \prime} \\
111^{\circ} 45^{\prime} 15.6^{\prime \prime}\end{array}$ & $\begin{array}{l}\text { Temple quarry, near } \\
\text { mouth of Little Cotton- } \\
\text { wood Canyon. }\end{array}$ \\
\hline 2 & $\begin{array}{l}146 \text { and } \\
63-\mathrm{mc}-63 .\end{array}$ & $\begin{array}{l}40^{\circ} 35^{\prime} 0^{\prime \prime} \\
111^{\circ} 39^{\prime} 30^{\prime \prime}\end{array}$ & $\begin{array}{l}1 \frac{1}{2} \text { miles WSW of Alta, } \\
\text { Little Cottonwood Can- } \\
\text { yon. }\end{array}$ \\
\hline 3 . & $64-m c-20 \ldots$ & $\begin{array}{r}40^{\circ} 3 \\
111^{\circ} 4\end{array}$ & White Pine Canyon. \\
\hline 4 & LSH-2. . & $\begin{array}{r}40^{\circ} \\
111^{\circ}\end{array}$ & $\begin{array}{l}\text { Brighton area, Big Cotton- } \\
\text { wood Canyon. Freshly } \\
\text { blasted glacial erratic, } \\
\text { nonporphyritic phase. }\end{array}$ \\
\hline 4 & 64-mc-5 .. & $\begin{array}{r}40^{\circ} \\
111^{\circ}\end{array}$ & $\begin{array}{l}\text { Outcrops just north of line } \\
\text { of Mount Millicent ski } \\
\text { lift, nonporphyritic } \\
\text { phase. }\end{array}$ \\
\hline 5 & 58 - & $\begin{array}{r}40^{\circ} \\
111^{\circ}\end{array}$ & $\begin{array}{l}\text { Outcrops west of Lake } \\
\text { Catherine, nonporphy- } \\
\text { ritic phase. }\end{array}$ \\
\hline 6 & $145 \ldots$ & $\begin{array}{r}40^{\circ} \\
111^{\circ}\end{array}$ & $\begin{array}{l}1 \text { mile SE of Alta, Little } \\
\text { Cottonwood Canyon, } \\
\text { nonporphyritic phase. }\end{array}$ \\
\hline 7 & $64-m c-4 \ldots$ & $\begin{array}{r}40^{\circ} 35 \\
111^{\circ} 35\end{array}$ & $\begin{array}{l}\text { Small quarry immediately } \\
\text { south of Lake Mary dam, } \\
\text { porphyritic phase. }\end{array}$ \\
\hline 8 & LSH-3 . . & $\begin{array}{r}40^{\circ} 36^{\prime} 03^{\prime \prime} \\
111^{\circ} 32^{\prime} 24^{\prime \prime}\end{array}$ & $\begin{array}{l}\text { Southwest edge of Lake } \\
\text { Brimhall, head of Pine } \\
\text { Creek, Brighton quadran- } \\
\text { gle. }\end{array}$ \\
\hline 9 & LSH-4a .. & $\begin{array}{r}40^{\circ} 3 \\
111^{\circ} 2\end{array}$ & $\begin{array}{l}\text { Quarry beside road in Pine } \\
\text { Creek Canyon, Heber } \\
\text { quadrangle. }\end{array}$ \\
\hline 10 & $63-\mathrm{mc}-47$ & $\begin{array}{r}40^{\circ} 34^{\prime} \\
111^{\circ} 25^{\prime}\end{array}$ & $\begin{array}{l}\text { Quarry west of Provo River } \\
\text { at mouth of Cottonwood } \\
\text { Canyon. }\end{array}$ \\
\hline & & $\begin{array}{r}40^{\circ} 36^{\prime} 17^{\prime \prime} \\
111^{\circ} 17^{\prime} 45^{\prime \prime}\end{array}$ & $\begin{array}{l}\text { Quarry on point of ridge } \\
0.9 \text { mile WSW of Francis. }\end{array}$ \\
\hline 12 & $62-\mathrm{mc}-15$. & $\begin{array}{r}40^{\circ} 28^{\prime} 0^{\prime \prime} \\
111^{\circ} 3^{\prime} 30^{\prime \prime}\end{array}$ & $\begin{array}{l}\text { Cliffs overlooking Leon- } \\
\text { ards Lake. }\end{array}$ \\
\hline 13 & 63-mc-66. . & $\begin{array}{r}40^{\circ} 29^{\prime} 38^{\prime \prime} \\
111^{\circ} 49^{\prime} 30^{\prime \prime}\end{array}$ & $\begin{array}{l}\text { Roadcuts on north slope of } \\
\text { Traverse Range. }\end{array}$ \\
\hline
\end{tabular}

Table 4.-Sample locality data

in the Boulder Creek batholith, Colorado, and concluded that the anhedral zircons with lower length to width ratios were inherited by assimilation from older rocks. Although the equidimensional zircons in the Cottonwood area are not anhedral, it is possible that some of them may be inherited.

That a large proportion of zircons is inherited is the most reasonable way to account for the anomalously high $\mathrm{Pb}-\alpha$ ages of samples LSH-4 and 4a and is inferred to contribute to the other dates also. It seems probable that the inherited zircons were heated sufficiently by the magma to anneal their inherited fission tracks and to remove any radiation damage which might be used to distinguish them optically but not sufficiently to bring their lead-uranium content into equili- 
brium. Hence the fission-track age gives the age of crystallization, whereas the $\mathrm{Pb}-\alpha$ ages still bear the partial imprint of the previous history of these rocks.

Two other explanations for the older $\mathrm{Pb}-\alpha$ ages that cannot be excluded are the presence of nonradiogenic lead in the concentrates and systematically high lead values. The majority of the zircon concentrates contain less than $10 \mathrm{ppm} \mathrm{Pb}$, and it is possible that the errors exceed the 5 percent commonly assumed for isotope dilution and chemical values determined for zircon of higher lead content. If so, however, one would not expect to find ages so systematically related to those determined by two other age techniques.

The Clayton Peak stock is regarded as having been emplaced between 37 and 41 m.y. ago (late Eocene). The relatively large statistical uncertainties in dates for the apatite grains result from the small number of fossil fission tracks counted. Nevertheless, the agreement between the average of these results and those from zircon suggests relatively rapid cooling and absence of later thermal events (Naeser and others, 1971).

The Alta stock yields a strikingly concordant array of ages, indicating that it was intruded between 32 and 33 m.y. ago (early Oligocene). Ages on different minerals by different methods on both the nonporphyritic and younger porphyritic phases agree within the limits of analytical error. The concordance of the apatite fission-track age with those for zircon and sphene suggests relatively rapid cooling and the absence of later thermal events.

The Little Cottonwood stock yields ages with the largest spread and involves structural complications that have led to speculation that it could be as old as Cretaceous (Baker and Crittenden, 1961). This interpretation depends on field relations which show that the stock is bounded on the south and west by rocks of the upper plate of the Charleston-Nebo thrust. To the southeast the thrust is overlapped by latest Cretaceous and Paleocene rocks, which places a minimum age of Cretaceous on the thrust. The rocks of the upper plate are separated from the Little Cottonwood stock and its contact metamorphic aureole by many tens of feet of dense mylonite. The mylonite was believed to have been developed by the Charleston-Nebo thrust, thereby requiring the stock to be older than the thrust.

If the Cretaceous age were accepted, the numerous radiometric dates around $25 \mathrm{~m} . \mathrm{y}$. would have to be explained by a thermal resetting of the mineral ages. Regional heating, centered west of the area shown in figure 1, could accomplish this resetting and still leave the proper relative ages for the various intrusives since the ages increase eastward, but there is no independent evidence for such a heat source. Furthermore, the temperature required to completely reset zircon during a period of $1 \mathrm{~m} . \mathrm{y}$. is $450^{\circ}$ to $600^{\circ} \mathrm{C}$ (Naeser and others, 1971). In order for apatite in the nearby Alta stock to retain all its lission tracks and therefore to yield an age concordant with zircon, it could not have been heated above $75^{\circ} \mathrm{C}$ for more than 1 m.y. (Naeser and Faul, 1969). Such a steep thermal gradient on a regional scale seems unreasonable. Thus the concordant sphene and zircon fission-track and the nearly concordant K-Ar dates coupled with the possible explanation for the older $\mathrm{Pb}-\alpha$ dates suggest that the earlier Cretaceous age assignment for the Little Cottonwood stock is not correct.

The above argument supports an alternate age assignment for the mylonite. Crittenden, Sharp, and Calkins (1.952, p. 30) and Armstrong $(1963$, p. 168$)$ proposed that the mylonite might be the product of movement along the Deer Creek fault, a normal fault with unknown but large middle Tertiary displacement. In addition to the stock, this fault cuts volcanic and clastic sediments of the Tibble Formation (Baker and Crittenden, 1961). These sediments are assigned to the Tertiary and are believed to be closely related in origin to the volcanic rocks of the Traverse Range, which have yielded a K-Ar date of $37 \mathrm{~m} . \mathrm{y}$.

The present data suggest that the Little Cottonwood stock was intruded between 24 and $31 \mathrm{~m} . y$. ago. The two biotite ages from the eastern margin of the stock are significantly older than most of the ages from Temple quarry (loc. 1, fig. 1) near the western edge. That these older ages may more nearly represent the time of intrusion than do the more abundant 24 . to 25-m.y. ages is suggested by the discordance of both the one hornblende age and the younger apatite ages. The 8.5-m.y. date for the apatite clearly indicates a thermal resetting. Higher temperatures are required to reset hornblende $\left(650^{\circ} \mathrm{C}\right)$ than are required for biotite $\left(325^{\circ} \mathrm{C}\right.$ ) (Evernden and Kistler, 1970), and it seems possible that near the Temple quarry, temperatures were reached that affected all the mineral ages, except that of the K-Ar in hornblende.

The coincidence of the 24- to 25-m.y. ages with that obtained for the muscovite from the greisen in White Pine Canyon (loc. 3) suggests that this hydrothermal mineralization may have accompanied local heating in the western part of the stock. Alternatively, the proposed regional heating may not have been great enough to affect any minerals except apatite. If so, the older hornblende age may be the result of incorporated material that was not completely outgassed or of extraneous argon which would affect the age of the lowpotassium phase (hornblende) more than the higher potassium mineral (biotite).

The 8.5-m.y. age on the apatite from LSH-I cannot be interpreted directly because the rate of annealing is dependent on both time and temperature. Thus the age may represent either the end of complete annealing at $8.5 \mathrm{~m} . \mathrm{y}$. or an averaging by partial annealing of an earlier and a later episode. It is most reasonable to infer that the 8.5-m.y. date represents the approximate time of cooling through the $100^{\circ} \mathrm{C}$ isotherm. Assuming typical geothermal gradients, this cooling might be accounted for by an uplift of about $3 \mathrm{~km}(10,000 \mathrm{feet})$ and subsequent denudation on the order of 6 to $10 \mathrm{~m} . \mathrm{y}$. ago, implying an episode of rapid uplift on the Wasatch fault in the early Pliocene. 


\section{REGIONAL RELATIONS}

The chronology of igneous activity in the Cottonwood and Park City district, reported here, and in the Bingham district of the Oquirrh Mountains to the west (Moore and Lanphere, 1971) is summarized in figure 2. Although the data from Park City are limited, it appears that intrusive activity began in all three areas at about the same time in the late Eocene to early Oligocene (37-41 m.y. ago). Volcanism in and east of the Park City district continued until 32-34 m.y. ago, according to dates on the Keetley Volcanics. Geologic relations near Keetley show that the volcanic rocks are intruded by shallow stocks and locally are mineralized (Bromfield and others, 1970; Bromfield and Crittenden, 1971), suggesting that ore deposition also took place during this interval. At Bingham, mineralization ended before $35 \mathrm{~m} . \mathrm{y}$. ago. In the Cottonwood area, plutonism and associated greisen mineralization apparently continued about $10 \mathrm{~m} . \mathrm{y}$. longer, until very late in Oligocene time. If volcanic activity accompanied the Cottonwood intrusions, any record of it has been erased by uplift and erosion. Hypabyssal dikes ranging from lamprophyres to rhyolites are widespread in the Cottonwood area (Calkins and Butler, 1943) but do not seem abundant enough to represent the roots of a volcano.

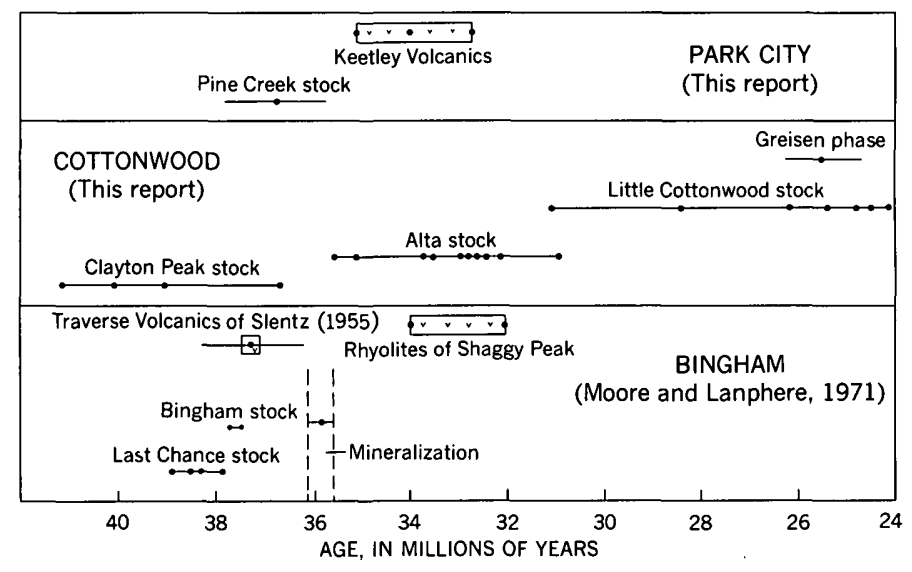

Figure 2.-Radiometric dates from Park City, Cottonwood, and Bingham areas, Utah.

\section{REFERENCES CITED}

Aldrich, L. T., 1961, Discussion in Kulp, J. L., ed., Geochronology of rock systems: New York Acad. Sci. Annals, v. 91, p. 463.

Armstrong, R. L., 1963, Geochronology and geology of the eastern Great Basin in Nevada and Utah: New Haven, Conn., Yale Univ., unpub. Ph. D. thesis, $202 \mathrm{p}$.

-1968, Sevier orogenic belt in Nevada and Utah: Geol. Soc. America Bull., v. 79, p. 429-458.

- 1970, K-Ar dating using neutron activation for $\mathrm{Ar}$ analysis: Comparison with isotope dilution $\mathrm{Ar}$ analyses: Geochim. et Cosmochim. Acta, v. 34, p. 233-236.

Baker, A. A., Calkins, F. C., Crittenden, M. D., Jr., and Bromfield,
C. S., 1966, Geologic map of the Brighton quadrangle, Utah: U.S Geol. Survey Geol. Quad. Map GQ-534, scale 1:24,000.

Baker, A. A., and Crittenden, M. D., Jr., 1961, Geology of the Timpanogos Cave quadrangle, Utah: U.S. Geol. Survey Geol. Quad. Map GQ-132, scale $1: 24,000$.

Boutwell, J.M., 1912, Geology and ore deposits of the Park City district, Utah: U.S. Geol. Survey Prof. Paper 77, 231 p.

Bromfield, C. S., Baker, A. A., and Crittenden, M. D., Jr., 1970, Geologic map of the Heber quadrangle: U.S. Geol. Survey Geol. Quad. Map GQ-864, scale 1:24,000.

Bromfield, C. S., and Crittenden, M. D., Jr., 1971, Geologic map of the Park City East quadrangle: U.S. Geol. Survey Geol. Quad. Map GQ-852, scale $1: 24,000$.

Butler, B. S., Loughlin, G. F., Heikes, V. C., and others, 1911, Ore deposits of Utah: U.S. Geol. Survey Prof. Paper 111, 672 p.

Calkins, F. C., and Butler, B. S., 1943, Geology and ore deposits of the Cottonwood-American Fork area, Utah: U.S. Geol. Survey Prof Paper 201, $152 \mathrm{p}$.

Crittenden, M. D., Jr., 1964, General geology of Salt Lake County, Sec. 1 in Geology of Salt Lake County: Utah Geol. and Mineralog. Survey Bull. 69, p. 11-48.

1965, Geology of the Draper, Dromedary Peak, Mount Aire, and Sugar House quadrangles, Utah: U.S. Geol. Survey Geol. Quad. Maps GQ-377, GQ-378, GQ-389, and GQ-380, scale $1: 24,000$.

Crittenden, M. D., Jr., Sharp, B. J., and Calkins, F. C., 1952, Geology of the Wasatch Mountains east of Salt Lake City, Parleys Canyon, and Traverse Range: Utah Geol. Soc., Guidebook to the geology of Utah, no. 8, p. 1-37.

Dalrymple, G. B., and Lanphere, M. A., 1969, Potassium-argon dating: principles, techniques, and applications to geochronology: San Francisco, W. H. Freeman and Co., 258 p.

Evernden, J. F., and Kistler, R. W., 1970, Chronology of emplacement of Mesozoic batholithic complexes in California and western Nevada: U.S. Geol. Survey Prof. Paper 623, 42 p.

Jaffe, H. W., Gottfried, David, Waring, C. L., and Worthing, H. W., 1959, Lead-alpha age determinations of accessory minerals of igneous rocks (1953-1957): U.S. Geol. Survey Bull. 1097-B, p. $65-148$.

Moore, W. J., and Lanphere, M. A., 1971, The age of porphyry-type copper mineralization in the Bingham district, Utah-A refined estimate: Econ. Geology, v. 66, p. 331-334.

Naeser, C. W., and Faul, H. O., 1969, Fission track annealing in apatite and sphene: Jour. Geophys. Research, v. 74, p. 705-710.

Naeser, C. W., Kistler, R. W., and Dodge, F. C. W., 1971, Ages of coexisting minerals from heat-flow borehole sites, central Sierra Nevada batholith: Jour. Geophys. Research, v. 76, p. 6462-6463.

Naeser, C. W., and McKee, E. H., 1970, Fission-track and K-Ar ages of Tertiary ash-flow tuffs, north-central Nevada: Geol. Soc. America Bull., v. 81, p. 3375-3384.

Rose, H. J., Jr., and Stern, T. W., 1960, Spectrochemical determination of lead in zircon for lead-alpha age measurements: Am. Mineralogist, v. 45, p. 1243-1256.

Slentz, L. W., 1955, Salt Lake group in lower Jordan Valley, Utah: Utah Geol. Soc., Guidebook to the geology of Utah, no. 10, p. 23-36.

Stern, T. W., Phair, George, and Newell, M. F., 1971, Boulder Creek batholith-Part II, Isotopic age of emplacement and morphology of zircon: Geol. Soc. America Bull., v. 82, p. 1615-1634.

Stuckless, J. S., and Sheridan, M. F., 1971, Tertiary volcanic stratigraphy in the Goldfield and Superstition Mountains, Arizona: Geol. Soc. America Bull., v. 82, p. 3235-3240.

Tooker, E. W., 1971, Regional structural controls of the deposits, Bingham mining district, Utah, U.S.A.: Japan Geol. Soc., Spec. Issue 3, p. 76-81 [Internat. Mineralog. Assoc.-Internat. Assoc. Genesis of Ore Deposits Mtgs. Proc.] 


\title{
MAGNETIZATIONS OF SOME LATE CRETACEOUS GLASSY TUFFS, VOLCANIC BRECCIAS, AND ALTERED BASALTS OF THE ELKHORN MOUNTAINS VOLCANIC FIELD, WESTERN MONTANA
}

\author{
By W. F. HANNA, Menlo Park, Calif.
}

\begin{abstract}
New magnetization data for Late Cretaceous glassy welded tuffs, volcanic breccias, and altered basalts from the Elkhorn Mountains volcanic field, together with geologic, mineralogic, and K-Ar data, indicate that (1) the glassy tuffs have unusually strong, uniform remanent magnetizations which are reversely polarized, much of the remanence perhaps residing in submicroscopic single-domain iron oxide particles within the glass itself, (2) breccias emplaced at minimum temperatures of about $400^{\circ} \mathrm{C}$ have moderately dispersed remanent magnetization directions which are normally polarized, and (3) basalts that occur within a broad area of hydrothermal alteration have remanent magnetization directions which are normally, horizontally, and reversely polarized. Present and previous studies indicate the occurrence of from two to eight complete field reversal cycles during emplacement of the volcanic field about $78 \mathrm{~m}$.y. ago. Among the rocks studied, only basalt from the Zosell mining district is important as a major aeromagnetic anomaly source.
\end{abstract}

After original paleomagnetic studies on the Elkhorn Mountains Volcanics (Colville, 1961; Hanna, 1965, 1967) were completed, two pieces of new information about the volcanic field that offered an opportunity to further the paleomagnetic understanding of the rocks were published. First, radiometric dates obtained for welded tuffs and breccias not previously sampled (Robinson and Marvin, 1967; Robinson and others, 1968) provided a firm time base for previous inferences about paleomagnetic field directions and polarities. Second, an aeromagnetic map covering parts of the Elkhorn Mountains volcanic field (Johnson and others, 1965) showed an anomalous zone of field values over basalts that occur within or near an extensive mining district, suggesting that the basalts have anomalous magnetizations. In order to update and supplement the previous magnetic work, the dated tuffs and breccias as well as the basalts suspected of having anomalous magnetizations were sampled. Results are treated together here for the purpose of presenting a complete summary of new magnetic data from the Elkhorn Mountains volcanic field.

All three groups of sampled rocks (tuffs, breccias, and basalts) have features that are distinctive from those of rocks previously sampled in the volcanic field. For example, two of the welded tuffs have high glass content and are among the oldest glassy rocks reported in the United States. These glassy tuffs were the first rocks radiometrically dated from the volcanic field. Although the radiometric data are not in perfect harmony with relative ages inferred from observed structural relations and limited paleontological data, they firmly establish the Late Cretaceous age of the rocks. The volcanic breccias, which are lithologically similar to previously sampled breccias in the volcanic field (although it is not possible to infer their temperature of formation from outcrop inspection), were the second rocks radiometrically dated. The dates obtained agree well with relative ages inferred from observed field relations. The basalts are unlike previously sampled rocks from the volcanic field in that they occur within an area subjected to regional hydrothermal alteration which accompanied extensive mineralization. One basalt sample was highly altered, and two others were slightly altered.

\section{MEASUREMENT PROCEDURES}

Magnetic measurements were made with spinner magnetometers of the types described by Doell and Cox (1965a) and Phillips and Kuckes (1967) and a magnetic susceptibility apparatus slightly modified from that described by Hanna (1968a). Oriented samples were collected by portable drill (Doell and Cox, 1965a) or, in areas of rugged terrain, by hand. Remanent magnetization measurements were made by W. E. Huff and Arthur Conradi in U.S. Geological Survey laboratories in Silver Spring, Md., and Menlo Park, Calif.

Selected specimens were partly demagnetized in peak fields of 400 Oe, by use of equipment described by Doell and Cox (1.967a). Thermomagnetic data for 12 specimens, measured in air, were provided by E. A. Mankinen, who used a recording magnetic balance (Doell and Cox, 1967b). Curie temperatures were estimated from plots of magnetization versus temperature in fields of 1,500 to $5,000 \mathrm{Oe}$, with a linear sampling rate of $10^{\circ} \mathrm{C}$ per minute within the temperature interval $30^{\circ}$ to $700^{\circ} \mathrm{C}$.

The spinner magnetometers provided remanent magnetization directions accurate to within about $2^{\circ}$ and magnetization intensities accurate to approximately 5 percent. Susceptibility values are estimated to be accurate to within about 1 or 2 
percent. The accuracy of the temperature calibration for the magnetic balance is approximately $2^{\circ} \mathrm{C}$ (Grommé and others, 1969).

\section{GLASSY WELDED TUFFS}

\section{Occurrence and description}

Two outcrops of Late Cretaceous glassy welded tuff were sampled near Wolf Creek and Three Forks, about $125 \mathrm{~km}$ apart (fig. 1). At each site, stony welded tuffs in stratigraphic contact above and below the glassy rocks were also sampled for comparison.

The welded tuffs near Wolf Creek are exposed in a quarry next to the Great Northern Railway approximately $1.5 \mathrm{~km}$ south of Wolf Creek (lat $46^{\circ} 59.66^{\prime} \mathrm{N}$., long $112^{\circ} 04.40^{\prime} \mathrm{W}$.). They were identified by Adolf Knopf in 1947, were described by Barksdale (1951), and were stratigraphically reassigned from the Adel Mountain Volcanics of Lyons (1944, p. 449 and 459) to the western facies of the Two Medicine Formation (R. G. Schmidt, 1963; written commun., 1968), which is the northern equivalent of the Elkhorn Mountains Volcanics

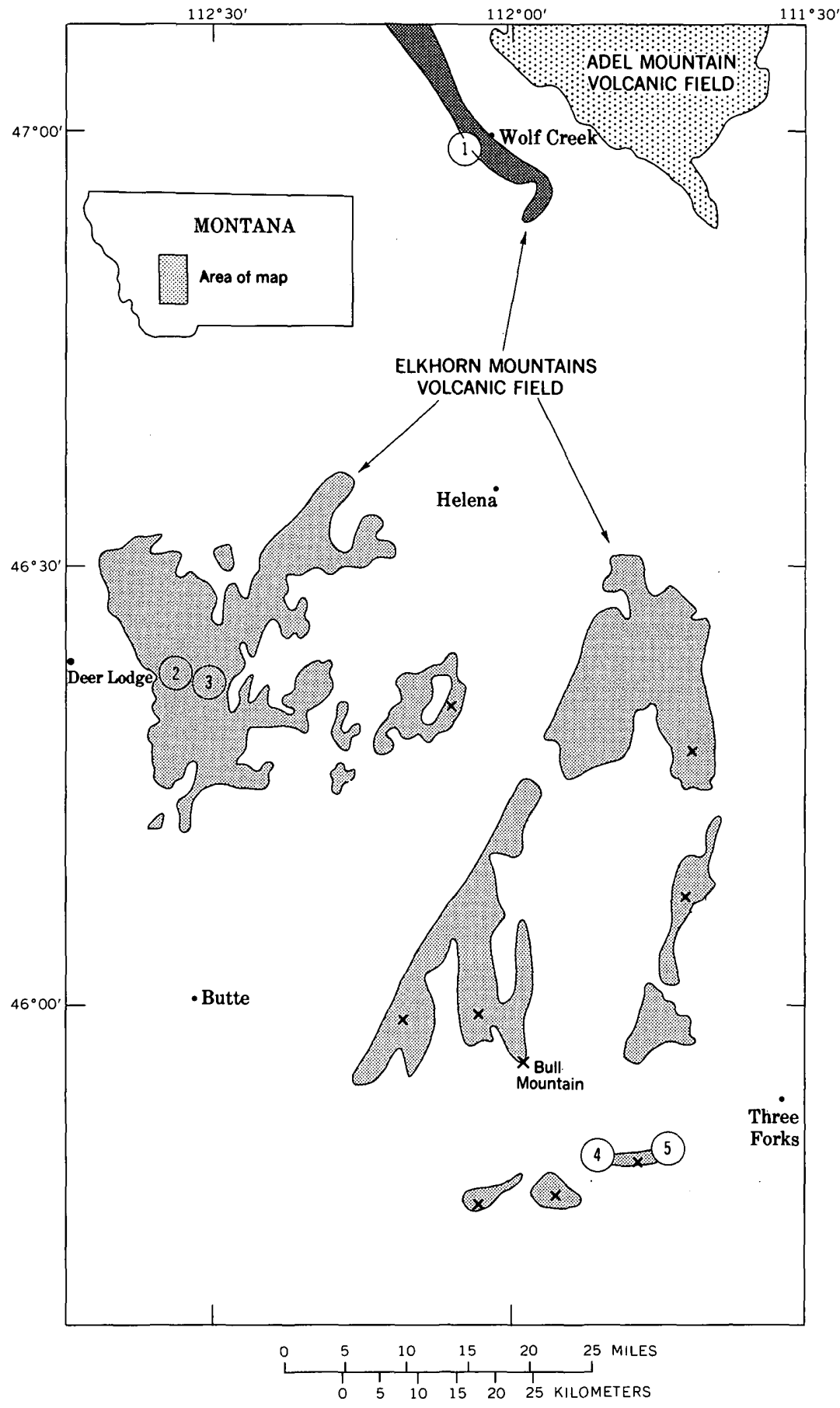

EXPLANATION

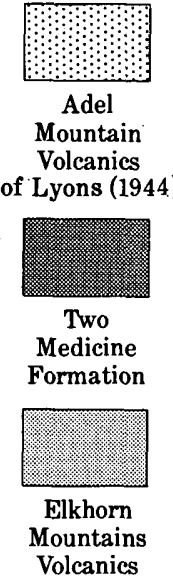

LOCALITIES DESCRIBED IN TEXT

1 Wolf Creek

2 Zosell district

3 Cliff Mountain

4 Jefferson Canyon

5 Three Forks

Locality sampled previously (Hanna, 1967)

Figure 1.-Map showing sampling localities and major remnants of Late Cretaceous volcanic rocks. Distribution of rocks drawn from data of Klepper and others (1957), Smedes (1966), Robinson (1963), Lyons (1944), and Viele and Harris (1965). Rocks near Wolf Creek belong to the Two Medicine Formation and are correlative in part with the Elkhorn Mountains Volcanics (Schmidt, 1963; written commun., 1968). 
(Klepper and Smedes, 1959; Viele and Harris, 1965). Magnetic data here will be compared with other results previously obtained (Hanna 1965, 1967, 1969) within the Elkhorn Mountains volcanic field to the south.

The welded tuffs near Three Forks are exposed in an isolated outcrop $15 \mathrm{~km}$ southwest of Three Forks and $5 \mathrm{~km}$ northeast of Sappington (lat $45^{\circ} 49.85^{\prime} \mathrm{N}$., long $111^{\circ} 43.32$ W.) They were described by G. D. Robinson and H. F. Barnett and were assigned to the Elkhorn Mountains Volcanics (Robinson, 1963, p. 88-89; p. 92-93).

The sampled rocks near Wolf Creek have an average strike of N. $37^{\circ} \mathrm{W}$. and a dip of $26 \%^{\circ} \mathrm{SW}$., whereas those near Three Forks have an average strike of east-west and a dip of $70^{\circ} \mathrm{N}$. Field relations indicate that the Wolf Creek section is right-side-up. However, field evidence at the Three Forks site is insufficient to dismiss the possibility that the section is overturned.

The geologic settings of the Wolf Creek and Three Forks sites are similar insofar as both rock sequences consist largely of devitrified welded tuffs and lava flows at the margin of the Elkhorn Mountains volcanic field, and both are on soles of major thrusts involving Precambrian rocks (Robinson and Marvin, 1967, p. 606). However, detailed petrologic and chemical characteristics of the glassy rocks from the two areas are sharply contrasting.

Petrologically, the glassy rocks near Wolf Creek contain more highly mafic phenocrysts and have a more distinct welded fabric than those near Three Forks. Volume percentages of black iron oxide grains (exceeding $10 \mu \mathrm{m}$ ) also differ somewhat on the basis of thin-section inspection. The upper stony tuff, glassy tuff, and lower stony tuff sequence at Wolf Creek has modal iron oxide contents of 1.0, 1.3, and 0.9 percent, respectively, whereas the analogous sequence at Three Forks contains $0.9,1.1$, and 0.7 percent, respectively. Glassy rocks at each site contain a few iron oxide phenocrysts as much as $0.3-0.6 \mathrm{~mm}$ in diameter.

Chemically, the glassy rocks near Wolf Creek contain less $\mathrm{Fe}_{2} \mathrm{O}_{3}$ and $\mathrm{FeO}$ than those near Three Forks (Knopf, 1957, p. 84; Robinson, 1963, p. 91; Robinson and Marvin, 1967, p.
604). It is of interest that the iron oxide content for the glass alone at the Three Forks site is a high percentage (about 65 to 80 percent) of that for the whole glassy rock at that site. This relation suggests that, if this iron oxide is largely in the form of magnetic particles, much of the magnetization is contained in the glass itself. It is not known whether the same relation between glass and whole rock also obtains at Wolf Creek. ${ }^{1}$

Thermomagnetic curves for the glasses at Wolf Creek and Three Forks (fig. 2), shown with a curve obtained for resampled tuffs of the Elkhorn Mountains Volcanics at Conrow Creek ( $X$ near Bull Mountain, fig. 1), provide further information about iron oxide content. The estimated Curie temperatures of $560^{\circ} \mathrm{C}$ and $575^{\circ} \mathrm{C}$ for the glasses at Wolf Creek and Three Forks are consistent with those for titaniumpoor titanomagnetite (Akimoto and Katsura, 1959, p. 81; Nagata, 1967, p. 502). The curve for the tuff, in contrast, indicates that two kinds of magnetic mineral are present, one having a Curie temperature of $360^{\circ} \mathrm{C}$ and the other, $580^{\circ} \mathrm{C}$. The observed irreversibility of the heating and cooling curves, accompanied by slight decreases in Curie temperatures, may be an expression of a change in the magnetic mineral to a more stable state (Nagata, 1961, p. 96) or to oxidation (Ade-Hall and others, 1965; Wilson and others, 1968; Wasilewski, 1968; Creer and Peterson, 1969; Sanver and O'Reilly, 1969).

Stony tuffs at the sites of glassy rocks have thermomagnetic curves (not shown) similar to those of the glasses, suggesting that nearly pure magnetite is the predominant magnetic constituent throughout the cooling units. There is some possibility that small amounts of minerals of the ilmenitehematite group would go undetected in high-field thermo-

\footnotetext{
${ }^{1}$ It is of further interest that the rocks near Three Forks are unusually high in potassium (Robinson and Marvin, 1967, p. 604). The author's discovery in 1962 of leucite-rich flows (Hanna, 1965, p. 129) in the eastward continuation of the volcanic section from the glassy rock site suggested that this sequence of Elkhorn Mountains Volcanics might be more alkalic than the normally calc-alkalic rocks elsewhere in the volcanic field. The author suggested that these alkalic rocks might be in some way related to similar rocks in the Big Belt, Little Belt, and Highwood Mountains to the northeast.
}
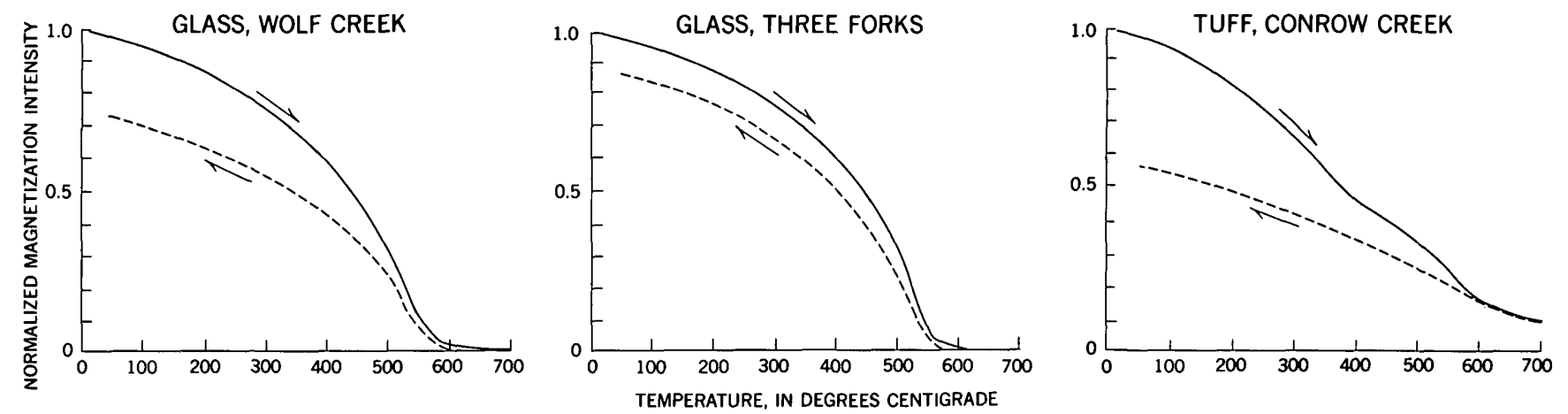

Figure 2.-Thermomagnetic curves for glasses at Wolf Creek and Three Forks and for previously sampled tuff at Conrow Creek. Plots of normalized magnetization intensity versus temperature are for external fields of 2,000 Oe for the glasses and 5,000 Oe for the tuff. Measurements made in air. Solid line represents heating cycle; dashed line, cooling cycle. 
magnetic measurements made in air, as experienced by Uyeda $(1958$, p. 30$)$. However, no ilmenohematite lamellas were observed in spinel-type iron oxide grains, even at highest power settings, under the reflecting microscope.

\section{Age}

A Late Cretaceous age for both sites of glassy rocks is supported by radiometric age data. Robinson and Marvin (1967, p. 605) reported K-Ar dates of $73 \pm 2$ and $72 \pm 7$ m.y. for biotite and plagioclase from glassy rocks $2.2 \mathrm{~km}$ northwest of the sampled quarry near Wolf Creek, and dates of $74 \pm 4$ m.y. for both biotite and plagioclase at the Three Forks site. Robinson and Marvin (1967, p. 607) and Robinson, Klepper, and Obradovich (1968, p. 567-568) further suggested that the glassy tuffs are several million years older than the biotite and plagioclase data indicate, mainly on the basis of more recent radiometric data on hornblende from the Elkhorn Mountains Volcanics (discussed in the section on volcanic breccias in this paper) and on the basis of recent stratigraphic and paleontologic work.

\section{Magnetization}

The most striking magnetic feature of the welded tuff sites is the strong remanent magnetization intensities of the glassy rocks relative to those of their stony equivalents (table 1; fig. 3 ). The glassy rocks, as expected, weigh less than their stratigraphic neighbors, and thus an inverse correlation exists between magnetization intensity and rock density. This inverse correlation is rare for geologic materials; it is usually restricted to large-scale counterparts such as contrasts between fresh and serpentinized ultramafic rocks and contrasts between granitic rocks and metamorphic rocks into which they intrude. Where found on a large enough scale, the inverse density-magnetization contrast can cause a direct association of positive magnetic anomalies (depending upon the magnetization direction) and negative gravity anomalies.

The glassy rocks at Wolf Creek and Three Forks are also characterized by highly uniform or homogeneous remanent magnetizations relative to other rocks of the Elkhorn Mountains Volcanics. This uniformity may reflect a homogeneous assemblage of submicroscopic magnetic oxides within the glass itself. The only rock unit of the Elkhorn Mountains Volcanics having a substantially more uniform remanent magnetization is tuff M of Conrow Creek, discovered by Colville (1961) and extensively resampled and studied by Hanna $(1965,1967$; new data in table 1 of this report), which provided the first reliable Late Cretaceous pole position and evidence for field reversals within the volcanic field.

The Koenigsberger ratios, or $Q$ values (ratios of remanent to induced magnetization intensity), of the glassy tuffs at Wolf Creek and Three Forks are about 15 times and 3 times, respectively, greater than their stony counterparts. The much higher $Q$ value of Wolf Creek glassy tuff (about 64) relative to Three Forks glassy tuff (about 3 ) suggests that the average size of magnetic constituents in Wolf Creek tuff may be smaller than that in Three Forks tuff, a conclusion based on work of others (Nagata, 1961; Parry, 1965) but not obvious from petrographic work.

Remanent magnetizations of the glassy and stony tuffs at each site are reversed (opposite in sense to the present north-seeking pole in Montana). If the in-place pole positions at each site are corrected for structural deformation by rotation about the present strike direction equal to the amount of present dip, the corrected poles fall within the upper southeastern octant (fig. 3) of the projection. This octant contains the reversed pole position previously obtained for the Elkhorn Mountains Volcanics (Hanna, 1967, p. 607).

If we assume that the previously obtained reversed pole position is rigorously precise, then we may infer that the tuffs at Wolf Creek underwent an azimuthal rotation (Hanna, $1968 \mathrm{~b}$ ) of about $35^{\circ}$ in addition to their downward tilting, or that the rocks are now on the flank of a broad anticline plunging $10^{\circ}$ to $15^{\circ}$ north-northwest. By the same argument, we may infer that the rocks at Three Forks underwent little, if any, azimuthal rotation, that any existing fold axis is horizontal, and that the rocks may have assumed initial dips of as much as $5^{\circ}$ to $15^{\circ}$ northward at the time of deposition, although geologic field relations do not suggest large initial dips. Although there is reason to believe that the mean reversed pole position is valid on the basis of comparison with other North American data (Hanna, 1967, p. 607), it is not to be expected that individual volcanic units were all magnetized exactly parallel to this mean direction. Magnetizations of individual units may reflect short-term variations in the ancient magnetic field, or they may consist of some recently acquired magnetization components not randomized in the partial demagnetization process. We may conclude broadly that (1) the Late Cretaceous magnetic field was reversed during emplacement of the tuffs at each site, although it is not known whether emplacements at each site occurred during the same reversed epoch, and locally that (2) if the field was reversed, the tuff sequence at Three Forks is also right-side-up, not an unexpected fact.

An outstanding problem regarding the glassy tuffs at each site, in addition to their unexplained resistance to devitrification over a period exceeding $70 \mathrm{~m} . \mathrm{y}$., is the source of their strong remanent magnetization intensity relative to adjacent stony tuffs. It is suggested on the basis of the previously described petrological and chemical data and on the basis of previously established relations of increasing magnetic coercivities with decreasing grain size and increasing internal stress (Nagata, 1961) that much of the remanent magnetization of the vitreous tuffs is contained in single-domain submicroscopic iron oxide constituents within the glass itself. Rigorous documentation of this suggestion awaits future work. 
HANNA

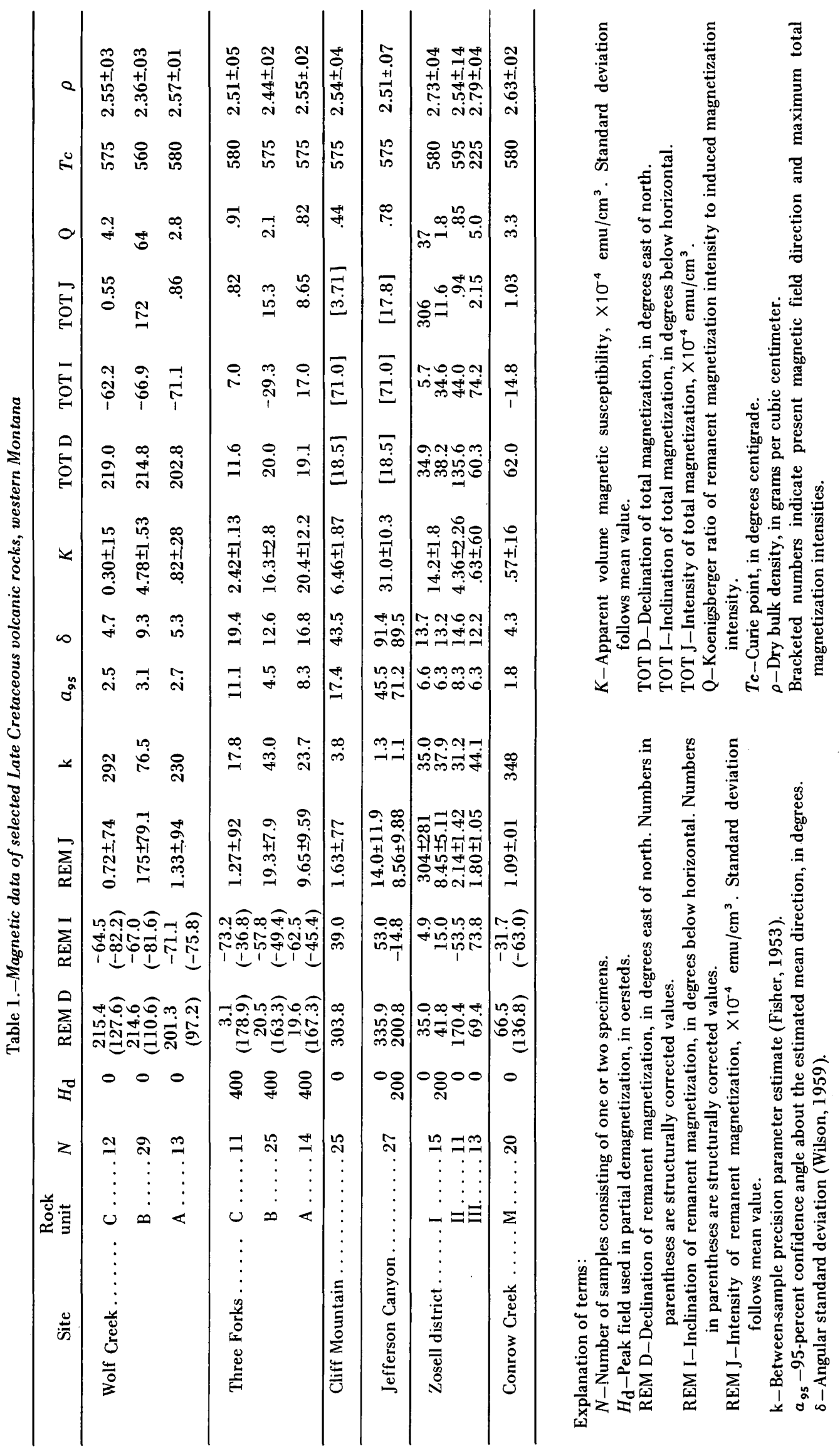



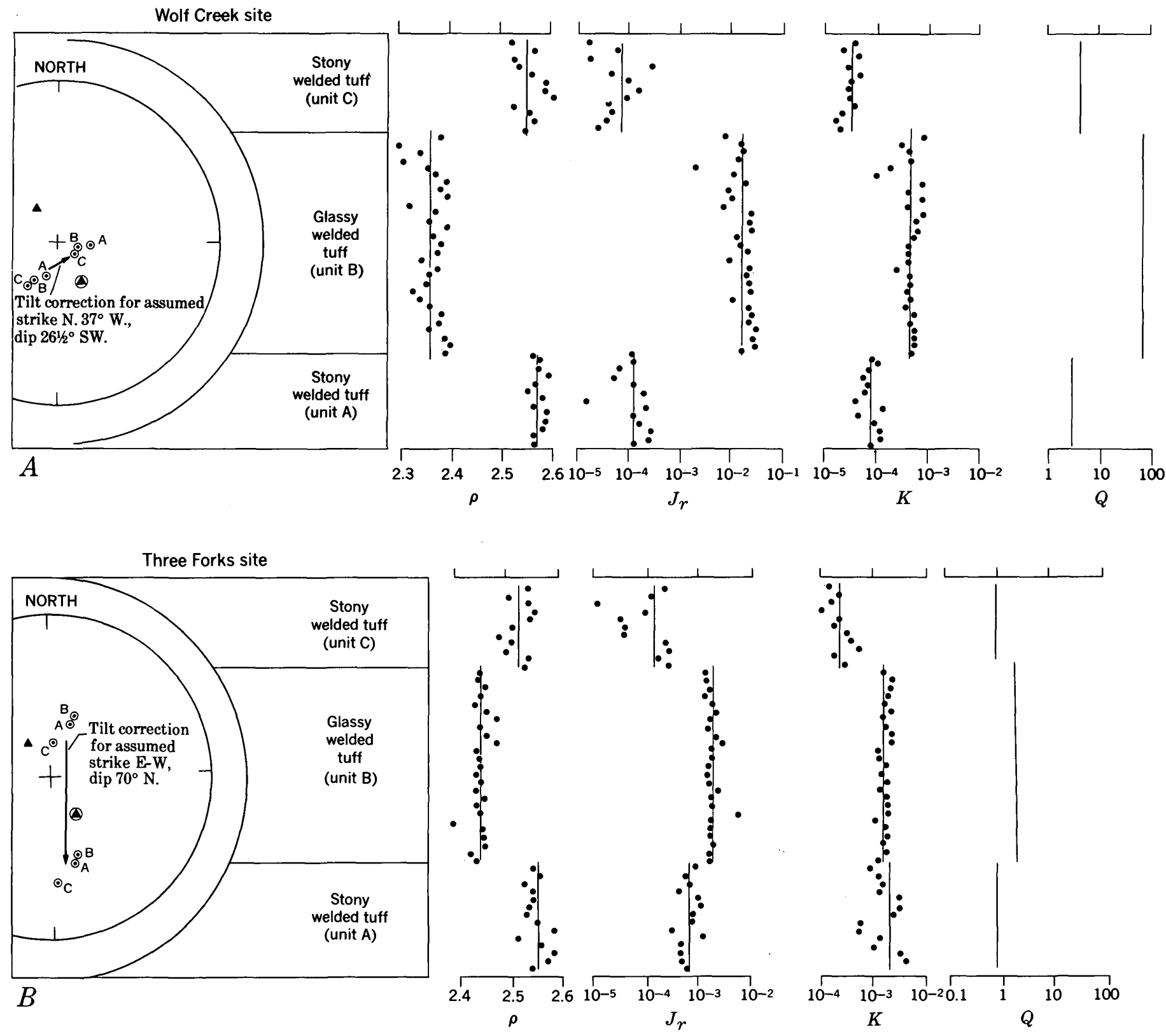

\section{EXPLANATION}
- Normal Late Cretaceous Elkhorn Mountains Volcanics. Pole position based on previous work
(4) Reversed Late Cretaceous Elkhorn Mountains Volcanics. Pole position based on previous work
- Upper hemisphere projection ( reversed polarity)

$$
\begin{aligned}
& \rho=\begin{array}{l}
\rho \text { dry bulk density in grams per } \\
\text { cubic centimeter }
\end{array} \\
& J_{r}=\begin{array}{l}
\text { remanent intensity of magnetization } \\
\text { in emu per cubic centimeter }
\end{array} \\
& K=\begin{array}{l}
\text { apparent volume magnetic susceptibility } \\
\text { in emu per cubic centimeter }
\end{array} \\
& \begin{array}{l}
Q= \\
\text { Koenigsberger ratio of remanent } \\
\text { magnetization intensity to }
\end{array} \\
& \quad \text { induced magnetization intensity } \\
& \mid=\text { mean value }
\end{aligned}
$$

Figure 3.-Inverse relation between rock density and magnetization for glassy and stony welded tuffs from the Wolf Creek and Three Forks sites. Equal-area projections at left show mean remanent magnetization directions before and after structural correction. $A$, Wolf Creek site. The glassy welded tuff unit is approximately $2 \mathrm{~m}$ thick. $B$, Three Forks site. The glassy welded tuff unit is approximately $5 \mathrm{~m}$ thick. 


\section{VOLCANIC BRECCIAS}

\section{Occurrence and description}

Two units of breccia about $75 \mathrm{~km}$ apart are considered to have the most precise K-Ar dates among rocks of the Elkhorn Mountains volcanic field. The northern occurrence (locality 3 ; lat $46^{\circ} 22.09^{\prime} \mathrm{N}$., long $112^{\circ} 30.18^{\prime} \mathrm{W}$.) is part of a sequence of flow breccias (Ruppel, 1961; 1963) that crop out near the crest of Cliff Mountain, about $18 \mathrm{~km}$ east-southeast of Deer Lodge (fig. 1). At the collecting site, the rocks have an average strike of $\mathrm{N} .25^{\circ} \mathrm{W}$. and an average dip of $10^{\circ} \mathrm{SW}$. The southern occurrence (loc. 4 ; lat $45^{\circ} 49.63^{\prime} \mathrm{N}$., long $111^{\circ} 51.07^{\prime}$ W.) is a unit of autoclastic flow breccia (Robinson and others, 1968 , p. 567) that crops out in Jefferson Canyon, $7 \mathrm{~km}$ northwest of Sappington and only $10 \mathrm{~km}$ west of the Three Forks glassy tuff site previously discussed. Breccias at both localities are in the lower member of the Elkhorn Mountains Volcanics (Robinson and others, 1968, p. 567). They have an average strike of east-west and an average dip of $80^{\circ} \mathrm{N}$., although part of this may be initial dip of the volcaniclastic material.

\section{Age}

K-Ar dating of hornblende from rocks at the Cliff Mountain site gives an age of 77.6 $\pm 2.4 \mathrm{~m} . \mathrm{y}$. Hornblende K-Ar dates of two samples from the Jefferson Canyon site are 78.8 \pm 2.4 m.y. and $77.6 \pm 2.4 \mathrm{~m} . y$. (Robinson and others, 1968, p. 567). These ages not only are internally consistent but also conform well to the inferred history of volcanism and plutonism in the area (Robinson and others, 1968; Tilling and others, 1968).

\section{Magnetization}

The chief magnetic characteristic of the breccias at each site is the relatively large dispersion of remanent magnetization directions (figs. 4 and 5). This dispersion is reflected in the large angular standard deviation values, $\delta$, and small precision parameter estimates, $\mathrm{k}$, corresponding to the data of each site (table 1), the $\delta$ values having greater significance in view of the non-Fisherian geometry (Fisher, 1953) of the distributions.

At Cliff Mountain, the remanent magnetization directions of 24 out of 25 samples from a 75-sq-mi outcrop area are generally confined to the lower northwest octant of the projection (fig. 4). This octant contains the mean normal pole position previously obtained for the Elkhorn Mountains Volcanics (Hanna, 1967). Hardness of remanence was confirmed in a-c demagnetization work. If a fossil magnetization of, say, some combination of thermoremanent, chemical, or detrital origin is assumed, the data indicate that the earth's field was normal at the time of cooling or deposition of the unit. The structural correction required to obtain the predeformation magnetization direction is not sufficiently large at this site to affect this interpretation.

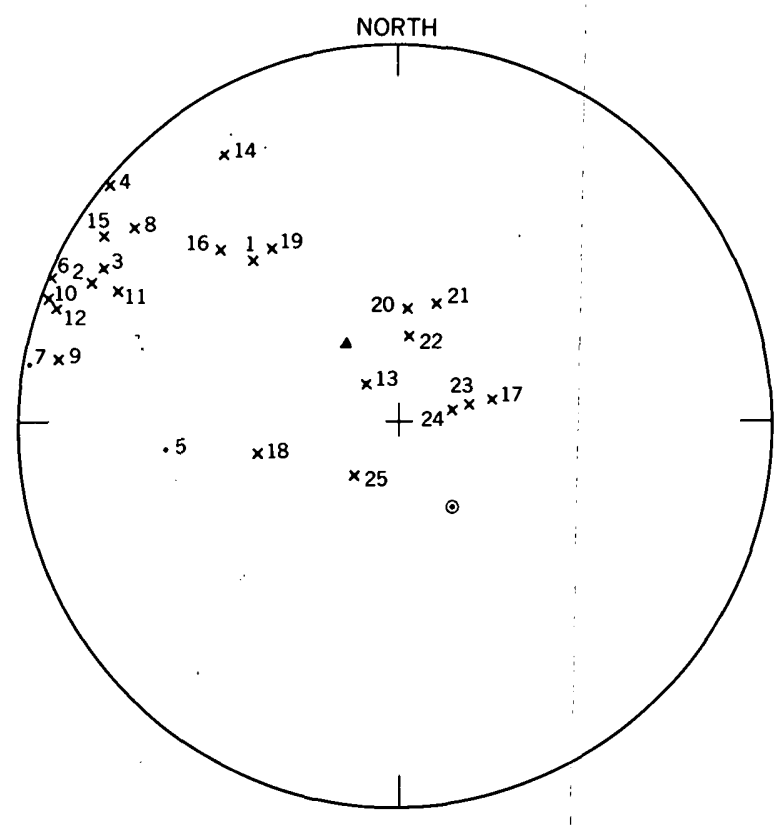

\section{EXPLANATION}

$$
\begin{aligned}
& \text { Lower hemisphere projection } \\
& \text { Upper hemisphere projection } \\
& \text { Normal Late Cretaceous Elkhorn } \\
& \text { Mountains Volcanics. Pole } \\
& \text { position based on previous } \\
& \text { work } \\
& \text { Reversed Late Cretaceous Elkhorn } \\
& \text { Mountains Volcanics. Pole } \\
& \text { position based on previous } \\
& \text { work }
\end{aligned}
$$

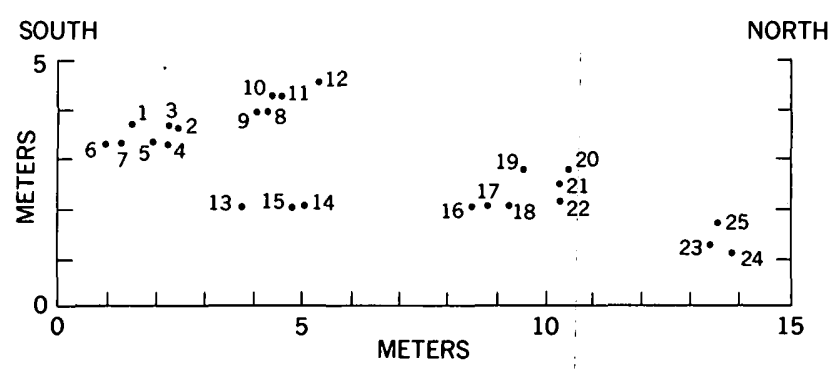

Figure 4.-Equal-area projection of remanent magnetization directions of volcanic breccia from the Cliff Mountain site. Relative locations of samples within the outcrop are shown in lower diagram.

At Jefferson Canyon, where a total of 16 samples are used to illustrate results in figure 5 , samples 1 through 8 were collected from a fresh unoxidized outcrop face solidly in place, and samples 9 through 16 were collected from the outcrop face of a nearby oxidized, slightly disoriented block. Initial remanent magnetization directions of samples from the fresh outcrop are normal but somewhat dispersed, whereas 


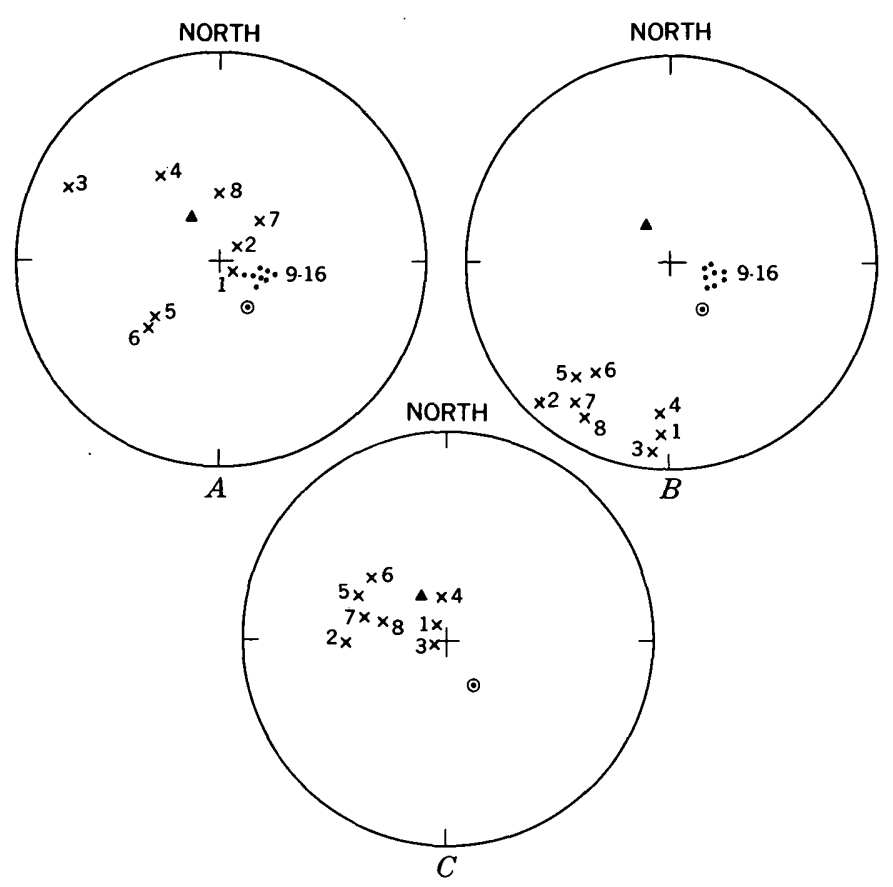

EXPLANATION Lower hemisphere projection .9

Upper hemisphere projection

Normal Late Cretaceous Elkhorn Mountains Volcanies. Pole position based on previous work

Reversed Late Cretaceous Elkhorn Mountains Volcanics. Pole position based on previous work

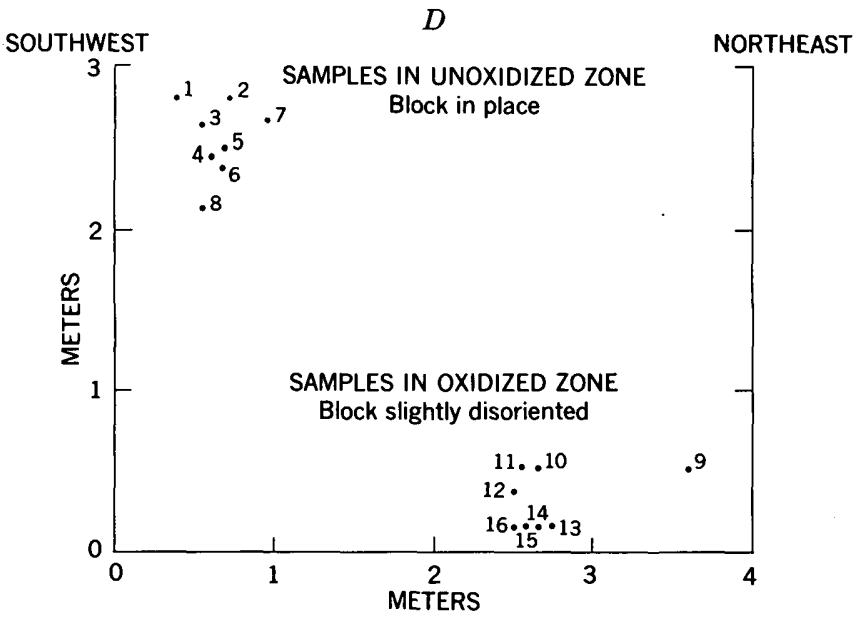

those from the oxidized outcrop are reversed and tightly clustered (fig. $5 A$ ). Partial demagnetization in peak fields of 200 to $400 \mathrm{Oe}$ indicates that the fresh rock has a soft magnetization component and that the oxidized rock is magnetically hard (fig. $5 B$ ). This difference in response to partial demagnetization is an expression of the low-coercivity spinel-type magnetic oxide content of the fresh rock as opposed to the high-coercivity rhombohedral-type oxide content of the oxidized rock.

Structural correction at the Jefferson Canyon site produces remanent magnetization directions corresponding to the fresh outcrop within the lower northwest octant of the projection (fig. $5 C$ ) and directions corresponding to the oxidized block to a southerly, nearly horizontal position (not shown in figure). Data corresponding to the fresh rock are considered to indicate reliably that the ancient field was normal at the time of cooling. Data corresponding to the oxidized rock suggest that a hard magnetization, possibly chemical in origin, was acquired after cooling by magnetic mineral constituents of the ilmenite-hematite series. Although a self-reversal mechanism may have operated within the oxidized rock to produce the resulting reversed magnetization, it is also possible and consistent with other data that a chemical remanent magnetization was acquired after folding in a reversed Late Cretaceous magnetic field. If true, the paleomagnetic field direction is inferred from the original remanent magnetizations, uncorrected for tilt. This latter possibility is strengthened by the Three Forks welded tuff data, which imply the presence of a prefolding reversed manetic field, and by data from elsewhere in the Elkhorn Mountains volcanic field (Hanna, 1965; 1967), which suggest the occurrence of multiple field reversals during volcanic emplacement:

The amount of scatter of remanent magnetization directions in breccias and conglomerates can be used to help distinguish between a relatively hot and cold environment of final deposition (Graham, 1949; Aramaki and Akimoto, 1957; Hanna, 1967; Starkey and Palmer, 1971; Chadwick, 1971). Stated simply, if such rocks have highly dispersed remanent magnetization directions and if the magnetization is thermoremanent in origin, we may infer that clasts have moved somewhat randomly after passing through their Curie temperature range, as they would in cold depositional environments of some mudflows, tuffs, conglomerates, and breccias. If magnetization directions are tightly grouped, we may infer that clasts have not moved after acquiring thermoremanent magnetization, as in warm depositional environments of some breccias and tuffs.

Figure 5.-Equal-area projections of remanent magnetization directions of 16 samples of volcanic breccia from the Jefferson Canyon site. $A$, Original magnetization directions for samples. $B$, Directions for samples after a-c partial demagnetization in peak fields of 200 to 400 Oe. $C$, Directions for partly demagnetized samples (1-8) from unoxidized zone after correction for structural tilt of strike east-west and $\operatorname{dip} 80^{\circ} \mathrm{N} . D$, Relative locations of samples. 
The amount of dispersion in the data from Cliff Mountain and Jefferson Canyon is not considered great enough to imply a cold environment of deposition but is sufficiently great to suggest a warm one in which limited motion of clasts occurred after passing through blocking temperatures of about $575^{\circ} \mathrm{C}$, on the basis of Curie temperature data from representative rock specimens (table 1 ). If the partial thermoremanent magnetization spectrums of the sampled breccias are similar to those obtained elsewhere for basalt and magnetite powder (Nagata, 1961, p. 159, 163), as we might expect them to be on the basis of the magnetite Curie temperatures measured, we may infer that almost all of the magnetization of the breccias was acquired at temperatures above $400^{\circ} \mathrm{C}$. This temperature may be used as a best estimate of the minimum temperature of breccia deposition.

\section{ALTERED BASALTS}

Three localities of basaltic rocks within the Zosell (Emery) mining district, $13 \mathrm{~km}$ east of Deer Lodge (loc. 2, fig. 1), were sampled. Because they occur in an area characterized by a major negative aeromagnetic anomaly (Hanna, 1969, p. D162), these rocks were suspected of having either reversed, anomalously directed, or very weak magnetizations compared to basalts and andesites in other parts of the Elkhorn Mountains volcanic field. In fact, this outcrop area is the only occurrence of the Elkhorn Mountains Volcanics associated with a major aeromagnetic low within the Boulder batholith area, even though many units of the volcanic field have reversed magnetization polarities (Hanna, 1967). Ordinarily, negative aeromagnetic features in the Boulder batholith area are associated with plutonic rocks of the batholith itself or with relatively felsic Lowland Creek Volcanics in broad zones of mineralization.

Rocks within the Zosell district were sampled at three separate locations within a $1-\mathrm{km}$ radius but for purposes of discussion are treated as a single collecting site. Designated I, II, and III in table 1 , these outcrop locations have specific geographical coordinates, respectively, of lat $46^{\circ} 22.52^{\prime} \mathrm{N}$., long $112^{\circ} 34.37^{\prime} \mathrm{W}$; $46^{\circ} 22.38^{\prime}, 112^{\circ} 34.53^{\prime}$; and $46^{\circ} 23.16^{\prime}$, $112^{\circ} 34.28^{\prime}$.

Under the petrologic nomenclature of Robertson (1953, p. 7), outcrops I and II consist of feldspar-pyroxene basalt, and outcrop III consists of pyroxene basalt. Although all three outcrops occur in mineralized zones, only rocks from outcrop II show appreciable megascopic alteration. Black iron oxide is relatively abundant as an accessory mineral in all of the basalts sampled. A modal analysis of pyroxene basalt similar to that of outcrop III shows a magnetite abundance of 4.5 percent (Robertson, 1953, p. 8). Comparison of chemical analyses of pyroxene basalt with those of feldspar-pyroxene basalt similar to rocks sampled suggests that the feldspar-pyroxene unit has a modal magnetite abundance of about 3.5 to 4.0 percent.

The present structural attitudes of rocks at the three outcrops are very difficult, if not impossible, to establish precisely. In areas immediately north and south of the mining district, flows generally strike N. $30^{\circ} \mathrm{W}$. to north-south and $\operatorname{dip} 10^{\circ}$ to $20^{\circ} \mathrm{W}$. (Robertson, 1953, p. 8). Within the mining district a small, tight, west-plunging syncline has been produced in which low-angle reverse fractures and high-angle normal faults occur. The low-angle reverse fractures are considered to be nearly parallel to bedding, whereas the normal faults probably represent tension fractures (Robertson, 1953, p. 8-9).

Attempts were made to determine bedding orientation by use of the alinement of subplanar feldspar laths and amygdules; however, abrupt changes in these orientations suggest occurrences of locally turbulent flow. The ambiguity of structural orientation of the flows where sampled gives rise to corresponding ambiguity of predeformation remanent magnetization directions, as will be seen in a following section.

Thermomagnetic curves for basalts at each locality (fig. 6) are highly contrasting and indicate that the rocks have somewhat different magnetic constituents. The curve for the sample from outcrop I is similar to those of the glasses previously discussed (fig. 2) and is typical for that of nearly
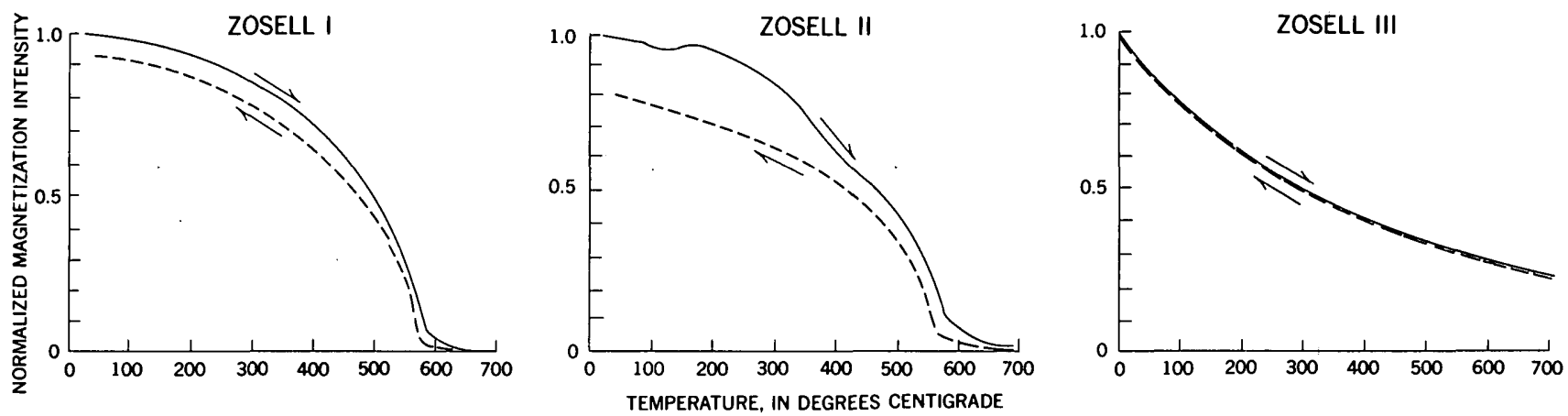

Figure 6.- Thermomagnetic curves for basalts at locations I, II, and III of the Zosell district. Plots of normalized magnetization intensity versus temperature are for external fields of 1,500,2,000, and 4,000 0e, respectively. Measurements made in air. Solid line represents heating cycle; dashed line, cooling cycle. 
pure magnetite. The curve for the sample from outcrop II possesses a conspicuous hump not previously observed in other units of the Elkhorn Mountains Volcanics. The curve for the sample from outcrop III is concave upward throughout the sampled temperature interval and is also unique among curves previously obtained.

Because the flows occur within a mining district rich in hydrothermal deposits and because some specimens of outcrop II show megascopic alteration, it is instructive to compare the thermomagnetic curves with curves obtained elsewhere (Ade-Hall, 1971, p. 8078) for certain hydrothermally and deuterically altered basalt containing class I magnetites (Wilson and others, 1968). If one assumes a general absence of deuteric alteration, on the basis of inspection of thin sections, the curve of outcrop I is similar to that of Ade-Hall's (1971, p. 8078) Mull specimen C120-1, which is characterized by a high regional hydrothermal alteration, inferred by Ade-Hall to have involved maximum reheating temperatures of over $200^{\circ} \mathrm{C}$. The humped curve of outcrop II is similar to that of Ade-Hall's (1971, p. 8078) Mull specimen C190-1, which is characterized by high regional hydrothermal alteration and moderate deuteric oxidation. The rise in magnetization within the temperature interval $150^{\circ}-375^{\circ} \mathrm{C}$ may be attributable to a relatively rapid change of the magnetic mineral to material having a higher Curie temperature during the heating process, as suggested by Ade-Hall (1971, p. 8078) for other rocks. The smooth, reversible, concave-upward curve for outcrop III, which was exactly reproduced in duplicate thermomagnetic experiments, has no sharply defined Curie temperature. A temperature of $225^{\circ} \mathrm{C}$ was estimated, which would suggest a spinel-phase ferromagnetic mineral intermediate in composition between pure magnetite and ulvospinel (Nagata, 1967, p. 502). Curves of this type for samples heated in air are unknown to the author in the literature, and they indicate a resistance of the magnetic mineral against further oxidation as well as an anomalously high retentivity of magnetic moment at temperatures exceeding $700^{\circ} \mathrm{C}$. The curve might indicate the presence of a spectrum of titanomagnetites of varying composition within the rock such as Doell and Cox (1965b, p. 3383) inferred for Hawaiian basaltic flows having thermomagnetic curves with no well-defined knees. The presence of abundant hemoilmenite within the rock having a Curie temperature of $225^{\circ} \mathrm{C}$ has been ruled out on the basis of its absence in petrographic analysis and the response of the rock to demagnetizing fields.

Age

Although none of the basalts sampled have been radiometrically dated, all belong to the Elkhorn Mountains Volcanics (Klepper and others, 1957; Smedes, 1966) of Late Cretaceous age (Robinson and others, 1968). The basalts were provisionally included in the uppermost unit of the Elkhorn Mountains Volcanics by E. T. Ruppel in 1957 (Ruppel, 1961), although the outcrops are only about $5 \mathrm{~km}$ from the 78-m.y.-old volcanic breccia of Cliff Mountain, assigned to the upper part of the lower unit of the Elkhorn Mountains Volcanics (Robinson and others, 1968, p. 567). For purposes of the present investigation, the rocks are adequately time bracketed by the assigned Late Cretaceous age.

\section{Magnetization}

Mean remanent magnetization directions of the flows at outcrops I, II, and III are highly contrasting, having inclinations that are horizontal, reversed, and normal, respectively. These directions, together with possible predeformation directions inferred from various structural corrections, are shown in figure 7 . The ambiguity of the various possible predeformation directions is reduced by recognizing that the most reliable structural corrections are based on regional structure, the local synclinal structure, and the low-angle reverse fractures (designated 1,2 , and 3 for each outcrop in figure 7 ). Any one or combination of inferred structurally corrected directions 1,2 , or 3 of each outcrop locality indicates that (a) the predeformation direction of outcrop I was anomalous, being nearly horizontal, (b) that of outcrop II was reversed with moderate inclination, and (c) that of outcrop III was normal and steeply inclined.

The possibility of self-reversed magnetization or anomalous chemical remanent magnetization must be admitted for each of the localities sampled within the mining district in view of the thermomagnetic data and field evidence of regional hydrothermal activity. However, there is a lack of definite petrographic evidence for oxidized or exsolved rhombohedralphase magnetic mineral often suggestive of self-reversal, and a-c demagnetization indicates no evidence of anomalously high coercitivities characteristic of the rhombohedral phase. Thus, with caution, we may allow for the possibility that any one or all of the localities express the polarity of the ancient field at the time of cooling. If the magnetization is fossil, a relatively rapid reversal of the ancient field was presumably required because of the inferred short time interval required for extrusion.

The most significant magnetic intensity characteristic of the sampled basalts is the strong total magnetization intensity of about $3 \times 10^{-2} \mathrm{emu} / \mathrm{cm}^{3}$ for outcrop I. Rocks from outcrops II and III have total magnetizations about one and two orders of magnitude weaker and are less important as active sources of aeromagnetic anomalies.

\section{SIGNIFICANCE OF RESULTS}

\section{Paleomagnetic interpretation}

The most important conclusion of the present study is the confirmation of previous inferences about multiple field reversals accompanying extrusion of the Elkhorn Mountains Volcanics, now fixed at about 78 m.y. ago. The exact polarity 


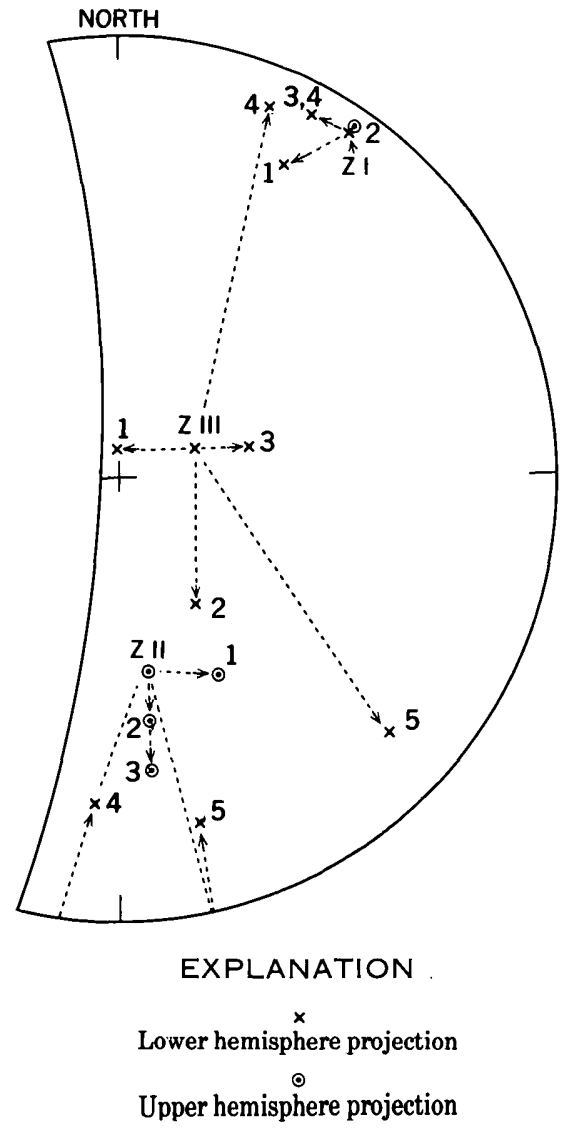

ORIGINAL REMANENT MAGNETIZATIONS

$Z$ I: Zosell location I

Z II: Zosell location II

Z III: Zosell location III

POSSIBLE STRUCTURAL CORRECTIONS

1 Regional structure

2 Local synclinal structure

3 Low-angle reverse fractures

4 Steep-dipping veined fractures

5 Local alinement of vesicles and feldspar laths

Figure 7.-Equal-area projection of mean remanent magnetization directions of basalt from three locations in the Zosell district. Numbers refer to various structural corrections that might be made to establish predeformation mean pole positions.

sequence still cannot be precisely established, but it is evident from present and previous work that a minimum of two complete field reversal cycles occurred and that as many as eight complete cycles may have occurred during volcanic rock emplacement.

The firm establishment of multiple field reversals approximately $78 \mathrm{~m} . y$. ago is important for two reasons. First, the data serve to revise the chronology of field polarities inferred by Heirtzler and others $(1968$, p. 2123$)$ on the basis of marine magnetic anomalies near the maximum point of extrapolation at about 79 m.y. Second, the data indicate that a $30-\mathrm{m} . y$. interval of normal field polarity preceding $78 \mathrm{~m} . \mathrm{y}$., cited by Helsley and Steiner (1969, p. 328) on the basis of compilations of paleomagnetic data, was interrupted not by a simple reversed epoch but rather by a series of field reversal cycles. It is anticipated that paleomagnetic work on the Late Cretaceous Boulder batholith, which was intruded into the Elkhorn Mountains volcanic field between 78 and 68 m.y. ago, will help determine whether or not this succession of polarity reversals continued to the close of the Cretaceous Period.

The northeasterly, nearly horizontal remanent magnetization of basalt I at the Zosell district, if primary, may represent another example of rapid paleomagnetic field migration previously suggested by Grommé and Gluskoter (1965) and Saad (1969) on the basis of results from the Jurassic and Cretaceous Franciscan Formation of California and by Spall (1968) on the basis of results from late Mesozoic dolerites of Norway. Somewhat similar anomalous magnetization directions have been found in the Late Cretaceous Boulder batholith of Montana (Hanna, unpub. data, 1966-68), the Eocene Siletz River Volcanics of Oregon (Cox, 1957), and the Eocene Lowland Creek Volcanics of Montana (Hanna, unpub. data).

\section{Aeromagnetic interpretation}

Among the three groups of rocks discussed (tuffs, breccias, and basalts), three individual rock units have sufficiently strong remanent magnetizations and one rock unit has a sufficiently strong induced magnetization to be important as possible sources of aeromagnetic anomalies. The rock units with strong remanent magnetizations are the glasses of Wolf Creek and Three Forks and the basalt of locality I in the Zosell mining district, all having total magnetization intensities of greater than $10^{-3} \mathrm{emu} / \mathrm{cm}^{3}$. These units are designated 1,2 , and 5 on the aeromagnetic maps and equal-area projection of figure 8 . The rock unit with strong induced magnetization is the breccia at Jefferson Canyon, which also has a total magnetization of greater than $10^{-3} \mathrm{emu} / \mathrm{cm}^{3}$, whether or not the somewhat dispersed, normally polarized remanent magnetization is considered to contribute to the total magnetization. This breccia unit is designated 4 in figure 8 and is shown with the breccia from Cliff Mountain (3, fig. 8 ) because of the latter's proximity to the Zosell site.

In view of the criteria necessary for a rock to constitute the source of an aeromagnetic anomaly, namely, that its magnetization must be strong relative to surrounding rocks and that its volume in the subsurface must be large relative to the distance between source and magnetometer, only the basalt from the Zosell district and the breccia from Jefferson Canyon meet both requirements. Thus, the major negative anomaly centered near the basalt exposure and the weaker positive anomaly nose at the breccia site may be inferred to be caused, at least in part, by the sampled rocks extending into the subsurface (fig. 8). The glasses at Wolf Creek and Three Forks, which are very 

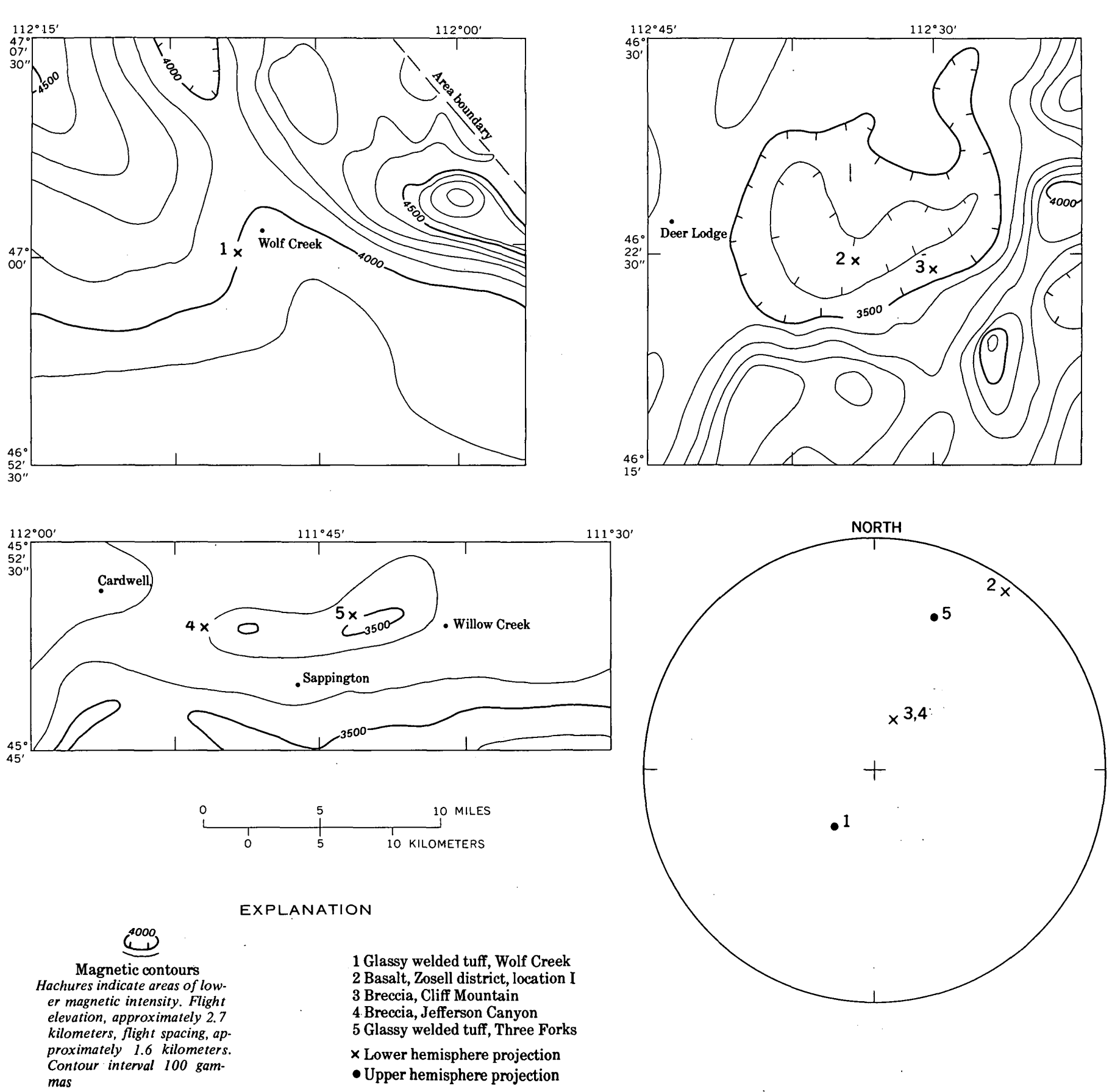

EXPLANATION

1 Glassy welded tuff, Wolf Creek

2 Basalt, Zosell district, location I

3 Breccia, Cliff Mountain

4. Breccia, Jefferson Canyon

5 Glassy welded tuff, Three Forks

Figure 8.-Generalized aeromagnetic maps of sampling localities, and equal-area projections of mean total magnetizations of rocks sufficiently magnetic to be considered in aeromagnetic interpretation. Magnetic intensities are listed in table 1. Sources of aeromagnetic data: upper left, Kleinkopf and Mudge (1972); upper right, Johnson, Henderson, and Tyson (1965); and lower left, Davis, Kinoshita, and Robinson (1965).

limited in outcrop extent and which were relatively distant from the surveying magnetometer, do not have the volume needed to contribute appreciably to the aeromagnetic patterns, despite their strong magnetizations. The absence of negative anomalies associated with the reversed magnetizations of these glassy tuffs indicates that the glasses are minor elements within the volcanic piles.
Of primary interest in aeromagnetic interpretation are the basalts that occur within the Zosell mining district. On the basis of measured magnetizations and previous magnetic model calculations (Hanna, 1969), the broad negative aeromagnetic anomaly centered near the district is generated not so much by rocks with strong reversed magnetizations but rather by rocks with strong horizontal magnetizations in association with 
other rocks having variously polarized weak magnetizations. If the correlation between negative aeromagnetic anomalies and zones of hydrothermal alteration continues to be valid for subsurface rocks extending northward from the Zosell district, the aeromagnetic data to the north may define undiscovered zones of subsurface mineralization and therefore have economic value.

\section{REFERENCES CITED}

Ade-Hall, J. M., 1971, Discussion of paper by Minoru Ozima and Mituko Ozima, "Characteristic thermomagnetic curve in submarine basalts": Jour. Geophys. Research, v. 76, no. 32, p. 8077-8079.

Ade-Hall, J. M., Wilson, R. L., and Smith, P. J., 1965, The petrology, Curie points, and natural magnetizations of basic lavas: Royal Astron. Soc. Geophys. Jour., v. 9, no. 4, p. 323-326.

Akimoto, Syun-iti, and Katsura, Takashi, 1959, Magneto-chemical study of the generalized titanomagnetite in volcanic rocks: Jour. Geomagnetism and Geoelectricity [Kyoto], v. 10, no. 3, p. 69-90.

Aramaki, Shigeo, and Akimoto, Syun-iti, 1.957, Temperature estimation of pyroclastic deposits by natural remanent magnetism: Am. Jour. Sci., v. 255, no. 9, p. 619-627.

Barksdale, J. D., 1951, Cretaceous glassy welded tuffs-Lewis and Clark County, Montana: Am. Jour. Sci., v. 249, no. 6, p. 439-443.

Chadwick, R. A., 1971, Paleomagnetic criteria for volcanic breccia emplacement: Geol. Soc. America Bull., v. 82, no. 8, p. 2285-2294.

Colville, A. A., 1961, Paleomagnetic investigation in the vicinity of the northern Tobacco Root Mountains, Madison County, Montana: Indiana Univ., Bloomington, Ind., Ph. D. thesis, 148 p.

Cox, Allan, 1957, Remanent magnetism of lower to middle Eocene basalt flows from Oregon: Nature, v. 179, no. 4561, p. 685-686.

Creer, K. M., and Petersen, N., 1969, Thermochemical magnetization in basalts: Zeitschr. Geophysik, v. 35, no. 5, p. 501-516.

Davis, W. E., Kinoshita, W. T., and Robinson, G. D., 1965, Bouguer gravity, aeromagnetic, and generalized geologic map of the western part of the Three Forks Basin, Jefferson, Broadwater, Madison, and Gallatin Counties, Montana: U.S. Geol. Survey Geophys. Inv. Map GP-497, scale 1:62,500.

Doell, R. R., and Cox, Allan, 1965a, Measurement of the remanent magnetization of igneous rocks: U.S. Geol. Survey Bull. 1203-A, p. $\mathrm{A} 1-\mathrm{A} 32$.

1965b, Paleomagnetism of Hawaiian lava flows: Jour. Geophys. Research, v. 70, no. 14, p. 3377-3405.

$1967 \mathrm{a}$, Analysis of alternating field demagnetization equipment, in Collinson, D. W., Creer, K. M., and Runcorn, S. K., eds., Methods in paleomagnetism: Amsterdam, Elsevier Co., p. 241-253.

- 1967b, Recording magnetic balance, in Collinson, D. W., Creer, K. M., and Runcorn, S. K., eds., Methods in paleomagnetism: Amsterdam, Elsevier Co., p. 440-444.

Fisher, R. A., 1953, Dispersion on a sphere: Royal Soc. London Proc., ser. A, v. 217, no. Al130, p. 295-305.

Graham, J.W., 1949, The stability and significance of magnetism in sedimentary rocks: Jour. Geophys. Research, v. 54, no. 2, p. $131-167$.

Grommé, C. S., and Gluskoter, H. J., 1965, Remanent magnetization of spilite and diabase in the Franciscan Formation, western Marin County: Jour. Geology, v. 73, no. 1, p. 74-94.

Grommé, C. S.., Wright, T'. L., and Peck, D. L., 1969, Magnetic properties and oxidation of iron-titanium oxide minerals in Alae and Makaopuhi lava lakes, Hawaii: Jour. Geophys. Research, v. 74, no. 22, p. $5277-5293$

Hanna, W. F., 1965, Magnetic properties of selected volcanic rocks of southwestern Montana: Indiana Univ., Bloomington, Ind., Ph. D. thesis, $207 \mathrm{p}$.
Hanna, W. F., 1967, Paleomagnetism of upper Cretaceous volcanic rocks of southwestern Montana: Jour. Geophys. Research, v. 72, no. 2, p. 595-610.

1968a, Preliminary analysis of an induction-type apparatus for measuring magnetic susceptibility [abs.]: Am. Geophys. Union Trans., v. 49, no. 4, p. 673.

-1968b, Remanent magnetization of two late Cretaceous glassy volcanic rocks from Montana [abs.] : Am. Geophys. Union Trans., v. 49 , no. 4 , p. 671 .

1969, Negative aeromagnetic anomalies over mineralized areas of the Boulder batholith, Montana, in Geological Survey Research 1969: U.S. Geol. Survey Prof. Paper 650-D, p. D159-D167.

Heirtzler, J. R., Dickson, G. O., Herron, E. M., Pitman, W. C., and LePichon, Xavier, 1968, Marine magnetic anomalies, geomagnetic field reversals, and motions of the ocean floor and continents: Jour. Geophys. Research, v. 73, no. 6, p. 2119-2136.

Helsley, C. E., and Steiner, M. B., 1969, Evidence for long intervals of normal polarity during the Cretaceous period: Earth and Planetary Sci. Letters, v. 5, no. 5, p. 325-332.

Johnson, R. W., Jr., Henderson, J. R., and Tyson, N. S., 1965, Aeromagnetic map of the Boulder batholith area, southwestern Montana: U.S. Geol. Survey Geophys. Inv. Map GP-538, scale $1: 250,000$.

Kleinkopf, M. D., and Mudge, M. R., 1972, Aeromagnetic, Bouguer gravity, and generalized geology of the Great Falls-Mission Range area, northwestern Montana: U.S. Geol. Survey Prof. Paper 726-A. [In press]

Klepper, M. R., and Smedes, H. W., 1959, Elkhorn Mountains volcanic field, western Montana [abs.]: Geol. Soc. America Bull., v. 70, no. 12 , pt. 2, p. 1631.

Klepper, M. R., Weeks, R. A., and Ruppel, E. T., 1957, Geology of the southern Elkhorn Mountains, Jefferson and Broadwater Counties, Montana: U.S. Geol. Survey Prof. Paper 292, 82 p.

Knopf, Adolph, 1957, The Boulder bathylith of Montana: Am. Jour. Sci., v. 255, no. 2 , p. 81-103.

Lyons, J. B., 1944, Igneous rocks of the northern Big Belt Range, Montana: Geol. Soc. America Bull., v. 55, no. 4, p. 445-472.

Nagata, Takesi, 1961, Rock magnetism: Tokyo, Japan, Maruzen Co. Ltd., $350 \mathrm{p}$.

1967, Identification of magnetic minerals in rocks using methods based on their magnetic properties, in Collinson, D. W., Creer, K. M., and Runcorn, S.K., eds., Methods in paleomagnetism: Amsterdam, Elsevier Co., p. 501-513.

Parry, L. G., 1965, Magnetic properties of dispersed magnetite powders: Philos. Mag., v. 11, no. 110, p. 303-312.

Phillips, J. D., and Kuckes, A. F., 1967, A spinner magnetometer: Jour. Geophys. Research, v. 72, no. 8, p. 2209-2212.

Robertson, F. S., 1953, Geology and mineral deposits of the Zosell (Emery) mining district, Powell County, Montana: Montana Bur. Mines and Geology Mem. 34, 29 p.

Robinson, G. D., 1963, Geology of the Three Forks quadrangle, Montana, with section on the petrography of igneous rocks, by H. F. Barnett: U.S. Geol. Survey Prof. Paper 370, 143 p.

Robinson, G. D., and Marvin, R. F., 1967, Upper Cretaceous volcanic glass from western Montana: Geol. Soc. America Bull., v. 78, no. 5, p. 601-608.

Robinson, G. D., Klepper, M. R., and Obradovich, J. D., 1968, Overlapping plutonism, volcanism, and tectonism in the Boulder batholith region, western Montana, in Coats, R. R., Hay, R. L., and Anderson, C. A., eds., Studies in volcanology: Geol. Soc. America Mem. 116, p. 557-576.

Ruppel, E. T., 1961, Reconnaissance geologic map of the Deer Lodge quadrangle, Powell, Deer Lodge, and Jefferson Counties, Montana: U.S. Geol. Survey Mineral Inv. Field Studies Map MF-174, scale $1: 48,000$ 
1963, Geology of the Basin quadrangle, Jefferson, Lewis and Clark, and Powell Counties, Montana: U.S. Geol. Survey Bull. 1151, $121 \mathrm{p}$.

Saad, A. H., 1969, Paleomagnetism of Franciscan ultramafic rocks from Red Mountain, California: Jour. Geophys. Research, v. 74, no. 27, p. 6567-6578.

Sanver, M., and O'Reilly, W., 1969, Identification of naturally occurring non-stoichiometric titanomagnetites: Physics Earth and Planetary Interiors, v. 2, no. 3, p. 166-174.

Schmidt, R. G., 1963, Preliminary geologic map and sections of the Hogan 4 Southeast quadrangle, Lewis and Clark County, Montana: U.S. Geol. Survey Misc. Geol. Inv. Map I-379, scale $1: 24,000$.

Smedes, H. W., 1966, Geology and igneous petrology of the northern Elkhorn Mountains, Jefferson and Broadwater Counties, Montana: U.S. Geol. Survey Prof. Paper 510, 116 p.

Spall, Henry, 1968, Anomalous paleomagnetic poles from late Mesozoic dolerites from Spitsbergen: Earth and Planetary Sci. Letters, v. 4, no. 1, p. 73-78.

Starkey, J., and Palmer, H. C., 1971, The sensitivity of the conglomer- ate test in paleomagnetism: Royal Astron. Soc. Geophys. Jour., v. 22 , no. 3 , p. $235-240$.

Tilling, R. I., Klepper, M. R., and Obradovich, J. D., 1968, K-Ar ages and time span of emplacement of the Boulder batholith, Montana: Am. Jour. Sci., v. 266, no. 8, p. 671-689.

Uyeda, Seiya, 1958, Thermo-remanent magnetisn as a medium of paleomagnetism, with special reference to reverse thermo-remanent magnetism: Japanese Jour. Geophysics, v. 2, no. 1, p. 1-123.

Viele, G. W., and Harris, F. G., III, 1965, Montana Group stratigraphy, Lewis and Clark County, Montana: Am. Assoc. Petroleum Geologists Bull., v. 49, no. 4, p. 379-417.

Wasilewski, P. J., 1968, Magnetization of ocean basalts: Jour. Geomagnetism and Geoelectricity [Kyoto], v. 20, no. 3, p. 129-154.

Wilson, R. L., 1959, Remanent magnetism of Late Secondary and Early Tertiary British rocks: Philos. Mag., v. 4, no. 42, p. 750-755.

Wilson, R. L., Haggerty, S. E., and Watkins, N. D., 1968, Variation of paleomagnetic stability and other parameters in a vertical traverse of a single Icelandic lava: Royal Astron. Soc. Geophys. Jour., v. 16, no. 1, p. 79-96. 


\title{
GEOLOGIC BENCH MARKS BY TERRESTRIAL PHOTOGRAPHY
}

\author{
By HAROLD E. MALDE, Denver, Colo.
}

\begin{abstract}
A photograph made with a level camera, if taken at a known height above a permanent mark on the ground, can be later repeated with exactness for measurement of changes in terrain. Such a photograph is one of several means for establishing a geologic bench mark and is especially useful for monitoring the subtle qualities of a landscape that are otherwise hard to map and describe, including the effects of man's use. Moreover, the geometry of such a photograph provides the same angular measurements between objects as can be made with a transit. A measurement of distance on a single photograph, however, requires control points. These can be surveyed at any convenient time, not necessarily when the initial photograph is made. Distances can also be determined by simple stereophotography from a base line of suitable length.
\end{abstract}

This paper deals with the use of repeated photographs in field geology as records of a changing land. I began to think about this subject years ago when I heard Ansel Adams, the famous photographer and teacher, tell about his troubles in finding the exact site from which an old photograph had been taken in Canyon de Chelly, Ariz.-a search that fortunately resulted in his celebrated picture of White House Ruin. Mr. Adams, of course, did not precisely duplicate the older photograph; he improved on it. His creative impulse was nonetheless stimulated by a photographic document of the past. Like others before him, Mr. Adams had benefited from the added value of a photograph after a lapse of time.

My thesis is that the value of terrestrial photographs for the future measurement of change can be enhanced by some simple techniques: mainly the marking of the camera position and, where practical, the making of photographs as stereopairs. These techniques make an ordinary field photograph an exceedingly detailed document of the existing landscape, and photographs made by these methods can be routinely repeated with exactness at some future time with whatever camera is then available. In short, the camera becomes a tool for establishing a geologic bench mark.

Terrestrial photographs have many obvious advantages over other methods of recording changes in landscapes, although standard methods of surveying (including vertical aerial photographs) can never be replaced. Observations for the Vigil Network, for example, although derived mainly by standard surveys, depend also on photographs (Emmett and Hadley, 1968). The camera sees all the intricate qualities of terrain that may otherwise escape notice: the staining of outcrops, the cracking of soil, small rills made by runoff on bare ground, the growth of plants, the impact of man's use, and countless other features that are virtually impossible to map and describe by other means. These aspects, moreover, are recorded by the camera impartially and completely, without the bias of observing only selected features that are expected to change. In an article on stream pollution, Wolman (1971, p. 916) remarked that the quality of the rivers themselves should be monitored, not just the quality of the water. The camera is an ideal tool for this purpose. From a stance on the ground, the camera accurately documents the landscape as the eye then sees it, even though the mind may later forget. Moreover, the qualities that can be pictured by photography can be determined at small expense in the ordinary course of fieldwork.

I recently became directly involved with the documentary qualities of photographs when I retraced the steps of several pioneer geologists in New Mexico by finding the places that they had photographed. With their photographs in hand, I was able to determine the actual sites where their tripods had stood and also, in some instances, the hour-by-hour routine of their daily rounds. My motive in this search, besides a desire to know their life on the trail, was to compare new photographs with the old and thereby to document changes in the land. In this pleasant work I was following the example of Hastings and Turner (1965), who had measured the changing plant cover of southern Arizona and adjacent Mexico by repeated photography. In a similar way, my duplicates of early photographs showed me that the landscape of New Mexico had also changed perceptibly in a relatively short time. I further learned that the early photographs would have been easier to repeat if the pioneer geologists had marked their localities. The degree of my success, at least for some of the early photographs, can be judged from figures $1-4$.

The idea of using photography for field documentation is, of course, as old as the camera itself. Frederick Catherwood, the architect who traveled with John Lloyd Stephens in 1838-42 in Central America and Yucatán, besides making extraordinarily accurate drawings of the Maya ruins with a camera lucida, also tried to use a daguerreotype apparatus for the same purpose shortly after Daguerre's invention was introduced in Europe (von Hagen, 1947, p. 209, 232). Later, 


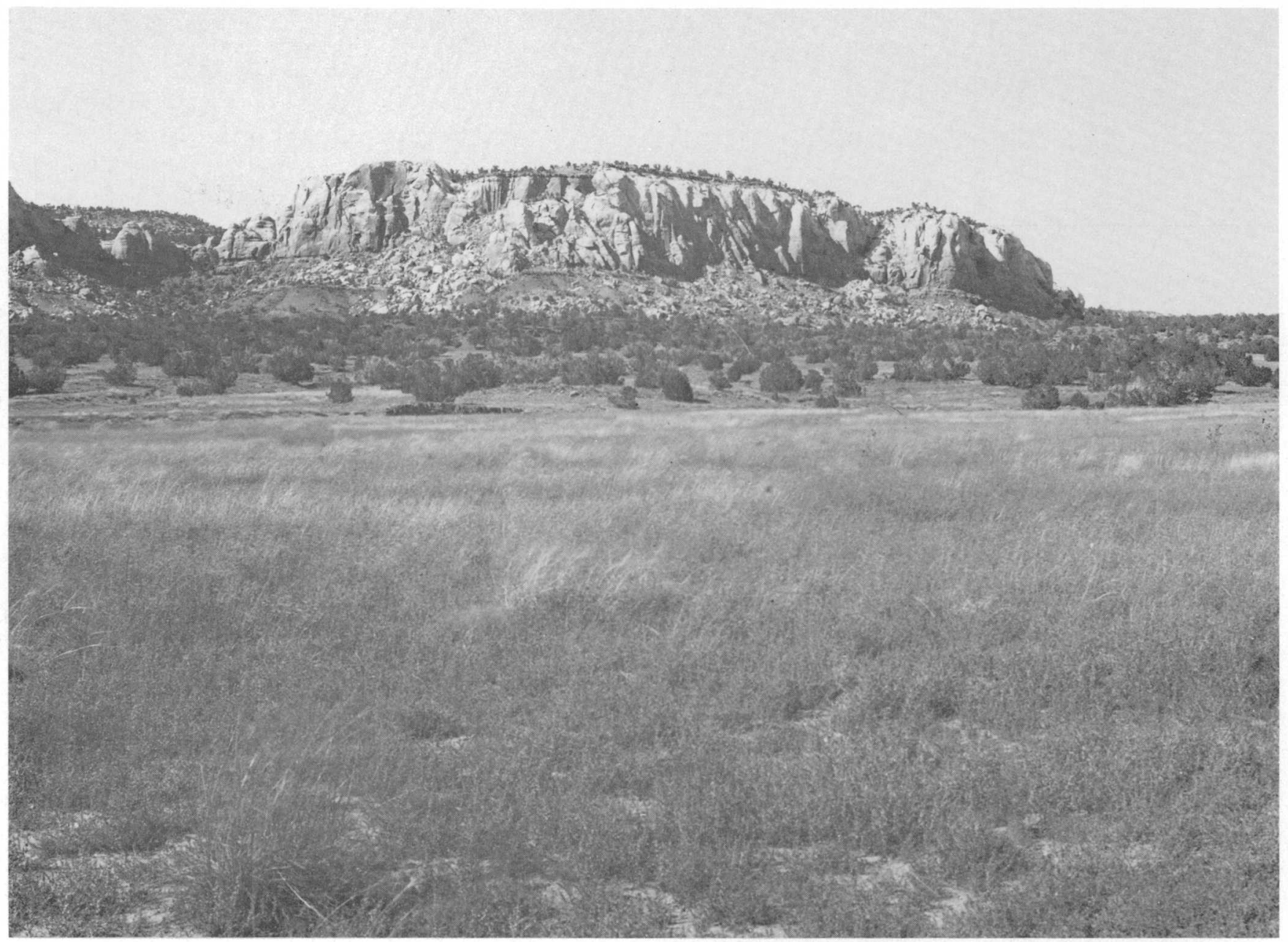

Figure 1.-The White Bluffs in the Ojo Hedionda and Wildhorse Mesa 71/2-minute quadrangles, Santa Fe County, N. Mex., as seen from the grassy alluvial bottomland along Arroyo de la Jara, 0.4 mile southeast of the Pueblo Chey ruins. The center of view is N. $7^{\circ}$ E., but the photograph has been cropped on the right. Arroyo de la Jara lies beyond the field of view at the left and is probably incised, as shown by the bank of a tributary arroyo in the middle distance. The photograph is enlarged from a 5- by 7-inch glass-plate negative made with a lens of 200-mm focal length by N.H. Darton in September 1915. (Darton photograph 1478 in field records of U.S. Geological Survey, Denver, Colo.)

as photographic methods were perfected, terrestrial photogrammetry got its start in repeated surveys by Prof. Sabastian Finsterwald of the changing aspect of glaciers in the eastern Alps in 1888 and 1889 (Hattersley-Smith, 1966). This surveying technique has been actively practiced in rugged terrain ever since, building on the pioneer work of Finsterwald and his son, Richard (Case, 1961; Konecny, 1966). The more elementary technique of making repeated photographs from marked locations for geologic observation was probably first conceived in the United States in 1896 by Israel Russell who, as a member of a U.S. Geological Survey group on a reconnaissance of Mount Rainier, recommended systematic photography and measurement of the terminus of Nisqually Glacier (Russell, 1898, p. 399-400).

Despite Russell's early endorsement, repeated photography has seldom been practiced as a method of geologic research, although many geologists have been avid photographers of landscapes. Russell's recommendation for photography of Nisqually Glacier was eventually adopted nearly half a century later with establishment in 1942 of a network of regularly scheduled photographs (Veatch, 1969). Hastings and Turner (1965) gave credit to a botanist, Homer L. Shantz of the University of Arizona, as a dedicated photographer of representative landscapes. At the time of his death in 1958, Shantz was repeating his early photographs in the northern Great Plains that date back to 1908-a project since completed by his associate of the time, Walter S. Phillips (1963). The examples from geology, other than the photographs of Nisqually Glacier, have been published sparingly at wide intervals-perhaps the most remarkable of these being the recent duplicates by $\mathrm{Hal} \mathrm{G}$. Stephens of photographs taken by E.O. Beaman during the 1871 Powell Expedition, of which only a few have been published thus far as matched pairs (Baars and Molenaar, 1971, p. 89-99). Some other examples 


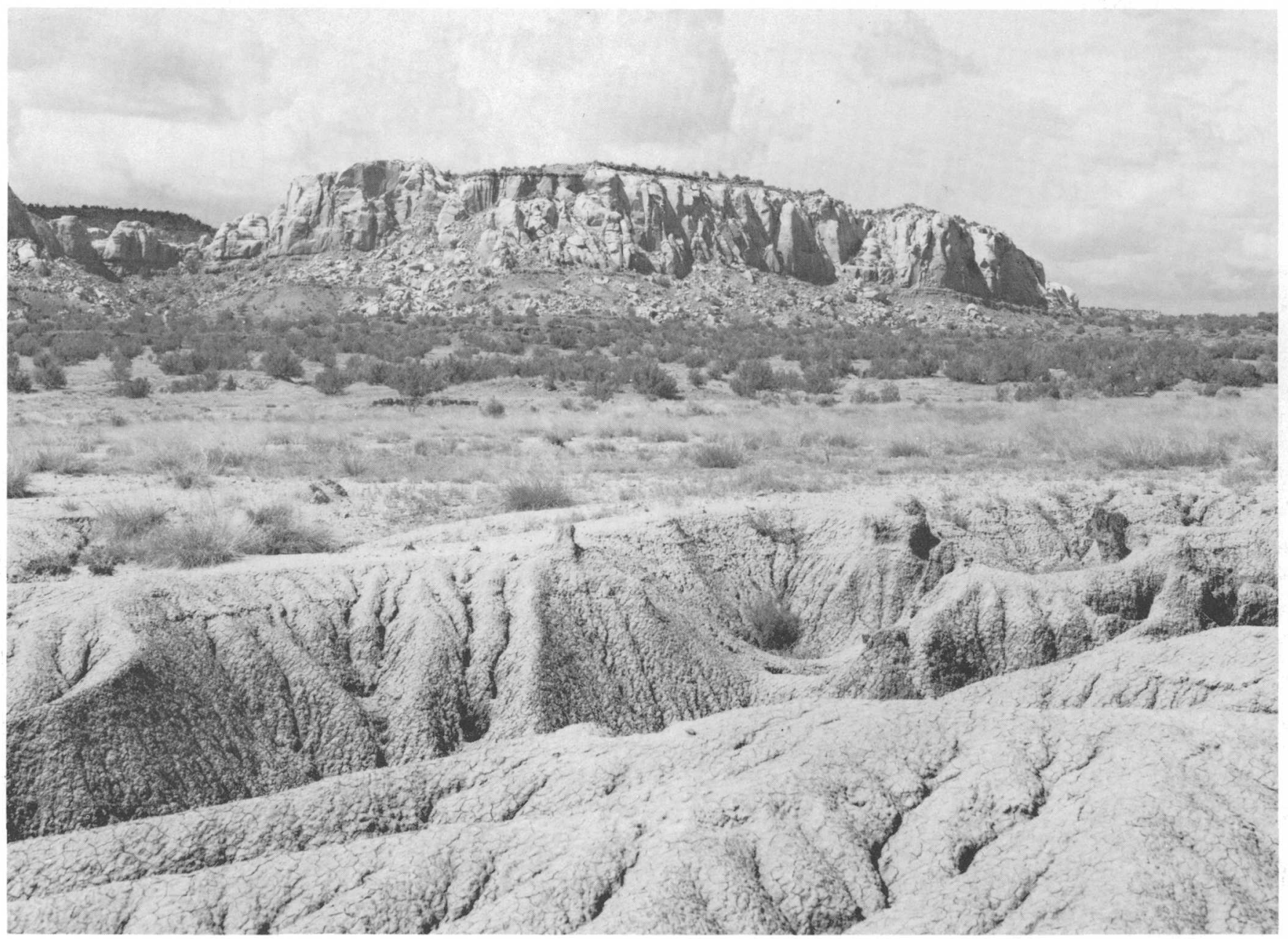

Figure 2.-Duplicate of Darton photograph 1478 (fig. 1), taken August 10, 1970, at 1525 hours mountain daylight time. The photograph has been cropped on the right to match the cropping of the photograph by Darton. Gully erosion since Darton's time is conspicuous in the alluvium of the foreground, but very little change is visible in the grassland beyond. The juniper-pinyon woodland of the middle distance is also substantially the same. Blocks that lie as talus below the White Bluffs appear to be unchanged. The photograph is enlarged from a 4 - by 5 -inch stable-film negative made with a lens of 162-mm focal length. (Malde photograph 546 in field records of U.S. Geological Survey, Denver, Colo.)

of the use of photographs to interpret geologic change are in reports by Shepard and Grant (1947), Leopold (1951), Harrison (1960), and Bryant (1971). In this paper, I hope to encourage more geologists to adopt the idea of Russell by making reproducible photographs of all types of geologic landscapes as a means for future measurement of change. The purpose is not to use the photographs for measurement when they are first made, but is rather to accumulate archives of photographs that can be later repeated from marked localities.

\section{MAKING PHOTOGRAPHIC RECORDS}

Most geologists take photographs, but their usual photographs are impossible to duplicate exactly. The accurate matching of photographs for the measurement of change requires records that specify the position of the camera that was used for the original photograph. Foreground details, which are often the features easiest to measure because they have the largest apparent size in a field photograph, are especially hard to locate precisely without a record of the initial camera position. Thus, records of current photographs must be kept if the photographs are to be accurately duplicated later. Such records make a photograph a geologic bench mark.

The primary record of the camera position is a permanent mark on the ground. If possible, this mark should be placed by hanging a plumb bob from the center of the lens, with the camera mounted on a tripod. A steel rod half an inch in diameter makes a good mark when driven into the ground. The rod then becomes a datum for surveys of control points in the photograph, when needed later to determine the amount of change. The height of such a rod above the ground can also be noted for subsequent measurement of erosion or the buildup of sediment. 


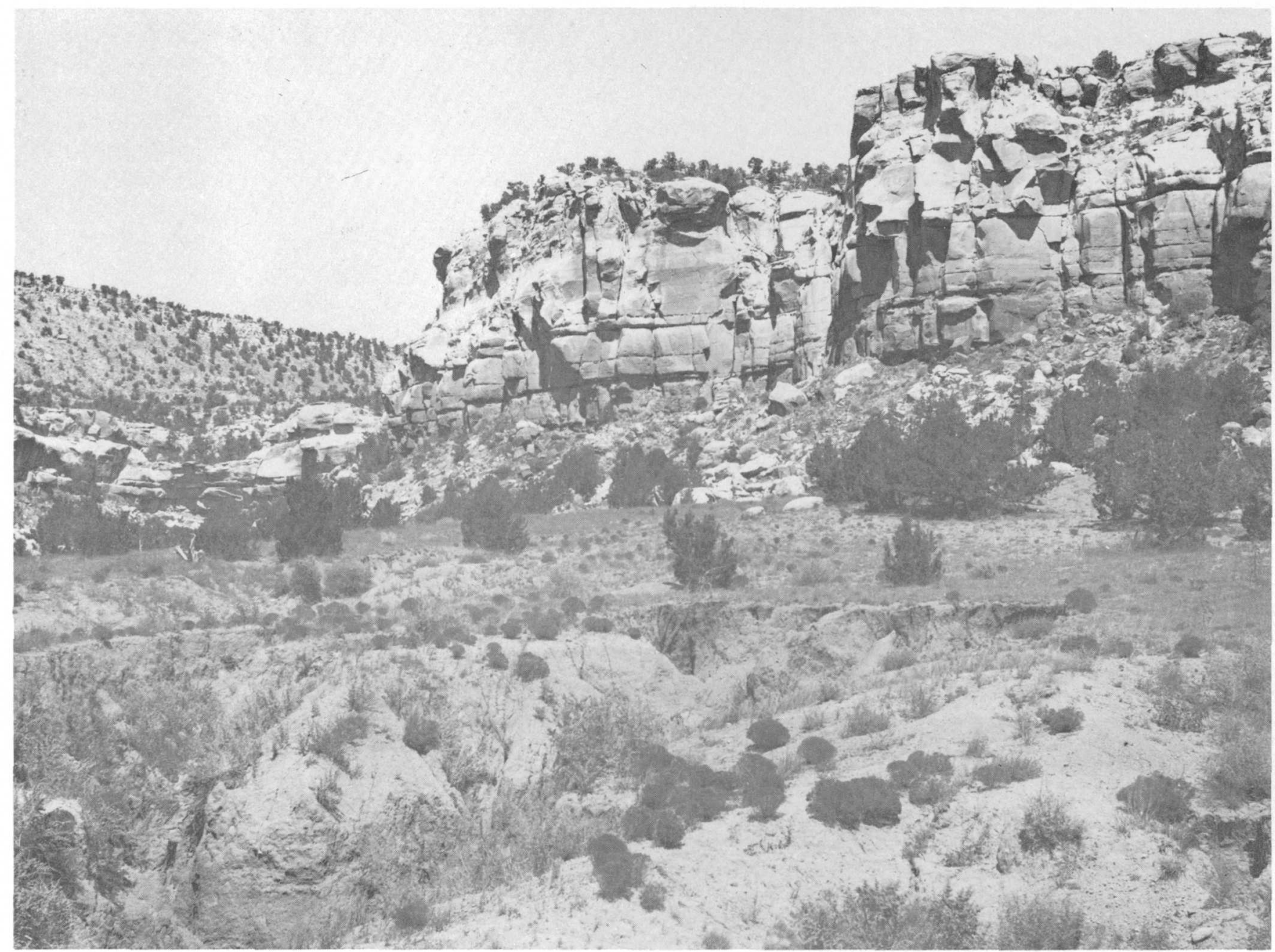

Figure 3.-The White Bluffs in the Ojo Hedionda 71/2-minute quadrangle, Santa Fe County, N. Mex., as seen from the nearby edge of Arroyo de la Jara, 0.6 mile west-northwest of the Pueblo Chey ruins. The center of view is N. $22^{\circ}$ E., but the photograph has been cropped on both the left and right, and a leftward tilt of $8^{\circ}$ in the attitude of the camera has been corrected. The photograph is enlarged from a 5 - by 7 -inch glass-plate negative made with a lens of $200-\mathrm{mm}$ focal length by N.H. Darton in September 1915. (Darton photograph 1477 in field records of U.S. Geological Survey, Denver, Colo.)

Other records about the initial camera position enable later photographers to place a camera above a mark with a high degree of exactness. These records are the height of the camera lens above the mark, the inclination of the camera if not level, and the azimuth of the camera axis. Quite obviously, these variables can be determined accurately only by placing the camera on a tripod.

The inclination can be read with a Brunton compass, but a better method is to place the camera level; the gain in additional foreground or height from an inclined perspective is not usually worth the trouble of duplicating the camera angle at a later time. An inclined camera also makes the geometry of a photograph needlessly complicated for subsequent measurement of geologic change (Williams, 1969, p. 139-147; Janke, 1972).

Finding the azimuth of the camera amounts to measuring the direction of the central aiming point. Clearly, the photograph can be repeated more easily if the aiming point is a conspicuous object at a distance, and such an aiming point can be described in the notes for later reference. Of course, to aim a level camera, the aiming point can be anywhere along a vertical line through the center of the field of view. Some cameras, however, lack a focusing screen with marks to determine the aiming point. In this circumstance, the center of the photograph is itself a rather accurate indicator of the aim of the camera, and the azimuth can be noted approximately.

A note about the date and hour of a photograph, although not absolutely essential for repeated photography, enhances the value of a field photograph as a geologic document.

Geologists who anticipate that active geologic processes might influence the vegetation of a landscape, or that changes in the vegetation might modify the geologic processes, may wish to collect voucher specimens of the plants and soils when a photograph is made. 


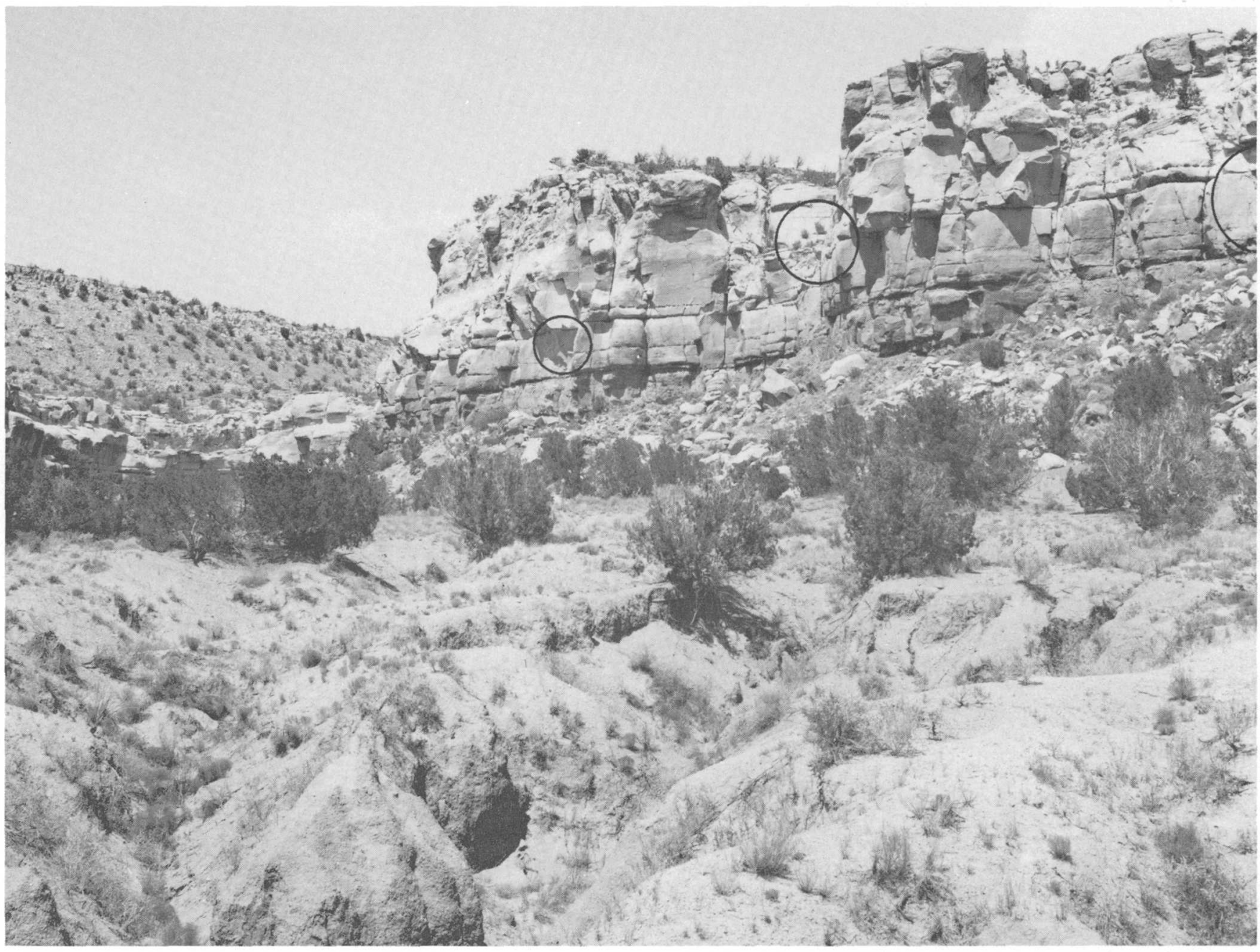

Figure 4.-Duplicate of Darton photograph 1477 (fig. 3), taken August 11, 1970, at 1425 hours mountain daylight time. The trees of Darton's day in the middle distance, although now larger, mark the headward growth of the foreground gullies. Large blocks have fallen from three places along the cliff, as marked by circles, thus adding to the talus below. The photograph is enlarged from a 4- by 5-inch stable-film negative made with a lens of 162-mm focal length. (Malde photograph 551 in field records of U.S. Geological Survey, Denver, Colo.)

Records giving the positions of control points in a photograph, although helpful, are not needed for the initial photograph. These points can be identified and surveyed at the time of subsequent photography. An object of known size in a photograph is nonetheless useful in providing a reference for comparison with other objects nearby. A measured object can also be of help in detecting small changes in its vicinity.

A scheme for systematically recording the variables of a level camera at a station, including useful information about the type of film and filter as well as other technical data about the actual photograph, is shown in figure 5. Space is provided for notes on the lateral and vertical movements of the lens on a view camera, relative to the center of the film plane, and for information about the lens and focus. The format is intended for printing on either a 4 - by 5 -inch card or an envelope for 4 by 5 -inch negatives; either way, the record stays with the negative, and a permanent document is provided for storage in an archive. Of course, a working file of these records of photographs should also be kept, partly for convenience, but mainly as a precaution against loss or damage. The notes about a photograph used for a geologic bench mark might include a supplemental photograph that shows the environs of the camera at its marked location. This photograph can be invaluable if the marker is lost.

\section{DUPLICATING PHOTOGRAPHS WITHOUT RECORDS}

If the record of a photograph is missing, the photograph can still be duplicated rather closely, although great care is needed to match details of the foreground. The record that is kept for the new photograph then makes both the old and the new photographs a geologic bench mark for later use. Finding the former placement of a camera depends on the familiar principle of parallax. With the photograph in hand, a position 


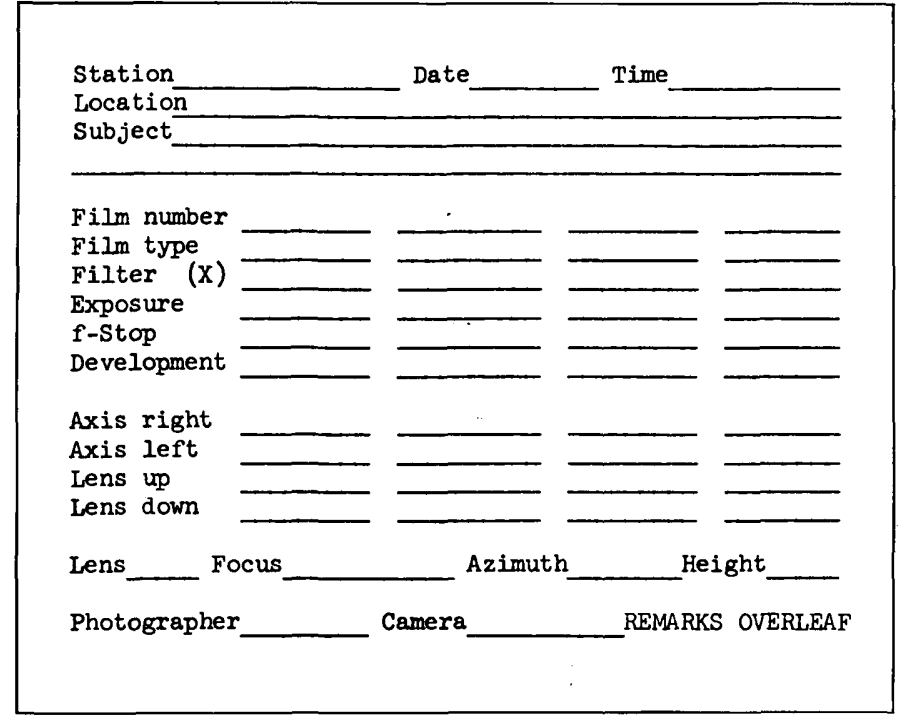

Figure 5.-A format for recording the data of phoiographs used for geologic bench marks.

is found such that near and distant objects in the center of the field of view are brought into approximate alinement. Then, by moving along the centerline, objects at the periphery are alined so that their apparent parallax is also correct. This procedure identifies the aiming point and fixes the camera at the proper distance from the subject. The height of the camera at this distance can generally be determined only by observing the parallax of identifiable objects in the foreground. If the nearby objects are well defined, a few inches of error in the camera position is quite noticeable in the photographic image, and a close match between the old and new photographs thus gives confidence that the original camera placement has been found.

A common fallacy about making duplicate photographs is that the focal length of the new camera should be proportional to that of the old (Curry, 1967b). All that is actually required is that the two cameras occupy the same position (meaning the position of the lens on each camera) and that they be aimed at the same point. These circumstances determine the perspective and all the geometrical properties of the two photographs (assuming that the focal plane of each camera is perpendicular to the lens axis). The broad view of a wide-angle lens obviously cannot be covered by a lens with a narrow angle of view, but a photograph made with a lens of narrow coverage will match the central part of a wide-angle photograph (suitably enlarged) if both photographs are taken from the same place. A similar comment applies to photographs made with different sizes of negatives. For example, Darton used a 5- by 7 -inch camera and a 200-mm lens in New Mexico. His photographs thus covered a lateral angle of view of $47^{\circ}$. The camera $I$ used covered a view of $41^{\circ}$, but the photographs made from his negatives and mine could be matched by enlarging them to the same size.

\section{MEASUREMENT OF THE FOCAL LENGTH}

A knowledge of the focal length of a camera is fundamental for photographic measurements, even on photographs for which the positions of control points have been measured on the ground. The focal length marked on a typical lens is only approximate and is not intended for accurate work, but the true focal length can be measured quickly with ordinary tools that are available to any geologist. The method of measurement that is outlined below is based on a procedure described by G.A. Fischer, formerly of the U.S. Geological Survey (unpub. data). (See fig. 6.)

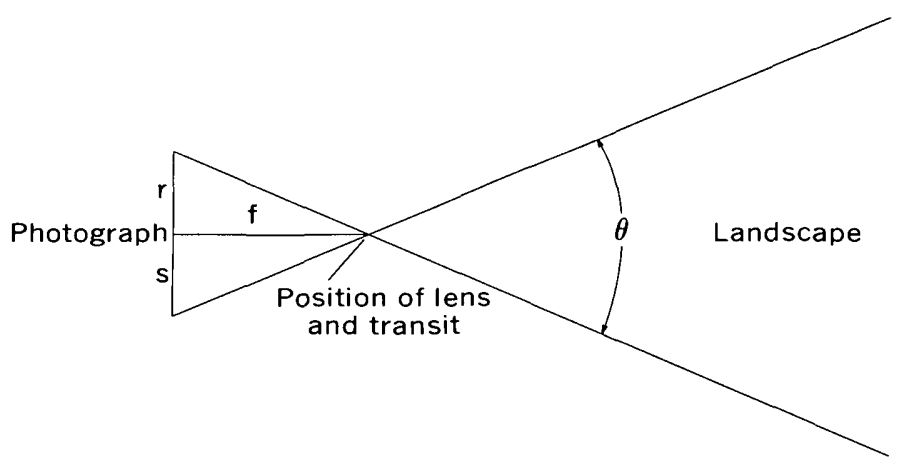

Figure 6.-Diagram of method for measurement of focal length. The symbols are explained in the text.

1. The camera is placed level, a plumb bob is used to mark a point on the ground below the center of the lens, and a photograph is made of a distant landscape that contains sharply defined ohjects such as church steeples and telephone poles for targets.

2. A transit is placed above the point marked on the ground, and the horizontal angle between targets near the left and right margins of the photograph is measured. Call this angle $\theta$.

3. The distances from the center of the photograph to the images of the two target points are measured, preferably on the negative, calling one distance $r$ and the other distance $s$. The measurements are made at right angles to a vertical line through the center. They can be made with an instrument as precise as a comparator or as simple as a giass scale.

4. The focal length, $f$, is computed from the quadratic equation,

$$
f^{2}-\left(\frac{r+s}{\tan \theta}\right) f-r s=0,
$$

which can be solved by standard algebraic methods.

The accuracy of the final result depends on the precision of measurement of the quantities $r, s$, and $\theta$, but Fischer pointed out that. a small error in locating the true center of the 
photograph (which introduces small complementary errors in $r$ and $s$, although not an actual error in their sum) is immaterial. Still, the sum of $r$ and $s$ (meaning the distance between the target points on the negative) must be determined as accurately as possible. For an accuracy of one part in 4,000, which is the practical standard for photogrammetric work, the $r$ and $s$ distance must be measured to a tolerance of $0.04 \mathrm{~mm}$ if the negative is made with a lens having a nominal focal length of $150 \mathrm{~mm}$. For the same accuracy, the angle $\theta$ must be measured to the nearest half minute. The computed focal length would then have a maximum error of $0.05 \mathrm{~mm}$.

In practice, because the focus of a camera may be set for various distances, the focal length should be determined when the camera is focused on nearby objects (for instance, an object at a standard hyperfocal distance marked on the focusing scale), as well as when the camera is focused at infinity. When a field photograph is made, the correction factor for the actual position of focus is recorded.

\section{GEOMETRY OF A HORIZONTAL PHOTOGRAPH}

A photograph made with a level camera of known focal length provides the same general information that can be obtained by surveys with a transit, namely the horizontal and vertical angles between objects in the field of view. The information on the photograph, however, is entirely in terms of distances between these objects as they are pictured in the focal plane. Although the angular relations can be accurately determined with a special instrument-that is, a photogoniometer-the angles are easily calculated from direct measurements of distances on the photograph. These distances can be conveniently measured with either a comparator, a stereometer, or an ordinary glass scale. In practice, the measurements should be made directly on the negative.

T'he angular relations of a point, $Q$, with respect to the center of a photograph, as determined from measurements of two distances and the focal length, are evident in figure 7. For any two points in a photograph, their angular relations are calculated merely by relating their respective horizontal and vertical angles to each other.

The horizontal angle between two points on a photograph can also be calculated directly, as follows. Let $r$ and $s$ be the horizontal distances from the center. Then,

$$
\tan \theta=f\left(\frac{r+s}{f^{2}-r s}\right)
$$

where $f$ is the focal length and $\theta$ is the horizontal angle. This formula is simply a transposition of the formula used for the experimental measurement of the focal length. As before, the $r$ and $s$ distance should be measured as accurately as possible, but small complementary errors in $r$ and $s$ that result from a small error in locating the true center are insignificant.

The vertical angles that can be determined from a photograph depend on distances that are measured from the center

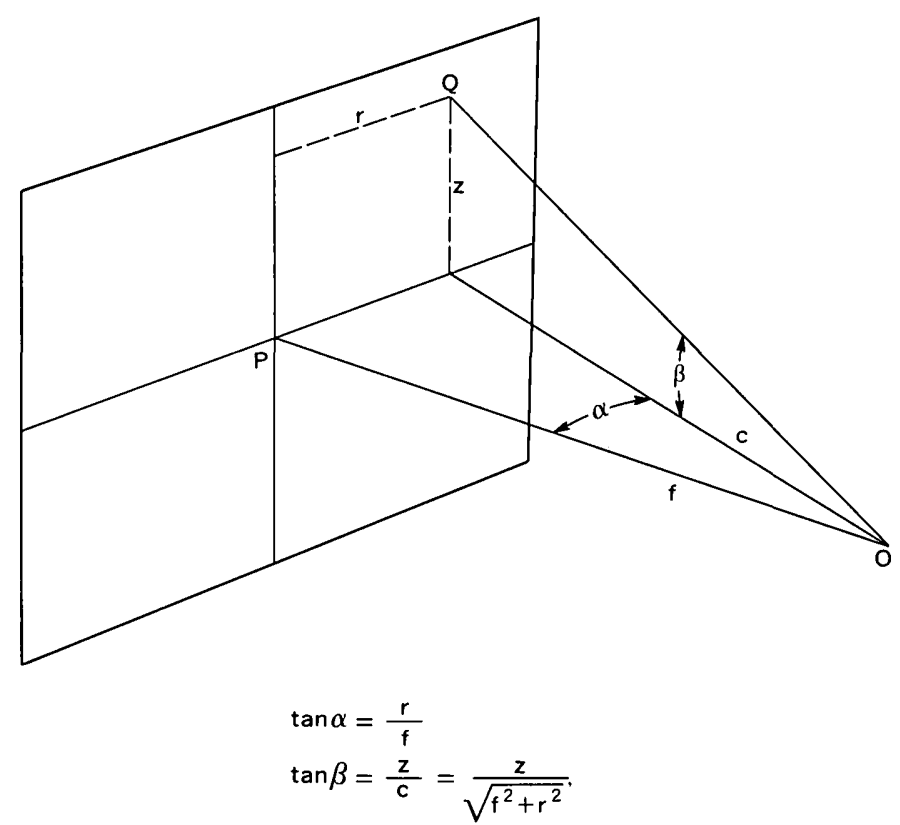

Figure 7.-Perspective diagram of the geometry of a horizontal photograph, where $O$ is the position of the lens, $f$ is the focal length, $P$ is the center of the photograph (also called the principal point), and $Q$ is the image of an object in the focal plane. The horizontal and vertical angles, $a$ and $\beta$, are determined by the focal length and by measurements of $r$ and $z$, using the indicated formulas. (Slightly modified from Strain and Case, 1966, fig. 19-11.)

of the photograph. The center point should be located rather precisely, but even the approximate position of the center point, which can be closely estimated by measurement from the edges or the corners of a photograph, might give a value for the vertical angle that is within the desired tolerance.

A camera can be modified to locate the center point by directly imprinting marks along the edges of the negative at the time of exposure. These should resemble the fiducial marks made by cameras used for aerial mapping. Several methods for adding such marks to negatives are technically feasible, including the direct approach of making notches at suitable places along the frame of the focal plane (Curry, 1.967a). The notches should be made to close tolerances in an instrument shop by use of machine tools. The specifications for a metal slide for making fiducial marks on 4- by 5 -inch film are given on figure 8 . Whatever method is used for making the fiducial marks, their accuracy is uncertain unless they have been calibrated with the actual center of the photographic image. This is an optical procedure beyond the scope of this paper and is best done in an instrument shop equipped for this work.

The task of making measurements on negatives is facilitated by using cameras of large format, even though the burden in the field is greater. In reality, the accuracy of the measurements does not depend on the film size but on the focal length, and lenses of long focal length are typically used mainly on large cameras. Another advantage of larger film sizes 


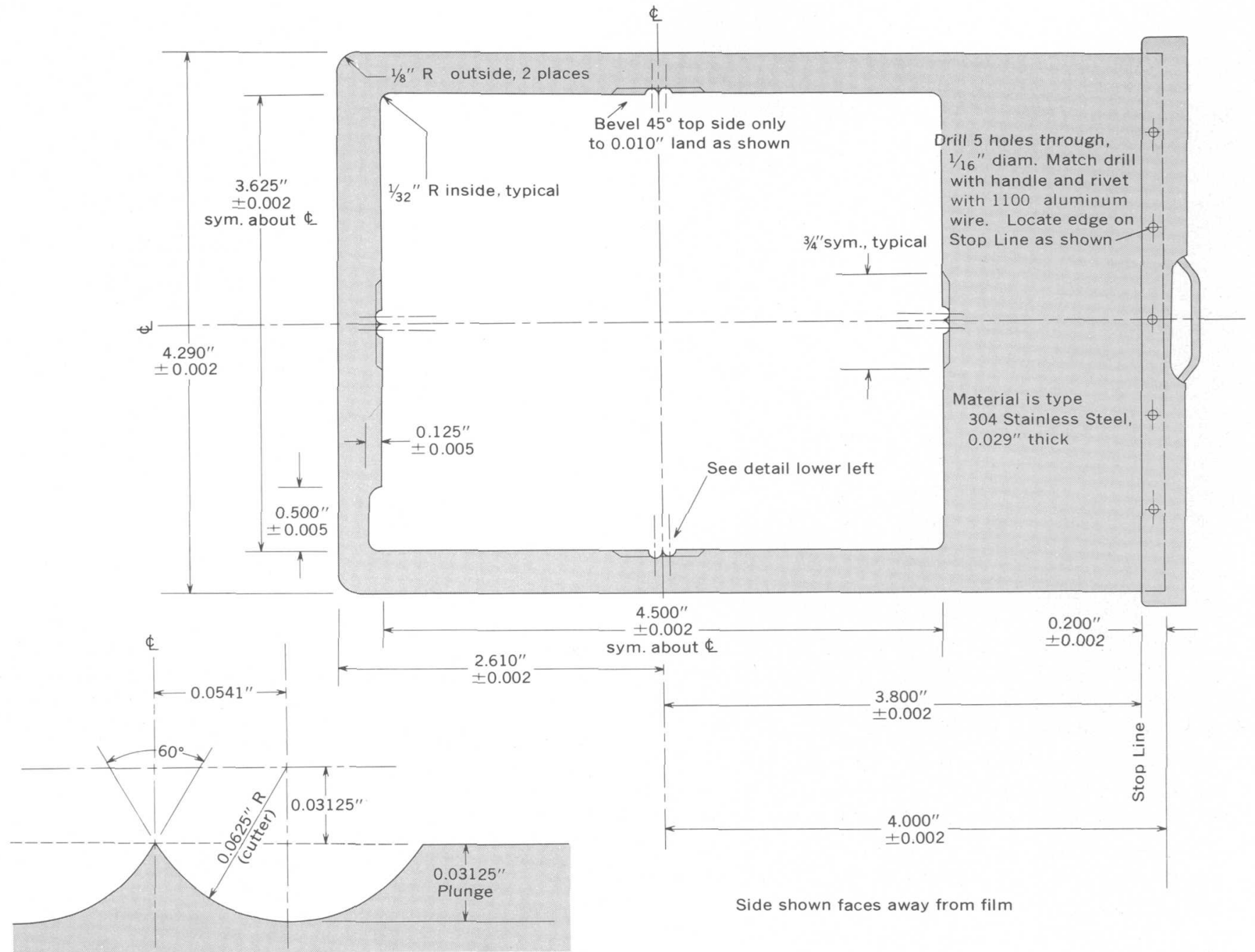

Figure 8.-Engineering drawing of a metal slide for imprinting fiducial marks at the time of exposure on 4- by 5-inch film in a standard film holder. The dark slide of the film holder is removed, and this metal slide is inserted when the photograph is made. After the film is exposed, the metal slide is pulled past the fabric of the light trap with the aid of a sheet of stainless steel, 0.003 inch thick, which is cut to the same size as the metal slide. The sheet of stainless steel is slipped in behind the metal slide, on the side toward the film, and the sheet and metal slide are removed together from the film holder. The marks that are imprinted with this device are not as accurate as those that can be made with rigid markers in other cameras, because of inaccuracies caused by a movable marker in a movable film holder, but the device is a simple means of making fiducial marks that are accurate enough for general work. The design is by Leon B. Lacey, National Center for Atmospheric Research, Boulder, Colo.

(70 $\mathrm{mm}$ and 4 by 5 inches) is that they are currently available in stable polyester material, which is almost as permanent as glass negatives. If work must be done with miniature negatives that are made with lenses of short focal length (35-mm cameras, for instance), the measurements should be made with a precise comparator, not with an instrument of lesser accuracy. Enlargements made from miniature negatives have been suggested as a means of achieving a photograph of convenient size (Williams, 1969; Janke, 1972), but the scale of these enlargements is hard to control, and the enlargements should preferably be made on print film to avoid the differential shrinkage of prints on paper.

The angles that can be measured with a level camera, particularly the horizontal angles, are obviously a direct means of making a map when the distances between a few control points are known. The map can be made either by analytical methods, when the greatest possible accuracy is needed in measuring the position of objects, or by graphical methods, when a lesser accuracy is sufficient. Procedures for mapping from photographs are beyond the scope of this paper, but Williams (1969) gives many practical examples that emphasize graphical techniques. Procedures that depend on plotting instruments are explained by Strain and Case (1966).

\section{SIMPLE STEREOPHOTOGRAPHY}

Geologists have become familiar with stereophotography from their regular use of aerial photographs in geologic 
mapping; but, as Professor Finsterwald showed in the early days of photogrammetry, the principles of stereophotography also apply to pairs of photographs made from the ground. Such stereopairs can be used either to enhance the perception of depth in a photograph of a landscape (Moseley, 1972) or to make actual measurements of terrain, depending on the distance between the pairs and the distance of the subject. Although stereophotographs are widely appreciated, geologists have rarely used them to document the geologic features of landscapes. Fortunately, stereopairs can be made simply and routinely for this purpose. In the discussion that follows, which is based on the use of a level camera, the general principles of terrestrial stereophotographs are outlined, and the methods of making them are explained.

Stereopairs can be made with a single camera either by placing the camera alternately at the ends of a short bar designed for this purpose (See, for example, Curry, 1967a) or by setting the camera successively over the ends of a base line of suitable length. Photographs from a bar would ordinarily be used with a stereoscope for visual study of landscapes, and those from a base line would be used primarily for analytical measurements of distances to nearby objects. The marked ends of the base line provide bench marks for the measurement of distances to control points. These distances, as will be seen, can also be measured directly from the stereophotographs.

Whatever means are used to make stereophotographs, they are all similar in geometry. The essential variables for measurement of a horizontal distance from the base line, using a stereopair, are shown on the diagram of figure 9 . In applying this diagram, the distances $r$ and $s$ can be measured without knowing the true centers of the respective photographs. These measurements can be made from the image of a distant object near the center of the field of view, which is identifiable on both photographs. In this way, an increment that is added to $r$, for example, is subtracted from $s$, and the sum of $r$ and $s$ (or their difference) remains constant.

The range of distance that can be mapped with stereophotographs varies directly with the base line, and a common rule of thumb is that the distance to objects that are to be mapped should be from four to 15 times the length of the base line. This rule stems from a standard formula in photogrammetry, which expresses the error in the measurement of distance as follows:

$$
d=\frac{h^{2}}{b f} e
$$

where $d$ is the error in the distance, $h$ is the distance from the camera to the object, $b$ is the length of the base line, $f$ is the focal length of the camera, and $e$ is the error of measurement on the photograph. For example, if the measurement error is $0.1 \mathrm{~mm}$, a stereopair made with a $150-\mathrm{mm}$ lens from a base line $10 \mathrm{~m}$ long would have a resultant distance error of $1.5 \mathrm{~m}$ for an object $150 \mathrm{~m}$ away (an error of 1 percent)-the distance

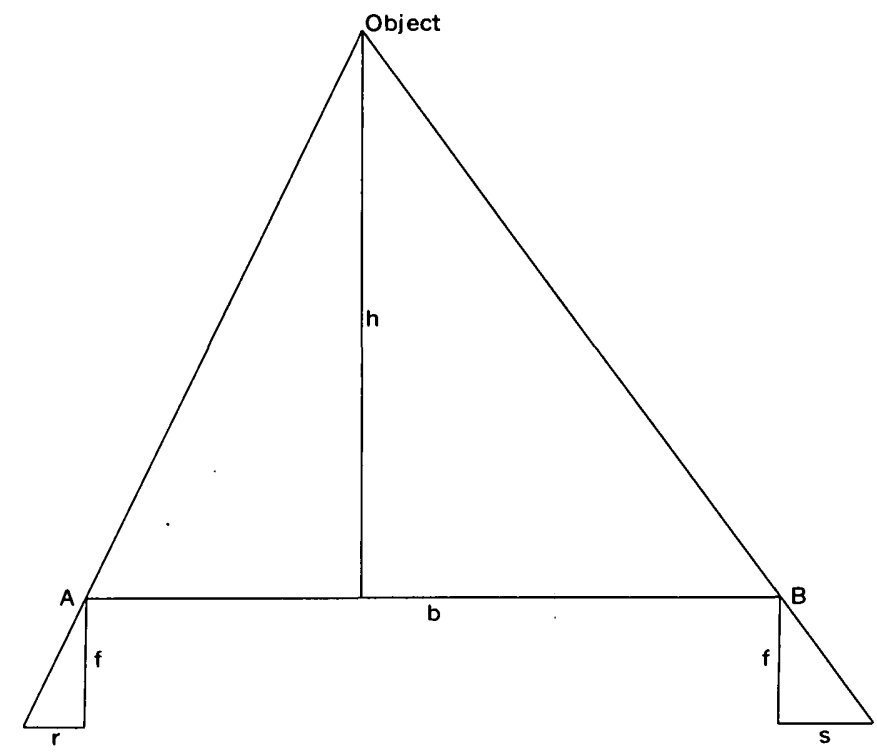

Left photograph

Right photograph

$$
h=b \frac{f}{r+s}
$$

Figure 9.-Diagram of the geometry of a pair of photographs made with a level camera pointed straight ahead from the ends of a base line, $A B$, where $b$ is the length of the base line, $h$ is the distance from the base line to an object in the field of view, $f$ is the focal length, $r$ is the distance from the center of the left photograph to the image of the object, and $s$ is the related distance in the right photograph. The distance to the object is calculated from the indicated formula. The geometry for an object to the left or right of the base line is similar, but the difference between $r$ and $s$ (not their sum) is used in the formula; that is, attention is paid to the sign of $r$ and $s$.

to the object thus being 15 times the length of the base line. The recommended distance to near objects by this rule of thumb is derived from the amount of overlap of typical photographs (Strain and Case, 1966, fig. 1.9-17).

The preceding formula can be used to determine a suitable length for the base line, once the accuracy of measurement on the photograph is known and a tolerance has been adopted for the measurement of objects within the selected range of distance. If objects closer than this range must be mapped, an intermediate camera station can be located along the base line.

After the distance to an object has been determined from a stereopair, the vertical difference in elevation of the object with respect to the camera, if desired, can be calculated from the angular measurements previously described.

The procedure. for making stereophotographs of landscapes with a short bar requires only that the bar be designed such that a camera can be placed level on the bar and aimed at the same subject from two adjacent positions-for instance, two places at a known distance along the bar. With the bar mounted on a tripod, a mark is made on the ground below the camera lens when the camera is located at a middle position on the bar, thus marking the site of the stereophotograph. Various devices that can be modified for stereophotography 

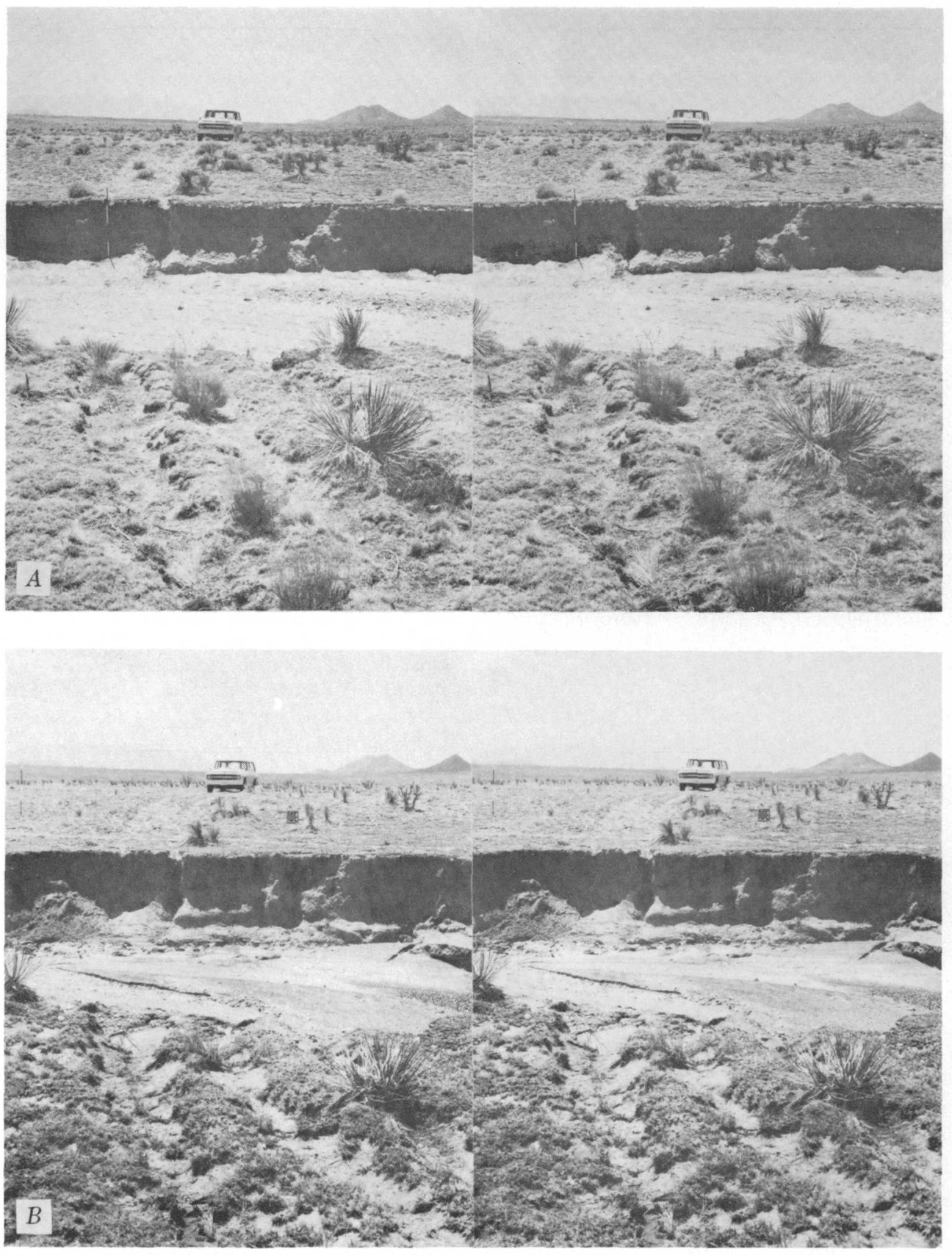

Figure 10.

are sold by the makers of photographic equipment, but a bar specifically designed for a particular camera must generally be made in an instrument shop. The horizontal movements of a view camera, which permit the camera axis to be shifted from side to side, can also be used for stereophotography.

Those who see a stereophotograph of a landscape for the first time are impressed by its startling realism, and they usually misjudge the separation of the paired photographs that create the enhanced perception of depth. Even experienced users of stereophotographs of other kinds often mistakenly think that the separation between a typical stereopair of a landscape is at least 1 foot. On the contrary, a separation of 1 foot would produce an image of a landscape that cannot be viewed stereoscopically in its entirety from front to back, although the near and far areas can be viewed individually. In theory, the separation should be the distance between the eyes, which amounts to about $6.4 \mathrm{~cm}$ for most people. However, in actual practice, a separation of $8 \mathrm{~cm}$ between the paired photographs of a landscape, taken from the ground, forms a slightly exaggerated image that can still be viewed comfortably. Such stereophotographs can be studied as enlargements with the aid of a mirror stereoscope, or they can be printed side by side at a separation of $6.4 \mathrm{~cm}$ for viewing with either a pocket stereoscope or the unaided eyes. An example of repeated landscape photography by stereopairs is illustrated by figure 10 . 
Figure 10.-Stereophotographs of an area before and after a flood in New Mexico.

A. A former road breached by the arroyo of Pueblo Canion, 12 miles south-southwest of Santa Fe, N. Mex. Since the road was last used, which was surely within the present century, the arroyo has cut headward 573 feet. This stereopair was made on July 3 , 1971, at 1338 hours mountain daylight time. The arroyo was then 50 feet wide and 6.7 feet deep along the opposite bank. The two photographs of this pair were made at a separation of 8 $\mathrm{cm}$ and a height of $2 \mathrm{~m}$, using a lens of 213-mm focal length and 4- by 5 -inch stable film. The camera was level, but the lens was lowered $35 \mathrm{~mm}$ with respect to the center of the focal plane to increase the foreground area. The center of view bears $\mathrm{S} .57^{\circ} \mathrm{W}$. (Malde photograph 627 in field records of U.S. Geological Survey, Denver, Colo.)

B. Duplicate of Malde photograph 627 (fig. 10A), taken August 1, 1971, at 1336 hours mountain daylight time. A few days earlier, on July 26 , the arroyo overflowed as a result of heavy rain. This flood had a calculated discharge of 5,000 cubic feet per second for a period of less than half an hour. The arroyo cut headward an additional 34 feet, and the channel was deepened as much as 2 feet. Although bank erosion as a consequence of this flood was typically unmeasurable along the length of the arroyo, the near bank at this place was cut back several feet. (Malde photograph 685 in field records of U.S. Geological Survey, Denver, Colo.)

Stereophotographs of landscapes can also be used to measure the approximate distances to nearby objects, even though their main use is for improved visual realism. The distances are calculated from measurements on the paired photographs, as previously described. Because the base line is short, the measurements on the photographs are best done with a precise comparator. For example, if a stereopair is made with a $150-\mathrm{mm}$ lens from a base line $8 \mathrm{~cm}$ long, assuming a measurement error of $0.1 \mathrm{~mm}$ on the photographs, the distance to an object $12 \mathrm{~m}$ away can be determined with an error of 10 percent.

When greater accuracy is required in the measurement of distances by stereophotography, a procedure must be devised to make an accurate stereopair from the ends of a longer base line. Such a procedure might be needed, for instance, to measure the intricate changes in a landscape vulnerable to erosion, or to monitor the changing quality of a landscape under the impact of new forms of land use. Fortunately, the procedure for making stereophotographs from a base line requires only that the camera be placed level at the two ends and be aimed in a direction perpendicular to the base line. I will describe the simple steps that can be used with short and long base lines and then discuss the consequences of an error in the aiming point.

The simplest procedure for making an accurate stereopair from a base line makes use of a well-defined object at a considerable distance, preferably a distance several hundred times the selected length of the base line. The procedure requires some means for aiming the camera so that the distant object lies along a vertical line through the center of the field of view. If the camera lacks a focusing screen with a central mark, some other method of aiming it usually can be improvised, such as an open-sight alidade held against one side. The direction to the aiming point is first read with a compass, and the base line is laid out at right angles. Alternatively, the line of sight to the aiming point can be marked on the ground, and the perpendicular direction of the base line can then be located by ground measurements of the familiar 3-4-5 right triangle. With the direction of the base line established, photographs are made from two places along it, with the camera placed level and aimed at the distant object. Marks made with a plumb bob at the two positions give the length of the base line. The camera at these positions should be approximately at the same height, but small differences in height have no effect on the measurements that can be made from the photographs. Also, as I explain below, . the slight amount of convergence that results from this procedure can be ignored. With a liftle practice, these steps can be completed in 30 minutes. An example of a stereopair made by this method is given in figure 11 .

If a distant aiming point perpendicular to the desired base line cannot be found, or if the base line is very long, a second procedure for orienting the camera can be used. In this procedure, the base line itself is oriented toward a distant object-a circumstance that can be an advantage if stereophotographs are to be made in opposite directions from the base line. The procedure requires a device for alining the focal plane of the camera along the direction of the base line, aimed at the distant object. With the aid of this aiming device, the camera is thereby pointed at right angles to the base line. Photographs are made from two places, with the camera thus alined and placed level. As before, marks made with a plumb bob at these places define the length of the base line. The practical matters of alining the aiming device with the focal plane naturally differ among various types of cameras, and a satisfactory technique must be worked out individually for each one. This procedure for making stereophotographs from a base line is not quite as easy as the direct method of aiming the camera at a distant object, but the results are geometrically nearly the same. The choice -between these alternate procedures for simple stereophotography depends only on the character of the terrain that is being photographed.

Small errors in the aim of the camera have little practical effect on measurements that can be made with stereopairs. In figure 12 , for example, if the camera is averted $2^{\circ}$ from the aiming point, the image distance of an object at a field angle of $15^{\circ}$ would be shortened by one part in 1.00 . Fortunately, the error decreases with the field angle. Furthermore, a camera usually can be aimed much closer than $2^{\circ}$. If the error in the aiming point is half a degree, which amounts to pointing the camera with the accuracy of a Brunton compass, the error of measurement is only two parts in 1,000: Because of these small errors, stereopairs made by "convergent photography, whereby the camera is aimed slightly. inward from the two ends of a base line, are quite usable if optimumaccuracy is not required. 


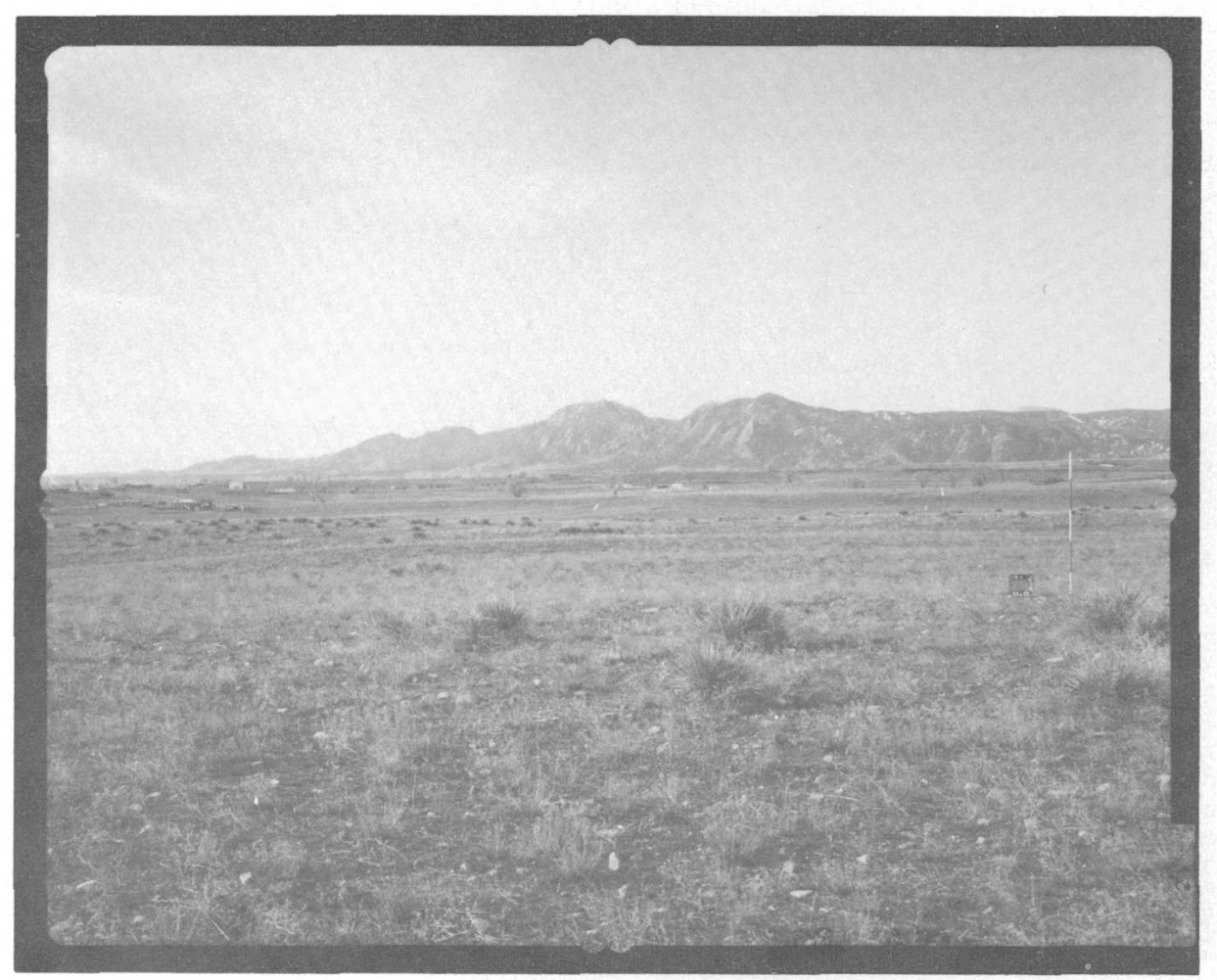

Figure 11.-A stereopair taken from a base line $14.91 \mathrm{~m}$ long oriented perpendicular to a line of sight to Bear Peak, a sharply pointed mountain in the foothills of the Front Range near Boulder, Colo. Bear Peak lies S. $21^{\circ} \mathrm{W}$. in the center of each photograph at a distance of $14 \mathrm{~km}$. This stereopair was made from a camera height of $1.6 \mathrm{~m}$ on February 29 , 1972, at about 0815 hours mountain standard time, using a lens of 150.6-mm focal length and 4- by 5-inch stable film. The fiducial marks at the edges were made with the metal slide described in the text. The measured distance from the base line to the ranging pole, which is marked in intervals of half a meter, is $23.34 \mathrm{~m}$. From measurements on the negatives, the distances from a central point to the image of the ranging pole are $47.94 \mathrm{~mm}$ and $48.14 \mathrm{~mm}$ on the right and left photographs, respectively. By the formula explained elsewhere in the text, the calculated distance on the ground to the ranging pole is $23.37 \mathrm{~m}$, which amounts to an error of 0.13 percent at this distance. (Malde photographs 694 and 695 in field records of U.S. Geological Survey, Denver, Colo.) The stereoimage formed by this pair of photographs can be viewed with a mirror stereoscope.

\section{CONCLUSION}

Geologists of the past left behind innumerable photographs of their travels, which increase in value with each passing day. Meanwhile, photographic techniques have steadily improved over those used by early geologists, and further improvements surely lie ahead. Even so, the existing methods of photography have hardly yet been tapped by geologists for documenting the changing qualities of landscapes. With present techniques and equipment, the routine practice of marking the positions of photographs taken in the field, at times making them as stereopairs, would provide growing archives of geologic bench marks that would greatly benefit the future knowledge of geologic change.

\section{REFERENCES CITED}

Baars, D. L., and Molenaar, C. M., 1971, Geology of Canyonlands and Cataract Canyon: Four Corners Geol. Soc., 6th Field Conf.,
Cataract Canyon River Expedition, 1971, 99 p.

Bryant, Bruce, 1971, Movement measurements on two rock glaciers in the eastern Elk Mountains, Colorado, in Geological Survey Research 1971: U.S. Geol. Survey Prof. Paper 750-B, p. B108-B116.

Case, J. B., 1961, Glacier-mapping activities in the United States: Internat. Assoc. Sci. Hydrology Pub. 54, p. 359-365.

Curry, R. R., 1967a, Photography and stereophotography, in Field methods for the study of slope and fluvial processes-A contribution to the International Hydrological Decade: Rev. Géomorphologie Dynam., v. 17, no. 4, p. 174-175.

$1967 \mathrm{~b}$, On repeated photographs, in Field methods for the study of slope and fluvial processes-A contribution to the International Hydrological Decade: Rev. Géomorphologie Dynam., v. 17, no. 4, p. $175-176$.

Emmett, W. W., and Hadley, R. F., 1968, The Vigil Network-Pt. C, preservation and access of data: U.S. Geol. Survey Circ. 460-C, 21 p.

Harrison, A. E., 1960, Exploring glaciers with a camera: San Francisco, Calif., Sierra Club, 71 p.

Hastings, J. R., and Turner, R. M., 1965, The changing mile, an ecological study of vegetation change with time in the lower mile of an arid and semiarid region: Tucson, Ariz., Univ. Arizona Press, $317 \mathrm{p}$. 


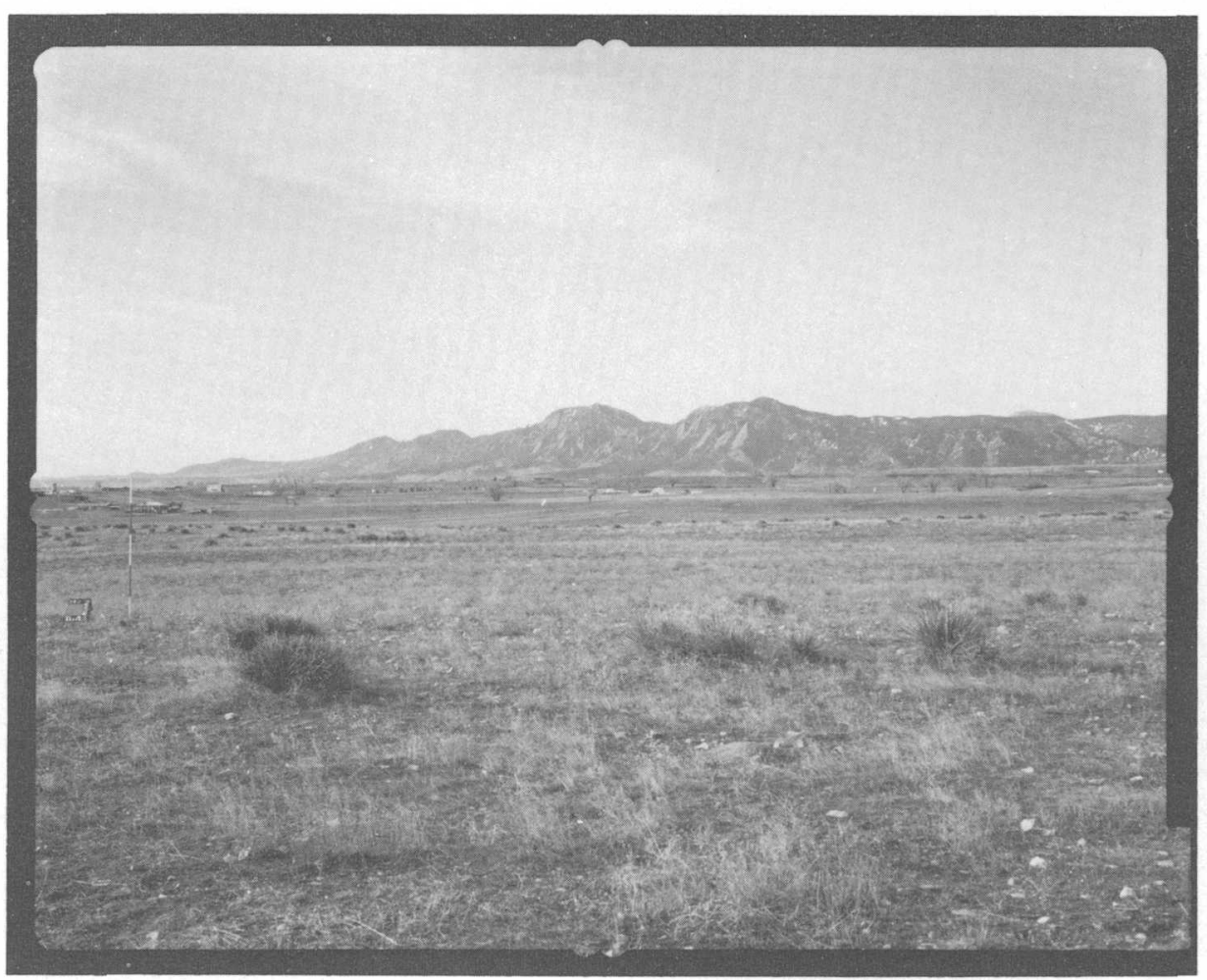

Figure 11.

Hattersley-Smith, G., 1966, The symposium on glacier mapping: Canadian Jour. Earth Sci., v. 3, no. 6, p. 737-743.

Janke, N. C., 1972, Field measurements with common equipment: Photogramm. Eng., v. 38, no. 1.,p. 37-47.

Konecny, Gottfried, 1966, Applications of photogrammetry to surveys of glaciers in Canada and Alaska, in Symposium on glacier mapping, Ottawa, 1965: Canadian Jour. Earth Sci., v. 3, no. 6, p. 783-798. Leopold, L. B., 1951, Vegetation of southwestern watersheds in the nineteenth century: Geog. Rev., v. 41, no. 2, p. 295-316.

Moseley, F., 1972, Stereoscopic ground photographs in field geology: Mercian Geologist, v. 4, no. 2, p. 97-99.

Phillips, W.S., 1963, Photographic documentation, vegetational changes in northern Great Plains: Arizona Univ., Agr. Experiment Sta. Rept. 214, 185 p.

Russell, I. C., 1898, Glaciers of Mount Rainier: U.S. Geol. Survey 18th Ann. Rept. 1896-97, pt. 2, p. 349-415.
Shepard, F. P., and Grant, U.S., 4th, 1947, Wave erosion along the southern California coast: Geol. Soc. America Bull., v. 58, no. 10, p. 919-926.

Strain, M. B., and Case, J. B., 1966, Terrestrial photogrammetry, in Thompson, M. M., and others, eds., Manual of photogrammetry, 3d ed., v. 2: Am. Soc. Photogrammetry, p. 919-959.

Veatch, F. M., 1969, Analysis of a 24-year photographic record of Nisqually Glacier, Mount Rainier National Park, Washington: U.S. Geol. Survey Prof. Paper 631, 52 p.

von Hagen, V. W., 1947, Maya explorer, John Lloyd Stephens and the lost cities of Central America and Yucatán: Norman, Okla., Univ. Oklahoma Press, 324 p.

Williams, J. C. C., 1969, Simple photogrammetry: London and New York, Academic Press, $211 \mathrm{p}$

Wolman, M. G., 1971, The nation's rivers: Science, v. 174, no. 4012, p. 905-918.

Note: Figure 12 is on the following page. 


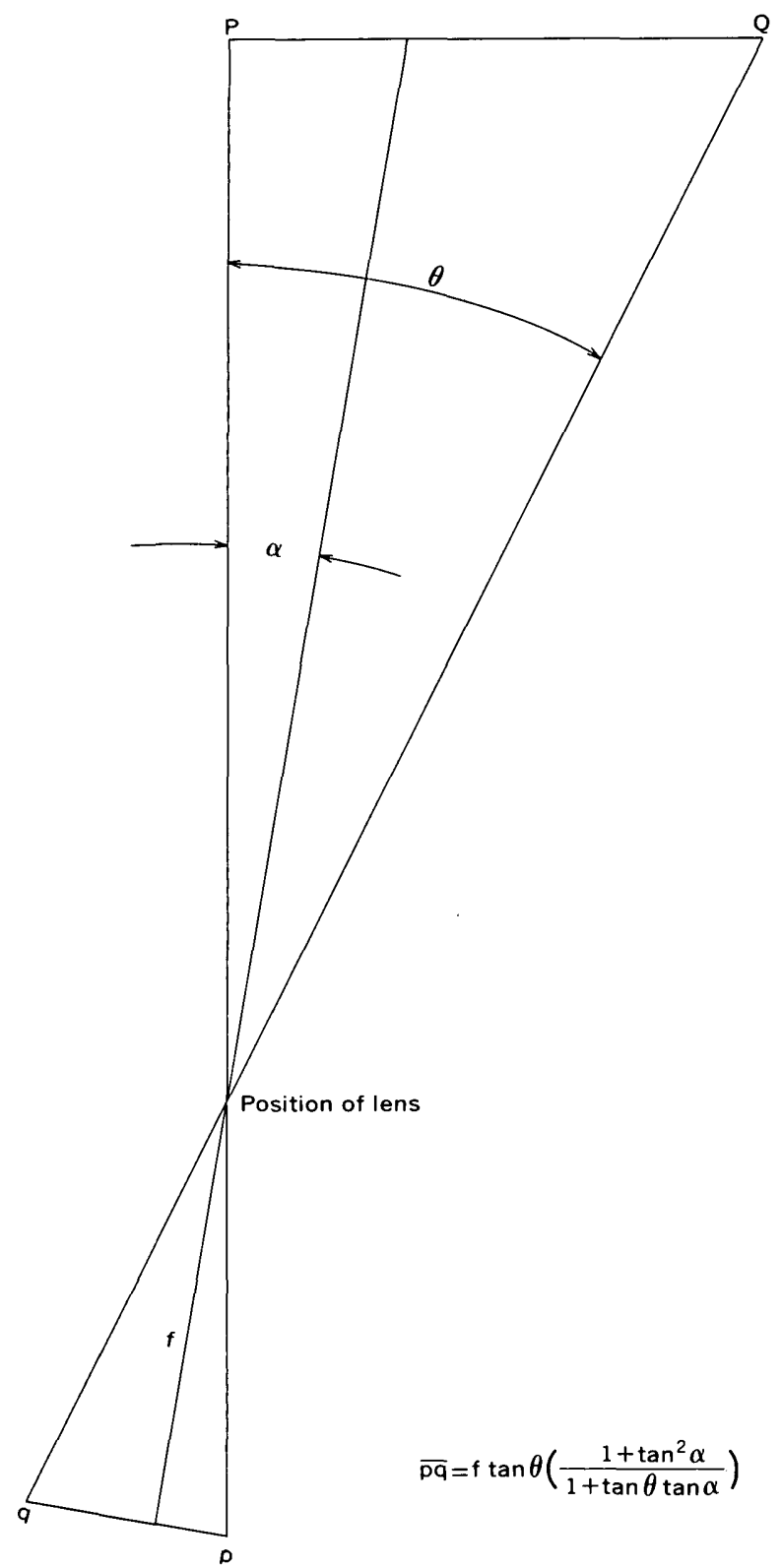

Figure 12.-Diagram of the geometry of a horizontal photograph made with a camera averted by a small angle, $\alpha$, from the nominal aiming point, $P$. The aiming point is pictured in the focal plane at $p$, and an object at $Q$ is pictured at $q$. If $f$ is the focal length, and if $\theta$ is the field angle between $P$ and $Q$, the distance in the focal plane between $p$ and $q$ is given by the indicated formula. This distance is slightly less than it would be if the camera were aimed directly at $P$, but the formula shows that small errors in the aiming point cause errors in the image that are too small for practical measurement. Even these errors are reduced when the field angle is small. 


\title{
THE MICROGRAVIMETRIC DETERMINATION OF ACID-INSOLUBLE IMPURITIES IN THE COMPLETE ANALYSIS OF SMALL SAMPLES OF ACID-SOLUBLE MINERALS
}

\author{
BY ROBERT MEYROWITZ, Washington, D.C.
}

\begin{abstract}
The acid-insoluble impurities of small samples of minerals are determined by a microgravimetric procedure. A Schwarz von Bergkampf glass filter stick with paper filter medium is used to separate the insoluble material. The filtration apparatus and procedural details are described.
\end{abstract}

Frequently, minerals contain impurities which cannot be separated mechanically. Data resulting from complete decomposition and chemical analysis of both the mineral and its contaminants cannot be used to calculate the correct molecular formula of the mineral, especially if the mineral is new and the mineral and its contaminants contain elements common to both. The following procedure is recommended for the separation and microgravimetric determination of acidinsoluble impurities in small samples of acid-soluble minerals.

The application of the Schwarz von Bergkampf (1930) filter stick in the analysis of small samples of minerals has been neglected in recent years. It provides an efficient technique for the collection of very small amounts of precipitate which require treatment with hydrofluoric acid or subsequent fusion.

\section{REAGENTS AND APPARATUS}

Sulfuric acid, $9 \mathrm{~N}$.

Sulfuric acid, $0.5 \mathrm{~N}$.

Filtration apparatus. Letters A-I identify apparatus shown in figure 1 .

(A) Crucible and cover (not shown), platinum, 15-ml capacity.

(B) Filter paper, low-ash; rolled into cylinder.

(C) Schwarz von Bergkampf (1930) filter stick; borosilicate-glass tubing with standard $0.8-\mathrm{mm}$ wall, $4-\mathrm{mm}$ outside diameter, and $80-$ to $90-\mathrm{mm}$ overall length. The center of the constriction is 10 to $13 \mathrm{~mm}$ from the end, and a 5 - to $6-\mathrm{mm}$ section of tubing of undiminished bore below the constriction provides for the placement of the paper cylinder.

(D) Tubing, microchemical, thin-wall rubber, $13 \mathrm{~mm}$ long.

(E) Siphon; borosilicate-glass capillary tubing with 5- to 6-mm outside diameter and 0.25 - to $0.75-\mathrm{mm}$ bore. The outside diameter of the curved end is 2 to $4 \mathrm{~mm}$ and that of other end is the same as that of the filter stick, namely $4 \mathrm{~mm}$.

(F) Stopper, rubber, one-hole.

(G) Bell jar, micro. Available from Corning Glass Works, Corning, N.Y., catalog No. 6880 (with ground glass plate) or from
Kimble Products by Owens-Illinois, Toledo, Ohio, catalog No. 32450 (without ground glass plate).

(H) Beaker, borosilicate-glass, 50-ml capacity.

(I) Plate, ground glass.

Plate, quartz; for bottom of furnace.

Tweezers, platinum-tipped.

Thermometer, surface-temperature, $0^{\circ}-540^{\circ} \mathrm{C}$.

Air bath, micro. This consists of a thermostatically controlled hotplate and a vented glass dome provided with an additional hole on top for insertion of a glass thermometer. (See Rulfs, 1951, p. 48, fig. 2.)

Cooling block, brass, chromium-plated.

Jack, positioner, laboratory.

Filter paper, low-ash, rectangular, 9 by $35 \mathrm{~mm}$ and 9 by $12 \mathrm{~mm}$.

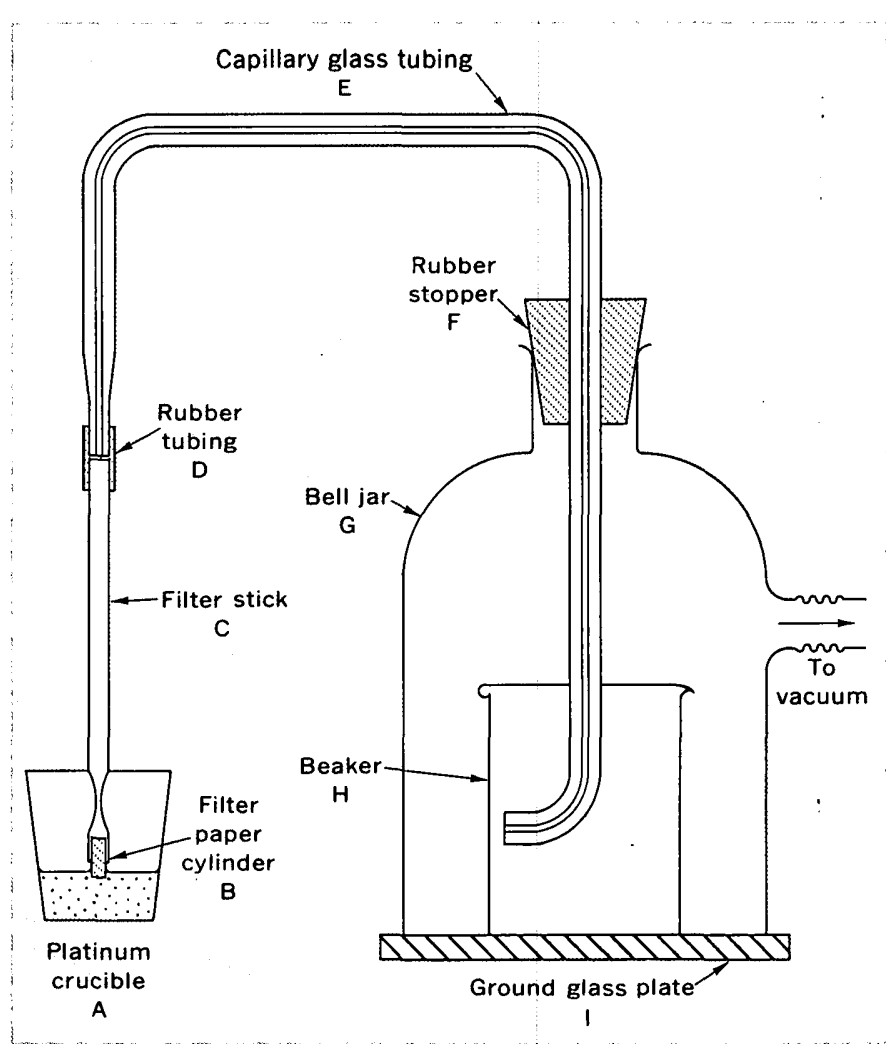

Figure 1.-Filtration apparatus. Description is given in text. 


\section{PROCEDURE}

1. Weigh a 20 - to $50-\mathrm{mg}( \pm 0.01 \mathrm{mg})$ sample in a $15-\mathrm{ml}$ platinum crucible (with cover) which has been ignited to constant weight $( \pm 0.02 \mathrm{mg})$ at $850^{\circ} \mathrm{C}$ in an electric furnace.

2. Place crucible (uncovered) and crucible cover in the air bath at $110^{\circ} \pm 5^{\circ} \mathrm{C}$ for 2 hours. Cover the crucible with cover, and cool in desiccator for 20 minutes. Weigh. Calculate the percentage of $\mathrm{H}_{2} \mathrm{O}$ lost.

3. Place crucible cover in desiccator or other clean and safe place until needed.

4. Add from a few drops to $1 \mathrm{ml}$ of water down the side of the crucible to moisten the sample of mineral. Add 4 $\mathrm{ml}$ of $9 \mathrm{~N} \mathrm{H}_{2} \mathrm{SO}_{4}$ slowly down the side of the crucible. Mix by gentle swirling.

5. Place in hot air bath (approximately $100^{\circ} \mathrm{C}$ ) for as long as it is necessary to decompose the mineral. Add water at necessary intervals to replace evaporated water.

6. Evaporate to first appearance of sulfuric acid fumes. Cool. Add $5.0 \mathrm{ml}$ of water and again evaporate to first appearance of sulfuric acid fumes. Cool.

7. Add $5.0 \mathrm{ml}$ of water and warm in hot air bath (approximately $100^{\circ} \mathrm{C}$ ) to dissolve soluble salts.

8. Prepare the filter stick by rolling a 9 - by $35-\mathrm{mm}$ piece of low-ash filter paper between the fingers into a tight cylinder and until the hole in the center disappears. If the cylinder does not fit in to the end of the filter stick, cut a small part off the loose end. Roll cylinder again until it is compact and then insert it into the filter stick when the proper thickness has been obtained. The paper cylinder projects approximately $3 \mathrm{~mm}$ beyond the end of the filter stick, the other end of which is attached to the siphon tube by means of a glass-to-glass butt connection.

Test the filter stick for the proper rate of filtration by moistening the paper cylinder with a few drops of water, connecting it to the siphon tube, and filtering distilled water. The paper cylinder swells when wetted. The water should come over dropwise at a steady rate. If no filtrate comes through, remove the cylinder, cut off a very small part of it, reinsert it in the filter stick, and test again. Replace the beaker containing the distilled water filtrate with an empty beaker before the sample is filtered.

9. Position the crucible on a laboratory jack so that the paper cylinder of the filter stick just dips into the solution. Apply suction slowly and increase suction until there is a slow dropwise but steady filtration. As the filtration proceeds, raise the laboratory jack to keep pace with the lowering surface of the solution, taking care to see that the paper cylinder just dips into the solution.

10. Raise the crucible at the last stages of filtration so that the filter stick touches the bottom of the crucible to draw off the liquid as completely as possible. While the head of the filter stick is still touching the bottom of the crucible and the suction is still on, rinse down the lower part of the filter stick with $1.0 \mathrm{ml}$ of $0.5 \mathrm{~N}$ $\mathrm{H}_{2} \mathrm{SO}_{4}$.

11. Lower the crucible from the filter stick after the wash solution has been drawn off and suction is still on, and rotate the crucible in an inclined position while $2.0 \mathrm{ml}$ of $0.5 \mathrm{~N} \mathrm{H}_{2} \mathrm{SO}_{4}$ is added dropwise down its side. Rerinse the entire inside of the crucible at least once while rotating the crucible in an inclined position. Warm in the hot air bath for 2 minutes. Filter off the liquid as described in step 9.

12. Repeat step 11 three times.

13. Hold the filter stick over the crucible and, using the platinum-tipped tweezers, remove the paper cylinder from the filter stick and drop it into the crucible.

14. Pick up a small rectangular piece of filter paper and moisten it slightly with water. Use it to wipe the opening and outside bottom of the filter stick to remove any silicic acid present and drop it into the crucible.

15. Use a second piece of moistened filter paper to wipe the platinum tips of the tweezers and drop it into the crucible.

16. Place the crucible in a hot air bath (approximately $100^{\circ} \mathrm{C}$ ) to remove water and then place it on a clean surface on a hotplate (surface temperature approximately $100^{\circ} \mathrm{C}$ ). Raise the temperature of the hotplate slowly to $270^{\circ} \mathrm{C}$ to remove all the $\mathrm{H}_{2} \mathrm{SO}_{4}$.

17. Cover the crucible with a cover and place in an electric furnace at room temperature. Set the controller at $550^{\circ} \mathrm{C}$. When this temperature has been reached, remove crucible from furnace, place on the cooling block, and allow to cool to room temperature. If all the carbon has not burned off, again place crucible in the furnace and heat until all the carbon has been removed. Set controller at $850^{\circ} \mathrm{C}$. When the temperature has reached $850^{\circ} \mathrm{C}$, place crucible in the furnace for 10 minutes, remove from furnace, place in a desiccator for 30 minutes, and weigh. Weigh to constant weight $( \pm 0.02 \mathrm{mg})$.

18. Calculate the percentage of acid-insoluble material.

\section{DISCUSSION}

Silica present either as an impurity of soluble silica or as silica in an acid-soluble silicate will dissolve in the acid. The decomposition mixture is brought to fumes of sulfuric acid to render the silica insoluble for filtration with the other insoluble material. The procedure describes the use of sulfuric acid because it is the acid most likely to be used. However, other acids can be used if they are suitable. Sulfuric acid is relatively inert except primarily in the presence of barium, strontium, or lead, which precludes its use. The presence of 
silver precludes the use of hydrochloric acid, and the presence of chloride precludes the use of nitric acid if a platinum crucible is to be used. The presence of oxidizing agents such as manganese dioxide, ferric iron, nitrate, and vanadate also obviates the use of hydrochloric acid if a platinum crucible is to be used. The filtrate collected in the $50-\mathrm{ml}$ beaker is used for the analysis of the remainder of the sample. The procedures used for these analyses often require that a particular anion be absent. All of these considerations must be dovetailed in the selection of the dissolving acid.

Sometimes it is necessary to boil the sample (step 5) in order to dissolve the mineral. The correction for the ash content of the filter paper is negligible. It is assumed that there is no loss in weight on ignition of the insoluble material other than nonessential water and that an insignificant amount of water will remain with any solubilized and subsequently precipitated silica. The nature of the insoluble material may be determined by microscopic examination, qualitative microspectrographic analysis, and X-ray diffraction.

This type of filter stick was first described by Schwarz von Bergkampf (1930) and used by others, especially BenedettiPichler (1942, p. 198-221). Both ends are cut on the square and are carefully fire-polished so that the ends remain flat and the bore at the ends is not reduced. If the bore at the lower end of the filterstick becomes reduced, there will be a vacant space between the paper cylinder and the inside wall of the filter stick. The ends of the siphon tube are also cut on the square. The diameter of the end which is attached to the filter stick by the small piece of rubber tubing is reduced to match that of the filter stick in order to minimize the amount of filtrate that might be caught in the space between the two tubes.

The end of the siphon tube is drawn out to make the drops of falling filtrate small, and it is curved to direct the filtrate against the side of the beaker rather than the surface of the filtrate to prevent loss by spattering.

\section{REFERENCES CITED}

Benedetti-Pichler, A. A., 1942, Introduction to the microtechnique of inorganic analysis: New York, John Wiley and Son's, $302 \mathrm{p}$.'

Rulfs, C. L., 1951, Quantitative semimicro inorganic procedures: Anal. Chim. Acta, v. 5, p. 46-54.

Schwarz von Bergkampf, Erich, 1930, Eine neue anwendung der filterstabchen: Mikrochemie, Friedrich Emich Festschrift, p. $269-274$. 


\section{-}




\title{
EFFECTS OF LABORATORY TREATMENTS ON SILVER AND OTHER ELEMENTS IN NATIVE GOLD
}

\author{
BY W. L. CAMPBELL, E. L. MOSIER, \\ and J. C. ANTWEILER, Denver, Colo.
}

\begin{abstract}
Interpretation of the element content of gold and of alloy proportions of gold and silver may have useful applications in prospecting and ore genesis studies. The commonly used methods of concentration and recovery of gold for analysis (acid leach, roasting, or amalgamation), however, alter the content of silver and other elements in the gold. The treatment of gold with four mineral acids (HF, HCL, $\mathrm{H}_{2} \mathrm{SO}_{4}$, and $\mathrm{HNO}_{3}$ ) and combinations of these acids, amalgamation of the gold, and roasting the gold in a muffle furnace at $650^{\circ} \mathrm{C}$ for 8 hours caused losses of 0-100 percent of the elements studied. In some of the samples studied these treatments also caused losses totaling as much as 50 percent, by weight, of the silver content (which made up 20 percent of the total sample weight). The other elements studied show similar behavior to a lesser extent. The results of these studies show that before one interprets compositional analyses for prospecting or other applications he must know to what extent a recovery treatment changes the composition of the elements.
\end{abstract}

Gold from various types of ore deposits has diagnostic compositional features consisting of variations in the content of elements present in trace amounts in the gold and alloy proportions of gold and silver (Antweiler and Sutton, 1970, p. 11-15). Interpretation of gold compositional data may, therefore, have useful application in prospecting and ore genesis studies. Gold occurs not only in placer deposits, but also in a great variety of lode deposits, in some as the most economically important metal, but in most as a minor constituent. The potential prospecting application of gold compositional data may therefore be extensive. The methods commonly used to concentrate and recover gold (treatment by $\mathrm{HF}, \mathrm{HCl}, \mathrm{H}_{2} \mathrm{SO}_{4}$, and $\mathrm{HNO}_{3}$; amalgamation; and roasting) may alter the elemental content of the gold to the extent that the original compositional characteristics of the gold cannot be determined. The purpose of this paper is to show the amount of change in the content of silver and other elements in gold recovered by the different laboratory procedures.

\section{COMMON METHODS OF GOLD CONCENTRATION AND RECOVERY}

Gravity concentration methods including careful panning followed by handpicking under a microscope are satisfactory for recovering gold for analysis from placer deposits or free-milling or oxidized ores. Gold particles as small as $75 \mu$ in diameter can be recovered in this way, but repeated panning and patience are necessary to recover the small particles. Alternatively, gold particles can be separated from other heavy minerals by adding a small quantity of mercury to amalgamate the gold. Contact of clean mercury with clean gold particles effectively segregates gold from all the other heavy minerals. Gold can be recovered from the mercury amalgam either by solution of mercury with nitric acid, by driving off mercury with heat, by filtration, or by freezing. An obvious disadvantage of amalgamation is that the natural mercury content of the samples cannot be determined.

Procedures for obtaining gold from sulfides or tellurides are necessarily more complex than those used for obtaining free gold. Several acid-leaching and roasting procedures can be used, either alone or in combination with one another. Preconcentration by panning is usually done to remove lighter minerals. In general, if pyrite or arsenopyrite are dominant minerals, the sample is roasted at $650^{\circ} \mathrm{C}$. If galena or chalcopyrite are dominant minerals, a nitric acid leach effectively removes them. If gold is intimately associated with quartz, and is not released by coarse grinding of the sample, a hydrofluoric acid leach usually removes the quartz. Iron-rich minerals such as limonite can be removed by hydrochloric acid. If tellurides are dominant minerals, one must decide whether to recover and analyze the tellurides, or destroy them by roasting or with acids to recover and analyze only the gold. After any acid-leaching or roasting procedure, final cleanup of gold particles must be done by amalgamation or by handpicking the gold.

\section{LABORATORY STUDIES}

This study was prompted in part by our observations that tiny gold grains, when recovered by acid leaching of ore material, showed a marked decrease in silver near the edges, as determined by electron-beam microprobe analyses. In contrast, silver-depleted edges were not detected in grains obtained simply by panning oxidized ore. Further tests suggested 
that for these tiny gold grains even mild acid cleaning prior to spectrographic analysis created a bias in the analytical results through loss of silver and other elements. Obviously, loss of silver and other elements would be easier to observe on small-particle gold than on nuggets because the percentage of gold exposed to surface contact increases with decreasing particle size. To minimize that variation for this study, samples of uniform size were used for nugget gold and random splits were used for lode gold.

To study the effects of the concentration and recovery treatments on gold composition, replicate analyses were made on treated and untreated native gold from two localities: lode gold from the Seafoam mine, Custer County, Idaho (Ross, 1930 , p. 3), and placer nugget gold from the Apache Oro mine, Lost Basin, Mohave County, Ariz. Both the lode and nugget gold samples were split into fractions, and the fractions were subjected to various acid-leaching procedures. The lode samples were also subjected to amalgamation and roasting procedures. The laboratory treatments and changes in element content in the gold samples are discussed in detail in the following section.

\section{LABORATORY TREATMENTS USED}

Sericitized and oxidized vein material from the Seafoam mine was ground to pass a 35 -mesh screen and panned to remove gangue minerals and sulfides. Finely divided free gold particles left in the pan $(75 \mu-100 \mu$ in diameter) were then recovered by handpicking under a binocular microscope. The gold was then randomly split into 11 fractions of approximately $25 \mathrm{mg}$ each.

A nugget (approximately $10 \mathrm{~mm}$ in diameter) from the Apache Oro mine was cut into 45 fractions weighing approximately $5 \mathrm{mg}$ each.

1. The following acids and acid combinations were used for leaching the gold for testing:

On lode and placer samples (five splits used for each leach):

1:1 hydrofluoric acid:distilled water

1:1 hydrochloric acid:distilled water

1:1 sulfuric acid:distilled water

$1: 1$ nitric acid:distilled water

1:1:1 hydrofluoric acid:hydrochloric acid:distilled water

1:1:1 hydrofluoric acid:nitric acid:distilled water

On lode samples only (five splits used for each leach):

1:1:1 hydrofluoric acid:sulfuric acid:distilled water

1:1:1 hydrochloric acid:sulfuric acid:distilled water

All samples were leached at about $85^{\circ} \mathrm{C}$ for 24 hours on a steam bath. Because of the limited amount of nugget gold available, only the first six acid solutions were used. After leaching, the samples were washed four times with distilled water and dried prior to analysis.

2. Roasting (five splits of the lode and placer sample were roasted):
The splits were roasted in a muffle furnace for 8 hours at $650^{\circ} \mathrm{C}$ to simulate the temperature effect that would be produced by roasting a gold-rich pyrite sample long enough to oxidize the pyrite.

3. Amalgamation (five splits of the lode sample were amalgamated):

The splits were amalgamated with triple-mercury, and gold was recovered by digesting the amalgam with $1: 1$ nitric acid-distilled water. The splits were then rinsed with distilled water, and dried prior to analysis.

\section{ANALYSIS}

A direct-arc six-step semiquantitative spectrographic method, designed for $5 \mathrm{mg}$ or less (E. L. Mosier, unpub. data, 1972), was used to analyze the samples for silver and other elements. Five replicate analyses were made on raw gold from the Seafoam mine and on each treated fraction except that only two were made on the fraction treated with hydrochloricsulfuric acid. Fifteen replicate analyses were made on raw gold from the nugget, and five replicate analyses on each treated fraction. Approximately $5 \mathrm{mg}$ was used for most of the analyses, but the actual weight, which was governed by the size of the particles and the amount available, ranged from 2.5 to $6 \mathrm{mg}$.

A small amount of the lode gold was analyzed for silver variations by electron-beam microprobe by use of the method and standards described by Desborough (1970). Because the concentration of all other elements was less than the lower limit of detection, no other elements could be determined by this method.

\section{RESULTS OF SPECTROGRAPHIC ANALYSES}

The results of spectrographic analyses are shown in tables $]$ and 2. The analyses of untreated gold serve as a point of reference to determine the effects of the various procedures on the content of silver and the other elements in the treated gold. The results indicate that the element content of gold is altered by recovery procedures.

The detection of $\mathrm{Ba}, \mathrm{B}, \mathrm{Cr}, \mathrm{Mn}, \mathrm{Mo}, \mathrm{Ni}, \mathrm{Pt}, \mathrm{W}$, and $\mathrm{Zr}$ in some analyses but not in others suggests that these elements probably occur in discrete mineral impurities rather than as alloy lattice components. This characteristic dramatically illustrates the heterogeneity not only among lode gold grains deposited close to one another in a vein, but also within a single gold nugget. The irregular occurrences of these elements in the gold make interpretations of the analytical data difficult and suggest that a single analysis may have little value in determining the elemental composition of gold.

A somewhat different trace element assemblage occurs in gold from the two localities. The Lost Basin placer gold contains traces of chromium, tungsten, vanadium, and zirconium-none of which were detected in the Seafoam lode gold-and contains slightly more magnesium, manganese, 
Table 1.-Direct-arc six-step spectrographic analyses of placer nugget gold from Lost Basin, Mohave County, Ariz.

[Values for silver are in percent and are quantitative; other elements are in parts per million and are semiquantitative. Number in parentheses indicates sensitivity of method for $5-\mathrm{mg}$ sample. Symbols: L, element was detected but in an amount below the sensitivity limits; $\mathrm{N}$, element was looked for but not found. Also looked for but not found: $\mathrm{As}(50), \mathrm{Te}(50), \mathrm{Mn}(5), \mathrm{La}(20), \mathrm{Ta}(500), \mathrm{Be}(1), \mathrm{Sb}(10)$, $\operatorname{Pt}(10), \operatorname{Pd}(5), \mathrm{Zn}(50), \mathrm{V}(5), \operatorname{Zr}(10), \mathrm{Ni}(10), \operatorname{Cd}(10), \mathrm{B}(2), \mathrm{Y}(2), \operatorname{Mo}(10), \operatorname{Sn}(5), \operatorname{Co}(5), \mathrm{W}(50), \mathrm{Nb}(10), \operatorname{Sc}(2), \operatorname{Cr}(5), \operatorname{Ba}(10), \operatorname{Sr}(50)$, In(5), $\mathrm{Ga}(5), \mathrm{Ge}(5)$. "Other elements" column, occasionally detected elements-not frequent enough for statistical study]

\begin{tabular}{|c|c|c|c|c|c|c|c|c|c|c|c|c|}
\hline Treatment & $\begin{array}{c}\mathrm{Ag} \\
(0.0001)\end{array}$ & $\mathrm{Cu}(1)$ & $\mathrm{Hg}(50)$ & $\mathrm{Pb}(1)$ & $\mathrm{Bi}(1)$ & $\operatorname{Mn}(5)$ & $\mathrm{Fe}(10)$ & $\mathrm{Ca}(10)$ & $\operatorname{Mg}(5)$ & $\mathrm{Ti}(5)$ & $\mathrm{Si}(10)$ & $\begin{array}{l}\text { Other } \\
\text { elements }\end{array}$ \\
\hline \multirow[t]{15}{*}{ 1. Untreated } & 10.0 & 200 & 2,000 & 700 & $\mathbf{N}$ & 10 & 500 & 15 & 50 & $\mathrm{~N}$ & 2,000 & B \\
\hline & $2 \ldots 15.0$ & 200 & 2,000 & 500 & $\mathrm{~N}$ & 15 & 1,000 & 30 & 200 & $\mathrm{~N}$ & 2,000 & B \\
\hline & $3 . \ldots 10.0$ & 150 & 1,500 & 200 & $\mathrm{~N}$ & 10 & 700 & 15 & 200 & $\mathrm{~N}$ & 2,000 & B \\
\hline & $4 \ldots 10.0$ & 200 & 1,000 & 500 & $\mathrm{~N}$ & 7 & 300 & 20 & 200 & 100 & 1,500 & B \\
\hline & $5 \ldots 15.0$ & 150 & 1,500 & 500 & $\mathrm{~N}$ & 10 & 700 & 15 & 150 & 10 & 5,000 & B \\
\hline & $6 . \ldots 15.0$ & 500 & 2,000 & 100 & 15 & 10 & 500 & 30 & 200 & 50 & 7,000 & B \\
\hline & $7 \ldots 10.0$ & 200 & 100 & 1,000 & 10 & 5 & 500 & 15 & 200 & 70 & 500 & \\
\hline & 8. . 10.0 & 200 & 2,000 & 150 & 2 & 5 & 200 & 70 & 50 & 100 & 1,000 & \\
\hline & $9 . \ldots 10.0$ & 150 & 1,500 & 30 & 10 & 7 & 500 & 200 & 100 & 50 & 1,500 & B \\
\hline & $10 \ldots 10.0$ & 200 & 1,000 & 100 & 10 & 5 & 150 & 50 & 150 & 100 & 1,500 & \\
\hline & 11. ... 4.2 & 150 & 200 & 20 & 3 & 1.5 & 30 & 50 & 100 & 70 & 1,500 & B \\
\hline & $12 \ldots 10.0$ & 100 & 300 & 2 & 3 & 7 & 700 & 100 & 30 & 5 & 3,000 & \\
\hline & $13 \ldots \quad 2.5$ & 300 & 500 & 5 & 2 & 10 & 70 & 50 & 100 & 20 & $\mathrm{~N}$ & \\
\hline & $14 \ldots .9 .9$ & 150 & 300 & 50 & 1.5 & 2 & $\mathrm{~N}$ & 50 & 30 & 70 & 2,000 & V \\
\hline & $15 \ldots \quad 9.5$ & 10 & 300 & 30 & 2 & $\mathrm{~N}$ & 50 & 20 & 150 & 20 & 300 & B \\
\hline Mean (M).... & $\ldots \ldots 10.0$ & 191 & 1,080 & 259 & 3.9 & 7 & 393 & 49 & 127 & 44 & 2,050 & \\
\hline \multicolumn{13}{|l|}{ Standard devia- } \\
\hline tion (d) $\ldots$ & 3.4 & 106 & 748 & 307 & 4.8 & 4 & 305 & 49 & 66 & 39 & 1,800 & \\
\hline \multirow[t]{7}{*}{ 2. $\mathrm{HF}+\mathrm{H}_{2} \mathrm{O}$} & $1 . \ldots 10.0$ & 150 & 1,000 & $\mathrm{~N}$ & $\mathrm{~N}$ & $\mathrm{~N}$ & 5 & 7 & 3 & $\mathrm{~N}$ & 10 & \\
\hline & $2 \ldots 16.7$ & 300 & 700 & 15 & $\mathrm{~N}$ & 1.5 & 30 & 50 & 20 & $\mathrm{~N}$ & 30 & \\
\hline & $3 . \ldots 6.3$ & 70 & 300 & 5 & $\mathrm{~N}$ & $\mathrm{~N}$ & 10 & 10 & 5 & $\mathrm{~N}$ & 300 & \\
\hline & $4 . \ldots \quad 9.5$ & 200 & 5,000 & 2 & $\mathrm{~N}$ & 3 & 200 & 100 & 50 & $\mathbf{N}$ & 500 & \\
\hline & $5 \ldots$ & 3 & 150 & 3 & $\mathrm{~N}$ & $\mathbf{N}$ & $\mathbf{N}$ & 30 & 15 & 50 & 30 & \\
\hline & M. . 8.6 & 145 & 1,430 & 5 & $\ldots$ & .9 & 49 & 39 & 19 & 10 & 174 & \\
\hline & d. ... 5.8 & 115 & 2,023 & 6 & $\ldots$ & 1.3 & 85 & 38 & 19 & 22 & 218 & \\
\hline \multirow[t]{7}{*}{ 3. $\mathrm{HCl}+\mathrm{H}_{2} \mathrm{O}$} & $1 \ldots \quad 3.8$ & 10 & 200 & 2 & $\mathrm{~N}$ & $\mathrm{~N}$ & $\mathrm{~N}$ & $\mathrm{~L}(20)$ & 10 & $\mathrm{~N}$ & 1,000 & \\
\hline & $2 \ldots \quad 6.0$ & 70 & 300 & 3 & $\mathrm{~N}$ & $\mathrm{~N}$ & $\mathrm{~N}$ & 20 & 10 & $\mathrm{~N}$ & 200 & \\
\hline & $3 . \ldots 4.2$ & 70 & 1,000 & 1 & $\mathrm{~N}$ & $\mathrm{~N}$ & 9 & 10 & 7 & $\mathrm{~N}$ & 300 & \\
\hline & $4 . \ldots 4.8$ & 50 & 150 & 1.5 & $\mathrm{~N}$ & $\mathbf{N}$ & 15 & 15 & 7 & $\mathrm{~N}$ & 300 & Mo, W \\
\hline & $5 . \ldots 5.1$ & 70 & 300 & 1.5 & $\mathrm{~N}$ & $\mathrm{~N}$ & 15 & 15 & 7 & $\mathrm{~N}$ & 500 & Mo, $\mathrm{Ni}$ \\
\hline & M.. 4.8 & 54 & 390 & 1.8 & $\ldots$ & $\ldots$ & 7.8 & $L(16)$ & 8.2 & $\ldots$ & 460 & \\
\hline & $\begin{array}{ll}\text { d. } \ldots . .8 & .8\end{array}$ & 26 & 347 & .8 & $\ldots$ & $\ldots$ & 7.5 & 4 & 1.6 & $\ldots$ & 320 & \\
\hline \multirow[t]{7}{*}{ 4. $\mathrm{H}_{2} \mathrm{SO}_{4}+\mathrm{H}_{2} \mathrm{O}$} & $1 . \ldots 6.0$ & 70 & 300 & $\mathrm{~N}$ & $\mathrm{~N}$ & $\mathbf{L}$ & 15 & 10 & 50 & $\mathrm{~N}$ & 700 & \\
\hline & $2 \ldots \quad 5.8$ & 70 & 500 & $\mathrm{~N}$ & $\mathrm{~N}$ & $\mathbf{N}$ & 15 & 10 & 5 & $\mathrm{~N}$ & 200 & \\
\hline & $3 . \ldots 7.0$ & 100 & 200 & 2 & $\mathrm{~N}$ & $\mathbf{L}$ & 50 & 15 & 20 & $\mathrm{~N}$ & 3,000 & Mo, $\mathrm{Zr}$ \\
\hline & $4 . \ldots 15.0$ & 150 & 500 & 1.5 & $\mathrm{~N}$ & 1.5 & 15 & 15 & 20 & 100 & 1,500 & \\
\hline & $5 . \ldots 7.0$ & 100 & 200 & 1 & $\mathrm{~N}$ & $\mathrm{~N}$ & $\mathbf{N}$ & 10 & 10 & 5 & 500 & \\
\hline & M... 8.2 & 98 & 340 & .9 & $\ldots$ & .3 & 19 & 12 & 21 & 21 & 1,180 & \\
\hline & d. ... 3.9 & 33 & 150 & .9 & $\ldots$ & .7 & 18.5 & 2.7 & 11 & 44 & 1,125 & \\
\hline \multirow[t]{7}{*}{ 5. $\mathrm{HNO}_{3}+\mathrm{H}_{2} \mathrm{O}$} & $1 \ldots \quad 7.0$ & 100 & 500 & 1 & $\mathrm{~N}$ & 1 & 30 & 10 & 10 & $\mathrm{~N}$ & 500 & \\
\hline & $2 \ldots 12.0$ & 150 & 300 & 1 & $\mathrm{~N}$ & 1 & 30 & 10 & 15 & $\mathbf{N}$ & 1,500 & $\mathrm{Cr}, \mathrm{Ni}$ \\
\hline & $3 . \ldots 8.1$ & 100 & 500 & $\mathrm{~N}$ & $\mathrm{~N}$ & $\mathrm{~N}$ & 5 & 10 & 5 & $\mathrm{~N}$ & 20 & \\
\hline & $4 \ldots \quad 4.5$ & 30 & 500 & 1.5 & $\mathbf{N}$ & $\mathrm{N}$ & 15 & 15 & 10 & $\mathrm{~N}$ & 300 & \\
\hline & $5 \ldots \quad 3.6$ & 20 & 200 & 3 & $\mathbf{N}$ & $\mathrm{N}$ & $\mathrm{N}$ & 30 & 20 & 100 & 2,000 & \\
\hline & M... 7.0 & 80 & 400 & 1.3 & $\ldots$ & .4 & 16 & 15 & 12 & 20 & 860 & \\
\hline & d. ... 3.3 & 54 & 140 & 1.1 & $\ldots$ & .5 & 14 & 8.7 & 6 & 45 & 845 & \\
\hline \multirow[t]{7}{*}{ 6. $\mathrm{HF}+\mathrm{HCl}+\mathrm{H}_{2} \mathrm{O}$} & $1 \ldots$ & 1.5 & 150 & 1.5 & $\mathrm{~N}$ & $\mathrm{~N}$ & $\mathbf{N}$ & 15 & 7 & $\mathrm{~N}$ & 15 & \\
\hline & $2 \ldots \quad 2.0$ & 10 & 300 & $\mathrm{~N}$ & $\mathrm{~N}$ & $\mathrm{~N}$ & 7 & 15 & 7 & $\mathbf{N}$ & 15 & Mo \\
\hline & $3 . \ldots 8.0$ & 70 & 300 & 1.5 & $\mathrm{~N}$ & $\mathrm{~N}$ & $\mathbf{N}$ & 15 & 5 & $\mathbf{N}$ & 30 & \\
\hline & $4 \ldots .2 .4$ & $\mathrm{~N}$ & 200 & $\mathrm{~N}$ & $\mathbf{N}$ & $\mathrm{N}$ & $\mathrm{N}$ & 20 & 10 & $\mathrm{~N}$ & 30 & \\
\hline & $\begin{array}{ll}5 . \ldots & 1.3\end{array}$ & 30 & 200 & 2 & $\mathrm{~N}$ & $\mathrm{~N}$ & $\mathrm{~N}$ & 20 & 10 & $\mathrm{~N}$ & 20 & \\
\hline & M... 2.9 & 22 & 230 & 1 & $\ldots$ & $\ldots$ & 1.4 & 17 & 7.8 & $\ldots$ & 22 & \\
\hline & d. . . & 29 & 67 & .9 & . & $\ldots$ & 3.1 & 3 & 2.2 & $\cdots$ & 7.6 & \\
\hline
\end{tabular}


Table 1.-Direct-arc six-step spectrographic analyses of placer nugget gold from Lost Basin, Mohave County, Ariz.-Continued

[Values for silver are in percent and are quantitative; other elements are in parts per million and are semiquantitative. Number in parentheses indicates sensitivity of method for 5-mg sample. Symbols: L, element was detected but in an amount below the sensitivity limits; $N$, element was looked for but not found. Also looked for but not found: $A s(50), \operatorname{Te}(50), \operatorname{Mn}(5), \operatorname{La}(20), \operatorname{Ta}(500), \mathrm{Be}(1), \operatorname{Sb}(10)$, $\operatorname{Pt}(10), \operatorname{Pd}(5), \mathrm{Zn}(50), \mathrm{V}(5), \mathrm{Zr}(10), \mathrm{Ni}(10), \mathrm{Cd}(10), \mathrm{B}(2), \mathrm{Y}(2), \mathrm{Mo}(10), \mathrm{Sn}(5), \mathrm{Co}(5), \mathrm{W}(50), \mathrm{Nb}(10), \operatorname{Sc}(2), \mathrm{Cr}(5), \mathrm{Ba}(10), \operatorname{Sr}(50)$, $\mathrm{In}(5), \mathrm{Ga}(5), \mathrm{Ge}(5)$. "Other elements" column, occasionally detected elements-not frequent enough for statistical study]

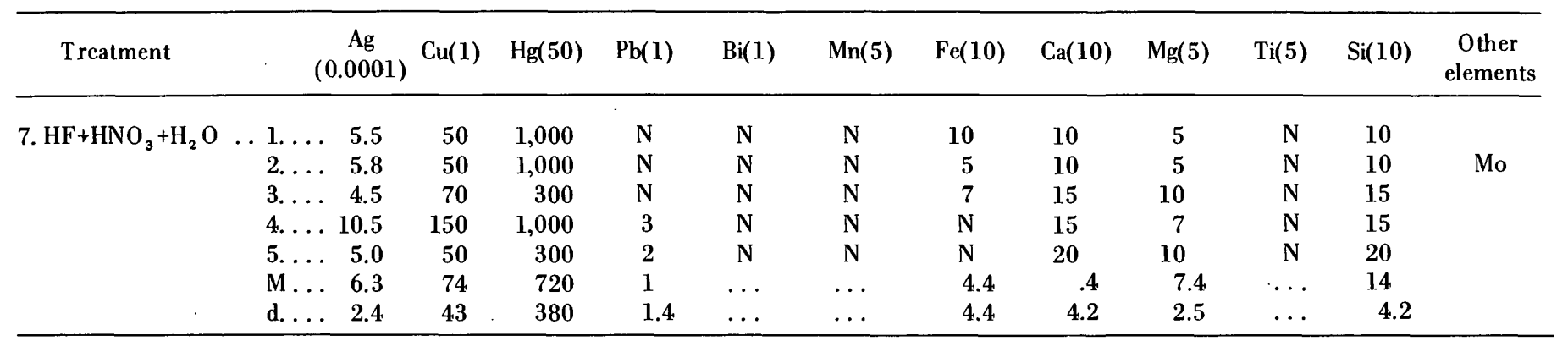

Table 2.-Direct-arc six-step spectrographic analyses of lode gold from Seafoam mine, Custer County, Idaho

[Values for silver are in percent and are quantitative; other elements are in parts per million and are semiquantitative. Number in parentheses indicates sensitivity of method for $5-\mathrm{mg}$ sample. Symbols: L, element was detected but in an amount below the sensitivity limit; N, element was looked for but not found; NA, not analyzed. Also looked for but not found: $\mathrm{As}(50), \mathrm{Te}(50), \mathrm{Mn}(5), \mathrm{La}(20)$, $\mathrm{Ta}(500), \operatorname{Be}(1), \operatorname{Pt}(10), \operatorname{Pd}(5), \mathrm{Zn}(50), \mathrm{V}(5), \mathrm{Zr}(10), \mathrm{Ni}(10), \mathrm{Cd}(10), \mathrm{B}(2), \mathrm{Y}(2), \operatorname{Mo}(10), \operatorname{Sn}(5), \operatorname{Co}(5), \mathrm{N}(50), \mathrm{Nb}(10), \operatorname{Sc}(2), \mathrm{Cr}(5)$, $\mathrm{Ba}(10), \mathrm{Sr}(50), \mathrm{In}(5), \mathrm{Ga}(5)$, and $\mathrm{Ge}(5)$. "Other elements" column, occasionally detected elements-not frequent enough for statistical study]

\begin{tabular}{|c|c|c|c|c|c|c|c|c|c|c|c|c|}
\hline Treatment & $\begin{array}{c}\mathrm{Ag} \\
(0.0001)\end{array}$ & $\mathrm{Cu}(1)$ & $\mathrm{Hg}(50)$ & $\mathrm{Pb}(1)$ & $\mathrm{Bi}(1)$ & $\mathrm{Sb}(1)$ & $\mathrm{Fe}(10)$ & $\mathrm{Ca}(10)$ & $\mathrm{Mg}(5)$ & $\operatorname{Ti}(5)$ & $\operatorname{Si}(10)$ & $\begin{array}{l}\text { Other } \\
\text { elements }\end{array}$ \\
\hline \multirow[t]{5}{*}{ 1. Untreated } & $1 . \ldots 12.5$ & 50 & 50 & 175 & 12.5 & 25 & 250 & $\mathrm{~N}$ & 25 & 40 & 700 & Mo \\
\hline & $2 \ldots 25.0$ & 70 & 50 & 125 & 12.5 & 25 & 325 & $\mathbf{N}$ & 20 & 12.5 & 700 & Mo \\
\hline & $3 . \ldots 12.5$ & 25 & 50 & 50 & 5 & 25 & 325 & 50 & 12 & 12.5 & 500 & \\
\hline & 4. . . 25.0 & 50 & 50 & 125 & 12.5 & 25 & 500 & 25 & 25 & 50 & 500 & \\
\hline & $5 . \ldots 25.0$ & 50 & 70 & 250 & 15 & 25 & 125 & 25 & 25 & 25 & 700 & $\mathrm{Y}$ \\
\hline Mean (M) & $\ldots \ldots 20.0$ & 49 & 54 & 145 & 11.5 & 25 & 305 & 20 & 21 & 28 & 620 & \\
\hline \multicolumn{13}{|c|}{ Standard devia- } \\
\hline tion $(\mathrm{d}) \ldots$ & . 7 & 16 & 9 & 74 & 3.8 & 0 & 136 & 21 & 6 & 17 & 110 & \\
\hline \multirow[t]{7}{*}{ 2. $\mathrm{HG}+\mathrm{H}_{2} \mathrm{O}$} & 1. . . 20.0 & 40 & 30 & 10 & 3 & 20 & 4 & $\mathbf{N}$ & $\mathrm{L}$ & $\mathrm{N}$ & 40 & \\
\hline & 2. . 20.0 & 40 & $\mathbf{N}$ & 4 & 3 & 20 & 2 & $\mathbf{N}$ & $\mathbf{L}$ & $\mathrm{N}$ & 30 & \\
\hline & $3 . \ldots 20.0$ & 40 & $\mathrm{~N}$ & 6 & 4 & 20 & 10 & $\mathrm{~N}$ & $\mathrm{~L}$ & $\mathbf{N}$ & 30 & \\
\hline & $4 \ldots 14.0$ & 40 & $\mathrm{~N}$ & 6 & 3 & 20 & 4 & $\mathbf{N}$ & $\mathrm{L}$ & $\mathbf{N}$ & 150 & \\
\hline & $5 . \ldots 28.0$ & 70 & 20 & 14 & 3 & 20 & 7 & $\mathrm{~N}$ & 15 & 7 & 70 & \\
\hline & M ... 20.4 & 46 & 10 & 8 & 3.2 & 20 & 5 & $\ldots$ & $\mathrm{L}(7)$ & 1.4 & 64 & \\
\hline & d. . . 5 & 13 & 14 & 4 & .5 & 0 & 3 & $\ldots$ & 4.5 & 3.1 & 50 & \\
\hline \multirow[t]{7}{*}{ 3. $\mathrm{HCl}+\mathrm{H}_{2} \mathrm{O}$} & $1 \ldots .5 .0$ & 5 & $\mathrm{~N}$ & 10 & $\mathbf{N}$ & $\mathrm{N}$ & 5 & 25 & 25 & $N$ & 250 & Mn \\
\hline & $2 \ldots \quad 5.0$ & 10 & $\mathrm{~N}$ & 10 & $\mathbf{N}$ & $\mathrm{N}$ & 10 & 50 & 25 & $\mathrm{~N}$ & 150 & \\
\hline & $3 . \ldots 7.0$ & 5 & $\mathrm{~N}$ & 15 & $\mathbf{N}$ & $\mathrm{N}$ & L & $\mathrm{N}$ & 35 & $\mathrm{~N}$ & 350 & \\
\hline & 4. . . 15.0 & 7 & $\mathbf{N}$ & 20 & $\mathrm{~N}$ & $\mathrm{~N}$ & 10 & $\mathbf{N}$ & $\mathrm{L}$ & $\mathrm{N}$ & 350 & . \\
\hline & $5 . \ldots 17.0$ & 9 & $\mathrm{~N}$ & 25 & $\mathbf{N}$ & $N$ & 50 & 50 & 17 & 17 & 500 & $\mathrm{Y}$ \\
\hline & M . . 9.9 & 7 & $\mathrm{~N}$ & 16 & $\ldots$ & $\ldots$ & $\mathrm{L}(1.0)$ & 25 & $\mathrm{~L}(20)$ & 3.4 & 320 & \\
\hline & d. . . 5.7 & 2.3 & $\ldots$ & 6.5 & $\ldots$ & $\ldots$ & 19 & 25 & 11 & 7.6 & 130 & \\
\hline \multirow[t]{7}{*}{ 4. $\mathrm{H}_{2} \mathrm{SO}_{4}+\mathrm{H}_{2} \mathrm{O}$} & $1 . \ldots 17.0$ & 50 & 25 & 17 & 3 & 30 & 30 & 30 & 17 & 30 & 850 & \\
\hline & $2 \ldots 12.0$ & 25 & 25 & 8 & 2 & 17 & 30 & 50 & 8 & 7 & 500 & \\
\hline & $3 . \ldots 17.0$ & 30 & 25 & 25 & 3 & 17 & 17 & 7 & 8 & 17 & 500 & $\mathrm{Y}$ \\
\hline & $4 . \ldots 13.0$ & 25 & 20 & 3 & 2 & 15 & 20 & 7 & 10 & 13 & 600 & \\
\hline & $5 \ldots 20.0$ & 50 & 20 & 50 & 7 & 20 & 30 & 20 & 10 & 70 & 1,000 & $\mathrm{Pt}$ \\
\hline & M . 15.8 & 36 & 23 & 21 & 3.4 & 20 & 25 & 23 & 10.6 & 27 & 690 & \\
\hline & d. . . 33 & 13 & 2.7 & 18.5 & 2 & 6 & 6.4 & 18 & 3.7 & 2.5 & 224 & \\
\hline
\end{tabular}


Table 2.-Direct-arc six-step spectrographic analyses of lode gold from Seafoam mine, Custer County, Idaho-Continued

\begin{tabular}{|c|c|c|c|c|c|c|c|c|c|c|c|c|}
\hline Treatment & $\begin{array}{c}\mathrm{Ag} \\
(0.0001)\end{array}$ & $\mathrm{Cu}(1)$ & $\mathrm{Hg}(50)$ & $\mathrm{Pb}(1)$ & $\operatorname{Bi}(1)$ & $\mathrm{Sb}(1)$ & $\mathrm{Fe}(1.0)$ & $\mathrm{Ca}(10)$ & $\operatorname{Mg}(5)$ & $\mathrm{Ti}(5)$ & $\mathrm{Si}(10)$ & $\begin{array}{c}\text { Other } \\
\text { elements }\end{array}$ \\
\hline \multirow[t]{7}{*}{ 5. $\mathrm{HNO}_{3}+\mathrm{H}_{2} \mathrm{O}$} & $1 . \ldots 20.0$ & 40 & $N$ & 60 & 2 & 20 & 30 & 1.0 & 14 & 10 & 600 & $\mathrm{Mn}$ \\
\hline & $2 \ldots 14.0$ & 30 & $\mathrm{~N}$ & 6 & $\mathrm{~N}$ & 20 & 20 & 10 & 10 & 40 & 600 & \\
\hline & 3. . . 20.0 & 60 & $\mathrm{~N}$ & 10 & 4 & 30 & 60 & 10 & 20 & 15 & 1,000 & Mn \\
\hline & $4 . \ldots 14.0$ & 40 & $\mathrm{~N}$ & 6 & 2 & 20 & 10 & 10 & 10 & $\mathrm{~N}$ & 600 & \\
\hline & $5 . \ldots 15.0$ & 30 & $\mathrm{~N}$ & 8 & 2 & 25 & 30 & 20 & 15 & $\mathrm{~N}$ & 800 & Mn \\
\hline & M...16.6 & 40 & $\ldots$ & 18 & 2 & 23 & 30 & 12 & 14 & 13 & 720 & \\
\hline & d. . . 3.1. & 12 & & 24 & 1.5 & 4.5 & 19 & 4.5 & 4 & 16 & 180 & \\
\hline \multirow[t]{7}{*}{ 6. $\mathrm{HF}+\mathrm{HCl}+\mathrm{H}_{2} \mathrm{O}$} & 1. . . 12.5 & 25 & $\mathrm{~N}$ & 5 & $\mathbf{N}$ & $\mathrm{N}$ & $\mathrm{L}$ & $\mathrm{L}$ & 15 & $\mathrm{~N}$ & 1.75 & \\
\hline & 2. . . 17.5 & 25 & $\mathrm{~N}$ & 7 & $\mathrm{~N}$ & $\mathrm{~N}$ & 2.5 & $\mathrm{~L}$ & 10 & $\mathrm{~N}$ & L & Mo \\
\hline & 5.0 & 12.5 & $\mathrm{~N}$ & 5 & $\mathrm{~N}$ & $\mathrm{~N}$ & $\mathrm{~L}$ & $\mathrm{~L}$ & L & $\mathbf{N}$ & L & \\
\hline & 4. . . 25.0 & 50 & $\mathbf{N}$ & 12 & $\mathbf{N}$ & $\mathrm{N}$ & 5 & $\mathrm{~L}$ & 15 & $\mathbf{N}$ & 12 & Mo \\
\hline & $5 . \ldots 10.0$ & 20 & $\mathbf{N}$ & 4 & 2 & 25 & 10 & $\mathrm{~L}$ & 10 & 200. & L & Mo \\
\hline & M. . 14.0 & 27 & $\ldots$ & 7 & .4 & 5 & $\mathrm{~L}(4.3)$ & $\ldots$ & $\mathrm{L}(11)$ & 40 & $\mathrm{~L}(43)$ & \\
\hline & d. ... 7.6 & 14 & $\ldots$ & 3 & .9 & 11 & 3.4 & $\ldots$ & 4.2 & 89 & 74 & \\
\hline \multirow[t]{7}{*}{ 7. $\mathrm{HF}+\mathrm{HNO}_{3}+\mathrm{H}_{2} \mathrm{O} \ldots$} & $1 . \ldots 12.0$ & 30 & $\mathrm{~L}$ & 2 & 4 & $\mathrm{~N}$ & 5 & $\mathrm{~L}$ & 8 & $\mathrm{~N}$ & 17 & \\
\hline & $2 \ldots 8.5$ & 17 & $\mathrm{~L}$ & 2 & 1.5 & $\mathrm{~N}$ & 12 & $\mathrm{~L}$ & 8 & $\mathrm{~N}$ & 8 & \\
\hline & $3 . \ldots 10.0$ & 30 & $\mathrm{~L}$ & 2 & $\mathbf{N}$ & $\mathrm{N}$ & 4 & $\mathrm{~L}$ & 15 & $\mathbf{N}$ & 10 & \\
\hline & $4 \ldots 14.0$ & 40 & $\mathrm{~L}$ & 2 & $\mathbf{N}$ & $\mathrm{N}$ & 6 & $L$ & 10 & $\mathrm{~N}$ & 30 & \\
\hline & 6.0 & 20 & 25 & 3 & $\mathrm{~N}$ & 17 & 2 & $\mathrm{~L}$ & 7 & $\mathrm{~N}$ & 12 & Mo \\
\hline & M.. 10.1 & 27 & 5 & 2.2 & 1.1 & 3.4 & 5.8 & $\ldots$ & 9.6 & $\ldots$ & 15 & \\
\hline & 3.0 & 9 & 11.2 & .5 & 1.7 & 7.6 & 3.8 & $\ldots$ & 3.2 & . & 8.8 & \\
\hline \multirow[t]{7}{*}{ 8. $\mathrm{HF}+\mathrm{H}_{2} \mathrm{SO}_{4}+\mathrm{H}_{2} \mathrm{O}$} & $1 . \ldots 12.5$ & 40 & $\mathrm{~N}$ & 5 & 5 & 25 & 2 & $\mathrm{~L}$ & 10 & $\mathrm{~N}$ & 15 & \\
\hline & $2 \ldots 17.5$ & 50 & $\mathrm{~N}$ & 5 & 2 & 25 & 3 & $\mathrm{~L}$ & 10 & $\mathrm{~N}$ & 15 & \\
\hline & 3. . 17.5 & 50 & $\mathrm{~N}$ & 15 & 10 & 25 & 10 & L & 10 & $N$ & 50 & \\
\hline & $4 \ldots 25.0$ & 70 & $\mathbf{N}$ & 10 & 5 & $\mathrm{~N}$ & 10 & $\mathrm{~L}$ & 15 & $\mathrm{~N}$ & 25 & \\
\hline & $5 \ldots 20.0$ & 40 & $\mathrm{~N}$ & 5 & 5 & $\mathrm{~N}$ & 5 & L & 20 & 20 & 20 & Mo \\
\hline & M. . 18.5 & 50 & $\ldots$ & 8 & 5.4 & 15 & 6 & $\ldots$ & 13 & 4 & 25 & \\
\hline & d. ... 4.5 & 12 & .. & 4.5 & 2.9 & 14 & 3.8 & $\ldots$ & 4.5 & 9 & 15 & \\
\hline \multirow{4}{*}{ 9. $\mathrm{HCl}+\mathrm{H}_{2} \mathrm{SO}_{4}+\mathrm{H}_{2} \mathrm{O}$. } & 5.0 & 15 & $\mathrm{~N}$ & 5 & $\mathrm{~N}$ & $\mathrm{~N}$ & 5 & L & 25 & $\mathrm{~N}$ & $\mathrm{~L}$ & Mo \\
\hline & $2 \ldots 30.0$ & 50 & $\mathbf{N}$ & 30 & 3 & 30 & 70 & L & 20 & 15 & 1.00 & Mo \\
\hline & M. $\ldots 17.5$ & 32.5 & $\ldots$ & 17.5 & 1.5 & 15 & 37.5 & $\ldots$ & 22.5 & 7.5 & $\mathrm{~L}(62.3)$ & \\
\hline & d. . . 17.7 & 24.7 & . & 17.7 & 2.1 & 21 & 46 & $\ldots$ & 46 & 11 & 53 & \\
\hline \multirow[t]{7}{*}{ 10. $\mathrm{Hg}+\mathrm{HNO}$. } & 1. . . 10.0 & 20 & NA & 20 & 7 & 10 & 50 & 30 & 50 & $\mathrm{~N}$ & 500 & $\mathrm{Mn}, \mathrm{B}, \mathrm{Ba}$ \\
\hline & $2 \ldots 15.0$ & 30 & NA & 15 & 2 & 10 & 30 & 30 & 30 & 5 & 500 & $\mathrm{Mn}$ \\
\hline & $3 \ldots 11.0$ & 20 & NA & 8 & 1.5 & 10 & 15 & 20 & 15 & 10 & 200 & $\mathrm{Mn}, \mathrm{Mo}, \mathrm{Ni}$ \\
\hline & $4 \ldots 11.0$ & 30 & NA & 8 & 1 & 10 & 20 & 30 & 20 & 5 & 300 & $\mathrm{Mn}$ \\
\hline & $5 \ldots 19.0$ & 30 & NA & 15 & 2 & 10 & 190 & 60 & 190 & 100 & 600 & $\mathrm{Mn}$ \\
\hline & M $\ldots 13.2$ & 26 & $\ldots$ & 13 & 2.7 & 10 & 61 & 34 & 61 & 24 & 420 & \\
\hline & d. ... 3.8 & 5.5 & $\ldots$ & 5 & 2.4 & 0 & 73 & 15 & 73 & 43 & 1.64 & \\
\hline \multirow[t]{7}{*}{ 11. Muffle at $650^{\circ} \mathrm{C}$} & 1... 8.0 & 15 & $\mathrm{~N}$ & 80 & 5 & 15 & 115 & 15 & 115 & $\mathrm{~N}$ & 300 & $\mathrm{Mn}$ \\
\hline & $2 \ldots 8.0$ & 25 & $\mathrm{~N}$ & 80 & 5 & 15 & 80 & 8 & 80 & $\mathrm{~N}$ & 500 & $\mathrm{Mn}$ \\
\hline & $3 . \ldots 25.0$ & 50 & $\mathrm{~N}$ & 330 & 15 & 30 & 80 & 8 & 80 & $\mathrm{~N}$ & 1,000 & $\mathrm{Mn}, \mathrm{B}$ \\
\hline & $4 . \ldots 8.0$ & 25 & $\mathrm{~N}$ & 110 & 8 & 15 & 115 & 8 & 115 & $\mathrm{~N}$ & 500 & $\mathrm{Mn}$ \\
\hline & $5 \ldots 13.0$ & 40 & $\mathrm{~N}$ & 130 & 13 & 25 & 260 & 13 & 260 & 90 & 250 & $\mathrm{Mn}, \mathrm{B}, \mathrm{Y}$ \\
\hline & М. . 12.4 & 31 & $\ldots$ & 246 & 9.2 & 20 & 130 & 10.4 & 130 & 18 & 960 & \\
\hline & d. . . 7.3 & 14 & 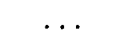 & 105 & 4.6 & 7 & 75 & 3.4 & 75 & 41 & 900 & \\
\hline
\end{tabular}

boron, and nickel than the Seafoam lode gold. On the other hand, the Seafoam gold contains antimony, barium, platinum, and yttrium-none of which were detected in the Lost Basin gold-and also contains appreciably more bismuth, calcium, titanium, lead, and silicon than the Lost Basin placer gold.

All the samples, whether treated or untreated, contain silver, copper and magnesium; silver and copper are alloy lattice constituents, but presumably may also occur in mineral impurities. Elements of high crustal abundance such as iron, calcium, magnesium, and silicon which occur in all or nearly all the samples analyzed probably represent either mineral impurities or grain boundary inclusions; for the nugget sample, at least, these elements cannot be regarded as surface coatings because most of the samples analyzed came from the interior of the nugget.

Mercury, an element of relatively low crustal abundance, is a major constituent of the Lost Basin placer nugget, but is scarcely identifiable in most of the. Seafoam lode samples. 
Reasons for this difference are not obvious, but one might speculate that the nugget accumulated mercury in its detrital environment or that much more mercury was present when mineralization occurred.

Lead was found in all the Seafoam splits, whether treated or not, and in most of the Lost Basin splits. Bismuth was detected more frequently in the Seafoam samples, but was also found in some Lost Basin samples. Antimony was found in some Seafoam samples, but in none of the Lost Basin samples. These chalcophilic elements probably occur as sulfide inclusions, and may be related to ore-forming processes, not only in the lode samples but in the nugget as well.

Iron was present in most of the splits. It is usually present in or on gold (Gay, 1963, p. 28) as sulfide or oxide inclusions rather than as an alloy constituent.

Platinum was detected in only one of the 97 splits. In general platinum occurs only rarely in gold (Antweiler and Sutton, 1970). Platinum in this sample may have been present either as a grain of the native metal or as an alloy constituent in a gold grain; in any event presence of platinum was confirmed by analyses of other samples from the Seafoam mine that were not a part of this test (Antweiler and Campbell, unpub. data).

Molybdenum was occasionally detected in the analysis of splits from both localities, but not consistently enough to justify conclusions about its behavior. The fact that it was detected in samples treated by several of the methods indicates that, if present, it may be able to withstand several of the procedures more effectively than the other elements do.

\section{STATISTICAL ANALYSIS}

Figures 1 and 2 show the mean value \pm one standard deviation of each element for each sample run with each treatment. Iron, lead, antimony, and bismuth show very significant variations caused by the leaching and also show a decrease in the amount of deviation around the mean. The value for lead in the roasted lode gold sample is virtually unaltered, but all other lead values decrease. The other elements (magnesium, silver, copper, mercury, and silicon) show an overall decrease in amounts present as compared to the untreated reference sample values. The elements least affected are silver (normally present in percentile values) and copper, but they still indicate an overall drop in content in the treated samples.

The results of a one-sided normal test (table 3) also show a difference for most elements and treatments in the average of the untreated reference samples compared to the average of the treated samples. If the difference in the means $\mathrm{M}^{\prime}$ is greater than the computed values of $\mu$, it is concluded that there is
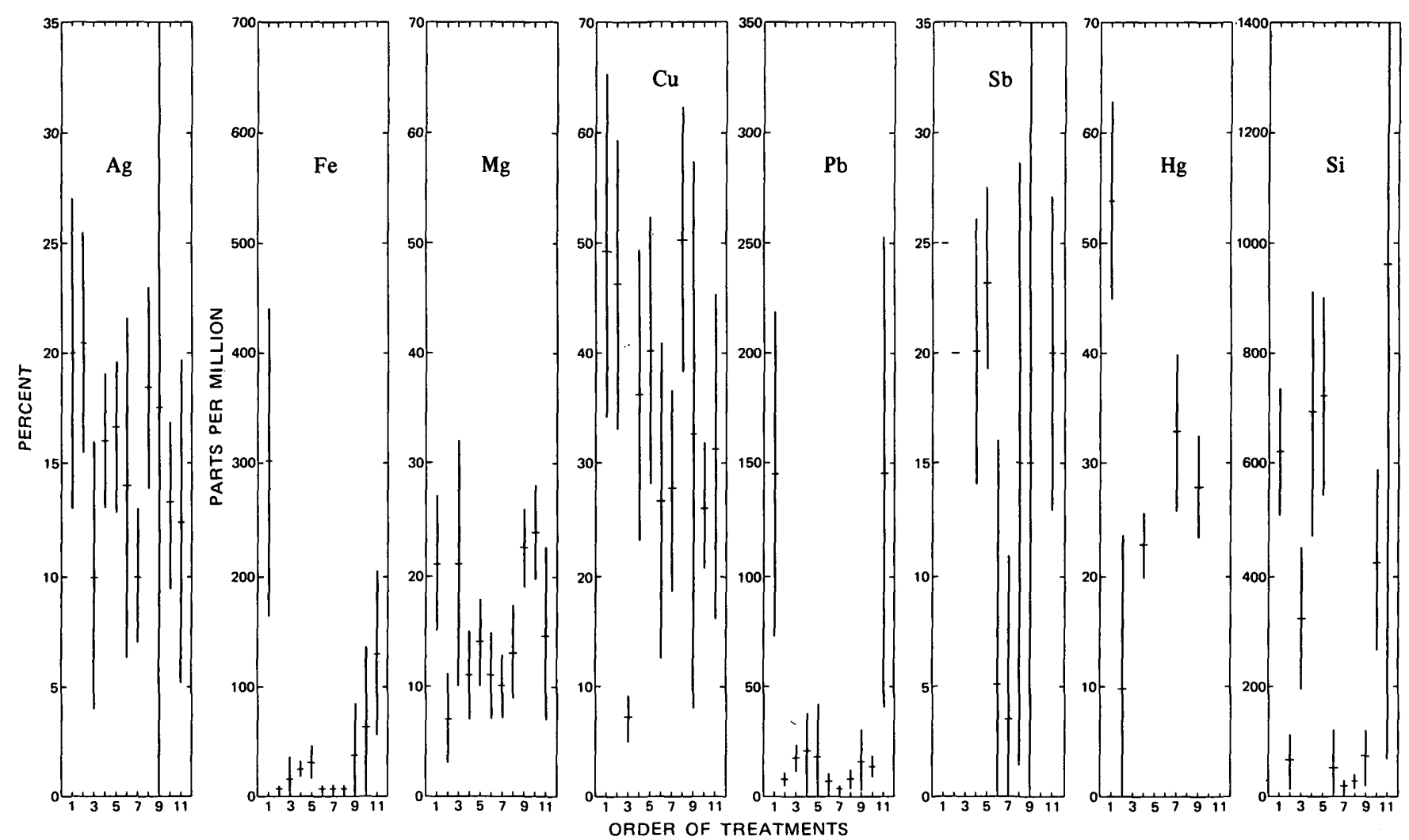

Figure 1.-Mean value \pm one standard deviation for elements in lode gold caused by various treatments. Numbers indicate order of treatments: (1) untreated, (2) $\mathrm{HF},(3) \mathrm{HCl}$, (4) $\mathrm{H}_{2} \mathrm{SO}_{4}$, (5) $\mathrm{HNO}_{3}$, (6) $\mathrm{HF}+\mathrm{HCl}$, (7) $\mathrm{HF}+\mathrm{HNO}_{3}$, (8) $\mathrm{HF}+\mathrm{H}_{2} \mathrm{SO}_{4}$, (9) $\mathrm{HCl}+\mathrm{H}_{2} \mathrm{SO}_{4},(10)$ amalgam, (11) muffle. Dash, mean value; vertical line, \pm one standard deviation. 

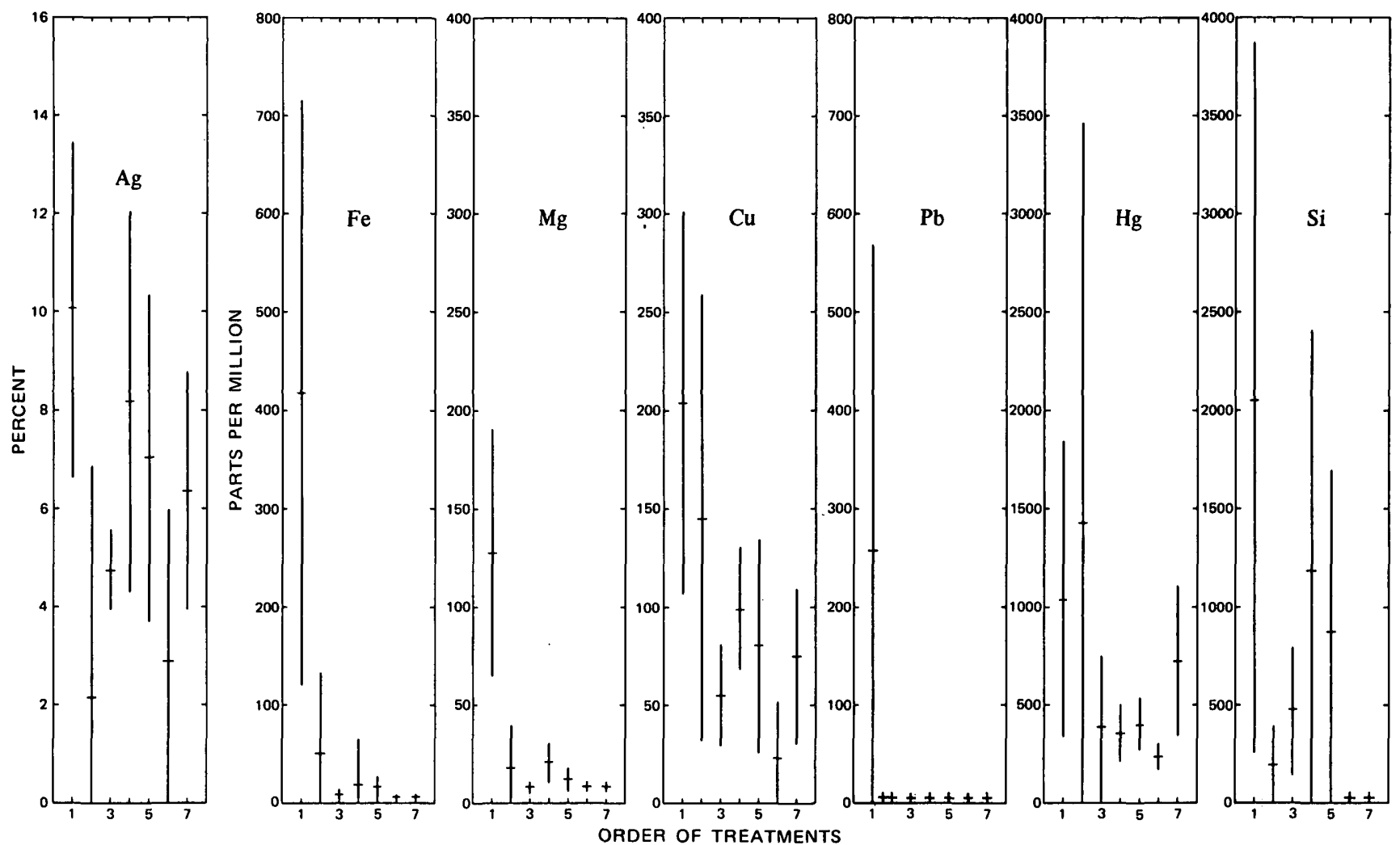

Figure 2.-Mean value \pm one standard deviation for elements in placer gold caused by various treatments. Numbers indicate order of treatments: (1) untreated, (2) $\mathrm{HF},(3) \mathrm{HCl},(4) \mathrm{H}_{2} \mathrm{SO}_{4}$, (5) $\mathrm{HNO}_{3}$, (6) $\mathrm{HF}+\mathrm{HCl},(7) \mathrm{HF}+\mathrm{HNO}_{3}$. Dash, mean value; vertical line, \pm one standard deviation.

reason to believe that the average of the reference sample exceeds that of the treated samples (Natrella, 1962, p. 3-20). Inasmuch as the treated samples and the reference sample were splits of one original sample, it must be surmised that the lower values in the treated samples are caused by the laboratory treatments.

To ascertain which of the treatments caused the smallest loss of elements from the gold, the determined amounts of all the elements, except silver, were combined and totaled. The total percentage loss was calculated by adding the totals of the element losses (in parts per million) for each fraction treated and dividing by the element totals (parts per million) in the untreated samples. These percentage losses are graphed on figure 3.

For the Seafoam gold, the most corrosive treatment was 1:1:1 $\mathrm{HF}: \mathrm{HNO}_{3}: \mathrm{H}_{2} \mathrm{O}$ solution, which leached 91 percent of the elements from the gold. The least corrosive was the roasting procedure, which caused a loss of 28 percent of the elements from the gold. These treatments, respectively, caused losses of 50 and 34 percent of the silver content.

The most corrosive leach on the Lost Basin gold was 1:1:1. $\mathrm{HF}: \mathrm{HCl}: \mathrm{H}_{2} \mathrm{O}$ solution (the treatment used by Crook (1939) to remove the gangue from the surface of gold prior to spectrographic analysis), which leached 86 percent of the elements from the gold. The least corrosive was $1: 1$

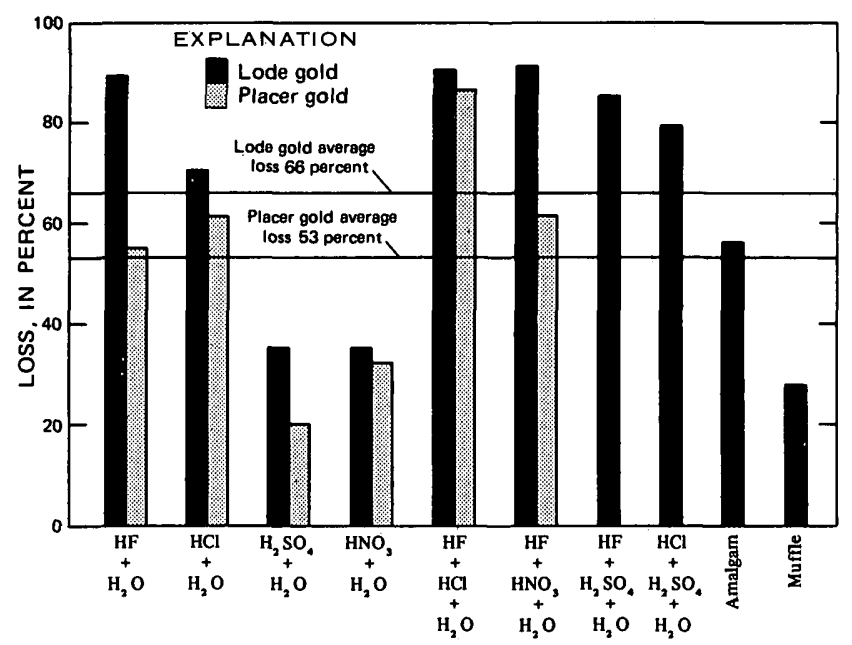

Figure 3.-Percentage losses of combined elements (except silver) based on total combined element content (except silver) of untreated gold samples.

$\mathrm{H}_{2} \mathrm{SO}_{4}: \mathrm{H}_{2} \mathrm{O}$ solution, which leached 21 percent of the elements from the gold.

Amalgamation of the Seafoam mine lode gold sample followed by $1: 1 \mathrm{HNO}_{3}: \mathrm{H}_{2} \mathrm{O}$ solution leaching to remove mercury caused a loss of 34 percent of the silver in the gold, 
Table 3.-One-sided normal test on placer nugget gold and on lode gold at 90 -percent confidence level

$\left[\mathrm{M}^{\prime}=\right.$ Mean of untreated reference sample minus mean of treated sample. $\mu=\mathrm{T}_{1-\alpha} \frac{\mathrm{S}}{\sqrt{n}}$, where $1-\alpha=0.9, \mathrm{~S}=$ standard deviation, and $\mathrm{n}=$ number of samples $\left(\mathrm{T}_{0.9}=\right.$ table values for cumulative normal distribution (Natrella, 1962, sec. 5, table A-4)). Italicized values show a significant difference]

\begin{tabular}{|c|c|c|c|c|c|c|c|c|c|c|c|c|}
\hline \multirow{2}{*}{ Treatment } & \multicolumn{2}{|c|}{$\mathrm{Ag}$} & \multicolumn{2}{|c|}{$\mathrm{Cu}$} & \multicolumn{2}{|c|}{$\mathrm{Hg}$} & \multicolumn{2}{|c|}{$\mathrm{Pb}$} & \multicolumn{2}{|c|}{$\mathrm{Bi}$} & \multicolumn{2}{|c|}{$\mathrm{Fe}$} \\
\hline & $\overline{\mathrm{M}^{\prime}}$ & $\bar{\mu}$ & $\overline{\mathrm{M}^{\prime}}$ & $\bar{\mu}$ & $\overline{\mathrm{M}^{\prime}}$ & $\bar{\mu}$ & $\overline{\mathbf{M}^{\prime}}$ & $\bar{\mu}$ & $\mathrm{M}^{\prime}$ & $\bar{\mu}$ & $\bar{M}^{\prime}$ & $\bar{\mu}$ \\
\hline \multicolumn{13}{|c|}{ Placer nugget gold } \\
\hline $\mathrm{HF}+\mathrm{H}_{2} \mathrm{O} \ldots$ & 8.0 & 3.3 & 47 & 79 & -350 & $1,4,00$ & 254 & 4 & $\ldots \ldots$ & $\ldots \ldots$ & 344 & 59 \\
\hline $\mathrm{HCl}+\mathrm{H}_{2} \mathrm{O} \ldots \ldots \ldots$ & 5.3 & .56 & 138 & 17.7 & 690 & 242 & 257 & 1 & $\ldots \ldots$ & $\ldots \ldots$ & 385 & 6 \\
\hline $\mathrm{H}_{2} \mathrm{SO}_{4}+\mathrm{H}_{2} \mathrm{O} \ldots \ldots \ldots$ & 1.9 & 2.6 & 94 & 22.4 & 740 & 104 & 258 & 1 & $\ldots \ldots$ & $\ldots \ldots$ & 374 & 13 \\
\hline $\mathrm{HNO}_{3}+\mathrm{H}_{2} \mathrm{O} \ldots \ldots \ldots$ & 3.0 & 2.2 & 111 & 37.3 & 680 & 93 & 258 & 1 & $\ldots \ldots$ & $\ldots \ldots$ & 377 & 93 \\
\hline $\mathrm{HF}+\mathrm{HCl}+\mathrm{H}_{2} \mathrm{O} \ldots \ldots$ & 7.2 & 2.1 & 169 & 20.5 & 850 & 47 & 258 & 1 & $\ldots \ldots$ & $\ldots \ldots$ & 392 & 2 \\
\hline $\mathrm{HF}+\mathrm{HNO}_{3}+\mathrm{H}_{2} \mathrm{O} \ldots \ldots$ & 3.8 & 1.7 & 118 & 29.8 & 360 & 260 & 258 & 1 & $\ldots \ldots$ & $\ldots \ldots$ & 389 & 3 \\
\hline \multicolumn{13}{|c|}{ Lode gold } \\
\hline $\mathrm{HF}+\mathrm{H}_{2} \mathrm{O}$. & -0.4 & 3.4 & 0.3 & 9.2 & 44 & 9.3 & 137 & 2.7 & 8.3 & 0.3 & 300 & 2.1 \\
\hline $\mathrm{HCl}+\mathrm{H}_{2} \mathrm{O}$ & 10.1 & 3.9 & 42 & 1.6 & 54 & 0 & 130 & 4.5 & 11.5 & 0 & 289 & 13 \\
\hline $\mathrm{H}_{2} \mathrm{SO}_{4}+\mathrm{H}_{2} \mathrm{O} \ldots \ldots \ldots$ & 4.2 & 2.2 & 13 & 8.9 & 31 & 1.9 & 124 & 12.7 & 8.1 & 2 & 280 & 4.4 \\
\hline $\mathrm{HNO}_{3}+\mathrm{H}_{2} \mathrm{O} \ldots \ldots \ldots$ & 3.4 & 2.1 & 9 & 8.4 & 54 & 0 & 127 & 16.1 & 10 & 1 & 275 & 13 \\
\hline $\mathrm{HF}+\mathrm{HCl}+\mathrm{H}_{2} \mathrm{O} \ldots \ldots \ldots$ & 6.0 & 5.2 & 23 & 9.3 & 54 & 0 & 138 & 2.2 & 11 & .7 & 301 & 2.3 \\
\hline $\mathrm{HF}+\mathrm{HNO}_{3}+\mathrm{H}_{2} \mathrm{O} \ldots \ldots$ & 9.9 & 2.1 & 22 & 6.2 & 21 & 4.6 & 143 & .3 & 10 & .9 & 299 & 2.6 \\
\hline $\mathrm{HF}+\mathrm{H}_{2} \mathrm{SO}_{4}+\mathrm{H}_{2} \mathrm{O} \ldots$ & 1.5 & 3.1 & -1 & 8.4 & 4 & 0 & 137 & 3.1 & 6 & 2 & 299 & 2.6 \\
\hline $\mathrm{HCl}+\mathrm{H}_{2} \mathrm{SO}_{4}+\mathrm{H}_{2} \mathrm{O} \ldots$ & 2.5 & 12.1 & 17 & 16.8 & 54 & 0 & 128 & 12.1 & 10 & 2 & 267 & 31.7 \\
\hline $\mathrm{Hg}$ amalgam. . . . . . . & 6.8 & 2.6 & 23 & 3.7 & $\ldots$ & . & 132 & 3.5 & 9 & 2 & 244 & 50.3 \\
\hline \multirow[t]{3}{*}{ Muffle at $650^{\circ} \mathrm{C} \ldots \ldots$} & 7.6 & 5.0 & 18 & 9.3 & 26 & 3.0 & -1 & 21.8 & 2.3 & 3.2 & 175 & 51.3 \\
\hline & \multicolumn{2}{|c|}{$\mathrm{Ca}$} & \multicolumn{2}{|c|}{$\mathrm{Mg}$} & \multicolumn{2}{|c|}{$\mathrm{Ti}$} & \multicolumn{2}{|c|}{$\mathrm{Si}$} & \multicolumn{2}{|c|}{$\mathrm{Al}$} & \multicolumn{2}{|c|}{$\mathrm{Sb}$} \\
\hline & $\overline{\mathrm{M}^{\prime}}$ & $\bar{\mu}$ & $\overline{\mathrm{M}^{\prime}}$ & $\bar{\mu}$ & $\overline{\mathbf{M}^{\prime}}$ & $\vec{\mu}$ & $\overline{M^{\prime}}$ & $\mu$ & $\overline{M^{\prime}}$ & $\bar{\mu}$ & $\overline{\mathrm{M}^{\prime}}$ & $\mu$ \\
\hline & \multicolumn{12}{|c|}{ Placer nugget gold } \\
\hline $\mathrm{HF}+\mathrm{H}_{2} \mathrm{O} \ldots$ & 10 & 26 & 109 & 13 & 34 & 15 & $1,900^{\circ}$ & 149 & 26 & 13 & . & \\
\hline $\mathrm{HCl}+\mathrm{H}_{2} \mathrm{O}$. & 33 & 3 & 120 & 1 & 44 & 0 & 1,600 & 224 & 36 & 2 & & \\
\hline $\mathrm{H}_{2} \mathrm{SO}_{4}+\mathrm{H}_{2} \mathrm{O} \ldots$ & 37 & 2 & 106 & 8 & 23 & 30 & 810 & 773 & 29 & 13 & $\cdots$ & \\
\hline $\mathrm{HNO}_{3}+\mathrm{H}_{2} \mathrm{O} \ldots \ldots \ldots$ & 34 & 6 & 115 & 4 & 24 & 30 & 1,200 & $578^{\circ}$ & 32 & 8 & & $\ldots$ \\
\hline $\mathrm{HF}+\mathrm{HCl}+\mathrm{H}_{2} \mathrm{O} \ldots$ & 32 & 2 & 119 & 2 & 44 & 0 & 2,000 & 6 & 38 & 3 & . & .. \\
\hline $\mathrm{HF}+\mathrm{HNO}_{3}+\mathrm{H}_{2} \mathrm{O} \ldots \ldots$ & 35 & 3 & 120 & 2 & 44 & 0 & 2,000 & 3 & 39 & 3 & & \\
\hline \multicolumn{13}{|c|}{ Lode gold } \\
\hline $\mathrm{HF}+\mathrm{H}_{2} \mathrm{O} \ldots \ldots \ldots$ & 20 & 0 & 14.4 & 3.1 & 27 & 11.2 & 560 & 37 & 104 & 0 & 5 & 0 \\
\hline $\mathrm{HCl}+\mathrm{H}_{2} \mathrm{O}$. & -5 & 17 & 0 & 7.6 & 27 & 1.9 & 300 & 93 & 86 & 8 & 25 & 0 \\
\hline $\mathrm{H}_{2} \mathrm{SO}_{4}+\mathrm{H}_{2} \mathrm{O} \ldots \ldots \ldots$ & -2 & 12 & 9.8 & 2.5 & 25 & 5.6 & -70 & 158 & 70 & 10 & 5.2 & 4 \\
\hline $\mathrm{HNO}_{3}+\mathrm{H}_{2} \mathrm{O} \ldots \ldots$ & 8 & 3 & 7.6 & 2.9 & 1 & 16 & -100 & 121 & 72 & 11 & 2 & 3 \\
\hline $\mathrm{HF}+\mathrm{HCl}+\mathrm{H}_{2} \mathrm{O} \ldots \ldots$ & -4 & 2 & 10.4 & 2.9 & 15 & 11.2 & 580 & 503 & 94 & 0 & 20 & 8 \\
\hline $\mathrm{HF}+\mathrm{HNO}_{3}+\mathrm{H}_{2} \mathrm{O}_{\ldots} \ldots$ & 2.8 & 2 & 11.8 & 2.2 & -12 & 61. & 605 & 6.5 & 97 & 2 & 22 & 5 \\
\hline $\mathrm{HF}+\mathrm{H}_{2} \mathrm{SO}_{4}+\mathrm{H}_{2} \mathrm{O} \ldots$ & -8 & 4.7 & 8.4 & 3.1 & 24 & 6.5 & 600 & 10 & 104 & 0 & 10 & 9 \\
\hline $\mathrm{HCl}+\mathrm{H}_{2} \mathrm{SO}_{4}+\mathrm{H}_{2} 0 \ldots$ & -20 & 9.3 & -1.1 & 2.4 & 20 & 7.5 & 560 & 37 & 97 & 8 & 10 & 15 \\
\hline $\mathrm{Hg}$ amalgam $\ldots \ldots \ldots$ & -14 & 10 & -2.6 & 2.9 & 4 & 29 & 200 & 112 & 68 & 12 & 15 & 0 \\
\hline Muffle at $650^{\circ} \mathrm{C} \ldots \ldots$ & 9.6 & 2.3 & 7.0 & 5.3 & 10 & 27 & -340 & 7 & 67 & 11 & 5 & 5 \\
\hline
\end{tabular}

but $1: 1 \mathrm{HNO}_{3}: \mathrm{H}_{2} \mathrm{O}$ leach without prior amalgamation caused only a 17 -percent loss. The difference in the two values can probably be attributed to differential removal of silver caused by solution of gold with mercury.

The percentage loss of total minor trace elements for Seafoam lode gold was higher than the loss for the Lost Basin nugget sample. The 13-percent difference (fig. 3) could be a function of the particle size because the vein gold was approximately 200 mesh in size, whereas the nugget gold samples were about 40 mesh. But it may also reflect, in part, natural refining in the detrital environment.

\section{RESULTS OF MICROPROBE ANALYSIS}

Seafoam lode gold treated with mercury and nitric acid develops rims which are comparable to the leached rims on placer gold samples reported by Desborough (1970, p. 310). 
These rims are visible on carbon-coated gold prepared for the electron-beam microprobe analyses, are very distinct under high magnification, and are verified by analysis.

The effects of amalgamation, 1:1:1. HF: $\mathrm{HCl}: \mathrm{H}_{2} \mathrm{O}$ leaching, and roasting in the muffle furnace on the profile cross section as determined by spot analysis with the electron-beam microprobe across the individual grains (fig. 4) show that the surface rims are greatly reduced in silver content with most all the silver being removed from the outer $4 \mu$ of the grains. The profile of untreated samples, on the other hand, shows some variation in silver content, but no indication of silver-deficient edges.
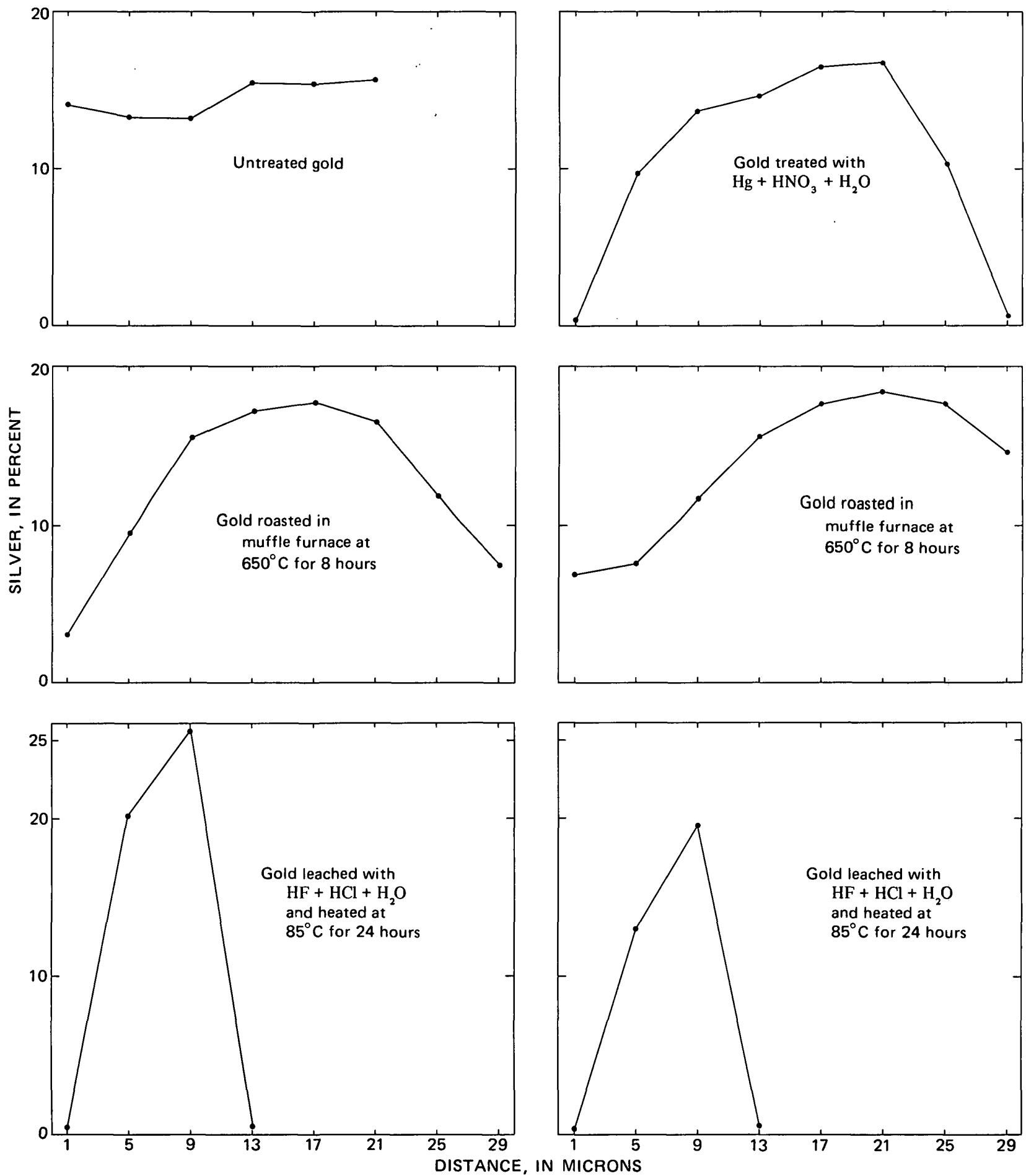

Figurc 4.-The effects of laboratory treatment on silver profiles of lode gold as determined by electron-beam microprobe step scan of single grains. 


\section{CONCLUSIONS}

Trace-element assemblages and concentrations in native gold are the means by which the characteristic signature of gold deposits can be determined. Although some samples must be roasted, amalgamated, or leached to recover gold, the data of the study show that these recovery procedures cause losses of most elements associated with or contained in the gold. Thus, unless specific knowledge of the effects produced by recovery procedures on a particular sample of gold are understood, interpretation of compositional data may not be valid.

\section{REFERENCES CITED}

Antweiler, J. C., and Sutton, A. L., Jr., 1970, Spectrochemical analyses of native gold samples: U.S. Geol. Survey Rept. USGS-GD-70-003, 28 p.; available only from U.S. Dept. Commerce Natl. Tech. Inf.
Service, Springfield, Va. 22151, as Rept. PB1-94809.

Crook, W. S., 1939, Preliminary spectrographic and metallographic study of native gold: Am. Inst. Mining Metall. Engineers, Tech. Pub. 998.

Desborough, G. A., 1970, Silver depletion indicated by microanalysis of gold from placer occurrences, Western United States: Econ. Geology, v. 65, p. 304-311.

Gay, N. C., 1963, A review of the geochemical characteristics of gold in ore deposits: Witwatersrand Univ. Econ. Geology Research Unit Inf. Circ. $12,70 \mathrm{p}$.

Natrella, M. G., 1962, Comparing materials or products with respect to average performance, chap. 3, p. 3-1 to 3-42, in Experimental statistics-Sec. 1, Basic statistical concepts and standard techniques for analysis and interpretation of measurement data: U.S. Natl. Bur. Standards Ordnance Eng. Design Handb., Ordnance Corps Pamph. ORDP 20-110, 178 p.; also Sec. 5, Tables, Ordnance Corps Pamph. ORDP 20-114, 89 p. [Reprinted 1963]

Ross, C. P., 1930, Geology and ore deposits of the Seafoam, Alder Creek, Little Smoky, and Willow Creek mining districts, Custer and Camas Counties, Idaho: Idaho Bur. Mines and Geology Pamph. 33, $26 \mathrm{p}$. 


\title{
A PRECAUTIONARY NOTE ON THE USE OF MIXED SOLVENTS IN SOXHLET EXTRACTION PROCEDURES
}

\author{
By ALAN A. ROBERTS and JAMES G. PALACAS, Denver, Colo.
}

\begin{abstract}
The variation in solvent composition of a mixed solvent used in Soxhlet extraction of sediments has apparently often been overlooked. Owing to azeotropic distillation of the solvent introduced into the apparatus, care must be taken to determine the composition of the solvent actually doing the extracting.
\end{abstract}

During our studies on hydrocarbons in recent sediments, several methods were tested to extract organic matter from samples. One of these methods, extraction of sediment samples in a Soxhlet apparatus using a variety of mixed solvents, has been used by many research workers. One of the most common solvent mixtures used in such Soxhlet extractions is a benzene-methanol mixture with ratios of benzene to methanol ranging from 9:1 to $1: 2$. In a cursory examination of the geochemical literature of the past 5 years we have noted in at least 15 papers in some eight different periodicals what appears to be a common oversight involved in such extractions-that the sample is assumed to be extracted by mixed solvent of the same composition as that introduced into the Soxhlet apparatus.

A Soxhlet apparatus allows repeated extraction of the sample with freshly distilled solvent. Because of the formation of an azeotrope, the composition of the mixed solvent that is distilled in such an extraction apparatus, however, is generally somewhat different from that which was introduced into the flask. For example, boiling-point (phase) diagrams for benzene-methanol mixtures (fig. 1) indicate a constant vapor concentration of about 58 volume percent benzene for distillation of liquid mixtures between about 45 and 90 volume percent benzene (Williams and others, 1948; Timmermans, 1959, p. 51-52). Outside this range the vapor will be enriched in one or the other solvent.

We have experimentally determined that the distillation within a Soxhlet apparatus of benzene-methanol mixtures that contain between 50 and 90 volume percent benzene does indeed yield a distillate composed of $58.5 \pm 0.5$ volume percent benzene. Therefore, even if one were to use a starting solution of 90 volume percent benzene and 10 volume percent methanol, the distillate, which does the extracting, would initially be only about 60 percent benzene. As this distillate is

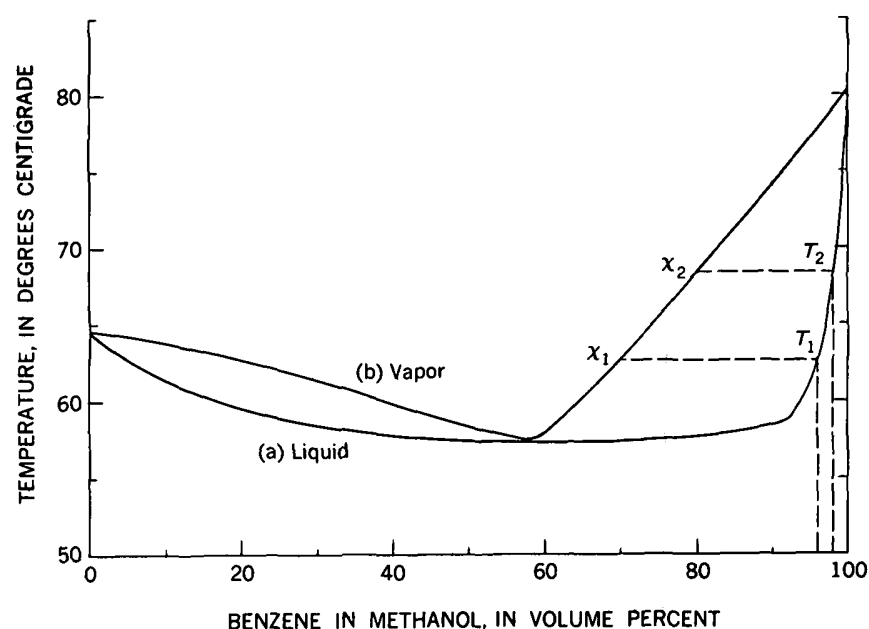

Figure 1.-Boiling point-composition diagram for benzene-methanol mixtures (data from Timmermans, 1959). The $63^{\circ}$ boiling-point value at $T_{1}$ of a 96 volume percent benzene in methanol mixture projected to $x_{1}$ indicates that the vapor-phase composition is 70 volume percent benzene. Inasmuch as the vapor has a higher concentration of methanol than the liquid, the liquid becomes enriched in benzene as the distillation proceeds. When the liquid reaches a composition of 98 volume percent benzene and 2 volume percent methanol, it boils at $68^{\circ} \mathrm{C}\left(T_{2}\right)$ and the vapor has an 80 volume percent composition $\left(x_{2}\right)$. With further distillation the liquid is enriched in benzene until only pure benzene results. The relative flatness of curve a between 45 and 90 volume percent benzene indicates that within this range of liquid composition the vapors are very close to the minimum-boiling azeotropic composition of 58 volume percent benzene.

removed, the liquid, and hence the vapor, will gradually become more enriched in benzene until all the methanol has distilled off or the solvent in the Soxhlet thimble has siphoned over, restarting the cycle. Thus, the extraction solvent would not be the $9: 1$ benzene-methanol mixture introduced into the apparatus.

One further noteworthy example in which the composition of the Soxhlet extract could be significantly altered by the effect of azeotrope formation is found in the toluenemethanol system. In this case the azeotropic mixture that would be distilled and do the extracting is mostly methanol (toluene: methanol $=2: 5$ by volume) in contrast to the usually 
desired and apparently expected ratio of toluene to methanol of 3 or 4 to 1. Other solvent systems forming azeotropes should behave in a similar manner.

We, therefore, emphasize that whenever mixed solvents are used in Soxhlet extraction the composition of the liquid mixture should be identical with that of the constant-boiling azeotropic mixture, where applicable, in order to ensure that the extraction is being done by solvent of known and constant composition. For the benzene-methanol system this composition is 58 volume percent benzene and 42 volume percent methanol.
Acknowledgments.-We wish to thank Dr. William S. Ferguson, Colorado State University, Fort Collins, Colo., for his helpful discussions and critical review of this note.

\section{REFERENCES CITED}

Timmermans, Jean, ed., 1959, The physico-chemical constants of binary systems in concentrated solutions: New York, Interscience Publishers, v. 2, 1284 p.

Williams, G. C., Rosenberg, S., and Rothenberg, H. A., 1948, Physical properties of benzene-methanol mixtures: Indus. Eng. Chemistry, v. 40 , p. $1273-1275$. 


\title{
PHOTOMECHANICAL EXPERIMENTS IN AUTOMATED CARTOGRAPHY
}

\author{
By C. R. GILMAN, McLean, Va.
}

\begin{abstract}
The U.S. Geological Survey recently undertook the investigation of two seemingly unrelated cartographic tasks: (1) the preparation of map copy for digitizing and (2) the production of experimental slope maps. Both tasks, however, require techniques and equipment for changing or manipulating the line weights of existing map symbols and producing suitable reproduction copy. After a study of existing equipment, a prototype revolving illuminator was designed and fabricated for experiments in line-weight manipulation. Sufficient exposures have been made with the device to indicate that positive control of line-weight increases and decreases up to 0.2 inch is attainable. The device has been used for photomechanical experiments in slope mapping, hill shading, and preparation of map copy for digitizing.
\end{abstract}

\section{PHOTOMECHANICAL MANIPULATION OF MAP SYMBOLS}

A major effort in U.S. Geological Survey research is devoted to developing automated techniques for increasing speed and efficiency in the cartographic phases of map revision. The goal is to produce a digitally generated map with input derived from color-separation materials of an existing map and graphic revision data.

Concurrently, a project was undertaken to develop techniques and associated equipment for slope-map production. A fast, reliable, economical way was needed to replace the tedious hand method of delineating slope zones. A computer-assisted type of compilation was first investigated, but this approach was abandoned because of the overwhelming tasks of digitizing all the contours and preparing programs to extract and plot the slope zones. The approach now under investigation is a photomechanical technique that widens contours by predetermined amounts so that contours touching each other indicate specific slope zones.

If the line weights could be controlled in reducing as well as in widening, it was reasoned, then the approach used in slope mapping experiments could also be used in separating other types of màp symbols into groups convenient for digitizing.

\section{Methods of line-weight manipulation}

Methods of line-weight manipulation can be divided into three general categories:
1. Spreading and compression. In this process, the recording film is separated from the line copy by a transparent spacer and overexposed so that the recorded lines are spread if exposed through negative copy or compressed if exposed through positive copy. The amount and predictability of line-weight change is limited with this method.

2. Orbiting of images. There are methods of moving images projected from the original copy in a circular motion over the surface of the recording film so that the dimensions of the original symbols can be increased or decreased by a controlled amount. This action produces the same effect as if the original copy were being moved. In these methods, negative copy is used to generate added dimension, and positive copy is used to reduce dimensions. The amount added or subtracted is equal to the diameter of the circular movement of the image.

3. Shaking. This term could be applied to methods of moving the original copy by controlled amounts in relation to the recording film, or conversely, moving the recording film in relation to the original copy. The task would be difficult to achieve because the film and original copy would have to remain in close contact during exposure. We are not aware of any devices for accomplishing this task.

\section{Revolving illuminator}

Of these methods, the ones that appear easiest to control are those of the orbiting type. Accordingly, a revolving illuminator was developed and tested by the U.S. Geological Survey as an aid to photomechanical map-symbol manipulation. It offers a means of changing line weights without affecting the shapes of map symbols, and with no appreciable change in map scale. As the term implies, it is the illuminating lamps which revolve and thereby generate the image motion on the recording film. Map copy in the form of a film positive or negative is contained in a vacuum frame and separated from the recording film by a transparent spacer. Light rays from the revolving lamps pass through the film copy at preset angles and through the spacer to expose the recording film. The angles at which the rays pass to the recording film can be controlled by the distance between the lamps and the distance between the illuminator and the vacuum frame (fig. 1). Exposures can be controlled by the illumination level and exposure time. 


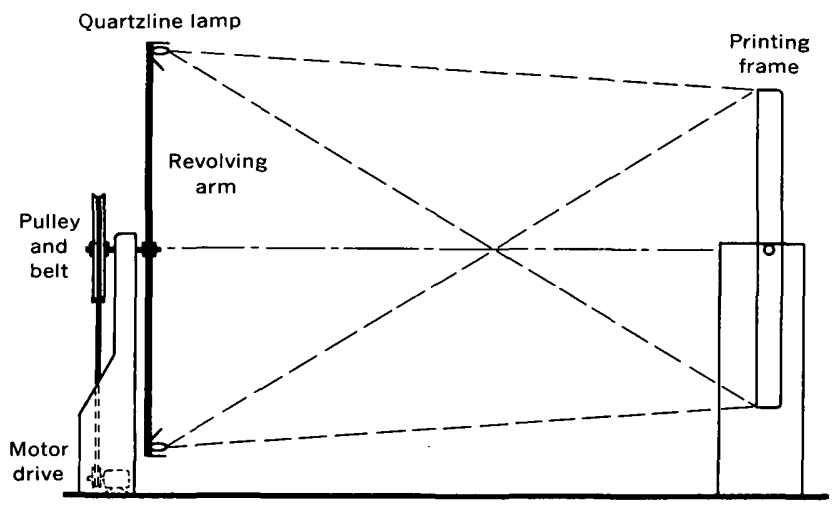

$A$
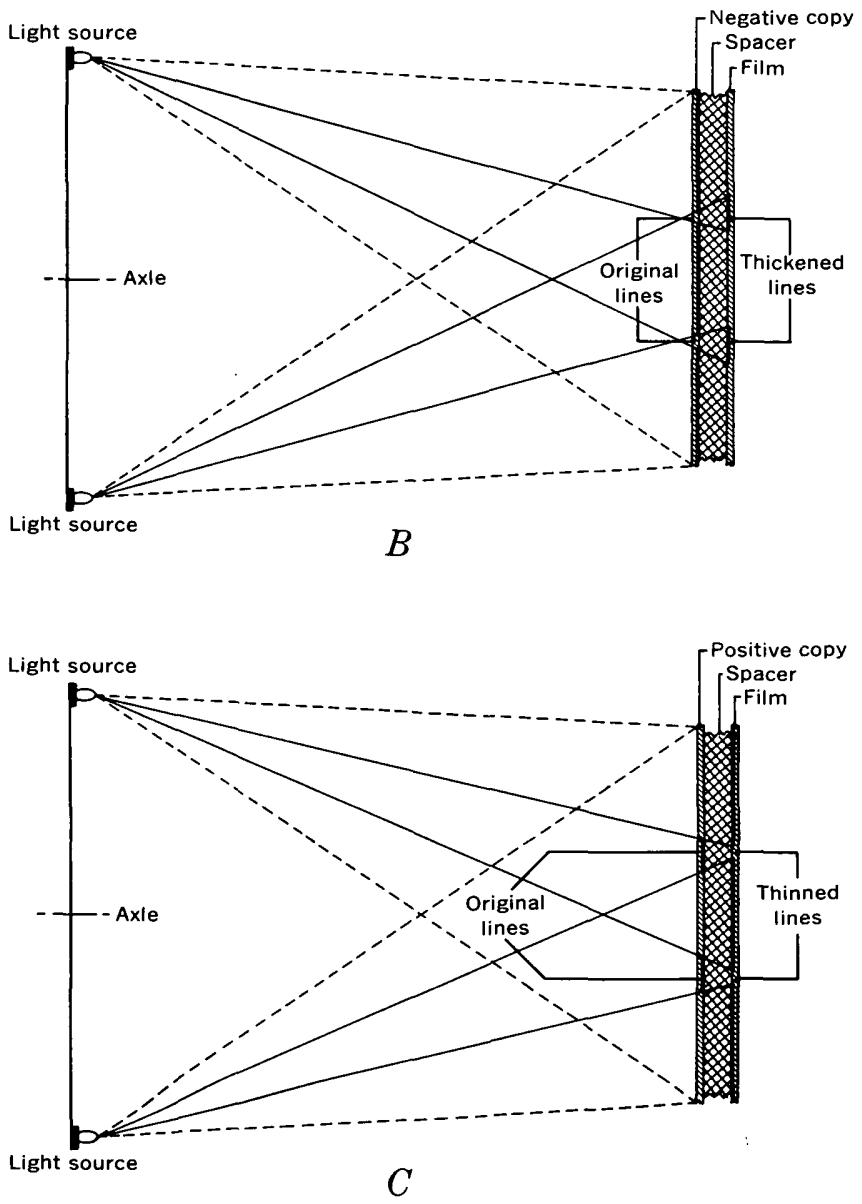

Figure 1.-Diagrams of the revolving illuminator. $A$. Relationship of revolving illuminator to printing frame. $B$. Arrangement for increasing line weight or symbol size. $C$. Arrangement for reducing line weight or symbol size.

The revolving illuminator consists principally of a stand, which houses the electrical-mechanical parts and supports the revolving arm; the controls for illumination and the driving motor; and the revolving arm, which holds the lamps. The lamps are of the quartz-halogen type, 19 volts, 80 watts. The control box contains independent on-off switches for illumination and the drive motor. An autotransformer is used for varying the illumination and the revolving speed. The lamps can be moved to any desired position along the arm, and the hoods on the lamps prevent stray light from causing spurious exposures.

In manipulating line weights, the period of exposure and the intensity of illumination are relatively important for obtaining the desired photographic product. If simple contact exposures were being made, relatively short exposures would be sufficient to equally expose lines of various weights. However, with image movement involved, each part of the negative copy acts as an individual aperture; and the wider lines, of course, provide larger apertures. Thus narrow lines must get more exposure than wider lines, either by more time or increased illumination. Tradeoffs can be made in exposure time and illumination intensity to provide both quality of product and efficiency in processing. Most experimental exposures were made at a distance of 6 feet, with the lights separated 60 inches. Transparent spacers used thus far have been 0.005-inch Mylar, 0.010- and 0.020-inch acetate, and $1 / 32-, 1 / 16-, 1 / 10-, 1 / 8-$, and $1 / 4$-inch Plexiglas. It is entirely practical to sandwich two or three spacers to arrive at a desired thickness. Line-weight increases and decreases ranging from 0.003 to 0.190 inch have been recorded repeatedly.

Advantages of the revolving illuminator are:

1. A copy camera is not needed.

2. Large or small adjustments can be made in distance between lamps, distance to vacuum frame, and intensity of illumination.

3. Orientation of the illuminator relative to the plane of the vacuum frame can be changed, depending on the task at hand.

4. Working models can be economically constructed in sizes tailored to fit laboratory spaces or the size of map copy.

5. Line-weight additions or reductions are consistent throughout the format.

6. The range of line-weight change is considerable.

The principal disadvantage appears to be the slight outward radial displacement of the recorded images. For some purposes this displacement might be of no concern; for others of exacting requirements, it might be excessive. Radial displacement can be minimized by maintaining a maximum separation between the illuminating lamps. When successive exposures are made, radial displacement is always cumulative, whether the line weights are increased or reduced. It therefore behooves the cartographer to plan the processing in as few steps as possible. If the end product exceeds the allowable limits of scale, it must be processed through a copy camera to recover the desired scale.

\section{PREPARATION OF MAP COPY FOR DIGITIZING}

The U.S. Geological Survey is developing automated tech- 
niques for producing a digitally generated map from colorseparation materials of an existing map, new aerial photographs, and ground information. The culture (black) plate contains the widest variety of map symbols (fig. $2 A$ ). To reduce manual editing of digitized information, culture symbols must be separated into categories before being scanned. Other color-separation drawings-contours, woodland, drainage-can be scanned with little or no modification. A functional automatic scanning system records symbols by groups in digital format. Such digital cartographic information would be a principal input to an automated system for map revision.

All culture symbols in current use for topographic mapping were classified by dimension and analyzed to determine the possibility of photomechanically separating them for scanning. It was found that many symbols fall in two categories, and a few fall in three categories. It therefore seems impossible to separate symbols completely on the basis of equal-dimension categories. The analysis did indicate, however, that many symbols, or parts of them, could be separated into groups having the dimensions, in inches, of 0.002 and 0.003 ; $0.005-0.008 ; 0.010$ and $0.012 ; 0.016$ and $0.017 ;$ and 0.020 and larger.

In experiments with black-plate symbols, a photomechanical method was developed for deleting or retaining selected groups of symbols by line-width discrimination. This method involves the revolving illuminator to selectively and predictably control the spreading and reducing of line widths on lithographic films. Combinations of these films and the original plate are used in intermediate masking steps to produce plates with different categories of symbols. The series of resultant abridged plates can serve as input for digitizing. Since the experiments began, the process has been refined so that now fewer intermediate steps are needed to arrive at the desired product. Figures $2 B$ and $2 C$ illustrate some of the categories of symbols that can be isolated.

\section{SLOPE MAPPING}

A slope map is a special-purpose map on which areas of similar slope are represented by a distinguishable pattern or color. Slope maps can be designed with a wide range in the number of slope categories. A simple map may include three slope categories, whereas a detailed large-scale map might contain 15 to 20 categories, usually with greater detail in the lower gradients. By looking at a good topographic map we can tell at a glance which areas are steep, flat, or in between; but without actually converting a topographic map to a slope map in some way, it is difficult to go beyond these simple slope categories with any degree of accuracy.

In a series of experiments in Menlo Park, Calif., and McLean, Va., modified 10-foot-interval contour negatives at 1:24,000 scale were used as source data for generating slope maps by photomechanical methods. To eliminate sources of spurious
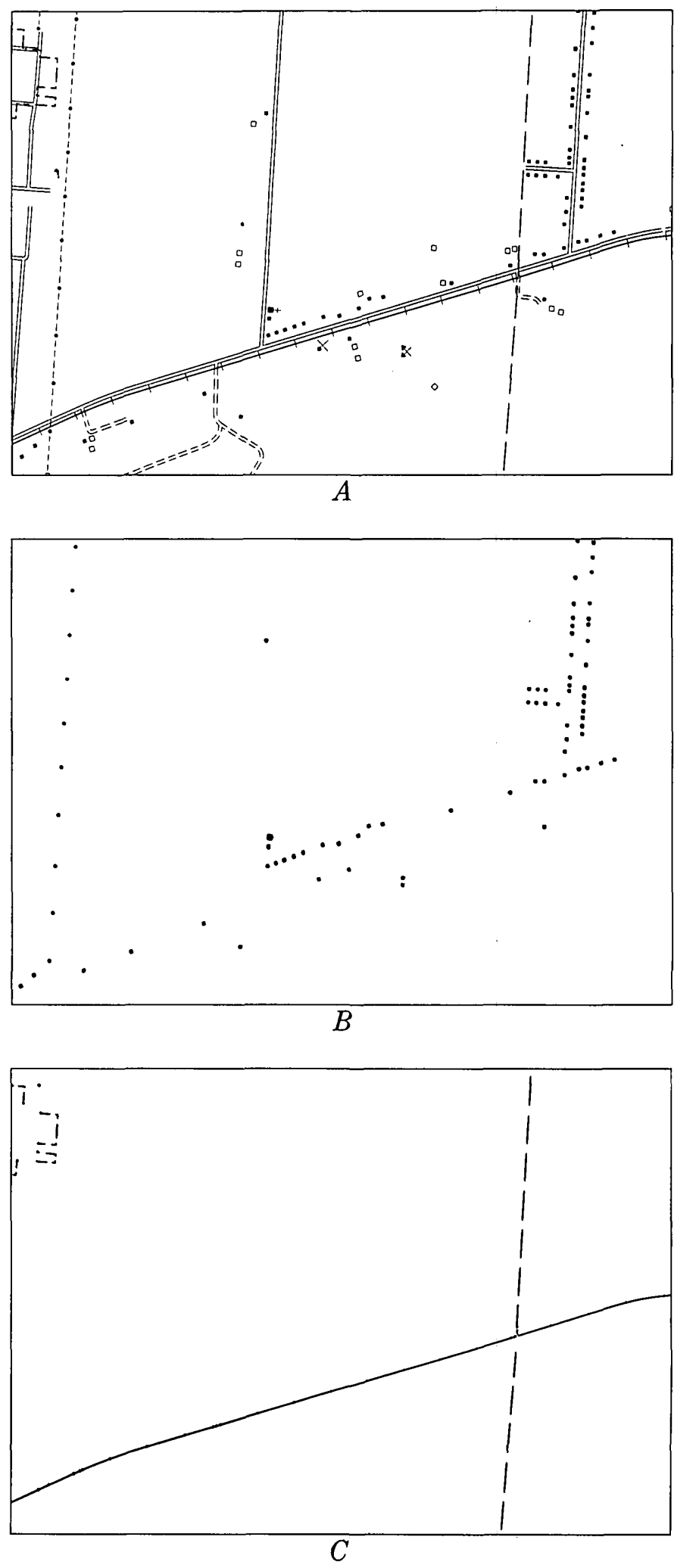

Figure 2.-Categories of map symbols with similar line weights that can be isolated from the original plate by photomechanical methods. $A$. Original culture (black) plate with variety of map symbols. $B$. Isolated symbols 0.02 -inch and larger line dimension. $C$. Isolated symbols 0.005 - to 0.008 -inch line dimension. 
slope zones, contour labels, spot elevations, and other disruptive symbols had to be removed from the contour copy. The revolving illuminator was used in a process to bring the index contours to the same line weight as the intermediate contours. Limited amounts of the normal cartographic techniques of opaquing, masking, etching, and scribing were also used to modify the contour copy. Figure $3 A$ illustrates a part of the modified contour plate used for generating slope zones.

In producing the color-separation copy for the various slope zones, the revolving illuminator was used, with the modified contour copy as original input, in a series of controlled manipulations of line weight and masking steps. The slope map illustrated in figure $3 B$ contains five slope zones which were photomechanically generated in a series of 15 steps. Each of the zones is separated so that it can be printed in any distinctive color. The map contains some spurious slope zones which have been generated by proximity of parts of the same contour line at drain reentrants and tops of hills or ridges.

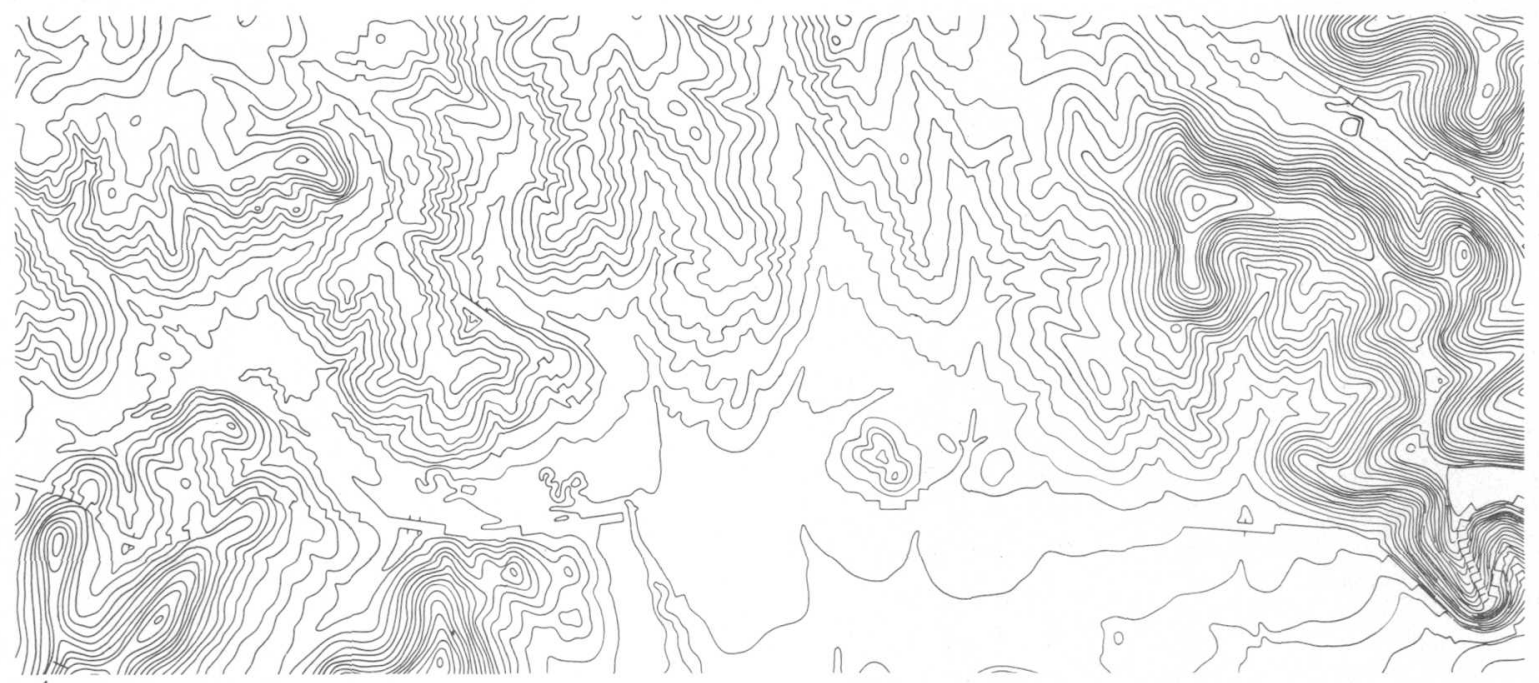

A

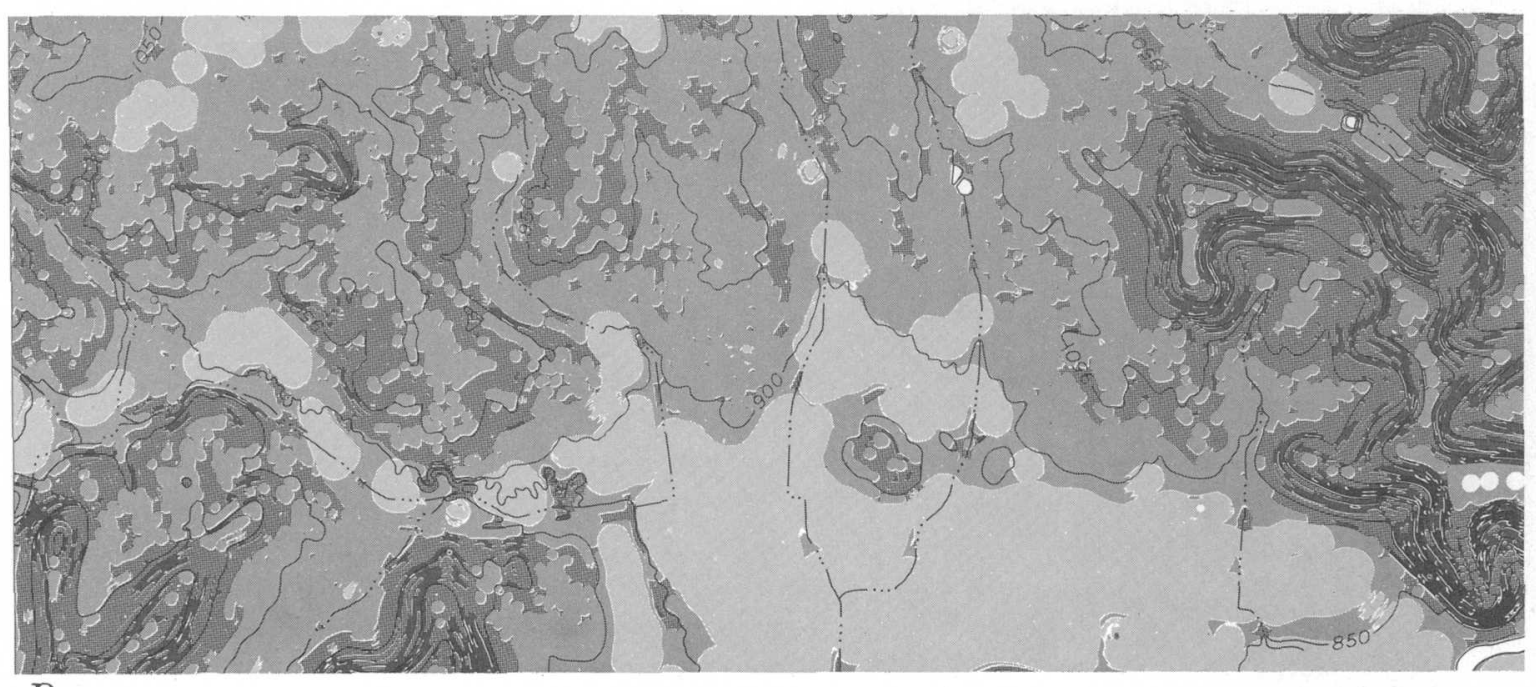

$B$

SLOPE, IN PERCENT

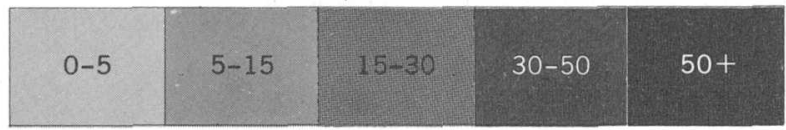

Figure 3.-Input and product of photomechanical slope mapping. A. Modified contour copy used for generating slope map. Width of index contours was reduced by photomechanical techniques, and contour numbers were removed manually. $B$. Part of a slope map produced by photomechanical methods. 


\section{SEMIAUTOMATIC RELIEF SHADING}

The Geological Survey publishes shaded-relief editions of selected topographic maps that show physiographic features of special interest. On these editions, the shading accentuates the physical features by simulating the appearance of sunlight and shadows on the terrain and conveys an illusion of a threedimensional land surface. Until now, the shading for these maps has been rendered by airbrush.

The photomechanical method of relief shading now being developed shows promise of replacing the tedious manual method. The cartographer chooses the direction of illumination and constructs a mask to separate illuminated slopes from shaded slopes. A negative image of the contour lines is then subjected to a line-enhancing process in which contours are thickened in the direction of illumination. In this process the revolving illuminator is turned edgewise to the copy and thus widens the contour lines in a direction controlled by the orientation of the copy. Then in a series of photographic steps,

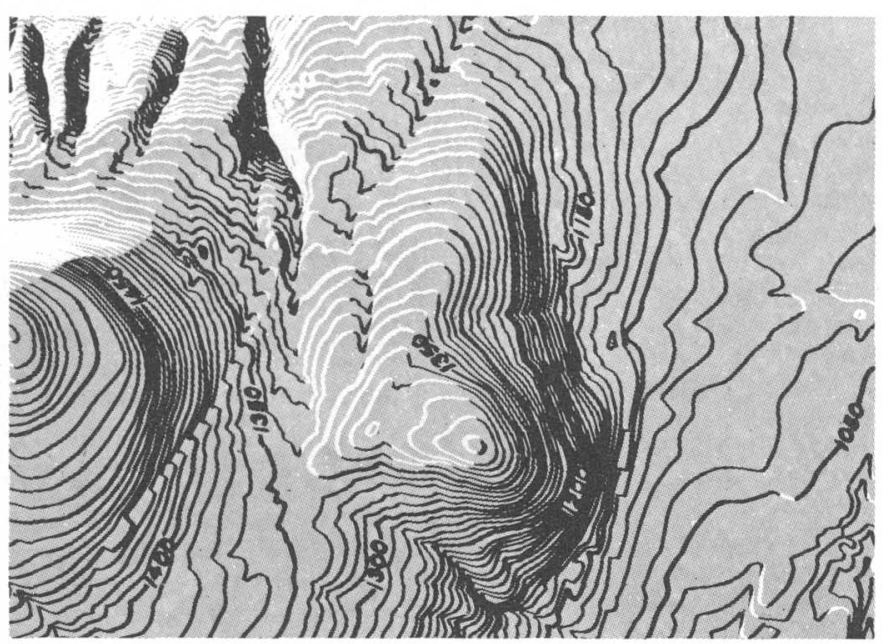

A

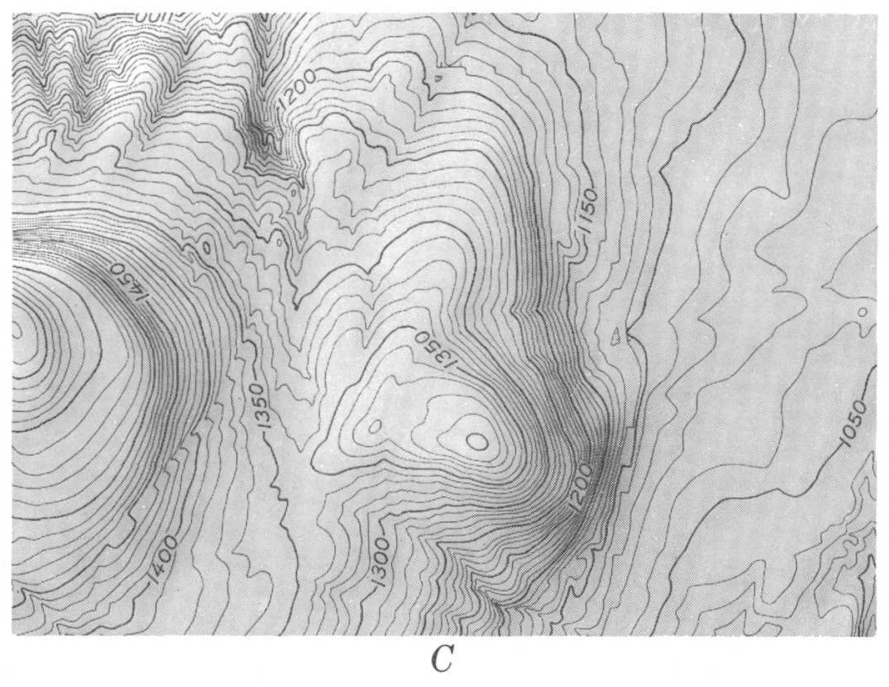

the mask, the enhanced contours, and a 40-percent screen are combined on a film which conveys a three-dimensional illusion (fig. $4 A$ ).

The composite is then used as copy for further processing into a more conventional shaded-relief form that resembles a hand rendering by airbrush (fig. $4 B$ ). In this procedure, continuous-tone film is exposed through a sandwich of the composite copy, a translucent diffuser, and a 0.1 -inch transparent spacer. Thus, the varying tones on the illuminated and shaded slopes are effectively blended with the background tint. The resultant shadings can be reproduced in halftone and overprinted on the topographic map (fig. $4 C$ ).

Further relief-shading experiments with maps of other scales and formats are in progress. Hopefully, the technique will assist us in producing more economical, but satisfactory, relief shading. In particular, we are anxious to determine if these semiautomatically generated products are practical for use on orthophotomaps and on 1:500,000-scale State maps.

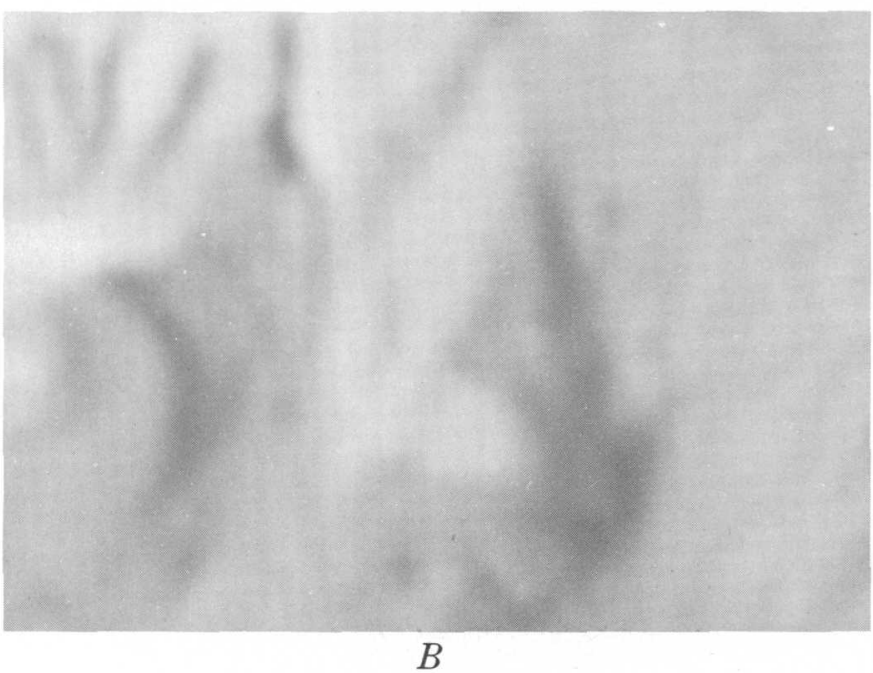

Figure 4.-Steps in photomechanical relief shading. $A$. Enhanced contours combined with an illumination mask. $B$. Enhanced contour lines blended by diffusion. $C$. Photomechanically generated shaded relief overprinted on contour lines.

\section{CONCLUSION}

In view of the present state of the art in cartographic equipment and techniques and the trend toward new cartographic products, additional research, experimentation, design, and testing of photomechanical devices and their products are both desirable and necessary. Photomechanical automation has been proved to be feasible, and the potential of this field should not be overlooked because of the rapid advances being made in automation by digital techniques. 


\title{
FORMATION OF JOINTS IN BEDROCK BY MOVING GLACIAL ICE
}

\author{
By FRANK W. TRAINER, Albuquerque, N.M.
}

\begin{abstract}
The orientation of joints in igneous and sedimentary rocks was measured at 21 localities in California, Maine, and New York to investigate the hypothesis that glaciation may open joints in bedrock. A summary of strikes of all joint sets shows the following pattern relative to the direction of glacial advance: two sets, thought to be extension joints, flank the direction of advance and are separated from it by about $10^{\circ}$; two sets, thought to be shear joints, flank the direction of advance by about $40^{\circ}$; and two sets, thought to be release joints, are about $70^{\circ}$ to $80^{\circ}$ from the direction of advance, or nearly perpendicular to the extension joints. An average of five joint sets, including three or four in this pattern, was found at each locality. The joints are believed to have been opened, in response to stress applied by the moving ice, along preexisting zones of weakness (potential regional joints) in the rock. Some new joints may have formed where no such zone was present near the position required for fracture under the applied stress. Additional investigation of the hypothesis is desirable because of its possible bearing on glacial erosion by quarrying, on interpretation of joint patterns in glaciated regions, and on the nature of aquifers in glaciated bedrock.
\end{abstract}

Several observers have interpreted jointing in glaciated rock as an effect of the glaciation. Lewis (1954, p. 418-419), Battey (1960, p. 8-9), and Linton (1963, p. 17-18) suggested that sheeting, formed as a result of dilatation after glacial erosion, has contributed significantly to deep glacial erosion in mountain valleys in Norway. Johnston $(1964$, p. 27) suggested that bedding joints in horizontal sedimentary rocks in western New York were opened or expanded as a result of pressure release during deglaciation.

Nonsheeting joints, vertical or steeply dipping, are common in many glaciated terrains. One can infer that they are regional joints, inherited from the preglacial history of the rock, which are present as either potential or incipient fractures to considerable depth. Kupsch $(1955,1965)$ described jointing in boulders in a deposit of glacial drift-jointing which he attributed to stress applied by glacial ice that had moved across the deposit. At least two other references have been made to the possible role of glacial stress in opening bedrock joints. Chapman (1958, p. 557) concluded that glacial ice shove had opened some joints in granite on Mount Desert Island, Maine. Yatsu (1966, p. 45) listed compression failure due to glacial action in a table of geomorphic agents and types of destruction but did not elaborate this interpretation.
This report presents the hypothesis that stress applied by a moving glacier opens joints in the underlying bedrock. Most of these joints are believed to have formed along preexisting zones of weakness whose positions are near those required for fracturing under the applied stress, but it is suggested that new joints may be formed in sound rock where older zones of weakness do not occur near the required positions.

Acknowledgments.-The assistance of John T. Collier, David M. Hopkins, and Robert A. Loney, through their discussion and review of this study and report, is gratefully acknowledged.

\section{SOURCES OF DATA}

The orientations of joints were measured at 21. localities: eight in granite or rhyolite in the Sierra Nevada in east-central California; three in granite on Mount Desert Island, Maine; and 10 in sandstone or carbonate rock in New York. Table 1 summarizes the observations, and figure 1 shows the locations of the areas in which data were obtained.

The eastern part of the Sierra Nevada is characterized by a regional system of steeply dipping conjugate joints (Bateman and Wahrhaftig, 1966, p. 121-122). At most places two principal joint sets can be identified; they are nearly at right angles, one striking northeast and one northwest. In this investigation joints were studied in two parts of the range: in Yosemite National Park (No. 1 in table 1), and near Interstate Highway 80, which crosses the crest of the range near Donner Pass in the region between Sacramento, Calif., and Reno, Nev. (Nos. 2-8, table 1).

On Mount Desert Island, Maine, two or three sets of well-developed joints and one to three sets of poorly developed joints are commonly present at a given locality; the sets which are best developed are believed to be those whose orientation relative to the local topography or to sheeting surfaces is favorable for dilatation (Chapman, 1958, p. 556-557). As part of the present study the orientations of joints were measured at three places at or near the summit of Cadillac Mountain (Nos. 9-11.).

Joints were studied in horizontally bedded sedimentary rocks in western New York (Nos. 12-16), in southeastern New York (17-20), and near the south end of Lake Cham- 
Table 1.-Joint sets identified on contoured equal-area plots, and other data, for 21 localities in California, New York, and Maine

\begin{tabular}{|c|c|c|c|c|c|}
\hline $\begin{array}{l}\text { Locality } \\
\text { No. } \\
\text { (fig. 1) }\end{array}$ & $\begin{array}{c}\text { Location }^{i} \\
\text { (long W., lat N.) }\end{array}$ & $\begin{array}{l}\text { Number } \\
\text { of } \\
\text { joints }\end{array}$ & Rock $^{2}$ & $\begin{array}{l}\text { Average } \\
\text { strike } \\
\text { of } \\
\text { scratches }\end{array}$ & $\begin{array}{l}\text { Average strike and dip of joint sets }{ }^{3} \\
\text { (degrees) }\end{array}$ \\
\hline \multicolumn{6}{|c|}{ California } \\
\hline 1... Tuolumne Meadows. & $\begin{array}{r}119^{\circ} 20^{\prime} 43^{\prime \prime}, \\
37^{\circ} 52^{\prime} 24^{\prime \prime}\end{array}$ & 210 & G & N. $76 \mathrm{~W}$. & $\begin{array}{l}\text { N. } 84 \text { W., } 88 \text { NE. (5); N. } 60 \text { W., } 80 \text { SW. (5); N. } 44 \text { W., } 90(5) ; \\
\text { N. } 8 \text { E., } 87 \text { SE (4); N. } 25 \text { E., } 90 \text { (8) R; N. } 42 \text { E., } 35 \text { NW. (2). }\end{array}$ \\
\hline $2 \ldots$ Long Lake ........ & $\begin{array}{r}120^{\circ} 25^{\prime} 52^{\prime \prime}, \\
39^{\circ} 17^{\prime} 37^{\prime \prime}\end{array}$ & 99 & G. & N. 15 E. & $\begin{array}{l}\text { N. } 66 \text { W., } 80 \text { NE. (9) R; N. } 40 \text { W., } 65 \text { SW. (4); N. } 15 \text { E., } \\
77 \text { SE. }(8) ; \text { N. } 45 \text { E., } 90(6) \text { R; N. } 52 \text { E., } 47 \text { NW. (2); N. } 70 \text { E., } \\
90(6) \text {. }\end{array}$ \\
\hline 3... Hill near Long Lake. & $\begin{array}{r}120^{\circ} 25^{\prime} 18^{\prime \prime} \\
39^{\circ} 18^{\prime} 00^{\prime \prime}\end{array}$ & 100 & G & N. $8 \mathrm{~W}$. & $\begin{array}{l}\text { N. } 75 \text { W., } 80 \text { NE. (14) R; N. } 62 \text { W., } 78 \text { SW. (1.0) R; N. } 64 \text { E., } \\
72 \text { NW. (11). }\end{array}$ \\
\hline 4. . . Near Palisade Lake .. & $\begin{array}{r}120^{\circ} 24 \cdot 38^{\prime \prime}, \\
39^{\circ} 18 \cdot 244^{\prime \prime}\end{array}$ & 112 & $\mathbf{R}$ & N. 1 E. & $\begin{array}{l}\text { N. } 88 \text { W., } 88 \text { NE. (5); N. } 41 \text { W., } 90(8) \text { R?; N. } 0 \text { E., } 90(6) ; \\
\text { N. } 13 \text { E., } 82 \text { NW. (4); N. } 30 \text { E., } 90(5) ; \text { N. } 58 \text { E., } 90(9) \text { R?. }\end{array}$ \\
\hline $5 \ldots$. Cold Springs. . . . . & $\begin{array}{r}120^{\circ} 27^{\prime} 56^{\prime \prime} \\
39^{\circ} 19^{\prime} 01^{\prime \prime}\end{array}$ & 100 & G & N. $66 \mathrm{E}$. & $\begin{array}{l}\text { N. } 35 \text { W., } 90(12) \text { R; N. } 18 \text { W., } 90 \text { (12); N. } 22 \text { E., } 75 \text { NW. (5); } \\
\text { N. } 50 \text { E., } 72 \text { SE. (7) R; N. } 75 \text { E., } 80 \text { SE. (4). }\end{array}$ \\
\hline $\begin{array}{l}6 \ldots \text { Lower Lola } \\
\text { Montez Lake. }\end{array}$ & $\begin{aligned} 120^{\circ} 25^{\prime} 23^{\prime \prime} \\
39^{\circ} 21^{\circ} 00^{\prime \prime}\end{aligned}$ & 102 & G & N. $2 \mathrm{E}$. & $\begin{array}{l}\text { N. } 82 \text { W., } 85 \text { SW. (3); N. } 58 \text { W., } 90 \text { (5) R; N. } 20 \text { W., } 72 \text { SW. (8); } \\
\text { N. } 35 \text { E., } 63 \text { NW. (3); N. } 55 \text { E., } 65 \text { SE. (5) R?; N. } 75 \text { E., } 90 \text { (3). }\end{array}$ \\
\hline $7 \ldots$ Euer Saddle .... & $\begin{aligned} & 120^{\circ} 20^{\prime} 28^{\prime \prime} \\
& 39^{\circ} 20^{\prime} 45^{\prime \prime}\end{aligned}$ & 100 & G & N. $48 \mathrm{~W}$. & $\begin{array}{l}\text { N. } 47 \text { W., } 60 \text { NE. (9) R?; N. } 27 \text { W., } 78 \text { SW. (8); N. } 20 \text { E., } 90(9) \text {; } \\
\text { N. } 57 \text { E., } 83 \text { NW. (11) R?; N. } 85 \text { E., } 90(2) \text {. }\end{array}$ \\
\hline $8 \ldots$. . Donner Pass ....... & $\begin{aligned} 120^{\circ} 19^{\prime} 37^{\prime \prime} \\
39^{\circ} 19^{\prime} 06^{\prime \prime}\end{aligned}$ & 100 & $\mathrm{G}$. & N. $73 \mathrm{E}$. & $\begin{array}{l}\text { N. } 66 \text { W., } 90(7) \text { R; N. } 45 \text { W., } 83 \text { SW. (7); N. } 30 \text { W.,90 (7); } \\
\text { N. } 15 \text { W., } 90(10) \text {; N. } 5 \text { W., } 90(8) \text {; N. } 20 \text { E., } 90(4) \text { R?; } \\
\text { N. } 55 \text { E., } 70 \text { NW. (3); N. } 75 \text { E., } 78 \text { NW. (5). }\end{array}$ \\
\hline \multicolumn{6}{|c|}{ Maine } \\
\hline 9 ... Mt. Desert Island . & $\begin{array}{l}\text { Summit, } \\
\text { Cadillac Mtn. }\end{array}$ & 108 & G & N. $27 \mathrm{~W}$. & $\begin{array}{l}\text { N. } 85 \text { W., } 88 \text { NE. }(5) ; \text { N. } 60 \text { W., } 90(8) ; \text { N. } 20 \text { W., } 89 \text { NE. }(6) \text {; } \\
\text { N. } 0 \text { E., } 88 \text { E. }(6) ; \text { N. } 42 \text { E., } 88 \text { NW. }(8) .\end{array}$ \\
\hline $10 \ldots$ do. & $\begin{array}{l}\text { Ridge NE. of } \\
\text { summit. }\end{array}$ & 1.25 & G & N. $27 \mathrm{~W}$. & $\begin{array}{l}\text { N. } 89 \text { W., } 90(11) ; \text { N. } 38 \text { W., } 80 \text { SW. (5); N. } 10 \text { W., } 90(8) \text {; } \\
\text { N. } 15 \text { E., } 85 \text { SE. (8). }\end{array}$ \\
\hline $11 \ldots$ do. & $\begin{array}{l}\text { W. face moun- } \\
\text { tain, near } \\
\text { summit. }\end{array}$ & 1.00 & G & N. $18 \mathrm{~W}$. & $\begin{array}{l}\text { N. } 75 \text { W., } 85 \text { SW. (6); N. } 28 \text { W., } 90 \text { (8); N. } 20 \text { E., } 90 \text { (7); N. } 80 \text { E., } \\
88 \text { NW. (13). }\end{array}$ \\
\hline \multicolumn{6}{|c|}{ New York } \\
\hline $12 \ldots$. Pekin . & $\begin{array}{l}\text { Quarry } 2.0 \text { miles } \\
\text { NW. of Pekin. }\end{array}$ & 146 & $\mathrm{~S}$ & N. 75 E. & $\begin{array}{l}\text { N. } 38 \text { W., } 88 \text { SW. (18) R; N. } 23 \text { W., } 82 \text { SW. (5); N. } 12 \text { E., } 90(4) \text {; } \\
\text { N. } 84 \text { E., } 87 \text { SE. (10) R. }\end{array}$ \\
\hline 13. . Lockport . & Outwater Park & 91 & $\mathrm{~L}$ & N. $41 \mathrm{E}$. & $\begin{array}{l}\text { N. } 76 \text { W., } 78 \text { SW. (2); N. } 58 \text { W., } 87 \text { NE. (24) R; N. } 32 \text { W., } \\
90(6) \text { R?; N. } 3 \text { E., } 87 \text { SE. (4); N. } 23 \text { E., } 83 \text { SE. (3); N. } 81 \text { E., } \\
86 \text { NW. (16) R. }\end{array}$ \\
\hline $14 \ldots \ldots$ do & Gooding Street & 143 & $\mathrm{~L}$ & N. $11 \mathrm{E}$. & $\begin{array}{l}\text { N. } 58 \text { W., } 88 \text { NE. (12) R; N. } 9 \text { E., } 87 \text { NW. (4); N. } 22 \text { E., } 90(2) \text {; } \\
\text { N. } 53 \text { E., } 75 \text { NW. (3); N. } 87 \text { E., } 88 \text { SE. (20) R. }\end{array}$ \\
\hline $15 \ldots$. do & $\begin{array}{l}\text { Quarry, Fron- } \\
\text { tier Stone } \\
\text { Products. }\end{array}$ & 317 & $\mathrm{~L}$ & N. $35 \mathrm{E}$. & N. 45 W. R; N. 5 W; N. 20 E; N. 80 E. R \\
\hline 16 ... Gasport & Bolton Road & 115 & $\mathrm{~L}$ & N. $23 \mathrm{E}$. & $\begin{array}{l}\text { N. } 78 \text { W., } 88 \text { NE. (25); N. } 35 \text { W., } 88 \text { NE. (5) R?; N. } 15 \text { W., } \\
90(4) ; \text { N. } 32 \text { E., } 88 \text { NW. (8); N. } 87 \text { E., } 88 \text { NW. (8) R. }\end{array}$ \\
\hline 17... McClure .. & $\begin{array}{l}\text { Highway } 17 \text {, } \\
4.7 \text { miles } W \text {. }\end{array}$ & 127 & $\mathrm{~S}$ & N. $21 \mathrm{E}$. & $\begin{array}{l}\text { N. } 85 \text { W., } 83 \text { SW. (1.2); N. } 60 \text { W., } 88 \text { SW. (2); N. } 50 \text { W., } \\
78 \text { NE. }(2) \text {; N. } 8 \text { E., } 88 \text { NW. (16); N. } 35 \text { E., } 80 \text { SE. (2); } \\
\text { N. } 48 \text { E., } 75 \text { SE. (3); N. } 70 \text { E., } 50 \text { SE. (2). }\end{array}$ \\
\hline $18 \ldots$. Otego .. & $\begin{array}{l}\text { Highway } 7,2.3 \\
\text { miles SW. }\end{array}$ & 93 & $S$ & N. 57 E. & $\begin{array}{l}\text { N. } 65 \text { W., } 73 \text { SW. }(4) \text {; N. } 30 \text { W., } 78 \text { SW. }(4) \text {; N. } 5 \text { W., } \\
75 \text { NE. (4); N. } 15 \text { E., } 90(2) \text {; N. } 66 \text { E., } 78 \text { SE. (7); N. } 81 \text { E., } \\
67 \text { SE. (9). }\end{array}$ \\
\hline 19 ... Windham & $\begin{array}{l}\text { Highway } 23 \text {, } \\
1.6 \text { miles } E \text {. }\end{array}$ & 80 & S & N. $50 \mathrm{E}$. & $\begin{array}{l}\text { N. } 66 \text { W., } 80 \text { NE. (10); N. } 16 \text { E., } 55 \text { NW. (2); N. } 38 \text { E., } \\
80 \text { SE. }(22) \text {. }\end{array}$ \\
\hline 20 . . Kingston & $\begin{array}{l}\text { Highway } 209 \\
\text { at S. edge of } \\
\text { village. }\end{array}$ & 94 & $\mathrm{~L}$ & N. $29 \mathrm{E}$. & N. 82 W., 88 SW. (5); N. 30 W., 87 SW. (2); N. 3 E., 88 NW. (20). \\
\hline $21 \ldots$ Crown Point & $\begin{array}{l}\text { Shore, Lake } \\
\text { Champlain, } \\
\text { near bridge, } \\
\text { Highway } 8 \text {. }\end{array}$ & 84 & $\mathrm{~L}$ & N. $19 \mathrm{E}$. & $\begin{array}{l}\text { N. } 88 \text { W., } 88 \text { NE. (15); N. } 60 \text { W., } 85 \text { NE. (6); N. } 45 \text { W., } 88 \text { SW. (4); } \\
\text { N. } 22 \text { W., } 88 \text { NE. (2); N. } 13 \text { E., } 80 \text { SE. (6). }\end{array}$ \\
\hline
\end{tabular}

\footnotetext{
${ }^{1}$ Where adequate, a brief verbal description is given instead of longitude and latitude.

${ }^{2} \mathrm{G}$, granite; R, rhyolite; L, carbonate rock; $S$, sandstone.

${ }^{3}$ Concentration (in percent) in parentheses; $R$, regional joint set.

${ }^{4}$ Joints observed on horizontal rock surface, plotted as vertical joints.
} 

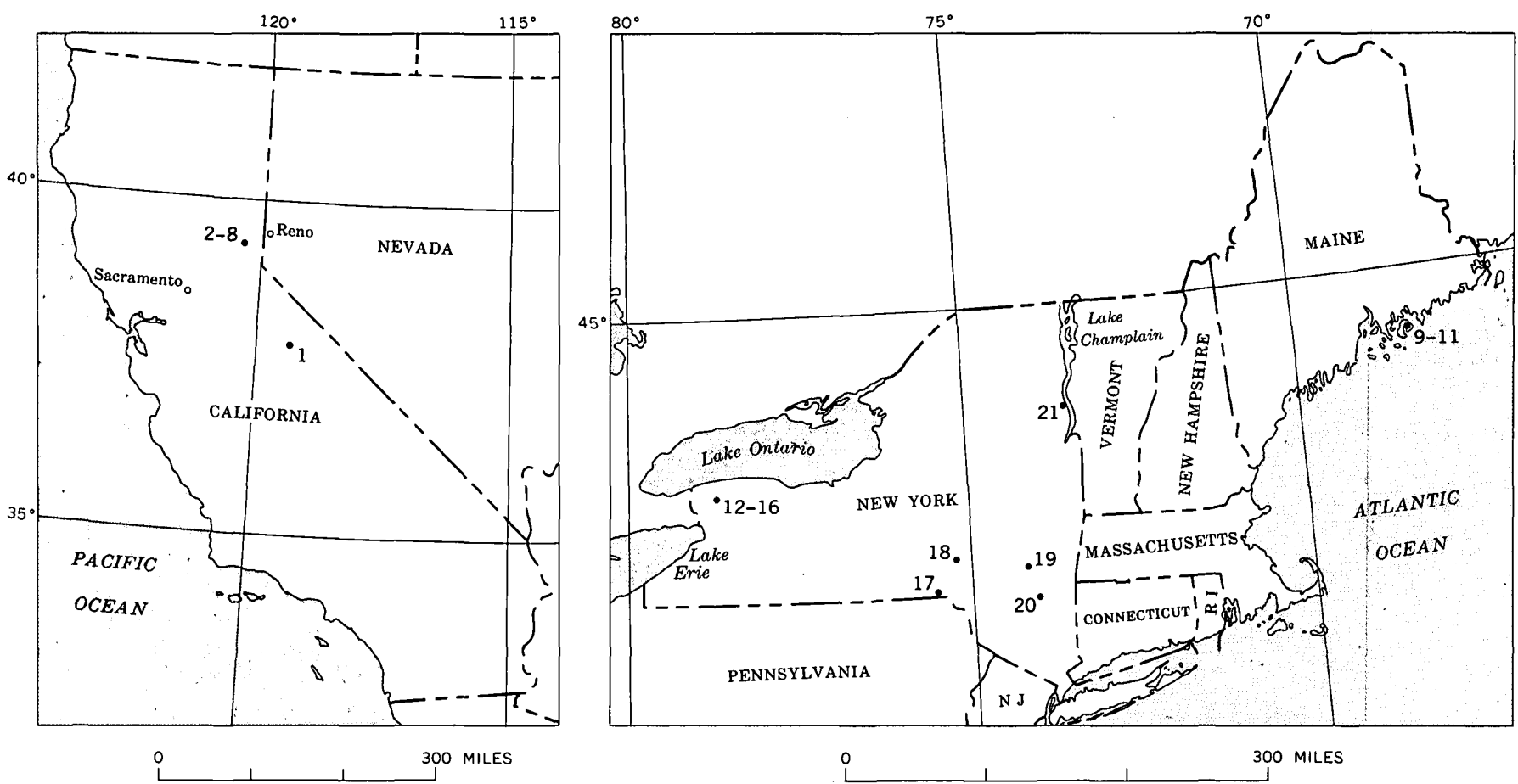

Figure 1.-Locations of areas in California, Maine, and New York where orientations of joints were measured.

plain (21.). In western New York the joints are in the Lockport Dolomite (Silurian) and in sandstone in the Albion Group (Silurian). Two sets of regional joints are present; they strike about N. 81. E. and N. 47 W. In southeastern New York three regional joint sets have been recognized (Parker, 1942); two, approximately perpendicular, whose strikes shift progressively in a clockwise direction as the observer moves eastward across northern Pennsylvania and southern New York, and a third set which strikes northeast throughout the region. Joints measured in this region as part of this study are in sandstones of the Katsberg Formation of Chadwick (1.933) and of the Genesee Formation, and in Onondaga Limestone, all of Devonian age. Near Lake Champlain the joints are in limestone of the Chazy Group.

\section{METHODS OF STUDY}

The strike and dip of joints were measured at each of the 21 . localities. Samples represent from 80 to 317 joints; at most localities a sample of about 100 joints was measured. In the granites only steeply dipping joints that are at a high angle to the sheeting were measured; near-horizontal sheeting is present at most of these places. In the sedimentary rocks both near-horizontal bedding joints and near-vertical joints were measured, but the bedding joints constitute only a small proportion of the total. At each locality, observations were made in the smallest practicable area. At most localities a hundred joints were found within a tract of land surface of 2,000 to $5,000 \mathrm{sq}$ ft (about 200 to $500 \mathrm{~m}^{2}$ ) or in a roadcut 200 to 300 leet (about 65 to $1.00 \mathrm{~m}$ ) long.
The strikes of glacial scratches and grooves on the bedrock surface were measured in order to determine the last direction of glacier movement.

Regional joints were identified through such criteria as length, depth, and continuity (most clearly seen in the Sierra Nevada and on Mount Desert Island); relative frequency at a locality; and similarity of strikes with those of joints at nearby localities. Joints were also measured at several localities which are not listed in table 1 . because glacial scratches were not found; some of these data were used in identification of the sets of regional joints.

Observations were plotted and joint sets identified on a Schmidt or equal-area net using the lower hemisphere.

\section{PATTERN OF JOINT SETS}

The distribution of strikes of joints is broadly similar at many localities. Thus, it is common to find joints which strike along or at a small angle to the direction of glacial advance, joints which are at a large angle to the direction of advance, and joints which are near an angle of $45^{\circ}$ with respect to the direction of advance. Figure $2 A$, which represents the orientation of joints in granite at one locality in the Sierra Nevada, illustrates this pattern. Five sets of joints are identified in the diagram; their average strikes are N. $35^{\circ}$ W., N. $18^{\circ}$ W., N. $22^{\circ}$ E., N. $50^{\circ}$ E., and N. $75^{\circ}$ E. Two sets (N. $35^{\circ}$ W. and N. $50^{\circ}$ E.) are believed to be regional joints. At this locality the direction of ice movement was along the line N. $66^{\circ} \mathrm{E}$. If the diagram is rotated so that the line of glacial advance becomes N. $0^{\circ}$ E., the strikes of the five joint sets become N. $79^{\circ} \mathrm{E}$., N. 

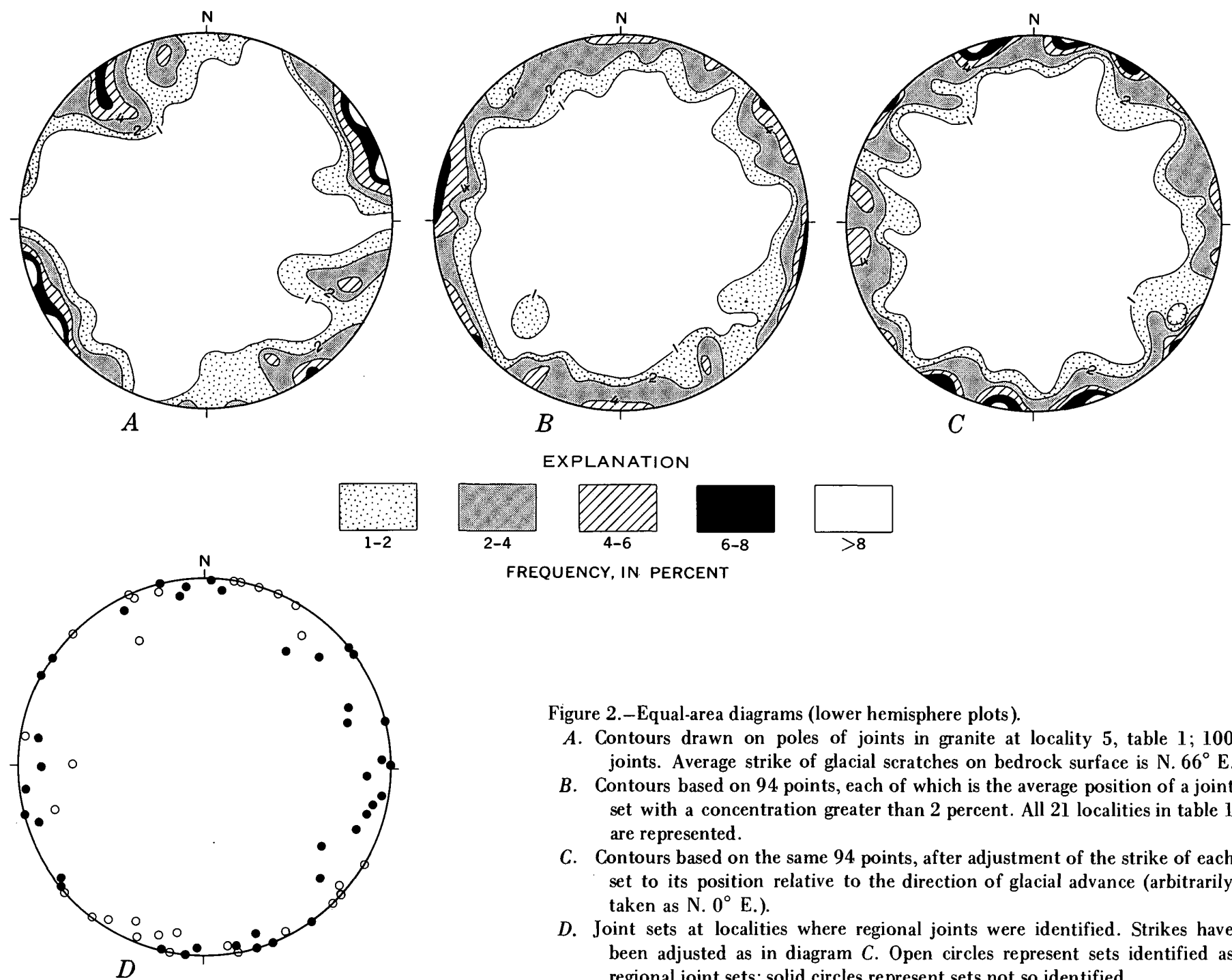

Figure 2.-Equal-area diagrams (lower hemisphere plots).

$A$. Contours drawn on poles of joints in granite at locality 5 , table $1 ; 100$ joints. Average strike of glacial scratches on bedrock surface is N. $66^{\circ} \mathrm{E}$.

$B$. Contours based on 94 points, each of which is the average position of a joint set with a concentration greater than 2 percent. All 21 localities in table 1 are represented.

C. Contours based on the same 94 points, after adjustment of the strike of each set to its position relative to the direction of glacial advance (arbitrarily taken as N. $0^{\circ}$ E.).

D. Joint sets at localities where regional joints were identified. Strikes have been adjusted as in diagram $C$. Open circles represent sets identified as regional joint sets; solid circles represent sets not so identified.

$84^{\circ}$ W., N. $44^{\circ}$ W., N. $16^{\circ}$ W., and N. $9^{\circ}$ E., respectively.

A total of 107 joint sets was identified in the equal-area diagrams for the 21 localities. From three to eight sets were found at individual localities. In order to see the distribution of joint sets more clearly, summary diagrams (fig. $2 B, C$ ) were prepared by an extension of a method used by Spencer (1959, p. 480-481). The mean position of each joint set having a concentration greater than 2 percent ( 94 of the 107 sets) was plotted as a pole on each of the two equal-area diagrams. Figure $2 B$ is a summary diagram for the 94 points, plotted in their observed positions with respect to geographic north. Figure $2 C$ is a summary diagram for these 94 points in which their strikes have been rotated to positions relative to the direction of glacial advance (taken arbitrarily as N. $0^{\circ}$ E.).

The summary diagram of adjusted poles (fig. $2 C$ ) reveals seven well-defined concentrations whose average strikes relative to the direction of glacial advance $\left(\mathrm{N} .0^{\circ} \mathrm{E}\right.$.) are $\mathrm{N} .9^{\circ} \mathrm{W}$., N. $8^{\circ}$ E., N. $40^{\circ}$ E., N. $40^{\circ}$ W., N. $58^{\circ}$ W., N. $72^{\circ}$ E., and N. $80^{\circ} \mathrm{W}$. A diagram (not shown) similar to figure $2 C$ was prepared by plotting the percentage-concentration value of each of the 94 sets, rather than a single point having weight equal to that of every other point. Contouring this plot eliminated the concentration at $\mathrm{N} .58^{\circ} \mathrm{W}$.; the remaining six concentrations of figure $2 C$ were duplicated almost precisely. Each of these concentrations exhibits a range of about $15^{\circ}$ to $20^{\circ}$, with most of the points falling within a span of $10^{\circ}$ or less.

The summary diagram of unadjusted poles (fig. $2 B$ ) was prepared as a semiquantitative test of the significance of the apparent orderly arrangement of concentrations in figure $2 C$. It seems possible that if two or more diagrams, each of which had several well-defined joint sets, were rotated through random angles and then combined, the resulting summary diagram might show clearly defined concentrations. The pattern of concentrations in the adjusted plot is much more orderly than that in the unadjusted plot. This common pattern in the adjusted diagram for the 21 samples, which represent unlike rock types and structural histories, suggests a similar 
response of these rocks to the stress applied by moving ice.

How many of the six joint sets are likely to be found at a single locality? Three arbitrary ranges of average strike, based on examination of figure $2 C$, were used to estimate the frequency of occurrence of these joint sets. (1) At 16 of the 21. localities studied there is one joint set whose average strike is within $15^{\circ}$ of the direction of glacier movement. At one locality there are two such sets, and at four localities there are none. (2) At nine of the 21 localities there is one set whose average strike is $35^{\circ}-45^{\circ}$ from the direction of advance; at two localities there are two such sets, one to each side, and at 10 localities there are no sets in this range. (3) At 11 of the 21. localities there is one set whose average strike is $65^{\circ}-85^{\circ}$ to one side of the direction of advance, and at eight localities there are two sets, one to each side. There is thus a high degree of similarity in the patterns of joints at the localities studied.

\section{INTERPRETATION OF JOINT PATTERN}

Kupsch (1955, p. 332-336) found three sets of joints in the boulder deposit that he studied. Two near-vertical sets, each of which strikes about $45^{\circ}$ to one side of the direction of glacial advance, were interpreted as shear joints. The third nearvertical set, approximately parallel to the direction of advance, was interpreted as a set of extension joints. In the present study the writer concludes tentatively that joints in these glaciated areas include two sets of shear joints which flank the direction of ice advance and strike at about $40^{\circ}$ to it, two sets of extension joints which flank the direction of advance and strike within about $10^{\circ}$ of it, and two sets of release joints which are nearly perpendicular to the sets of extension joints. There commonly is considerable departure from this idealized average pattern. As was noted in the preceding section, at many localities some of these sets are missing or are poorly represented. Nonetheless, if one considers the nonhomogeneity of the rocks, the range in direction of application of the glacial stress (at least $10^{\circ}$ to $15^{\circ}$ at many localities), and the unknown effect of topography on the glacial stress, the agreement of the strikes of observed joint sets with those expected on the basis of theory is considered satisfactory.

Observations by Kupsch $(1955$, p. $330 ; 1965$, p. 114), which show that individual joints in boulders in a drumlin may extend through adjacent boulders, leave no doubt that those joints are related to stress applied by the moving glacier; they are not preglacial. Kupsch $(1955$, p. 336) concluded that the jointing occurred when the glacier advanced across a frozen mass of sediment and interstitial ice. Where joints cut bedrock rather than boulders, it is possible that the glaciation opened joints along preexisting zones of weakness, and identification of the regional joints is therefore necessary. The data obtained in the present study are not adequate to show whether all the joints were opened along old zones of weakness in the rock. From two to several sets of regional joints are probably present at each of the localities studied, and it seems likely that joints of any of these sets, if near the positions required for fracture, could be opened as a result of glacial stress. However, the regional joints could not be identified at all 21 localities. Figure $2 D$ is a plot of the poles of all joint sets for the localities at which regional joints were recognized. (Strikes of the joint sets have been adjusted to the direction of glacial movement.) It is clear that each concentration of joint sets in figure $2 C$ is a regional set in at least some of the localities studied, and that the possible role of glacial stress in forming new joints in sound rock cannot be evaluated with the available evidence. The abundance of joint sets at most localities studied, however, favors the interpretation that some were formed in sound rock and do not lie along preexisting zones of weakness.

It is desirable that further tests of the hypothesis of the glacial opening of joints, and of the possible role of new (nonregional) joints in this process, should include comparison of joint patterns and abundance in similar rocks in adjacent glaciated and unglaciated regions, and an attempt to relate characteristics of the jointing to such factors as slope of the bedrock surface and thickness of the glacier. One such study could well be made in the Appalachian Plateaus region, which is discussed briefly in the next section.

\section{SOME IMPLICATIONS OF GLACIAL JOINTING}

The writer believes that the foregoing hypothesis warrants further examination and testing because the formation of fractures in this way would be a significant consideration in several types of studies. Three of these are noted briefly below.

\section{Geomorphology}

At many places sheeting is an incomplete answer to the problem of why bedrock is susceptible to glacial quarrying in mountainous regions. Other joints, at high angles to the sheeting, are required to break the rock into blocks which can be removed by plucking. Joints opened by moving glacial ice would serve this function and thus would facilitate glacial erosion.

Locality 1 in table 1 is on a small ice-rounded hill. Visible joints are sparse on the adjacent ice-scoured rock surface of low relief. On the hill, however, joints are abundant. Six sets of nonsheeting joints, all near the vertical, were found on the gently rounded upstream end of the hill. Three of these sets (those with strikes N. $84^{\circ}$ W., N. $25^{\circ}$ E., and N. $42^{\circ}$ E.) were also found on the cliffy downstream end of the hill. There, with sheeting joints and an additional near-vertical set, they facilitated partial destruction of the hill by glacial quarrying.

\section{Structural geology}

If joints were opened as a result of glacial stress their presence in the bedrock of a glaciated region would complicate 
tectonic interpretation of the joint pattern, particularly if the joints included some unrelated to preglacial stresses.

The Appalachian Plateaus province in western New York and Pennsylvania is a region where reexamination of the joints would be of interest in light of the hypothesis of glacial jointing. In addition to the report by Parker (1942) already cited, many other reports treat the joints in this region. (See, for example, Badgley, 1965, p. 101-103; de Sitter, 1956, p. 125-126; Muehlberger, 1961; Nickelsen and Hough, 1967; and Wood and others, 1969.) A striking feature of Parker's report is his observation that the north-trending set of joints in this region is double, consisting of two subsets whose average strikes are separated by about $19^{\circ}$. Several of the writers cited above have discussed and reinterpreted this observation. Nickelsen and Hough $(1967$, p. 622) noted that few of the exposures they studied in Pennsylvania, and few they observed during reconnaissance in New York, show these acutely intersecting joints; they believe that the few acutely intersecting sets found represent "overprinting" of sets from adjacent areas, in each of which one set dominates. This interpretation is reasonable in light of the fact that Parker's diagrams do not represent single localities but are summaries for 15-minute quadrangles based on a few observations at each of many localities. But it seems less reasonable in light of the large region of southern New York covered by Parker's observations. Under an alternative explanation, one member of Parker's paired joints may have been opened by moving ice at places where the direction of glacial advance was at a large acute angle to the strike of a single north-trending set of regional joints.

\section{Ground water}

Substantial changes in the occurrence of shallow ground water have occurred in many glaciated regions as a result of the glaciation. One of the most significant of these changes has been the removal of much or all of the layer of broken and weathered rock which formerly covered the bedrock, and the deposition of drift in its place. Quantitative change in the hydrologic character of the bedrock has probably been greatest in limestone and dolomite, where the solution-riddled upper part of the rock has been partly or completely removed, leaving an eroded surface of fresh and relatively impermeable rock.

Field studies of ground water in some glaciated regions of carbonate rock have shown, however, that the uppermost part of the glacially eroded rock has appreciable secondary permeability. In some of these regions sufficient evidence is available from drillers' logs to show that there are few cavernous openings or other solution-widened joints in the rock; evidently the permeability is due to relatively unmodified fractures. Well records from glaciated carbonate-rock terrains in Michigan, Ohio, and New York (Norris, 1959; Sinclair, 1960; Trainer and Salvas, 1962; Vanlier, 1963) were examined to determine the depth of penetration of glaciated carbonate rock which is adequate to insure a domestic or farm water supply-probably one to a few gallons per minute, on the average. In the sample of 982 wells the median depth of penetration is about 24 feet; 44 percent of the wells penetrate 20 feet of rock, or less, and 25 percent penetrate 10 feet or less. These data, in light of the hypothesis of glacial jointing, suggest that a fracture zone of low to moderate permeability is typical of the upper part of the glaciated bedrock in these regions. The effect of deep glacial erosion of the carbonate rock is thought to have been the removal of the upper part of the rock, a karst aquifer of low to high permeability, and the substitution for it of a fractured-rock aquifer of low permeability.

This conclusion is of potential significance for its bearing on both water supply and waste disposal. Thus, we may conclude that a thin aquifer is likely to occur generally in the upper part of glaciated bedrock. Where covered by till it commonly is hydraulically confined, or artesian; where covered by washed drift it is more likely to be unconfined. It may generally be a source of small water supplies. But where the drift cover is both relatively permeable and thin, or where it is absent, this bedrock aquifer also provides a potential medium for the migration of substances derived from septic tanks and other sites for the disposal of wastes to the ground at shallow depth. For this reason protection of surface and near-surface material from disposal and from accidental spills of noxious substances is particularly important where glaciated bedrock is not covered by a thick layer of till which would serve to protect the aquifer from contamination.

\section{REFERENCES CITED}

Badgley, P. C., 1965, Structural and tectonic principles: New York, Harper and Row, 521 p.

Bateman, P. C., and Wahrhaftig, Clyde, 1966, Geology of the Sierra Nevada, p. 107-172 in Bailey, E. H., ed., Geology of northern California: California Div. Mines and Geology Bull. 190.

Battey, M. H., 1960, Geological factors in the development of. Veslgjuv-botn and Vesl-Skaubotn, p. 5-10 in Lewis, W. V., ed., Investigations on Norwegian cirque glaciers: Royal Geog. Soc., Research Ser., no. 4, 104 p.

Chadwick, G. H., 1933, Catskill as a geologic name: Am. Jour. Sci., 5th ser., v. 26, no. 155 , p. 479-484.

Chapman, C. A., 1958, Control of jointing by topography: Jour. Geology, v. 66, no. 5, p. 552-558.

de Sitter, L. U., 1.956, Structural geology: New York, McGraw-Hill Book Company, Inc., 552 p.

Johnston, R. H., 1964, Ground water in the Niagara Falls area, New York, with emphasis on the water-bearing characteristics of the bedrock: New York Water Resources Comm. Bull. GW-53, 93 p.

Kupsch, W. O., 1955, Drumlins with jointed boulders near Dollard, Saskatchewan: Geol. Soc. America Bull., v. 66, no. 3, p. 327-338. 1965, Jointing of boulders caused by flowing ice: Alberta Soc. Petroleum Geologists, 15th Ann. Field Conf. Guidebook, Pt. 1, Cypress Hills Plateau, p. 11.2-115.

Lewis, W. V., 1954, Pressure release and glacial erosion: Jour. Glaciology, v. 2, no. 11. p. 417-422.

Linton, D. L., 1963, The forms of glacial erosion: Inst. British Geographers Trans., Pub. 33, p. 1-28. 
Muchlberger, W. R., 1961, Conjugate joint sets of small dihedral angle: Jour. Geology, v. 69, p. 211-219.

Nickelsen, R. P., and Hough, V. D., 1967, Jointing in the Appalachian Plateau of Pennsylvania: Geol. Soc. America Bull., v. 78, no. 5, p. $609-630$.

Norris, S. E., 1959, The water resources of Madison County, Ohio: Ohio Dept. Nat. Res., Div. Water, Bull. 33, 63 p.

Parker, J. M., III, 1942, Regional systematic jointing in slightly deformed sedimentary rocks: Geol. Soc. America Bull., v. 53, p. 381-408.

Sinclair, W. C., 1960, Reconnaissance of the ground-water resources of Delta County, Michigan: Michigan Geol. Survey Prog. Rept. no. 24, 93 p.
Spencer, E. W., 1959, Geologic evolution of the Beartooth Mountains, Montana and Wyoming. Part 2. Fracture patterns: Geol. Soc. America Bull., v. 70, no. 4, p. 467-508.

Trainer, F. W., and Salvas, E. H., 1962, Ground-water resources of the Massena-Waddington area, St. Lawrence County, New York, with emphasis on the effect of Lake St. Lawrence on ground water: New York Water Resources Comm. Bull. GW-47, 227 p.

Vanlier, K. E., 1963, Ground water in Menominee County: Michigan Geol. Survey Water Inv. 2, $42 \mathrm{p}$.

Wood, G. H., Jr., Arndt, H. H., and Carter, M. D., 1.969, Systematic jointing in the western part of the Anthracite Region of eastern Pennsylvania: U.S. Geol. Survey Bull. 1271-D, 17 p.

Yatsu, Eiju, 1966, Rock control in geomorphology: Tokyo, Sozosha, $135 \mathrm{p}$. 


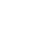




\title{
RAPID REACTION RATES BETWEEN WATER AND A CALCAREOUS CLAY AS OBSERVED BY SPECIFIC-ION ELECTRODES
}

\author{
BY WARREN W. WOOD, Lubbock, Tex.
}

\begin{abstract}
Specific-ion electrodes were used to simultaneously determine the activity changes of calcium, hydrogen, sodium, fluoride, and divalent ions when $50 \mathrm{~g}$ of a natural, untreated material containing calcium-rich mixed-layer illite-montmorillonite clay, quartz sand, and calcium carbonate was added to $250 \mathrm{ml}$ of natural Canadian River water containing $220 \mathrm{mg} / \mathrm{l} \mathrm{Na}$. Calcium and magnesium were displaced from the clay by the sodium; the exchanged and dissolved noncarbonate calcium precipitated as calcium carbonate, and the magnesium remained in solution. Fluoride entered into both a rapid reaction and a long-term reaction, indicating solution from the material. The $\mathrm{pH}$ decreased rapidly. The reactions for all observed ions, other than fluoride, were faster than the response time of their respective electrodes and were complete in less than one minute. Rapid solution of material containing calcium, magnesium, sodium, and fluoride was also observed when a duplicate sample of the earth material was added to distilled water; $\mathrm{pH}$ also changed rapidly in this mixture. These results suggest that many important water-rock reactions can be considered nearly instantaneous for purposes of digital modeling of the geochemical changes during artificial recharge.
\end{abstract}

This report presents data on the rate of ion exchange and mineral solution when distilled and high-sodium waters were mixed with a natural, untreated, clay-sized material. The laboratory experiment simulates a field condition that will be developed by artificial recharge through surface spreading on the southern High Plains of Texas.

Research for this paper was done as part of a study of chemical reactions occurring during artificial recharge when water is rapidly introduced into a chemically different environment. Predicting the quality of recharge water with time and space is a major goal of this recharge project. One phase of the study is an investigation of the rate at which these reactions occur. If they are slow-taking months or years-then the recharge water could be withdrawn before reactions proceed very far, and chemical changes would not be a problem. If the reactions are rapid, their effects must be considered; if the reactions are faster than flow velocity, they can be considered as instantaneous, which greatly simplifies digital modeling of the chemical system.

Field and laboratory experiments have been designed to test the rate of reaction of several important ions. One site where experiments will examine the chemical effects of recharge has been established north of Lubbock, Tex. The site has $27 \mathrm{~m}$ of saturated material overlain by $37 \mathrm{~m}$ of unsaturated material; it consists of a series of unconsolidated sands, silts, calcium-rich clays, and zones rich in calcium carbonate.

Untreated water from the Lubbock municipal supply will be the source of recharge water. This water, imported from the Canadian River north of Amarillo, Tex., is a sodium chloride, sodium sulfate water which contains approximately 1,000 $\mathrm{mg} / \mathrm{l}$ dissolved solids. Native ground water is a calcium magnesium bicarbonate water with less than $400 \mathrm{mg} / \mathrm{l}$ dissolved solids.

Malcolm and Kennedy (1969) used a monovalent-ion electrode to measure the rate of cation exchange on clay minerals that had been treated and prepared by grinding, blending, saturating with potassium chloride solution, and adjusting $\mathrm{pH}$. These authors observed exchange rates of $\mathrm{K}^{+}$for $\mathrm{Ba}^{+2}$ that were faster than the 3 -second response time of the electrode. The technique of using specific-ion electrodes to measure rapid chemical reactions was expanded for the present study to include several electrodes operating simultaneously. Untreated earth materials from the field-test site were used to duplicate natural conditions as nearly as possible.

A laboratory experiment using Canadian River water and earth materials taken from the field site was designed to measure the rate of ion exchange and mineral solution of five constituents. $\mathrm{Na}^{+}, \mathrm{H}^{+}, \mathrm{Ca}^{+2}$, and $\mathrm{Mg}^{+2}$ were selected because of the potential loss of hydraulic conductivity caused either by clay swelling upon the addition of sodium or by precipitation of calcium carbonate. $\mathrm{F}^{-}$was measured because the native water contains up to $10 \mathrm{mg} / \mathrm{l}$, and it is important to know if recharge water would acquire this concentration.

\section{EXPERIMENTAL METHODS}

The material used in this study was obtained from a clay layer approximately $1 \mathrm{~m}$ thick and $30 \mathrm{~m}$ below land surface in the Ogallala Formation. The clay was removed from a core taken near the Lubbock Regional Airport. The sample containing the clay was air dried at room temperature, mechanically disaggregated to pass through a 149-micron screen, and split into eight $50 \mathrm{~g}$ samples. X-ray analysis indicated that 65 percent of the sample was a mixed-layer illite-montmorillonite clay with 15 percent quartz, 15 percent calcium carbonate, 
and traces of potash and plagioclase feldspars. Magnetite is a dominant accessory mineral. The clay, which is deep red, has a cation-exchange capacity of approximately $49 \mathrm{meq} / 100 \mathrm{~g}$.

Canadian River water used in this experiment has the composition given in table 1 .

Table 1.-Average chemical analyses, in milligrams per liter, of water before and after batch tests

\begin{tabular}{|c|c|c|c|c|}
\hline \multirow[t]{2}{*}{ Constituent } & \multicolumn{2}{|c|}{$\begin{array}{c}\text { Canadian River water } \\
\text { (30 minutes contact time) } \\
\end{array}$} & \multicolumn{2}{|c|}{$\begin{array}{c}\text { Distilled water } \\
\text { (20 minutes contact time) }\end{array}$} \\
\hline & Initial & Final & Initial & Final \\
\hline Сa. ...... & 57 & 58 & 0.0 & 24 \\
\hline $\operatorname{Mg} \ldots \ldots \ldots$ & 23 & 46 & .0 & 12 \\
\hline $\mathrm{Na} \ldots .$. & 220 & 165 & .0 & 8.4 \\
\hline $\mathrm{HCO}_{3} \ldots \ldots$ & 191 & 160 & 2.4 & 53 \\
\hline $\mathrm{SO}_{4} \ldots \ldots$ & 230 & 235 & .0 & 15 \\
\hline $\mathrm{Cl} \ldots \ldots$ & 231 & 240 & .0 & 40 \\
\hline$F_{\ldots} \ldots \ldots$ & 1.0 & 4.2 & .0 & 2.0 \\
\hline $\mathrm{pH}$. & 7.85 & 7.70 & 5.62 & 8.28 \\
\hline
\end{tabular}

Orion $^{1}$ specific electrode model $92-20$ was used to determine calcium activity, Orion model $92-32$ was used to determine divalent cation activity, Orion 94-09 was used to determine fluoride activity, Orion 94-11 was used to determine sodium activity, and a Corning ${ }^{1}$ triple purpose glass electrode was used to determine $\mathrm{pH}$. Orion model 90-01 single junction reference electrodes filled with the manufacturer's recommended reference solution (Orion 90-00-01) were used with all the electrodes except sodium. Orion model 90-02 double junction reference electrode was used with the sodium electrode. Three Orion models 401 and one model 407 specific-ion meters were used with outputs connected to a modified potentiometric strip-chart recorder.

The response of a specific-ion electrode to changes in ionic activity is controlled by the time lag inherent in the electrode. Response lag was determined by adding known amounts of the specific ion to the water used in the study and recording the rate of change of the electrode potential.

For example, sodium chloride was added to the tap water at the same temperature and stirring rate used in the experiment, and the $\mathrm{Na}^{+}$electrode output was recorded on the potentiometric strip-chart recorder. Different activities of $\mathrm{Na}^{+}$were added nearly instantaneously, and no significant difference in response time of the electrode was observed in the range of interest $(250-500 \mathrm{mg} / \mathrm{l})$. This empirical method of testing electrode lag integrates effects of stirring rates and temperature on the response time of the electrodes.

Calcium chloride was used in the same manner to check the response of divalent- and calcium-ion electrodes; the $\mathrm{pH}$ electrode was checked by adding hydrochloric acid; and the flouride electrode was checked by adding sodium fluoride. These electrode response times were also virtually unaffected

\footnotetext{
'The mention of brand names is for a complete description of the methods used and does not constitute an endorsement of the product by the U.S. Geological Survey.
}

by an activity increase in the range of interest of this study. Response time of all electrodes was similar to that observed by Malcolm and Kennedy (1969)-90 percent of full-scale reading was observed in approximately 40 seconds. Orion literature ${ }^{2}$ supplied with the electrodes states that their electrodes respond more rapidly to an increase in activity than to a decrease. In this study, declining activity of sodium nevertheless gave a $\mathrm{Na}^{+}$electrode response that was very rapid (fig. 1).

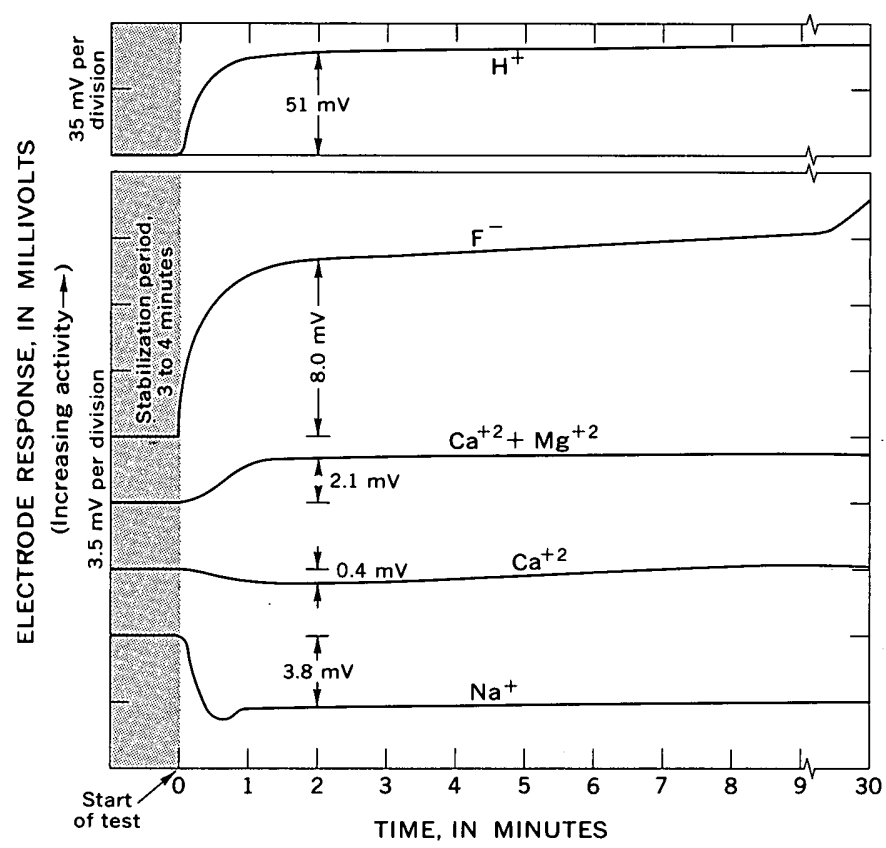

COMPARISON OF ION ACTIVITIES

\begin{tabular}{|c|c|c|}
\hline \multirow{2}{*}{ · } & \multicolumn{2}{|c|}{ Ion activity $(\mathrm{mg} / \mathrm{I})$} \\
\hline & $\begin{array}{c}\text { Initial } \\
(0 \mathrm{~min})\end{array}$ & $\begin{array}{c}\begin{array}{c}\text { Final } \\
(30 \mathrm{~min})\end{array} \\
\end{array}$ \\
\hline $\begin{array}{l}\mathrm{Ca}^{+2} \ldots \ldots \ldots \\
\mathrm{Ca}^{+2}+\mathrm{Mg}^{+2} \\
\mathrm{Na}^{+} \ldots \ldots \cdots \cdots \\
\mathrm{F}^{-} \ldots \ldots \ldots \cdots \\
\mathrm{H}^{+} \ldots \ldots \ldots \ldots\end{array}$ & $\begin{array}{l}7.5 \times 10^{-4} \\
1.2 \times 10^{-3} \\
8.3 \times 10^{-3} \\
5.2 \times 10^{-5} \\
1.41 \times 10^{-8}\end{array}$ & $\begin{array}{l}7.5 \times 10^{-4} \\
1.8 \times 10^{-3} \\
6.7 \times 10^{-3} \\
2.2 \times 10^{-4} \\
1.95 \times 10^{-8}\end{array}$ \\
\hline
\end{tabular}

Figure 1.-Specific-ion electrode traces from $250 \mathrm{ml}$ of Canadian River water and $50 \mathrm{~g}$ of clay-sized material from the Ogallala Formation, Lubbock, Tex.

The divalent electrode was used in this study to follow changes in the activity of magnesium. This was accomplished by simultaneously monitoring changes in calcium activity with the calcium specific-ion electrode. The difference in output between these electrodes represents changes in magnesium activity. Although the divalent electrode responds to the activity of any divalent ion, only the activities of calcium and magnesium were sufficiently large to be significant in this study.

\footnotetext{
${ }^{2}$ Instruction manual, sodium ion electrode, model 94-11, 1969, 17 p. Available from Orion Research, Inc., Cambridge, Mass.
} 
The electrodes were calibrated within the activity ranges that bracketed the expected range of the sample. The electrodes were then suspended in a polyethylene beaker, and 250 $\mathrm{ml}$ of Canadian River water was added and allowed to equilibrate with the electrodes. The recorder was activated and the electrode output was recorded to check for drift.

When the system stabilized, the $50 \mathrm{~g}$ sample was introduced into the water directly on and above a magnetic stirring bar that was rotating at medium speed. The sample was rapidly and thoroughly mixed by the stirring bar. The slurry was monitored until no further potentiometric changes were observed on the recorder. The slurry was then removed, and the electrodes were rinsed in the same type of water used in the experiment and then allowed to reequilibrate in a duplicate water sample. The recorder was reactivated, and the difference between the original and the final reading was considered as electronic drift and applied linearly to the particular electrode trace affected by the drift.

The system was stable, and it was only necessary to make one drift correction on one electrode in the six tests that were conducted. The slurry was filtered under pressure of nitrogen gas immediately after it was removed from the electrodes. Filtering took about 20 minutes. Alkalinity was determined on the first $25 \mathrm{ml}$ of filtrate by use of $0.02 \mathrm{~N} \mathrm{H}_{2} \mathrm{SO}_{4}$ and a pH electrode and meter. The remainder of the filtrate was acidified and saved for conventional chemical analysis.

Before the tests were conducted, the response of the calcium electrode was checked for sensitivity to the $\mathrm{Mg}^{+2}$ ion. ElSwaify and Gazdar (1969) reported that the Orion calcium electrode responded to changes in $\mathrm{Mg}^{+2}$ activities in contradiction to the information supplied by the manufacturer. Virtually the same experiment as conducted by these authors was rerun. The results indicated that the calcium electrode used in this experiment was selective and did not respond to the $\mathrm{Mg}^{+2}$ activity.

\section{EXPERIMENTAL RESULTS}

Because of an interest in five constituents and the availability of only four meters, four similar tests were conducted with different combinations of four electrodes in each test. Figure 1 was drawn from the averages of these four tests, whereas figure 2 was drawn from an average of two tests.

Most of the reactions shown in figure 1 occurred before the electrode could respond; that is, the initial traces of the electrode outputs are determined by the response lag of the electrode. The rapidity of the reactions is a result of ion exchange between the minerals and water, according to the work of Malcolm and Kennedy (1969).

Ion-exchange hypothesis for this rapid reaction is supported by examination of figure 1 , which illustrates a decrease in sodium while a similar but smaller increase in the divalent ions takes place. The response of these two electrodes is not equivalent because of calcium precipitation and solution of minerals in the sample.
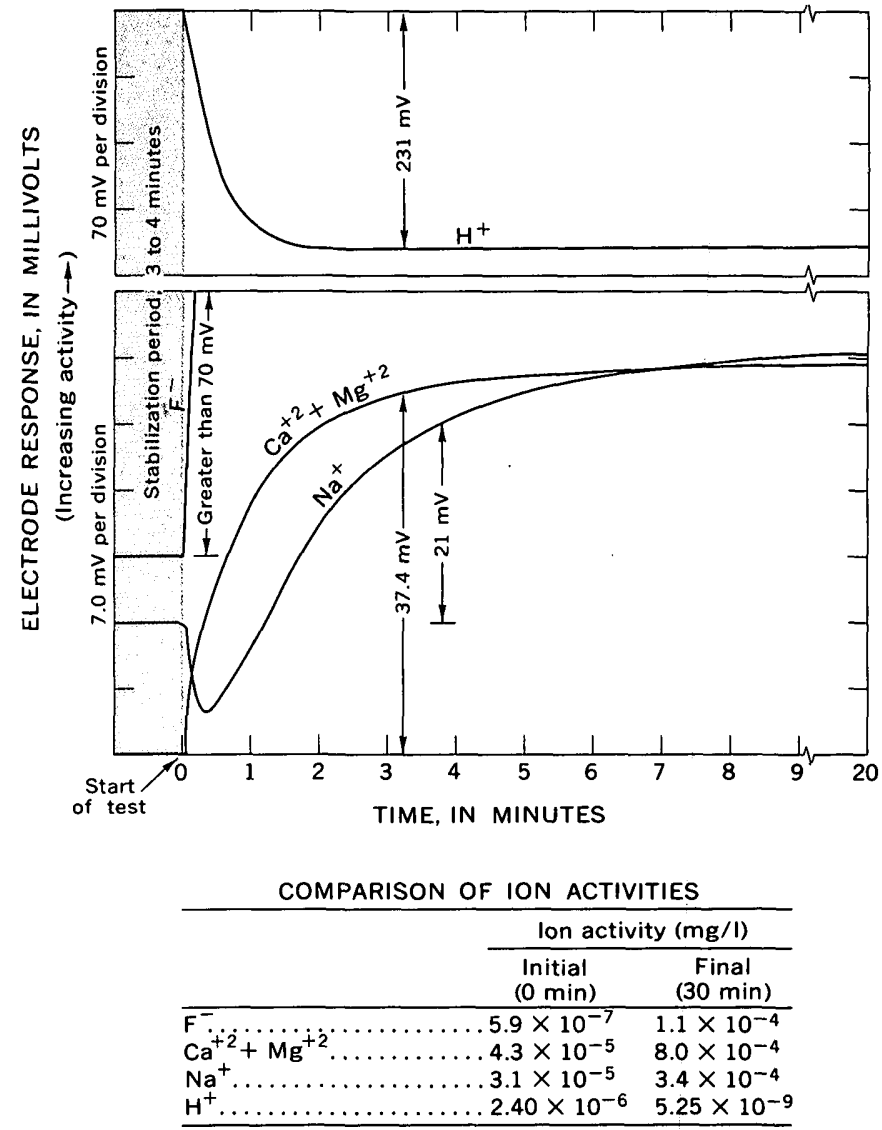

Figure 2.-Specific-ion electrode traces from $250 \mathrm{ml}$ of distilled, deionized water and $50 \mathrm{~g}$ of clay-sized material from the Ogallala Formation, Lubbock, Tex.

Examination of figures 1 and 2 shows that the $\mathrm{Na}^{+}$trace exhibits a small decrease near the start of the experiment. This decrease is unique to the electrode in that it exhibits a brief transient response to changes in hydrogen-ion activity, according to the manufacturer's literature, and is not a function of the solution being examined. The initial response of this particular electrode indicates a lower sodium activity regardless of the increase or decrease in hydrogen-ion activity.

Calcium precipitation is indicated by the lack of potentiometric change of the calcium specific-ion electrode and the loss of $31 . \mathrm{mg} / 1 \mathrm{HCO}_{3}^{-}$from the water. The Canadian River water was in thermodynamic equilibrium with calcite at the time of the test. It is, therefore, not surprising that the combination of stirring and availability of calcium carbonate nucleation sites resulted in precipitation of calcium as it exchanged and dissolved from the sample.

The calcium electrode indicates an initial decline in calcium activity that returns to the original activity within a few minutes. This slight drop probably is the result of the water being initially slightly supersaturated with respect to calcite and therefore seeking equilibrium as more calcium is introduced. The decline may also be in response to some transient inorganic complex, or perhaps it is the electrode-ion exchanger 
equilibrating to a rapidly changing environment. This slight drop, regardless of its origin, is not significant in this study.

Fluoride apparently enters the water by an exchange reaction as well as from mineral solution. By analogy with the divalent and sodium electrodes, the early part of the fluoride curve indicates ion exchange, probably for the hydroxyl $\left(\mathrm{OH}^{-}\right)$ion, while a longer term (30 minutes) increase is interpreted as the solution of some fluoride-rich mineral. However, fluoride dissolved very rapidly from the sample when it was mixed with distilled water. It is possible that the rapid as well as the longer term responses result from mineral solution. X-ray analyses did not indicate detectable quantities of any fluoride mineral. However, volcanic ash in the Ogallala (Sidwell and Bronaugh, 1946) could have furnished small quantities of fluoride-rich minerals which escaped detection.

The hydrogen-ion activity increased very rapidly. This increase in activity is probably a function of the precipitation of calcium carbonate. The $\mathrm{pH}$ remains constant after the first 2 minutes of the test and does not appear to respond to the adjustment of the calcium ion.

To examine the rate of solubility of the clay-sized material, distilled water was used in place of Canadian River water for the test shown in figure 2. This substitution assured that the dominant chemical control would be solution and not ion exchange in this environment, although ion exchange would undoubtedly occur as ions were made available through solution.

The general shape of electrode traces in figure 2 is one of a gradual attainment of a steady-state condition and does not appear to be that of electrode response as was exhibited in figure 1 . The difference is more apparent when it is recognized that the millivolt scale in figure 2 is double that of figure 1.

Figure 2 illustrates the speed of the fluoride reaction; the trace of this electrode goes off scale in less than 1 minute. This rapid reaction appears to indicate an ion-exchange reaction or the presence of an extremely soluble mineral. In the initial acidic environment in which this test was run, it is improbable that there should be ion exchange of $\mathrm{OH}^{-}$, although there may be some small amount of exchange with $\mathrm{SO}_{4}^{-2}$ or $\mathrm{Cl}^{-}$if some of the $\mathrm{F}^{-}$is held on nonspecific positive sites. Therefore, it would appear that there is a very soluble fluoride mineral present. Because of the large range in millivolt output and the manner in which signals were recorded, it was not possible to follow the fluoride through to a steady-state condition while monitoring the other electrodes.

The calcium electrode was not used in the test with distilled water because of the lack of sample on which to run more than two tests. However, the analyses indicate that there were soluble calcium minerals present and that the divalent electrode response was from both calcium and magnesium. The $\mathrm{pH}$ changed rapidly and attained a steady state in approximately 2 minutes. Sodium required nearly 9 minutes, while the divalent electrode required about 4 minutes to attain a steady-state condition.
The electrodes in distilled water are near their limit of detection, which is approximately $10^{-6}$ mole for fluoride, $10^{-6}$ mole for sodium, and $10^{-8}$ mole for the divalent electrode. Consequently, the large change in potential exhibited by the electrodes in figure 2 represents significant changes in activity; however, because the electrodes are logarithmic devices, the absolute values of the changes in concentration are relatively small (table 1 ). The presence of 15 $\mathrm{mg} / \mathrm{l} \mathrm{SO}{ }_{4}^{-2}$ and $40 \mathrm{mg} / \mathrm{l} \mathrm{Cl}^{-}$in the water and the $62 \mathrm{mg} / \mathrm{l}$ noncarbonate hardness as $\mathrm{CaCO}_{3}$ indicate that sulfate and chloride minerals, not detected by X-ray analyses, furnish part of the calcium and magnesium to the water.

The filtered effluent from the distilled water test is not in thermodynamic equilibrium with common minerals. The effluent is undersaturated with respect to calcite, aragonite, anhydrite, gypsum, dolomite, and magnesite. Undersaturation with respect to these calcium minerals is not surprising because of the limited amount of material present for solution and the total contact time of less than 1 hour.

In the natural geologic environment, mineral solution and ion exchange would not continue indefinitely. Reaction rims of altered material would probably form around mineral grains, and the rate of reaction would then be controlled by slow diffusion through the rims (Malcolm and Kennedy, 1970; Helgeson, 1971). Ion exchange, though initially rapid, would eventually cease to operate as exchange sites are occupied and an equilibrium condition is formed. Thus, when water is initially introduced into a natural environment it will approach equilibrium with that environment in a short period of time.

During artificial recharge, water moves through the natural environment forming an advancing front. Water near the point of recharge will quickly approach equilibrium. Mineral solution and ion exchange will take place rapidly only as long as there is fresh material available. As this fresh material is exhausted, a chemical reaction front will advance in the direction of hydraulic flow.

\section{CONCLUSIONS}

Experiments with distilled and Canadian River water indicate that ion exchange and solution of certain common minerals are relatively rapid. The speed of solution of sulfate, chloride, fluoride, and carbonate minerals in the sample permit the assumption of instantaneous mineral solution for the purposes of modeling the coupled chemical and hydrologic environment. It is anticipated that reactions such as these will take place at an advancing front of recharged water. The problem associated with mineral precipitation is not so readily solved. In the experiment, the stirring and availability of nucleation sites most certainly prevents supersaturation of the water with respect to many of the mineral phases, but the problem of predicting the rate of mineral precipitation in the natural environment is as yet unanswered. 


\section{REFERENCES CITED}

El-Swaify, S. A., and Gazdar, M. N., 1969, Evaluating the use of $\mathrm{Na}^{+}$, $\mathrm{Ca}^{++}$, and divalent cation electrodes in some soil extracting solutions: Soil Sci. Soc. America Proc., v. 33, p. 665-667.

Helgeson, H. C., 1971, Kinetics of mass transfer among silicates and aqueous solutions: Geochim. et Cosmochim. Acta, v. 35, no. 5, p. 421- 469 .
Malcolm, R. L., and Kennedy, V. C., 1969, Rate of cation exchange on clay minerals as determined by specific-ion electrode techniques: Soil Sci. Soc. America Proc., v. 33, no. 2, p. 247-253.

1970, Variation of cation exchange capacity and rate with particle size in stream sediment: Jour. Water Pollution Control Federation, v. 42, no. 5, pt. 2, p. R153-R160.

Sidwell, R. L., and Bronaugh, R. L., 1946, Volcanic sediments in northern Texas: Jour. Sed. Petrology, v. 16, p. 15-18. 


\title{
HYDRAULIC SAND-MODEL STUDIES OF MISCIBLE-FLUID FLOW
}

\author{
By J. M. CAHILL, Lakewood, Colo.
}

\begin{abstract}
Hydraulic sand models are useful physical tools in the investigation of the transition zone that occurs between salt and fresh ground water in coastal aquifers. Such models are used to demonstrate the effects of transport mechanisms that influence the dynamic behavior and the shape of the transition zone. The techniques employed in obtaining in-place measurements of solute concentrations are generally the stumbling block in generating data for twodimensional dispersion systems. Two in-place measurement techniques were used in the studies described: (1) conductivity probes when salt was used as a tracer; and (2) photoelectric cells when organic dye was used as a tracer. Results indicate that conductivity methods are more reliable; however, care must be exercised inasmuch as the probes tend to disturb the fluid flow.
\end{abstract}

In investigations of fluid-flow behavior, mathematical and physical models may be used. Limitations in using such models result from the complexity of the mathematical language or the inability to properly construct an accurate physical counterpart. The mathematical model is used when the governing equations are known, and the solution of these equations can be used for data analysis. Physical models, such as electrical analogs and hydraulic models, are most useful for studying systems having complex boundary conditions. However, scaling requirements for the model impose some restrictions on model construction as do available methods for measuring response in the model. Further, obtaining reliable data from physical models is related to the experience of the individual experimenter.

The theory of models is based on the concept of similarity of the three fundamental dimensions-length, time, and mass. In detailing the transport process in hydraulic sand models, the internal geometry of the medium presents some difficulty if strict adherence to this similitude is maintained. This is especially true when ordinary fluids such as clear water or water-based fluids are used. This difficulty occurs because grain diameter is a characteristic geometric length. Maintaining the scaling of grain diameters would require the reduction of the pore size, which also influences the dispersion process. Thus, scaling the grain size in a small laboratory model will reduce the pore size in the model to molecular dimensions, and physical activity in the model would be similar to the process of diffusion through solid material.

The models used in these studies were not for the punose of detailing the transport process for any particular grouna-water system. Rather, the primary purpose of the models was to view dispersion of two miscible fluids. Miscible-fluid systems are those in which fluids mix in any ratio without separation. Because the transport process is controlled largely by pore geometry and fluid velocity, it can be assumed that fluid behavior in the models will have a similar response in nature under the same boundary conditions.

Problems in modeling the dynamics of miscible-fluid flow involve controls established by both external and internal geometry. Systems such as salt-water encroachment are difficult to describe mathematically because of the dynamic boundary between fluids of different densities. These systems can be physically modeled with less effort, and various methods have been discussed in the literature for many years. For example, Bear and Todd (1960) extended the study of salt-water encroachment to include both miscible and immiscible systems. Mathematical models give the approximate shape of the fresh water-salt water interface. The derived expression as indicated by Henry (1964, p. C35-C59, in Cooper and others) gives a good approximation for the position of the interface at some distance from the ocean. Cooper and others (1964), using an area in Florida, also described the diffused zone in terms of a "cyclic-flow" phenomenon. Cyclic flow takes place as the salt water flows inland from the sea floor into the zone of diffusion and back to the sea through an upper flow region. The body of water flowing towards the sea is within the upper flow region.

Although small sand models are valuable tools for studying the dynamics of miscible-fluid flow, they also have limitations. One of the primary difficulties in modeling this type of system is the lack of a reliable means of measuring the mixing ratios of the miscible fluids with minimum disturbance to the flow regime. This report describes the construction and operation of one- and two-dimensional sand models and techniques used to measure the tracer concentrations. In addition, some preliminary data are presented.

\section{METHODS OF STUDY}

Hydraulic sand models were used to study the dynamics and transport process of a coastal aquifer in two dimensions. Orientation of the models was perpendicular to the coastline or parallel to the direction of fluid flow. A photograph of a 
typical hydraulic model is shown on figure 1. The models were designed so that both visual observations and internal measurements of tracer concentrations could be made. Loose sand or glass beads, the principal aquifer material, were encased in transparent acrylic plastic. The clear-plastic wall facilitated measurement because it allowed visual detection of the tracer fluid.

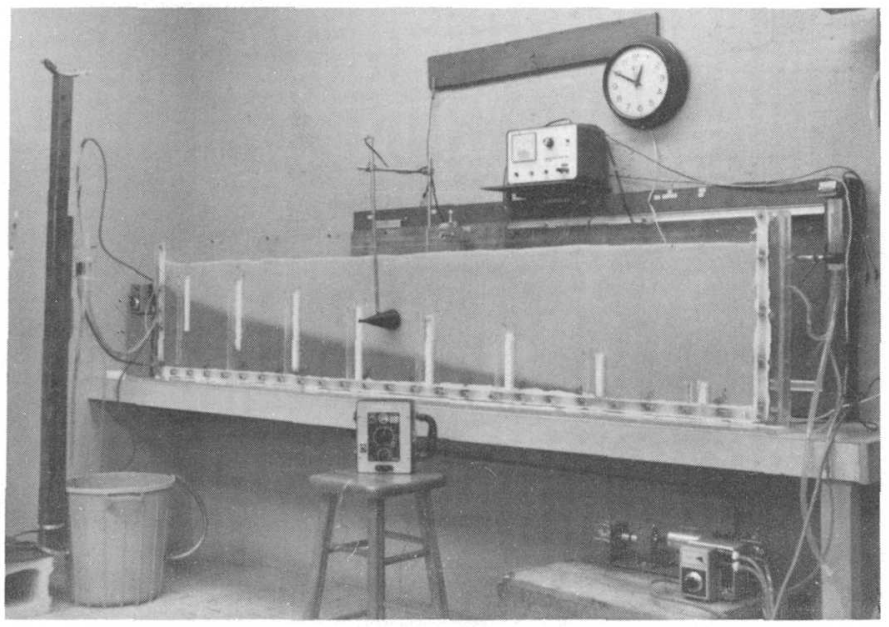

Figure 1.-Hydraulic sand model used in salt-water encroachment studies. Fluid movement is "landward" to the right and "seaward" to the left.

\section{Model fluids}

Tap water ( $\mathrm{sp} \mathrm{gr}=1.000)$ was used as the original fluid or the less dense fluid in the models. The second or heavier fluid $(\mathrm{sp}$ gr $=1.025)$ was a mixture of one part commercial grade glycerine and nine parts of tap water. Organic dye and sodium chloride were added to the heavier fluid as tracer indicators. The organic dyes were different commercial brands of recorder inks.

Rumer and Harleman (1963), in addition to other investigators, have used sugar to make up the heavier fluid. Glycerine was the preferred additive in this study because of ease and accuracy in duplicating mixtures when additional amounts were needed. In addition, the glycerine remained in solution with the tap water for many months. Data obtained in this study indicated that glycerine and sodium chloride solutions traveled at almost the same rate. In tests involving pore velocities of 0.2 to $2.0 \mathrm{~cm} / \mathrm{min}$, the differences in the distribution of the concentrations of glycerine and salt were less than the precision with which their concentrations could be measured. The determinations of concentration were made with an electrical-conductivity probe for chloride and a hand refractometer for glycerine.

The results shown on figure 2 are for a flow rate of 0.3 $\mathrm{cm} / \mathrm{min}$. These curves are the breakthrough concentrations of the heavy fluid composed of glycerine and sodium chloride. The results show good correlation between salt and glycerine.

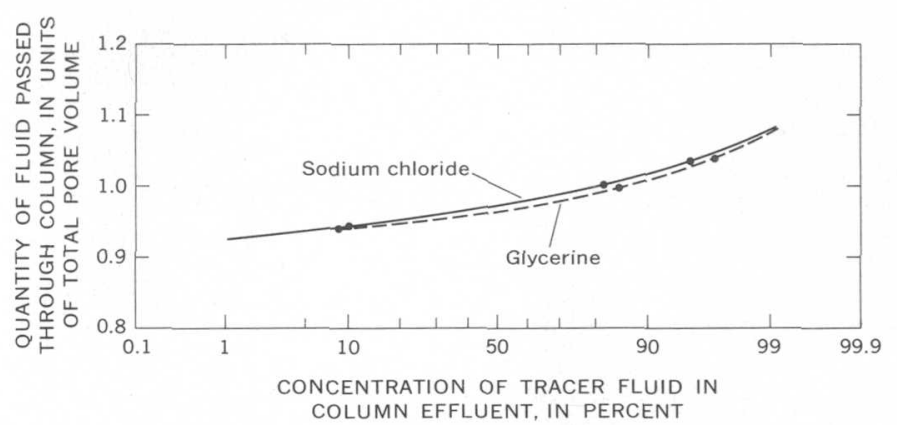

Figure 2.-Changes in concentration of tracer in effluent from column of spherical beads with passage of tagged fluids through column.

\section{Tracer-concentration measurement}

Bear (1961), in his investigation of fluid dispersion, described a method of measurement involving transmission of light through a Christiansen model. Cahill (1966) also showed that this method of measurement was effective with the use of organic dye tracers. The concentration profile of the dye tracer in the models is determined by correlating the measured light intensity with that of known dye-tracer concentrations. The system, as shown in figure $3 A$, is not a Christiansen model in that the index of refraction of the glass beads was not matched against that of the fluid. However, the system of measurement was similar to Bear's in that a cadmium sulfide photocell was used as the measuring device. The measurement apparatus included a light source and photocell mounted on a parallel arm extending downward from the top of the model on a continuous screw. This arrangement allowed positioning the source and the cell simultaneously. The cadmium sulfide cell was located in a tapered housing with a slit opening to obtain near-point measurement (figure $3 B$ ).

The cadmium sulfide cell was well suited for measuring the intensity of illumination in this test apparatus because of its size and operating characteristics. The available range allowed use of standard supporting instrumentation. Photocells of the type used are known as photoresistors or light-dependent resistors (Radio Corp. of America, 1964), and their resistance to the flow of electricity depends on the intensity of light impinging on the cell. The response of the cell, which is proportional to the illumination, can be measured with an ohmmeter. In these experiments, the light beam from the constant-intensity source is randomly scattered and adsorbed by the dye molecules and the matrix material. Where the porous material is chemically stable, the measured resistance is dependent only on the dye concentration.

Various studies, such as by Kaufman and Orlob (1956), show that chloride ions in low concentrations are the simplest tracers to use. Chloride is readily available, economical, and easy to detect. Chloride, in a salt solution, is electrolytic and can be detected by measuring the electrical conductivity of the fluid between two electrodes. With an increase in concentra- 
$A$

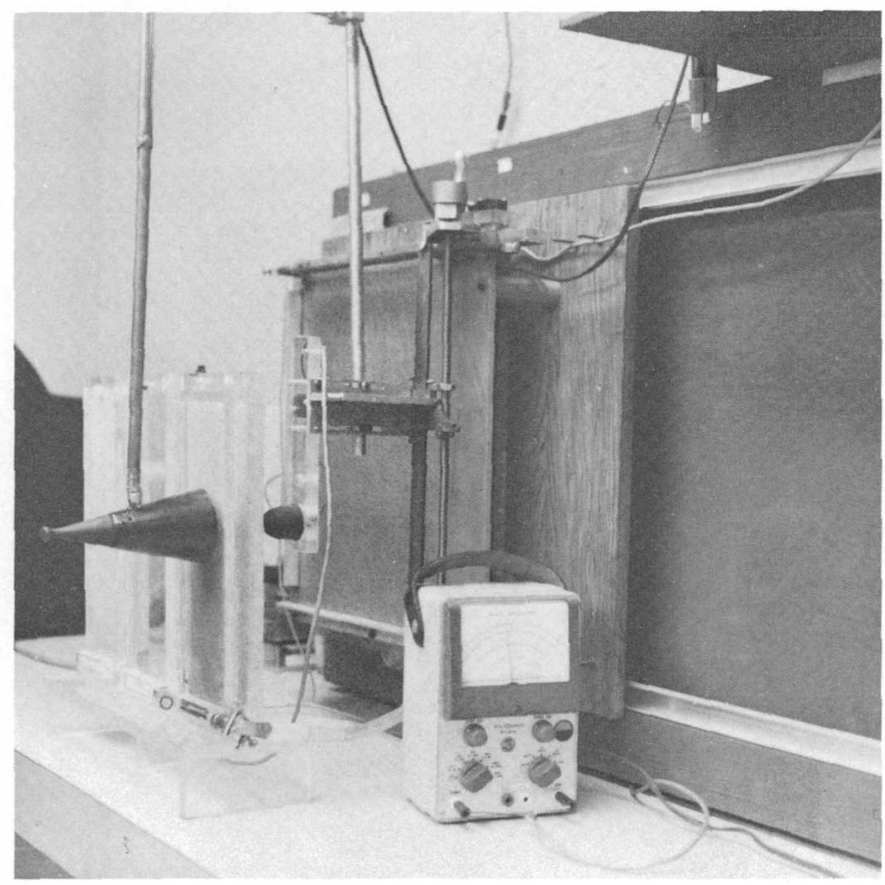

$B$

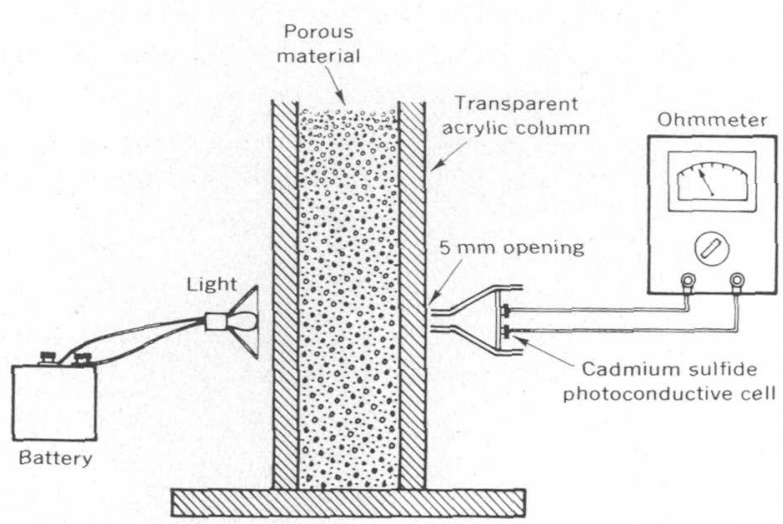

Figure 3.-Apparatus used to detect movement and to measure the concentration of dye tracers in the model.

A. Photograph shows the light source at the left and the photocell at the right of the column. The ohmmeter measures the photocell's response to the light transmitted throughout the length of the column. It is raised and lowered by lead screw and hand crank.

$B$. Schematic diagram shows the components of the model.

was used. The flexibility of the needles was the only difficulty encountered, and at times they required more than one insertion into the model.

\section{HYDRAULIC SAND MODELS}

Generally, rating curves are developed for each probe in the model. This procedure is necessary because nonuniform packing of the material and slight physical differences in each probe will contribute to differences in probe response. Rating curves are obtained by introducing fluids of known concentrations into the column and correlating the tracer concentrations with the meter readings. In the column studies, it was observed that changes in conditions near the probes or in the characteristic of the probes were sufficient to give errant readings with time. Therefore, tracer concentration plotted against percentage of meter deflection was used to obtain consistent results with a representative single-calibration curve.

The construction of the conductivity probes affects the dispersion process because insertion of the probes disturbs the fluid. Initially, probes made of 1-mm-diameter platinum wire were embedded in the plastic wall of the model, but later these were replaced by probes made of stainless-steel 26-gage $(0.48-\mathrm{mm})$ hypodermic needles. The needles were inserted through small holes filled with silicone-rubber sealer. The sealer did not leak when punctured by the needle or when the needle was pulled out.

The fixed-probe system was used initially in both the vertical column and two-dimensional model. It was found that disturbance created by the fixed probes was not severe for low flow rates, but these probes exhibited changes in characteristics and frequent recalibration was needed. The hypodermic needle probes proved reliable when the single-calibration curve

\section{Column model}

A vertical-hydraulic or column model (fig. 4) was used for analysis of the dispersive characteristics of both steady and unsteady flow in one dimension. The column was investigated first to provide information for the two-dimensional flow model. In the two-dimensional system, fresh water flows over the heavier salt water (fig. 1); therefore, prior determination of dispersion in one direction is necessary to define the transport process.

In constructing the sand model, glass beads were slowly poured into the container filled with tap water. This minimized entrapment of air in the voids. During and after pouring, the sides of the containers were tapped lightly to obtain compaction. Because this procedure separates the particles, variations in fall velocity caused some layering. However, because the glass beads were nearly uniform, layering should not have affected the results.

The glass beads, which were spherical and translucent, had an average diameter of $0.58 \mathrm{~mm}$. Porosity was calculated from data on the weight of beads in a given volume of container. Although variations in porosity were small, variations in permeabilities were large, ranging from 30 to $40 \mathrm{~cm} / \mathrm{min}$. These values of permeabilities and porosity were determined prior to and, on some occasions, after the test runs were completed. 

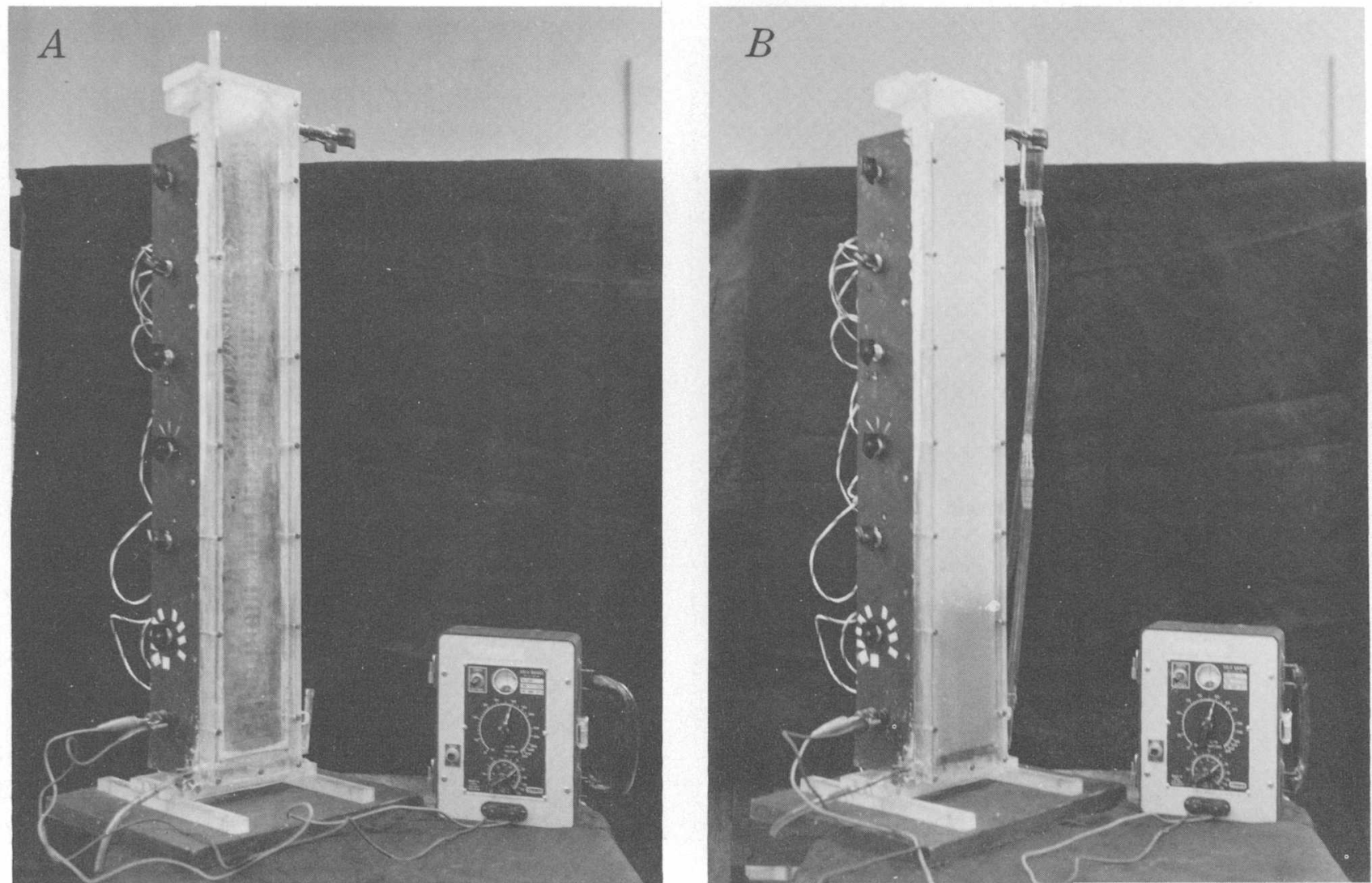

Figure 4.-Vertical column used to measure the one-dimensional dispersion characteristics of the porous medium. A. Column without porous medium. The buttonlike probe electrodes are faintly visible in the column. The rotary switches at the left choose the appropriate set of probes, and response is measured with the conductivity meter.

$B$. Movement of invading fluid (dark) is from the bottom upward.

Salt concentration in the one-dimension column model was measured by paired electrodes. The initial test model had 61 pairs of probes spaced $1 \mathrm{~cm}$ apart in the direction of flow. The readings of each pair were obtained by manual selection using a series of rotary switches attached to the vertical column (figure $4 A$ ).

Flow to the models was controlled by a constant-rate piston pump, which fed a reservoir or constant-head tank which in turn fed directly into the models. Although this method introduced a pulsing at the reservoir tank because of the characteristics of the piston pumps, this effect was relatively minor when flow rate was averaged over time. Smaller pulses were noted when peristaltic pumps, such as "sigmoid worm" pumps, were used. However, tubing fatigue caused a change in the input rate after 2 or 3 days of operation.

\section{Two-dimensional model}

The two-dimensional model (fig. 1) required that the heavier fluid be introduced at a lower level. The salt-water input rate was controlled by a constant-head tank in response to the amount of salt flowing out of the system. To induce unsteady flow that simulated tidal fluctuations in both the one- and two-dimensional models, the salt-water input tank was oscillated vertically by a pulley system shown at the left on figure 1 .

For the two-dimensional model, the control needed to maintain a given front or contact region of salt and fresh water at the desired location was the determining factor in sizing of the model. Models less than $200 \mathrm{~cm}$ long were unsatisfactory because a small change in head caused salt water to enter the fresh-water source area. The dimensions of the model shown in figure 1 were $240 \mathrm{~cm}$ long, $30 \mathrm{~cm}$ high, and $2 \mathrm{~cm}$ thick (inside dimensions). These dimensions were chosen because it was possible to establish at least three steady positions of the salt water-fresh water contact in the model without too much difficulty.

The discharge of the model was collected in a separate compartment to prevent the progressive change in density of the salt water input. The tagged-fluid effluent was removed from the model at the upper left as shown in figure 1. This enabled monitoring of the discharge by means of an electrical probe. All measurements of the position and the concentration along the contact zone were taken after steady-state condition was realized or at midtide in the models when the salt-water level was oscillated. 


\section{DISCUSSION OF RESULTS}

The one-dimensional model was used to generate data under two different boundary conditions-constant and sinusoidal input. In all test runs, the model initially contained clear tap water. After stable conditions were reached, the test fluid was introduced into the column. The flow in the column was upward to minimize fingering which is generally caused by a gravitational effect. In the test series, the sinusoidal inputboundary condition was imposed by oscillating the head tank about the mean elevation. Maintaining a frequency of one cycle every 20 minutes, three different amplitudes of oscillation, 1,2 , and $4 \mathrm{~cm}$ were used to determine the effects of the nonsteady fluid motion on the dispersion of tagged particles. The average pore velocities of various tests ranged from 0.02 to $2 \mathrm{~cm} / \mathrm{min}$. The concentrations of tracer material at selected points in the column were determined with the electrical probes.

Computation of the preliminary values of longitudinal dispersion coefficients for unsteady flow in the onedimensional model was based on the expression described by Harleman and Rumer (1963, p. 388):

$$
C / C_{\mathrm{o}}=1 / 2 \operatorname{erfc}\left[\frac{x-u t}{\sqrt{4 D t}}\right]=\left[1 / 2\left(1-\operatorname{erf} \frac{x-u t}{\sqrt{2 D t}}\right)\right]
$$

where

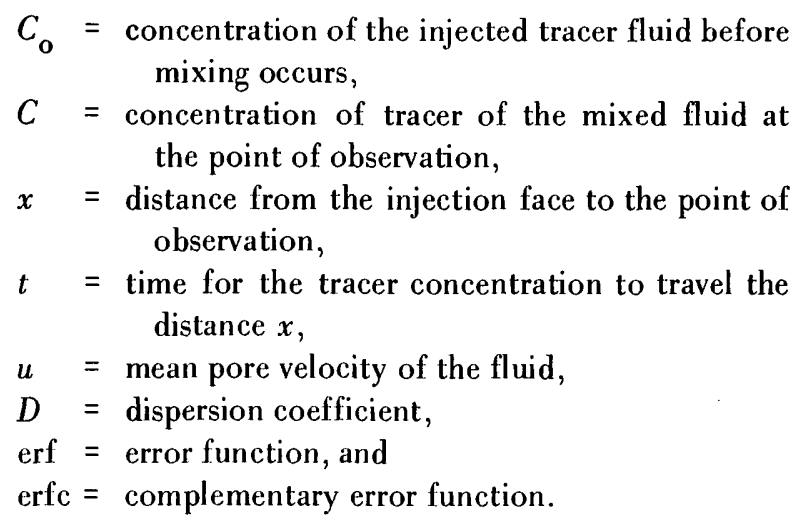

Values of the erfc can be found in Abramowitz and Stegum (1964, p. 310-315).

An easy means of solving for $D$ is by the analytical method. Thus, to compute $D$ we define $\xi=u t / x$ and $\zeta=D / u x$. Equation 1 is now expressed as:

$$
C / C_{\mathrm{o}}=1 / 2 \operatorname{erfc}\left[\frac{1-\xi}{2 \sqrt{\xi \zeta}}\right]=1 / 2 \operatorname{erfc} \Phi
$$

In this expression, $D$ is the only unknown. Because $C / C_{\mathrm{o}}$ is known, $\Phi$ can be determined from tables of error functions. $D$ can be eliminated temporarily from the equation by expressing $\xi$ as a function $\Phi$, thus $\Phi(\xi)=\frac{1-\xi}{2 \sqrt{\xi}}$. Because $u, t$, and $x$ are known, $\Phi(\xi)$ can be computed for corresponding values of $C / C_{0}$; that is, values of $\Phi$ can be obtained and related to values of $\Phi(\xi)$ for specific $C / C_{\mathrm{o}}$ values.

The values of $\Phi$ and corresponding values of $\Phi(\xi)$ are plotted graphically on coordinate paper. The values of $\Phi$ are plotted on the abscissa and values of $\Phi(\xi)$ on the ordinate in the Cartesian coordinate system. A best-fit straight line is drawn through the experimentally determined values, and the slope of this line is determined. The dispersion coefficient $D$ can now be computed by reasoning that

$$
\text { slope }=\frac{\Phi(\xi)}{\Phi}=\sqrt{\zeta}=\sqrt{\frac{D}{u x}} .
$$

The computed values of dispersion in square centimeters per minute for two boundary conditions are given in table 1 . These boundary conditions account for oscillatory and nonoscillatory effects on the fluid body as it moved through the column.

Preliminary comparison of the effects of two boundary conditions (nonoscillatory and oscillatory) showed that there was only a slight difference in the width of the frontal diffused zone for both conditions. In other words, concentration distribution determined at each station remained about the same in the steady and unsteady systems. Computations as shown in table 1 indicate that for low flow, the calculated dispersion coefficient varied by a factor of 3 with changing tidal amplitude. With the higher flow rates, the values became erratic.

These results indicate that the fixed probes influence the flow pattern and, therefore, the dispersion mechanism. The geometry of the probes attached to the wall of the vertical column may have been such that only the fluid channeled near the wall was measured. Because the dispersion coefficient is a function of fluid velocity, some changes in dispersion were detected with an increase in fluid velocity. However, failure to detect additional changes in the dispersion coefficient with tidal-amplitude changes indicates that the fixed probes were most likely the cause. Further testing will be required before the cause can be definitely established.

It should be noted that these column tests, although repetitious, were carried out for two reasons. The first was to establish the effectiveness of using chlorides or color as a standard measuring technique. The second was to establish the dispersion coefficient in one dimension for extension into the two-dimensional horizontal model. Initially, verification of published data was desired to establish the reliability of the testing procedure. When measurement of light transmission was used, it was noted that the organic dye tracer tended to fade with time (fig. 5).

Correcting for the fading was impractical because the dye completely faded with time at the low flow rates. It was found that the dye lagged as much as $2 \mathrm{~cm}$ behind the chloride when the fluid traveled $16 \mathrm{~cm}$ in 13 hours. Thus it was apparent that only for fast fluid velocities could the dye be used as a reliable 
Table 1.-Preliminary calculations of the longitudinal dispersion coefficient for nonoscillatory and oscillatory flow in a rectangular vertical sand column

\begin{tabular}{|c|c|c|c|c|c|c|c|}
\hline \multirow{3}{*}{$\begin{array}{l}\text { Test } \\
\text { No. }\end{array}$} & \multirow{3}{*}{$\begin{array}{c}\text { Fluid pore } \\
\text { velocity } \\
(\mathrm{cm} / \mathrm{min})\end{array}$} & \multirow{3}{*}{$\begin{array}{l}\text { Oscillation } \\
\text { amplitude } \\
(\mathrm{cm})\end{array}$} & \multicolumn{5}{|c|}{ Computed dispersion $\left(\mathrm{cm}^{2} / \mathrm{min}\right)$} \\
\hline & & & \multicolumn{5}{|c|}{$\begin{array}{l}\text { Travel distance of tracer fluid from injection } \\
\text { face to station }(\mathrm{cm})\end{array}$} \\
\hline & & & 17 & 18 & 19 & 20 & 21 \\
\hline $1 \ldots \ldots \ldots$ & $\begin{array}{r}0.021 \\
.023 \\
.022 \\
.022 \\
\end{array}$ & $\begin{array}{l}0 \\
1 \\
2 \\
4\end{array}$ & $\begin{array}{r}0.0013 \\
.0012 \\
.0014 \\
.0018 \\
\end{array}$ & $\begin{array}{l}0.0010 \\
.0011 \\
.0016 \\
.0023 \\
\end{array}$ & $\begin{array}{r}0.0010 \\
.0011 \\
.0023 \\
.0028 \\
\end{array}$ & $\begin{array}{r}0.0010 \\
.0020 \\
.0028\end{array}$ & $\begin{array}{r}0.0008 \\
.0021 \\
.0018\end{array}$ \\
\hline \multirow[b]{2}{*}{$2 \ldots \ldots \ldots$} & & & 10 & 19 & 20 & 31 & 32 \\
\hline & $\begin{array}{r}0.105 \\
.105 \\
.106 \\
.108\end{array}$ & $\begin{array}{l}0 \\
1 \\
2 \\
4\end{array}$ & $\begin{array}{r}0.0019 \\
.0034 \\
.0049 \\
.0056\end{array}$ & $\begin{array}{r}0.0021 \\
.0035 \\
.0034 \\
.0039\end{array}$ & $\begin{array}{r}0.0020 \\
.0030 \\
.0035 \\
.0038\end{array}$ & $\begin{array}{r}0.0019 \\
.0032 \\
.0042 \\
.0037\end{array}$ & $\begin{array}{r}0.0017 \\
.0038 \\
.0021 \\
.0037\end{array}$ \\
\hline \multirow[b]{2}{*}{$3 \ldots \ldots \ldots$} & & & 10 & 11 & 12 & 13 & 14 \\
\hline & $\begin{array}{r}0.208 \\
.190 \\
.202 \\
.190 \\
\end{array}$ & $\begin{array}{l}0 \\
1 \\
2 \\
4 \\
\end{array}$ & $\begin{array}{r}0.0140 \\
.0052 \\
.0110 \\
.0068 \\
\end{array}$ & $\begin{array}{r}0.0140 \\
.0065 \\
.0096 \\
.0070 \\
\end{array}$ & $\begin{array}{r}0.0140 \\
.0065 \\
.0110 \\
.0050 \\
\end{array}$ & $\begin{array}{r}0.0150 \\
.0089 \\
.0070 \\
.0073 \\
\end{array}$ & $\begin{array}{r}0.0110 \\
.0080 \\
.0060 \\
.0051 \\
\end{array}$ \\
\hline \multirow[b]{2}{*}{$4 \ldots \ldots \ldots$} & & & 18 & 27 & 35 & & \\
\hline & $\begin{array}{r}0.42 \\
.43 \\
.42 \\
.43\end{array}$ & $\begin{array}{l}0 \\
1 \\
2 \\
4\end{array}$ & $\begin{array}{r}0.023 \\
.018 \\
.021 \\
.022\end{array}$ & $\begin{array}{r}0.014 \\
.015 \\
.014 \\
.021\end{array}$ & $\begin{array}{r}0.013 \\
.015 \\
.016 \\
.032\end{array}$ & & \\
\hline & & & 17 & 27 & 37 & & \\
\hline $5 \ldots \ldots \ldots$ & $\begin{array}{r}1.17 \\
.86 \\
.86 \\
.90\end{array}$ & $\begin{array}{l}0 \\
1 \\
2 \\
4\end{array}$ & $\begin{array}{r}0.083 \\
.057 \\
.058 \\
.044\end{array}$ & $\begin{array}{r}0.079 \\
.028 \\
.040 \\
.039\end{array}$ & $\begin{array}{r}0.048 \\
.083 \\
.039 \\
.062\end{array}$ & & \\
\hline
\end{tabular}

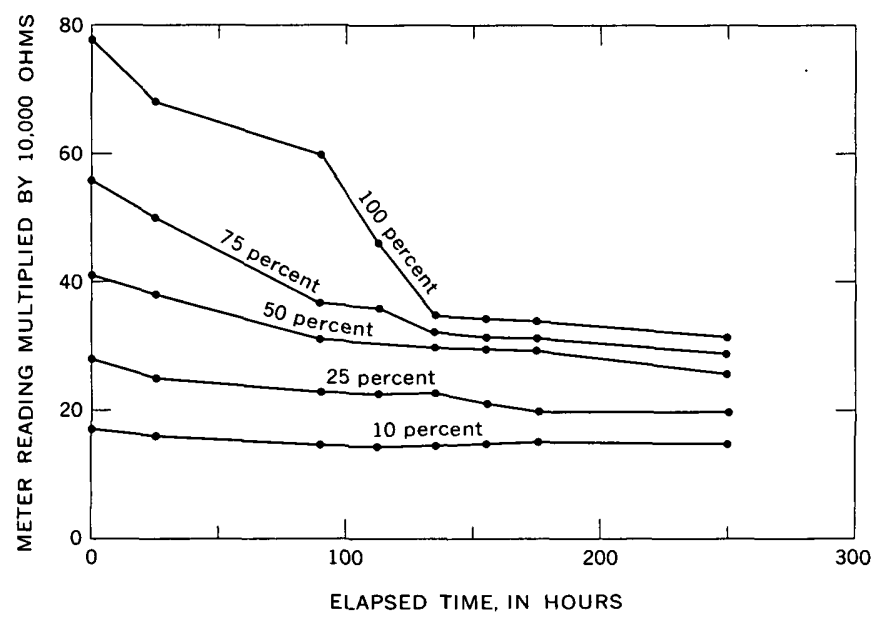

Figure 5.-Changes in resistance registered by the photoelectric cell as color concentration of dye tracer fades with time.

indicator of the concentration profile in studying the transport mechanism in porous material. Because of its simplicity and the ability to measure the required property outside of the region of flow, this method of measurement is desirable if a reliable dye tracer is available.

The two-dimensional models were used initially without oscillating the salt-water body to verify published data. For each experiment, a quantity of fresh-water input or average flow was established, and the denser fluid containing the tracer substance was allowed to reach equilibrium with this freshwater flow. When dynamic equilibrium was attained, the position of the wedge was recorded by measuring the concentration profile of the mixed zone with either fixed or removable conductivity probes. For unsteady flow systems, the salt-water head tank was oscillated while a given amount of fresh water flowed through the model. After some experience it was possible to determine the number of oscillations required before the concentration profile in the mixed zone was stable. Various tests were conducted for different fresh-water flow rates and amplitudes in tidal fluctuations.

A typical concentration profile of the dispersed zone as mapped by traversing vertically at each station is shown on figure 6. Entrances to use the removable electrical probe to measure the chloride-tracer concentration in the mixed zone were spaced at vertical intervals of $1 \mathrm{~cm}$. These concentration profiles, which are not normal to the interface, need to be corrected before analysis. Because a narrow dispersed zone was obtained in the model and because entrances for concentration detection were spaced $1 \mathrm{~cm}$ apart, only seven points were established for any one station (fig. 6). The curve does represent a characteristic dispersion-concentration profile, but is wider than expected because measurements were not taken normal to the interface.

A typical distribution of salt water at the interface of the 


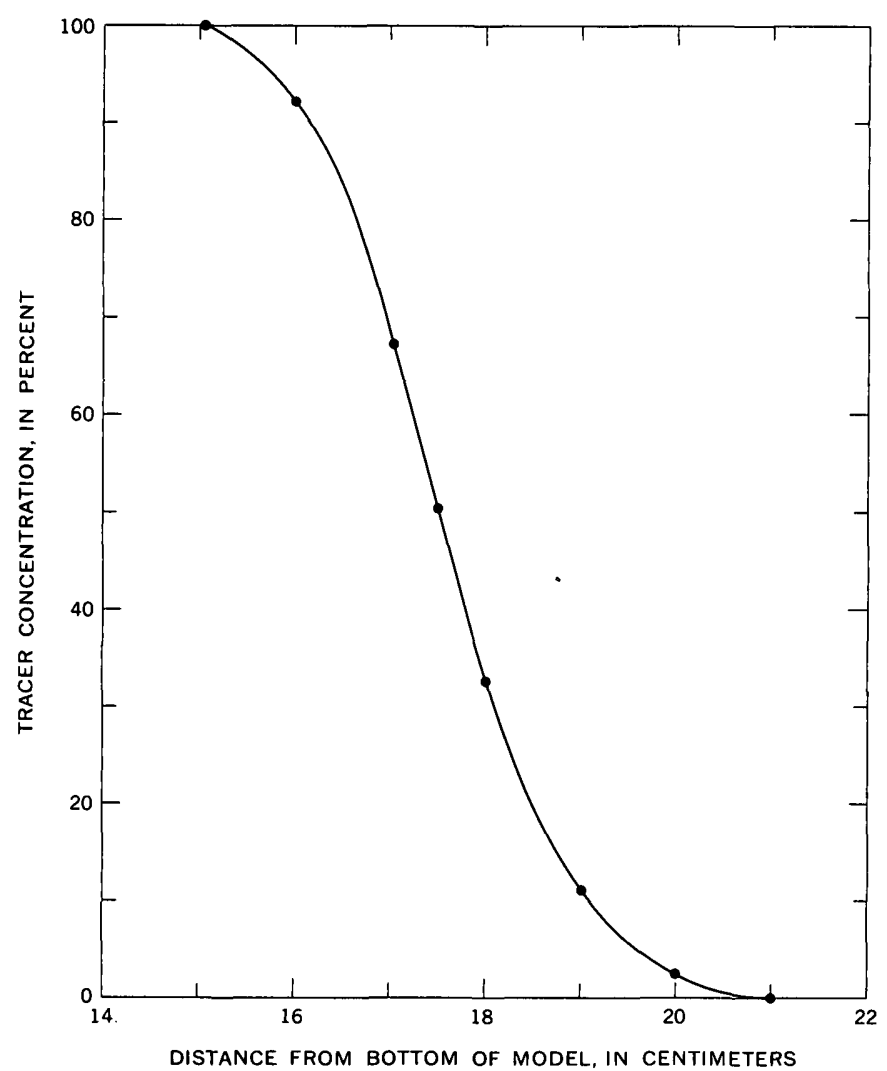

Figure 6.-Typical tracer-concentration profile in the "zone of diffusion" of a two-dimensional hydraulic sand model.

fluids is shown on figure 7 . For this test, the quantity of fresh-water flow in the model was $4.5 \mathrm{ml} / \mathrm{min}$. Each station was measured to determine the line of equal concentration. The concentrations of 10,50 , and 90 percent, shown by solid lines, were determined for the steady-flow system. The effluent for this condition contained 12 percent salt water.

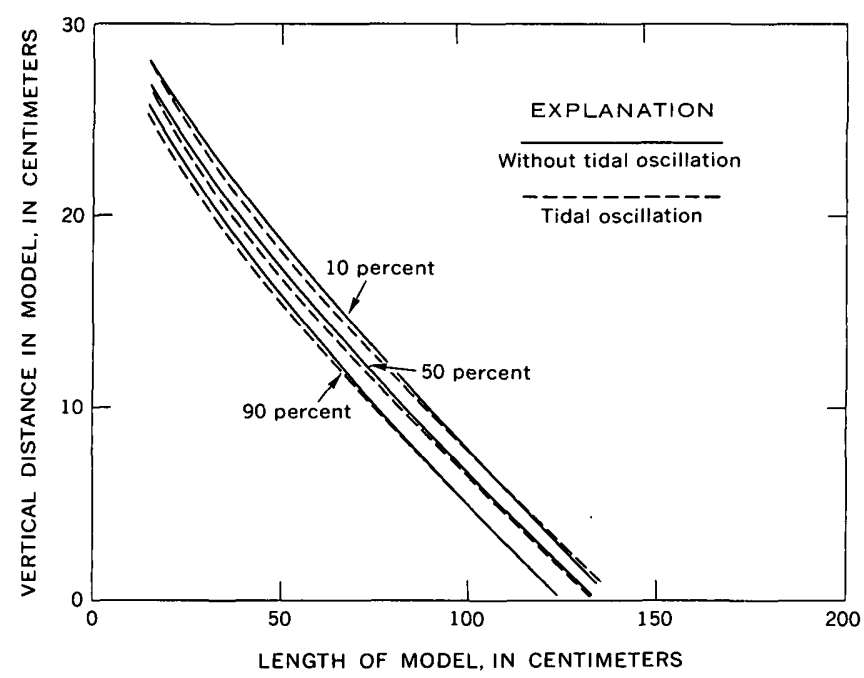

Figure 7.-Salt-water concentration profile at fresh water-salt water interface for steady and unsteady flow.
The dashed lines on figure 7 show the concentration distribution for the oscillating system with full fluctuation amplitude of $1 \mathrm{~cm}$. These readings were taken at the midpoint of an oscillation cycle after a given time of oscillation so that a good average was attained. The oscillation was about the mean head established in the steady-flow model. For the oscillating condition, a 14-percent salt concentration was detected in the effluent. Thus the effect of tidal fluctuations increases the salt-water flow back to the ocean, but does not change significantly the equilibrium profile of the dispersed zone.

The interface location for an intrusive salt-water wedge in equilibrium has been presented by Rumer and Harleman $(1963$, p. 200) as:

$$
y_{i}=\left[2\left(\frac{q_{f}}{K \frac{\Delta \rho}{\rho}}\right) x+0.55\left(\frac{q_{f}}{K \frac{\Delta \rho}{\rho}}\right)^{2}\right]^{1 / 2}
$$

where

$$
\begin{aligned}
y_{i}= & \text { distance from top of aquifer to salt water-fresh } \\
& \text { water interface, } \\
q_{f}= & \text { fresh-water flow per unit width of ocean front, } \\
K= & \text { permeability of the porous medium, } \\
x= & \text { distance from ocean to wedge toe, } \\
\Delta \rho= & \text { difference in density between salt and fresh } \\
& \text { water, and } \\
\rho= & \text { density of fresh water. }
\end{aligned}
$$

Computations based on the use of this dynamic mathematical expression were compared to data obtained from model results and shown as a solid line on figure 8 . The graph shows that, except for the region near the shoreline, the mathematical expression gives a good approximation of the dynamicequilibrium position of the 50-percent concentration line in two-fluid flow. The 50-percent concentration position was chosen because this concentration could be more accurately defined in the model.

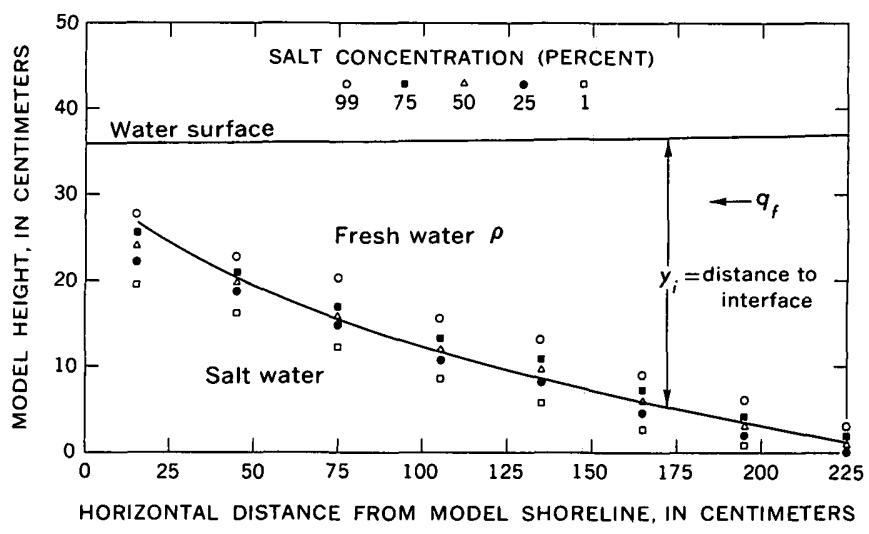

Figure 8.-Comparison of theoretical calculated values (solid line) and data obtained from model at the 50-percent concentration line in two-fluid flow. 


\section{CONCLUSIONS}

Laboratory studies of the two-fluid system reported here are preliminary. The in-place measurement required for study of any two-dimensional flow requires careful modeling techniques. The initial endeavor was towards development of satisfactory measurement techniques. Because a fixed probe left in the saline solution tends to change in characteristics, either a removable-probe technique or a method of $\backslash$ remote measurement is desirable. The method of inserting probe electrodes into the model proved satisfactory. The biggest disadvantage of the electrical probe is its effect on the microscopic flow system even for a short time because the probes are generally larger than the sand grains. Further investigation in the use of measurements of light transmission through the medium is also needed.

The use of a dye tracer in the model has a physical disadvantage in that most organic dye lags behind the carrier fluid because of adsorption. This becomes especially noticeable when typical ground-water flow velocities are used. However, in tests requiring only 2 or 3 hours for completion, the results obtained are generally satisfactory (Cahill, 1966). Because of the ease with which transmission of light through the models filled with glass beads can be measured and because of the possibility of obtaining measurements without disturbing the flow, this method is promising if suitable tracers can be found. Further tests are needed to evaluate this method, using various dyes, especially in recording the long-term characteristics and the possible use of adsorptionrate correction.

Because of the physical modeling difficulties, the investigation of miscible flow is still in its initial stage. Additional data for this system are needed for further studies, which should consider other mechanisms, such as pumpage and aquifer heterogeneity, that control the shape and position of the salt water-fresh water interface. More detailed investigations will be needed to include the boundary effects of pumpage and interior controls of aquifer heterogeneity and their effect on the transport mechanism. How these factors influence the dispersion process, which in turn governs the dynamic positioning of the two-fluid boundaries, must be assessed before mathematical formulation is possible.

Data obtained from these preliminary model experiments can be used to evaluate methodology and reproducibility. Agreement with published studies will determine to a large extent whether a valid method for the study of salt-water encroachment is available or if new methods need to be developed.

\section{REFERENCES CITED}

Abramowitz, M., and Stegum, A. S., 1964, Handbook of mathematical functions: U.S. Natl. Bur. Standards, Appl. Math. Ser. 55, 1046 p. Bear, Jacob, 1961, Some experiments in dispersion: Jour. Geophys. Research, v. 66, no. 8, p. 2455-2467.

Bear, Jacob, and Todd, D. K., 1960, The transition zone between fresh and salt waters in coastal aquifers: California Univ. Water Resources Center Contr. 29, 156 p.

Cahill, J. M., 1966, Preliminary evaluation of three tracers used in hydraulic experiments on sand models, in Geological Survey Research 1966: U.S. Geol. Survey Prof. Paper 550-B, p. B213-B217.

Cooper, H. H., Jr., Kohout, F. A., Henry, H. R., and Glover, R. E., 1964, Sea water in coastal aquifers: U.S. Geol. Survey Water-Supply Paper 1613-C, p. C1-C84.

Harlemann, D. R..F., and Rumer, R. R., Jr., 1963, Longitudinal and lateral dispersion :in an isotropic porous medium: Jour. Fluid Mechanics, v. 16, pt: 3, p. 385-394.

Kaufman, W. J., and Orlob, G. T., 1956, An evaluation of ground-water tracers: Am..Geophys. Union Trans., v. 37, no. 3, p. 297-306.

Radio Corp. of America, 1964, Photocells, solid-state photosensitive devices: Radio Corp. of America, Electronic Components and Devices, Harrison, N.J., 35 p.

Rumer, R. R., Jr., and Harleman, D. R. F., 1963, Intruded salt-water wedge in porous media: Am. Soc. Civil Engineers Proc., Jour. Hydraulics Div., v. 89, no. HY-6, p. 193-220. 


\section{RECENT PUBLICATIONS OF THE U.S. GEOLOGICAL SURVEY}

(Books may be ordered from the Superintendent of Documents, Government Printing Office, Washington, D.C., 20402, to whom remittances should be sent by check or money order. Give title, series No., stock No. (shown in parentheses in this list), and catalog No. [shown in brackets])

Professional Papers

440-N-1. Data of geochemistry, sixth edition, Michael Fleischer, technical editor, Chapter N. Chemistry of igneous rocks-Part 1 , The chemistry of the peralkaline oversaturated obsidians, by Ray MacDonald and D. K. Bailey. 1973 (1972). p. N1-N37. 75k. (2401-00253) [1 19:16:440-N-1]

529-K. Atlantic Continental Shelf and Slope of the United StatesSand-size fraction of bottom sediments, New Jersey to Nova Scotia, by J. V. A. Trumbull. 1972. p. K1-K45. 55\&. (2401-2185) [I 19:16:529-K]

532. Cenozoic fossil mollusks from western Pacific Islands; gastropods (Turritellidae through Strombidae), by H. S. Ladd. 1972.79 p.; 20 plates. \$1.50. (2401-2133) [I 19:16:532]

582-C. Transverse diffusion of solutes in natural streams, by Nobuhiro Yotsukura and E. D. Cobb. 1972. p. C1-C19. 55k. (2401-2147) [I 19:16:582-C]

585-A. Hydrologic investigations of prairie potholes in North Dakota, 1959-68, by W. S. Eisenlohr, Jr., and others. 1972 p. Al-A102; plates in pocket. \$3. (24.01-2156) [I 19:16:585-A]

655-E. Soil-moisture and energy relationships associated with riparian vegetation near San Carlos, Ariz., by I. S. McQueen and R. F. Miller. 1972. p. E1-E51. 60ł. (2401-2055) [I 19:16:655-E]

685. Fossils from the Ordovician Bioherm at Meikelejohn Peak, Nev., by R. J. Ross, Jr. 1972.47 p.; 18 plates showing fossils. $\$ 1.25$. (2401-2048) [I 19:16:685]

690. Stratigraphy and origin of the Chinle Formation and related Upper Triassic strata in the Colorado Plateau region, by J. H. Stewart, F. G. Poole, and R. F. Wilson, with a section on Sedimentary petrology, by R. A. Cadigan, and a section on Conglomerate studies, by William Thordarson, H. F. Albee, and J. H. Stewart. 1972. $336 \mathrm{p}$. $\$ 8.25$. (2401-2186) [I 19:16:690]

702. Stratigraphy and structure of Middle and Upper Ordovician rocks in the Sedgwick basin and adjacent areas, south-central Kansas, by W. L. Adkison. 1972. 33 p.; plates in pocket. \$1.50. (2401-2148) [1 19:16:702]

710. Jasperoid in the United States-Its characteristics, origin, and economic significance, by T. G. Lovering. 1972 . 164 p. $\$ 1.75$. (2401-1218) [I 19:16:710]

724-A. Huntington Lake quadrangle, central Sierra Nevada, Calif.Analytic data, by P.C. Bateman and D. R. Wones. 1972. p. Al-A18. 55k. (2401-00226) [I 19:16:724-A]

729-C. Stratigraphic framework of the Absaroka Volcanic Supergroup in the Yellowstone National Park region, by H. W. Smedes and H. J. Prostka. 1972. p. C1-C33. 50k. (2401-2151) [I 19:16:729-C]

746. Cenozoic rocks of the Santa Rita Mountains, southeast of Tucson, Ariz., by Harald Drewes. 1972. 66 p. \$1.50. (2401-2187) [I 19:16:746]

761. Geochemical anomalies and alteration in the Moenkopi Formation, Skull Creek, Moffat County, Colo., by R. A. Cadigan. 1972. 21 p. 70k. (2401-00221) [I 19:16:761]

762. Instrumentation studies of earth tremors related to geology and to mining at the Somerset coal mine, Colorado, by F. W. Osterwald, C. R. Dunrud, J. B. Bennetti, Jr., and J. 0. Maberry. 1972. 27 p. 70k. (2401-00227) [I 19:16:762]

795. Lower Cretaceous, Jurassic(?), and Triassic Ostracoda from the Atlantic Coastal region, by F. M. Swain and P. M. Brown. 1972. 55 p.; 9 plates. $\$ 2.00$. (2401-00250) [I 19:16:795]

796. Structural and stratigraphic framework, and spatial distribution of permeability of the Atlantic Coastal Plain, North Carolina to New York, by P. M. Brown, J. A. Miller, and F. M. Swain. 1972. 79 p.; text and plates in case. \$50. (2401-00243) [1 19:16:796]

800-D. Geological Survey Research 1972, Chapter D. 1972. p. D1-D227. \$4.50. (2401-00255) [I 19:16:800-D]
Bulletins

1331-A. Mississippian stratigraphy of northwestern Pennsylvania, by G. R. Schiner and G. E. Kimmel. 1972. p. A1-A27. \$1.25. (2401-2169) [I 19:3:1331-A]

1336. Precambrian geology of the northern Bradshaw Mountains, Yavapai County, Ariz., by C. A. Anderson and P. M. Blacet. 1972. 82 p. \$2.75. (2401-2101) [I 19:3:1336]

1340. Geology of the Moxie pluton in the Moosehead Lake-Jo-Mary Mountain area, Piscataquis County, Maine, by G. H: Espenshade. 1972. 40 p. \$3. (2401-2113) [I 19:3:1340]

1355. Placer gold deposits of Arizona, by M. G. Johnson. 1972. 103 p. $\$ 1 .(2401-2155)$ [I 19:3:1355]

1360. Geochemistry and diagenesis of tidal-marsh sediment, northeastern Gulf of Mexico, by V. E. Swanson, A. H. Love, and I. C. Frost. 1972. 83 p. 55 k. (2401-2093) [I 19:3:1360]

1363. Underclay deposits of Somerset and eastern Fayette Counties, Pa., by J. W. Hosterman. $1972.17 \mathrm{p}$; plates in pocket. $65 \dot{\phi}$. (2401-2155) [I 19:3:1363]

1364. Arsenic as an indicator element for mineralized volcanic pipes in the Red Mountains area, western San Juan Mountains, Colo., by W. S. Burbank, R. G. Luedke, and F. N. Ward. 1972. 31 p. 25 . (2401-2195) [I 19:3:1364]

1371-B. Mineral resources of the Salmon-Trinity Alps Primitive Area, Calif., by P. E. Hotz, H. K. Thurber, L. Y. Marks, and R. K. Evans, with a section on An aeromagnetic survey and interpretation, by Andrew Griscom. 1972. p. B1-B267. \$3.75. (2401-2199) [I 19:3:1371-B]

1371-C. Mineral resources of the Cloud Peak Primitive Area, Wyo., by T. H. Kiilsgaard, G. E. Ericksen, L. L. Patten, and C. L. Bieniewski. 1972. p. C1-C60; plates in pocket. $\$ 1.75$. (2401-00219) [I 19:3:1371-C]

Water-Supply Papers

1532-G. Hydrology and effects of conservation structures, Willow Creek basin, Valley County, Mont., 1954-68, by D. G. Frickel. 1972. p. G1-G34. 30k. (2401-02210) [I 19:13:1532-G]

1542-B. Accuracy of low-flow characteristics estimated by correlation of base-flow measurements, by C. H. Hardison and M. E. Moss, with a section on Outline of derivations by E.J. Gilroy. 1972. p. B1-B55. 40k. (2401-2168) [I 19:13:1542-B]

1586-J. Tracer simulation study of potential solute movement in Port Royal Sound, S.C., by F. A. Kilpatrick and T. R. Cummings. 1972. p. J1-J27. 55t. (2401-2196) [I 19:13:1586-J]

1798-J. Sediment transport in the western tributaries of the Sacramento River, Calif., by B. L. Jones, N. L. Hawley, and J. R. Crippen. 1972. p. J1-J27. 25k. (2401-2163) [I 19:13:1798-J]

1873-D. Measurement of salt-wedge excursion distance in the $\mathrm{Du}$ wamish River estuary, Seattle, Wash., by means of the dissolvedoxygen gradient, by W. A. Dawson and L. J. Tilley. 1972. p. D1-D27. 25k. (2401-2166) [I 19:13:1873-D]

1873-F. Determination of mass balance and entrainment in the stratified Duwamish River estuary, King County, Wash., by J. D. Stoner. 1972. p. F1-F17. 30\&. (2401-00252) [I 19:13:1873-F]

1999-N. Quality of the ground water in basalt of the Columbia River Group, Wash., Oreg., and Idaho, by R. C. Newcomb. 1972. p. N1-N71. 75k. (2401-2149) [I 19:13:1999-N]

2009-A. Runoff characteristics of California streams, by S. E. Rantz. 1972. p. Al-A38. 70k. (24.01-00216) [I 19:13:2009-A]

2025. Glossary of selected terms useful in studies of the mechanics of aquifer systems and land subsidence due to fluid withdrawal, by J. F. Poland, B. E. Lofgren, and F. S. Riley. 1972. 9 p. $15 t$. (2401-00228) [I 19:13:2025] 
POSTAGE AND FEES PAID

PUBLIC DOCUMENTS DEPARTMENT

U.S. GOVERNMENT

WASHINGTON, D.C. 20402

OFFICIAL BUSINESS

PRINTING OFFICE

PENALTYY FOR PRIVATE USE \$300

375 